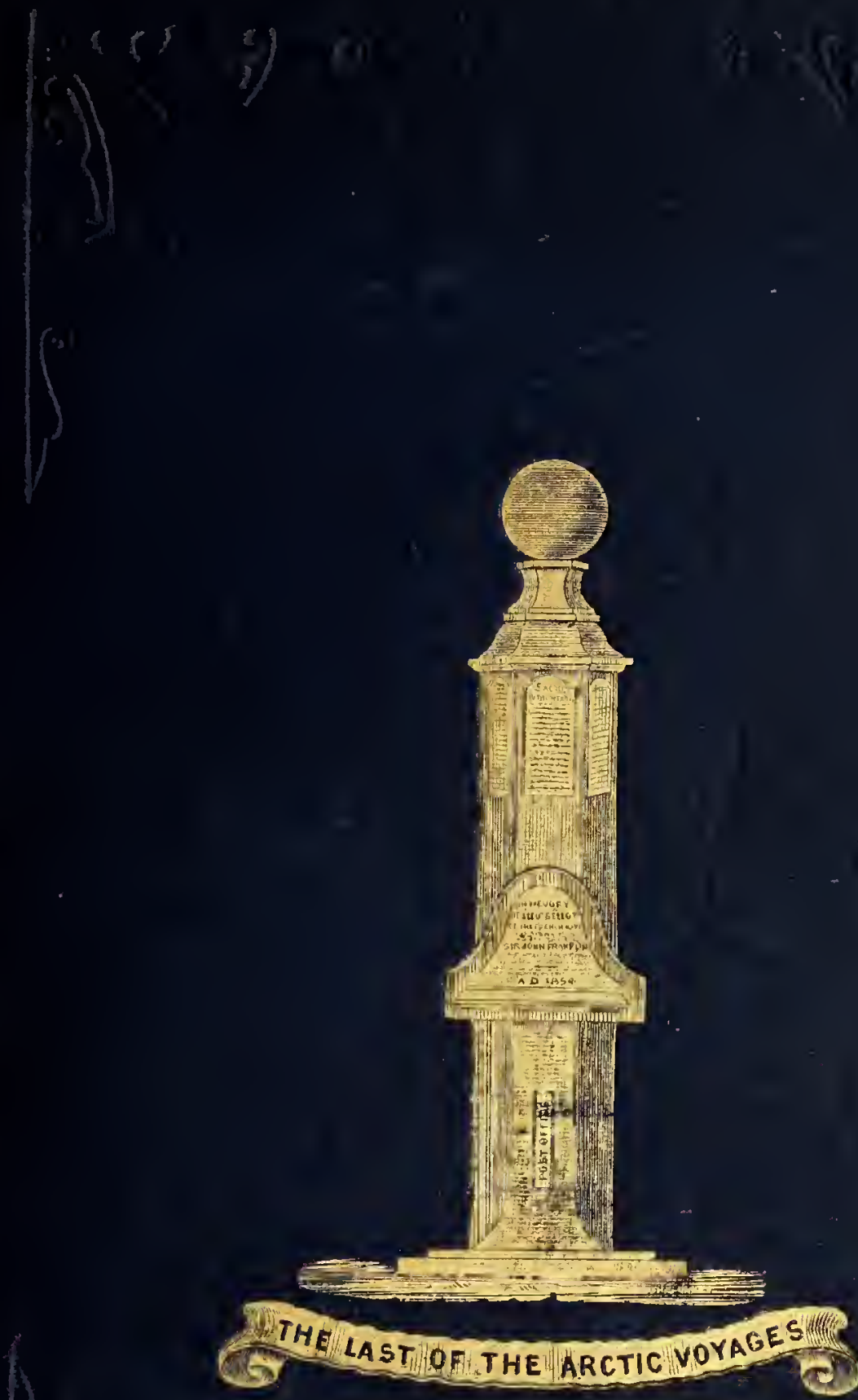




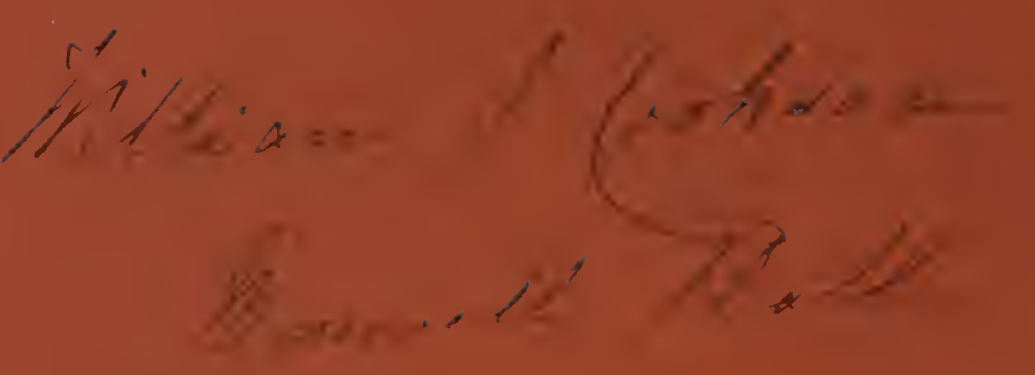

$$
\begin{aligned}
& 14.16
\end{aligned}
$$


Marine Biologíal Laboratory Library Woods Hole, Massachusetts

\section{WOYAGES - OF - EXPLORATION}
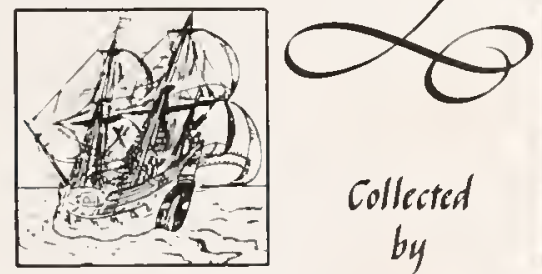

Collected

by

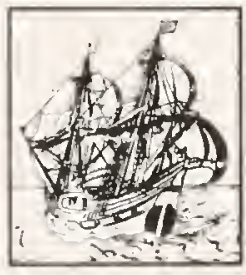

Newcomb $\mathcal{T}_{\text {hompson }}$ Montgomery (1907-1986)

Philadelphia architect, nephew of Thomas Harríson Montgomery (1873-1912), MBL imvestigator, and Priscilla Braislín Montgomery (1874-1956), MBL librarian.

Gift of thair sons Fugh Montgomery, M.D. and Raymond $B$. Montgomery -1987 . 
THE

LAST OF THE ARCTIC VOYAGES. 




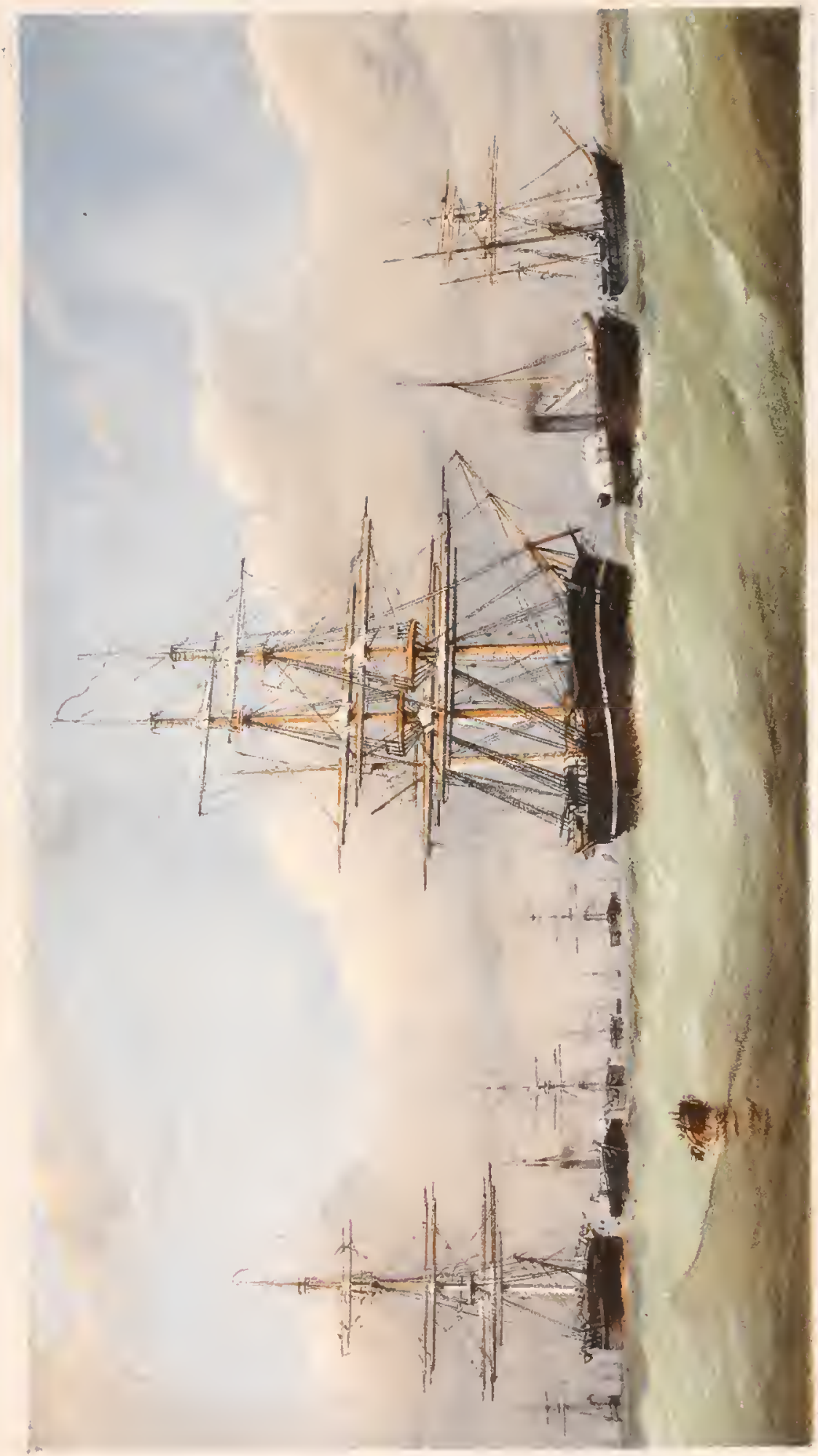


THE

\section{LAST' OF TIIE ARCTIC VOYAGES;}

BEING A NARRATIVE OF

THE EXPEDTTION IN H.M.S. ASSISTANCE,

UNDER THE COMMAND OF

CAP'TAIN SIR EDIVARD BELCHER, C.B.,

IN SEARCH OF SIR JOIN FRANKLIN, DURING TIE

FEARS 1552-53-54.

WITH

NOTES ON THE NATURAL HISTORY,

BY

SIR JOIN RICHARDSON, PROFESSOR OWEN, THOMAS BELL, I. IV. SALTER, AND LOVELL REEVE.

IN TWO VOLUMES.

TOL. I.

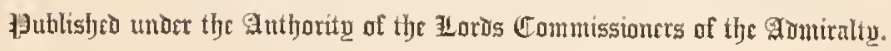

LONDON:

LOVELL REEVE, 5, HENRIETTA STREET, COVENT GARDEN.

1855. 


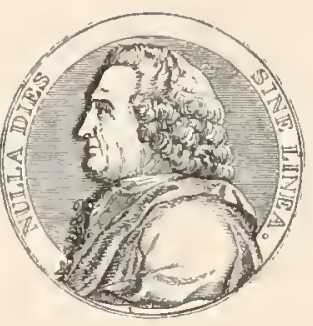

TOIU EDWARD TAYLOH, PIINTER,

LITTLE QUEEN STREET, LINCOLN'S INN FIELDS, 
REAR-ADMIRAL SIR FRANCIS BEAUFORT, K.C.B..

$$
\text { F.R.S., F.G.S., F.R.A.S., ETC., }
$$

THE HYDROGRAPHER OF THE AUMGRLTY,

TNDER WHOSE

GENEROUS SYIPATHY AND UNFLINCHING PATRIOTISM

THE VARIOUS EXPEDITIONS EXgaged IN SEARCH OF

SIR JOIN FRANKLIN AND HIS GALLANT ASSOCIATES

HAVE BEEN CHIEFLY PLANNED AND EXECUTED,

\section{This Narratífe}

of

THE LAST OF THE ARCTIC VOYAGES

IS (BT PERMISSION)

WITI FEELINGS OF RESPECT AND GRATITUDE

DEDICATED

BY HIS VERY FATTHFEL FRIEND ANI ADMTRER,

THE ATTHOR. 

PREFACE.

Tue details of Aretic Exploration, inelnding wintering and sledge-travelling, having been so fully deseribed by preeeding voyagers, my object in presenting to the public, the following narrative lias been rather to plaee on reeord an account of the Expedition of H.M.S. Assistanee, as bcing 'The Last of the Aretic Voyages' undertaken by this eountry in search of the lost Franklin, and as being that which penetrated up Wellington Chamnel to the cxtreme limits of navigation. The Title of the work may appear open to objeetion, but taking into aceount the dates of original Orders, and those in foree in April, 1854, it will be apparent that the final command of the British Naval Expcdition within the Arctie Scas was vested in me. That I eonceived aright the intent of my Instructions, the probabilities attending the safety of other branehes not aeting immediately under my control, has been sufficiently verified by the safe return of all engaged, to this eountry.

Reecnt accounts affording the satisfaetory intelligence 
of the rclease of the American Expedition adds another proof of the uncertainty of the navigation even of the mouth of Lancaster Sound, which was found late in Augnst to be complctcly barred by ice; and conscquently Captain Hartstcin was mable to placc the monument to Captain Franklin on Becchey Island. With such facts before us, we cammot but rejoice that no resscls and crews were left, to distract the feclings of rclatives nor nselessly to exlaust the revenues of the country.

The system of Aretic travel by sledges over vast distances, and the powers of men in carrying out labours under which the quadruped, taking man- against horsepower, would succumb, present a new fenture as compared with the labours of the lamented Parry and his associates. True it is that the qualitics of the professed seaman find but small scope in this narrative; bnt the cxertions of those who did renture upon travel offers matter for reflection on the powers of men in every stage of action where their serviees may be required, be the cnemy frost, fire, patient cndurance of monotonous labour, or battle.

The value of the seaman-I mean the disciplined man -in carrying out the service here recorded, entailing questions even of existence if they faltered or failed in strength, lias not, I fear, becn sufficiently estimated by those who merely read of the exploits of the sledge travellers; nor can my pen do justice to their labours, to the passive endurance, the ligh discipline, which characterized their performance, only to be sustrined on the 
lonneward route under the conviction that failure wonld entail the most eruel deatl.

Unwittingly we allot the eredit to the officers; but, as one of those traveller's who entered most fully into the feclings of the men, their habits and prejudices, aud free from the killing labour of the drag-rope, my dinty eompelling me to stop labour when I perhaps felt quite able to endure more, I do eonscientiously assert that the greatest credit is due to the fine moral erew which it was my good fortme to eommand, and to return to this country without even the threat of the lash. What has bcen their reward? 'l'le exeitement of war possibly has blinded their eountrymen to their deserts; or Aretic service, now that scarch has terminated, is eclipsed by labour in the trenehes.

'Thus mueh then for Aretic serviee. Next will be found mattcrs eonnceted with seienee, whieh, although treated of in the carly history whieh broke gromud through Laneaster Sound in 181S-19-20, still left us in doubt as to the general laws which prevailed over a series of years,--indeed did not afford any deeided data on whieh argument eould be founded, as to the mean temperatures of months or seasons, nor of the ratio in which the freezing of the winter ice covering those scas proeeeds. Nor do I pretend to have determined these questions; but mercly in prodneing possibly the most perfect eollcetion of such records, and, as an observer on the spot, furnishing sueh ideas as foreed themselves on my mind, afford to those more deeply versed in metcoro- 
logieal questions data on whiels they may build more reliable theories than prevailed previous to this Expedition.

Another question, and one not unattended by opportunity for eavil, may be found in the measures which were adopted by me for the preservation of the health of nyy erew, as well as the comfort between deeks; but on all these matters I think that figures and facts must drown all eavil, and that in any future fittings the system advoeated and proved by me must lave foree in a sanitary point of view. The deatlis whieh ocenred were elearly those whieh might have been avoided by a more striet attention to the seleetion of the individuals; none eould be elassed as the result of Aretie travel or exposure.

Other matters, embraeing periodie retums of gales, bad weather, and unaecountable disruption of the ice after winter had apparently set its seal on the season, offer subjects for interesting diseussion. The effect of contrary tides, meeting as they do in this country about Dover, point out unmistakably the reason that Vellington Channel remains sealed at the very moment that nature appears to promise its free navigation.

One only question remains in mystery, that is the final report as to the fate of the gallant Sir Joln Franklin and his companions. I have treated that with the same confidenee which indueed me to assert, in August, 1852, " that he never passed northerly or westerly of Becehey Island ;" and, mtil positive intelligenee to the eontrary 
reaches us, must yet believe that his parties divided as I have imagined.

Although I lave not in these pages asserted any elaim to the participation in the solution of the Northern Passage to the Paeifie, still any geographer will readily understand that the continnous frozen sea, traeed by the officers under my eommand, in 1553, proves a water communieation through IVellington Channel, round Parry Islands, to the position attained hy Captain M'Clure; and that in 1854 our sledge-parties had penetrated to the southern extreme of Prinee of Wales Strait, perfeeting the labours of Dease and Simpson.

I am indebted to Sir Jolm Richardson, Professor Owen, Professor Bell, Mr. Salter, Mr. Glaisher, and Mr. Recve, for their valuable eontributions to the Natural Ilistory portion of the seeond volume. Eacl statement offered is supported by doeuments, aeessible to any who may be desirous of further evidenee.

To those who have seeonded and supported me in my duties, whether named or otherwise, my thanks are due; and I thus express myself beeause I know it will be neeptable to those who lionestly performed their duty: "Palmam qui meruit ferat."

Edward Belcher.

London, Norember 1, 1555. 


\title{
$10 \mathrm{~N}$ T E N T'S
}

\author{
OF VOL. I.
}

\section{PRELIMINARY.}

Armiralty Instructions.-List of Offieers.-The 'North Star.'Toat Iepartment. - Supplies.-Instruments.-Azinuth Tibles. -Library and Printing Press._-Ships Undoeked._Leare Woolwich.-Visited by the Admiralty, -Quit the Nore . . . .

\section{CHAPTER I.}

It Sen.-Reach the Orkneys.-Stromness.-Senreity of Stock.Departure of the 'Basilisk' and 'Desperate.'-Enter Baflin's Bay.-Whalefish Islands.-Reeeption by Esquimaux.-Licrely. - Tisasters.-Moored at Licrely. Surrey of the l'ort.-Quit Lievely.-Search for Coal.-Quit the Waigat . . . . . 2:

\section{CHAPTER II.}

Anchor at Upernarik.-The Squadron adrift.-Dangers numcrons.-Prospects of the Voyage-- Browne Islands.-Preparation for Flitting.-The 'Resolute' nipped.-Docking.--Blasting Ice.-Wreek of the 'Regalia.'-Meet a Whalcr.-Irregulinitics of the Crew.-Melville Bay.-Floe Law.-Capture a Bear-Cape Tork . . . . . . . . . . . 42

\section{CHAPTER III.}

Natire Dogs.-Red snow.-Cape Dudley Digges.-Game.-Cape Warrender.-Beechey Island.-Rejoined by Captain Kellett.Cape Riley.-Find Pieces of Whalc.-Parting Ccremonies.Wellington Chamel. - Queen's Channel. Count Percy.Winter Quarters . . . . . . . . . . . 
CHAPTER IV.

Frozen in.-Sledge Trarelling.-Walrus Shot.-Tabits of the Vahus.-Village Point.-Esquimanx Hut.-Deceived by Mirage.-Tent Equipage.-The Sentinel.-Iec Accumulations.An Intruder.-Exmouth Island.--Rejoining of the Party.-Nip and Piling lee.-Quit Exmouth Island.-North Cornwall . 90

\section{CHAPTER V.}

Retreat.-Land's End of North Conwall.-Pell Point.-Table Island._Chased by a Walrus.-Sledge breaks in.-Danger from the Ice.-Observatory erected.-Seeond Autumnal Expedition.- Traces of Gold.-Gale and Distuption of Iec.-Oomiak construeted.-Wahns food.-The 'Eider-duek.'-Gain the Land-iee.--Reach Point Repose.-Return to the Ship . . . 113

\section{CHIPTER VI.}

The 'Assistance. - Winter Fittings.-Moisture between Deeks. -Meteorological Investigations.-Tide Gauge.-Anatomieal Shrimps.- I Tashhouse.-Thoughts on Aretic Fittings.-Terraced Levels. - Effeets of Tidal Aetion.-Tidal Fissures.-Experiments on Iec.-Last View of the Sun.-Her Majesty's Arctie 'Theatre. - $\Lambda$ Gale.-The Observatory. $-\Lambda$ Snow-storm 137

\section{CHAPTER VII.}

Transit Teleseope.-Extremes of Cold.-Effeets of the Gale.Remarks on Equipment.-Scnsations of Cold.-Paraselena.Sehools Established.- - Society of Loyal Aretic Engineers.Defleetions of the Magnetometer.-Experiments on Freezing. -Iee Crystals.-The Aurora . . . . . . . . . . . 15 s

\section{CHAPTER V11I.}

Short Days.-Minimum Temperatures. - Warmth of Vessels. $-\Lambda$ She-Bear.-Preparations for Travel.-Theatrieals.- Shortest Day.-Christmas Ode.-Christmas Fare.-Depth of Winter. - The New Fear.-Comparison of Thernometers.-Freczing Merenry.-Range of Extreme Cold.-Freezing Ale.-Aleohol at a low Temperatmir . . . . . . . . . . 181 


\section{CHAPTER IX.}

Rise of Temperature. $-\Lambda$ Bear shot.-Termination of Darkilless.

-Re-appearanee of the Sun.-Death of a Marine.-Cold Period of March._- Table of Temperatures._A She-Bear and her Cllbs. - Sledges inspeeted. - leet Wrappers.-Departure of the Sledges.-Theacons.-Cairns.-Parhelia.-Inland Exeursion.Wrary Iee.-Cooking Apparatus.-Laups.-Return of Depôt Dirision

\section{CHAPTER X.}

The Cairn.-Antieipations. - South-west Expedition.-Tidal Motions.-Return of Mr. Loney.-Dog Killed.-Letters from Pullen. - North-east Expedition. - Tent Arrangements. - A Cold Bath.-The First Depôt.-A Wolf.-Princess Royal Island.-Tidal Rents.-Snow Blinduess.-Mount Parker.-A Whalc.-Hamilton Depôt . . . . . . . . . . 240

\section{CHAPTER XI.}

Inconvenient elevation.-Cape Disraeli.-Imbedded Whale.Departure of Mr. Allard.-Determination of speed.-Strait discovered.--Progress arrested by the Paek.-Sirow Crystals. -Diseover open water.-Orerland mareh.-Progress barred.Fossil Station.-Deep Somdings.-Paek Ice.-A hollow Cain. - Cape Disappointment. - Mellington Chamel. - Apparent Grares.-Piteh Momut.-Bears . . . . . . . . 264

\section{CHAPTER XII.}

1 lamilton Depôt.-Monut Parker.-Patehes of Water.-Muskoxen.- Dr. Lyall and Mr. Hllard rejoin. - Preparations for seareh Northwards. - Lost Dog.-Freaks of Refraetion.-Westcru Island.-Effect of Snn's Heat.-Buchinghan Island.-Scalholes. - Bear-hunt. - Recovery of Sledge. - Watercourses.Rounded Pebbles. - Surface Distmbances. - Cape Ogle. II ater-fowl.-Lemmings.-Star Bluff.-Return to the Ship . 297

\section{CHAPTER XIII.}

Open Water.-Despateh from Richards.-Notiee left by M'Clure. -Stores eorered with Snow.-Brewing.-Mustard and Cress. 
- Return of Richards.-Movements of Western Division.Fame killed.-Canal completed.-Cairn on Barrow Island.Osborn rejoins.-Mount Acland--Assistance Spit.-Visit of Pullen.--Port Refuge . . . . . . . . . . . 329

CHAPTER XIV.

First symptom of Winter.-Alarming Discovery.-Suspicions awakened.-Escape from a Nip.-Recent fragment of a Ship. - Drift-wood.-Party for Beeclicy 1sland.-Despatch of Licutenant Osboru.-Want of Steam-power.-Unsafe position.Lid sent to Licntenant Osborn.-Inland Lakes.-Fishing.-A Spar found.-Trunk of a Trec.-Disturbance of the Ice.Fragments of a Ship . . . . . . . . . . . 367 


\section{FLOSSARY OF ARCTIC TERUS.}

Anchor, lce, a round bar of iron twice bent like a pot-look: the end to which the rope is bent is cut short off and bent suddenly back: the other is tapered after the bend, which is at an angle of $60^{\circ}$ to the body or slink. 1 loole being eut in the ice by an axe fashioned for this purpose, similar to half a pickaxe, this hook serves to secure the vessel to the ice.

tie, Ice, als above described.

Barber is properly the condensation of vapour rising from ice, the result of freezing; also breath condensed.

Bay Ice, that which freezes continuously on tle surface, and derives its name probably from its forming more rapidly in bays, or spots sheltered from the brecze.

Beset, the approach of floating ice ou all sides, lcaving 110 opening for advance or retreat, and leaving the vessel unmanageable.

Bight, any hollow, bay of ice, land, ete.

Berg. Sce lcebery.

Blasting: this operation is generally performed by cutting a hole through the ice of sufficient bore to aduit of a canister of six inches diameter, containing powder, being passed through; a flexible fuse of sufficient length to burn three minutes being lighted, affords time to permit the men to recerle from danger.

Bore: to bore through the pack; the foreing a vessel through loose, wovable pack under canvas or steant, with the chances of taking advantage of cracks or openings.

Brash, comminuted ice.

Buckle, bending or arching of the ice upwards, preceding a nip. 
Calf, a huge splintcr splitting off from a berg, or the berg detaching itsclf from the main mass on which it formed ; sometimes misrcpresented by a shelf, or loose piece, which is driven from under the floe, and rises suddenly to the surface, damaging ship or boat.

Clear "I"ater, no ice obstructing navigation.

Crow's-nest, a watch-box constructed at the topgallantmast-head, to protect the man looking out for whales or ice from the inclemency of the weather; sitting eomfortably ensconced in the Crow's-nest, the Ice-master pilots the vessel through the best lanes or open places iu the icc.

Curl, the bending over or dismption of the ice at the point of resistance, causing it to pile slab over slab, or throw over the comminuted bits.

Cutting, out or in, performed by sawing canals, out of which the icc is lifted above, or passed beneath, the floe, enabling the ship to advance towards open water.

Dock: this is simply an opening cut out of the floe into which the ship is warped for security against threatened pressure, fiom extensive floes coming into opposition. It is, as reason will point out, at right angles to any extensive erack or open water. $\Lambda$ "natural dock" is frequently afforder by some deep gap, out of which, at some of these convulsions, the ice has floatcl. Any extensive floe falling across the mouth of such an opening would naturally close it, expending its force on the projecting irregularities.

Field Ice, any great extent of smooth ice, the result of water frozen in a quiescent condition, and of equal thickness throughont.

Floe may be any portion of a field of icc disconnected, as thoe piecs. Bay floe, or Land floe, would be that attached to the land. Bay floe is also considered as bay ice of the last season, now become floc of the present.

IInmmocks, lumps of ice, generally bits of pack frozen together, and snow covered lluring winter.

Ice. See Bay Ice, Field Ice, Floe, Pach, Pancake Ice.

Ice Anchor. See Anclior.

Ice Axe. See Axe.

Iceberg: this term is fiequently misapplied; properly it belongs only to huge mountains of ice entirely of fieshwater formation, which 
by constant increase from the summer thaws become at length too heary to be supported by cohesion to the land mass, and then calve, or split off from the glacicr. They are termed by the Greenland authorities (vide Grah, p. 24) Icc Blinks.

Ice Blink: this term, as understood by our Grecnland whalers, does not bear the same meaning as that giren by the Danes. With us "blink" indicates the reflection in the atmosphere over the object. The term in the Euglish dictionary defines it, "to glisten, show white," ctc. If the atmosphere immediatcly over the olject bc charged with vapour, its image may be perfectly reflected or represented, or, when very distant, a whitish amroral divergence of rays constitutes the blink, seen long before the object itself can be distinguisherl it is comparatire with onr "loou of land."

Ice Chisels, large socket chisels, into which poles are inserted, used to cut holes in the ice.

Ice Ilooks, ol Clares, similar to timber claws; a donble hook, with lectangular poiuted claws to hold on by abrupt ice or cracks.

Ice Master, or Ice Quartermaster; a whaling captain or mate, selected for his experience in the whalc-fislery, to afford advice to the officers commanding. He nsually pilots the ressel either from the Crow's-nest, or spike plank, when amongst the ice.

Ice Plank, or Spike Plank, a platform projecting across the ressel seven or eight feet above deck and beyond the sides, to enable the pilot to run from side to side, to pilot the ressel clear of ice.

Ice Sans, huge saws made from half-incl plates of iron, and varying in length from ten to twenty-four feet.

Ice Sludye, smaller comminuted ice, or bay ice broken up by the wind.

Lane, any open cracks, or separations of floe, oflering navigation.

Lead, similar to Lane.

Nip: when two floes are in motion and approaching cacl other, the result generally is a grinding action in passing or until their intpetus is expended, which destroys the opposed surfaces, laising long ridges of curled or thrown-up ice. When a ressel unhappily has not time to dock, or becomes entrapped between the opposed bodics, she becones nipped, or, in many cases, the tloe, which is weakest, rises over and orerwhelms her cntirely, - to use the whaler's term, "walks clcan over her."

Vot. I. 
Old Ice, that of previous seasons.

Pack is that collection of broken floe which, huddled together mder pressure, is constantly varying in its position; it cannot be dealt with nor can it be travelled over nntil cemented together by freezing; it has no linit,--it may corer a mile or hundreds of miles, as in Baffin's Bay. Simply it is any loose ice packed into a space before vacant.

Puncule Ice, that which results from snow falling into the sea without thawing, and by the action of the waves driven into pancake forms, which offer no solid obstruction, but nevertheless hamper a vessel more than sinall ice.

Reeving, following up rarious labyrinthine or angular channels until the ressel reaches open water" as, "reeve the pack."

Run, when the ice is suddenly impelled by an unaccountable, fitful, rushing motion.

Sailing, loose ice relieved from pressure, which admits of picking a way throngh the weakest parts.

Shearing, or Lapping: this applies more peculiarly to young or thin ice with boats, one plate orerlapping another where a boat has made an extensive crack. Where boats have been thus destroyed the crews have rarely escaped, the ice being too weak to bear, and the plates orerlapping those attempting to swim.

Shelf, or Tongue: frequently, on the meeting of adverse floes, a smaller interposing floe-piece is forced under, and, cohering or freezing to that above, presents, below water, a tongue or shclf, which ammoys the keel of a vessel, or, breaking off, comes up as a "calf" with great violence.

Sludge, comminuted ice.

Smoke, or Vapour, a peculiar kind of vapour, the natural result of the conversion of water into ice, which is constantly supposed to indicate lakes or open water in an unfrozen state.

II ater Sky: this evidently is comrected with smoke or valpour, and is the reflectcd colour of the blue sea in the atmosphere or vapour arising from the warmer sea; it generally exlibits a dark, dull, neutral tint, which is never seen to the eye, at least of an intelligent ice-master, unless wuter be under it. This is peculiarly the case in Melville Bay.

Foung Itr, that immediately formed, or of the present season. 


\section{I S T}

or

CHARTS, PLATES, AND WOOD ENGRAVINGS.

\section{Charts.}

1. Discoveries in the Arctic Sea, 1819-54 Vol. I. In pocket.

$\checkmark 2$. Plan of the Port of Lievely . . " ib.

—3. Plan of Northumberland Sound . . " Page 90

4. Plan of the Fossiliferons Oval . . Vol. II. 391

\section{Jlates.}

1. Aretic Squadron quitting the Nore

Vol. I., Frontispiece.

2. Extraordinary Dyke, Point Hogarth

Page 85

3. Novel Ferry

" 93

4. Exmouth Island . . . „ „ „ 105

5. The 'Hamilton' under canvas . . " " 119

6. Duck-shooting in Oomiak sledge . . " " 133

7. Snow wreath, Northumberland Sound . „ „ „ 155

S. Paraselena . . . . . . . , , „

9. Alarum Tide-gange . . . . " " 141

10. Departure of Sledges . . . . " „ . " 243

11. Entrance of Cardigan Strait . . . " " " 271

12. Blown out of Winter Quarters . . Vol. II., Frontispiece.

2 13. Crystal Palace Winter Quarters . . „ „ Page 67

14. Upper Deck Fittiugs . . . . " „ „ 291

15. Cenotaph at Beceliey Island . . . „ „ „ 231

16. Direetion Signals . . . . Vol. I. „ 350

$\checkmark$ 17. Thermometer buried iu snow . . Vol. II. „ 173

-15. Plan of Ooniak sledge . . . Vol. I. „ 131 
19 to 22. Illustrations of Snow Crystals 23 to 30 . Illustrations of Fish

31. Bones of Ichthyosaurus

32 and 33. Illustrations of Shells 34 and 35 . Illustrations of Crustacea

36. Illustrations of Carbouiferous Fossils
Vol. II. Appendix.

\section{VTrood Engrabings.}

Esquimaux huts

Vol. I. Page 95

Wooden flaying-knife . . . . "

lee cracks . . . . . . ",

Effects of tidal motion . . . . "

Aneroid incrusted with snow . . . "

Effects of gale on snow pillars . . . "

Hard-lined elouds . . . . . "

Mercurio-spirit thermometer . . . "

Thermometer vane . . . . . ,

Feet-wrappers . . . . "

Thermometer block . . . . "

Parbelia . . . . . . "

Rig of sledges . . . . . "

Upsetting of sledges and old ice . . . "

Princess Royal Island . . . . "

Hamilton Depôt . . . . " "

Fossil station . . . . . . " . . . .

Hollow cairn . . . . . .

Graves . . . . . . " . . " . "

Peculiar Cairn . . . . . "

Treaks of Refraction . . . . "

Star Bluff, Cape Ekins . . . . "

Driven aground-Riun of ice . . . Vol. II.

Coast-line fissures

Prismatie Cross

$\begin{array}{ll}\text { " } & \text { " } \\ \text { ", } & , \\ \text { ", } & ,\end{array}$

2109

\# 149

" 157

162

169

207

, 212

, 221

,$\quad 223$

, 227

, 229

, 231

, 258

, 263

$3 \quad 263$

1, 272

, 280

, 285

291

" 303

, 325

" 325

," 57

73

" 92
, 97 


\title{
LAST OF THE ARCTIC VOYAGES,
}

\author{
UNDER THE COMMAND OF \\ CAPTAIN SIR EDWARD BELCHER, C.B.
}

\section{PRELIMINARY.}

Admiralty Instructions.-List of Officers.-The 'North Star.'-Boat Department.-Supplies.-Instruments.-Azimuth Tables.-Library and Printing Press.-Ships Undocked,-Leave Woolwich.-Visited by the Admiralty.-Quit the Nore.

Her Majesty's Government liaving deemed it necessary to prosccute the further scarch for the 'Erebus' and 'Terror,' which left England in the month of May, 1845, as wcll as for any traces of Sir John Franklin or his followers, my Lords Commissioners of the Admiralty were pleased to entrust me with the command of the Expedition, the entire objects of which will be nearly apparent from the following Instructions :-

$$
\text { ORDERS.-No. I. }
$$

By the Commissioners for executing the Office of Lord High Admiral of the United Kingdom of Great Britain and Ireland, etc. etc.

1. Having appointed you to the command of the Expedition (to consist of the ships named in the margin*) preparing for the further

* Assistance, Resolnte, Pioneer, Intrepid, North Star.

VOI, I, 
search for Sir John Franklin, you are, whenerer such ships sball be in all respects ready to put to sca and proceeding down Channel or " north about," make the best of your way to Barrow Strait, calling at Disco (if in your way) for such replenishments as the place affords, and for a supply of $\log$ s for slectging purposes.

2. We have entristed you with this command in the full persuasion of your thorough aequaintance with its obligations, and of your judgment and ability to neet them.

3. The do not therefore consider it necessary to encumber you with minute instructions for your guidance at each step of your proceedings; but fmrnishing you with papers which point ont the views of the Adminalty, as successive expeditions have been despatched from this comntry, and those also relative to the difficulties occurring to oppose those views, we leare it to you to decide as the case shall present itself.

4. Te deem it right, however, that a certain course of proceedings should be pointed out to you; and adopting the recommendation of the Committee appointed in October, 1851, to inquire and report upon a previons expedition, the plan of future operations there proposed is to be considered as the basis of your proceedings. By that plan, Beechey Island is the point indicated as the basis of your operations, and you are to consicler it as the grand rendezvons to which yon are to push forward, there to establish the "North Star' as a gencral depôt.

5. Arrived at this point, two great objects will engage your attention :-

1st. The endearoming to pass up Wellington Chamel with one sailing-ressel aud one steamer.

2nd. The adrance of a similar force towards Melville Island.

6. The object of the first of these expeditions will be, the endearour to recover those traces of Sil Joln Franklin which ceased at Cape Bowden, to the north of Beechey Island; and to follow up such traces if they should be found. The object of the other expedition will be, to deposit, if possible, at Winter Harbour, Melville Island, or failing that, at Byam Martin Island, a supply of provisions, fnel, and clothing, for any parties that might reach such positions from Captain Collinson's or Commander Mr'Clure's ships.

7. As regards the first-namerl Expedition, and the possible contingency of coming upon Sir John Franklin's track, we cannot too strongly impress upon yon the necessity of your establishing along your line of ronte cachettes of provisions sufficient to supply your crews and those of the missing ships, should any accirlent happen to your own 
vessels, and render it necessary for you to return without them to the general rendezrous at Beechey Island; and you will be most eareful along the line of such route, as well as in cvery ofler direction you may have to take, to avail yourself of every remakable promontory, point of land, or other distinctive locality, to deposit exaet notices of your condition and intenderl proceedings; and you are to give positive ordcrs that these notices or records are to be deposited ten fcet true north of the cairn or staff, and likewise beneath or in the cairn itsclf.

S. With regard to the Expedition to be despatched towards Melville Island, it is scarcely to be contemplated that, under the most favourable circumstances, more could be done in the first season than to reach that point; and the officer in charge of that service will of course have to take into account the having to winter in that quarter.

9. His earliest atteution in that case, in the ensuing Spring, will be, - Ist, the depositing such supplies at Melville Island as he can spare, or endeavouring to convey them thither by sledges if he should not reach the island with his ships; and 2nd, the detaching travelling parties in a westerly direction for the combined purpose of a search for traces of Sir John Franklin, and of depositing notices in conspicnons sitnations as to where the supplies are left, but being at the same time. strictly enjoincd to return to their ships before the usnal period of the breaking up of the ice, in order that such ships may return to their rendezrons at Beechey Island, or othcrwise preparc for quitting Lancaster Sound to return to England, aceording as the supplies on board of his ships and the length of time consumed in the above service shall require.

10. And here we think it necessary more particnlarly to call your attention to the instructions to be given by you to the officer charged with this branch of the Expedition; for whilst there is a possibility of your calculating on an carly return of sueh officer from Melrille Island in the summer of 1853 , and of lais being able to afford you snpport in any particnlar direction, it is, on the other hand, not improbable, that from a prolonged detention to the westward, it may be his bounden duty not to hazard a further stay in those seas, but to make the best of his way home; in which case he mnst endeavour to communicate with the rendezrous at Beechey Island before finally quitting Barrow's Strait, in order to obtain information of the other ships, and to deposit records of his proceedings.

11. He shonld therefore be made to nnderstand the natnre of the responsibility that devolves upon him, both as to the execution of his 
orders in the first instance, and determining the point at which the power of compliance with those orders censes.

12. It is of course possible that seasons such as werc expericneed by the Expedition in 1550-51 may again occur to prevent a passage by ships up Wellington Channel or to the west of Griffith Island; and, uncler such circumstances it will be for you to consider how far it might serve any useful purpose to undertake an examination by travelling parties from Baring Bay or l'rince Alfred Bay, in the direction of Jones's Sound; in addition to those which it will be yom duty to send ont to the north and north-west, for traces of Sir John Franklin, in the direction of Quecu's Channel.

13. Our instructions thercfore are withont reference to the possible circumstance of records still being found at Beechey Island or elsewhere (and for which it will be your duty to search), at a certain distance from the respective canns, where it has been stated it was Sir John Franklin's custom to deposit them ; *and if by snch records it should prove that sir John Franklin procceded to the eastward out of Lancaster Sound, after he wintered at Beechcy Island in 1845-46, you will still eontinue to push forward two of your ships towards Melville Island, as already directed by us, and with the other two you are to act as circumstances may render necessary, depending on the information which those records inay convey. And alverting to the report of two ships having been seen on the ice in the North Atlantic in the spring of 1851 , we think it experlient to draw yon attention to this subject, that you may adopt such steps on your way from Baffin Bay, with reference to scarch and inquiry on the shores of Davis Straits, as you may consider most advisable under the circumstances above stated, and the information the records may convey.

11. You are aware of the deposit of stores and provisions at Port Leopold, and of the stean-launch left there by Sir James Ross: you are at liberty to employ that ressel in any way that lee services may be made available; but with reference to the store of provisions at l'ort Leopold, and also those for one humdred men which were landed by Mr. Samnders on an island in Nary Board Inlet, it is our directions that such provisions and stores shall on no account be touched by any of the vessels under your orders, unless compelled to do so by absolute neressity.

* The piece of tin or copper, said by Adam Beck to have been dropped from a staff, should also be looked for.- See Evidence before the Arctic Committee. 
15. We have furnished yon with copies of these instructions, which you are to deliver to the Captain and Officers in command of vessels under your orders. And we deem it necessary that yon should be dirested to communicate freely and umeservedly with your second in command and the officers in charge of the other ships, on all points connected with the Expedition, keeping them acquainted with your riews and intentions, that, in case of an accident happening to yourself, or a separation of the ships, these officers may bc fully aware of the course of proceedings intended to be adopted by you; and when the ships are separated from you for the purpose of carrying out our orders, the sane unreserved intercourse and communication is to be maintained between the officers in command of the respertive ships.

16. You are no doubt aware of the 'Prince Albert,' prirate ressel, being engaged in a like search in the Arctic Seas; you are to aflord that ressel ercry aid and assistance, in the event of falling in with her, but you are in no way to interfere with her orders or take her under your cliarge.

1\%. The various logs and private jouruals, with drawings, plans, etc., are to be sent to this office on the return of the Expedition. And you are to be careful that, from the date of your parting company with the ships sent to assist in toming you, your own letters to our Secretary, together with those of the officers addressing you, are duly nmmbcred as well as dated; and you are invariably, should any opportunity offer; to leave letters for us at such places as Cape Warrender, Ponds Bay, etc., prorided no delay be incured thercly.

15. Tour ships have been fully equipped for the service they are going upon, and it has been om desire that you should be provided with erery means and resource that might be made available. We have an entive reliance on the best use and application of those means on your part, and we lave equal confidence in the care to be exercised by you for those employed under your orders; but there is one object which in the exercise of that care will naturally engage your constant attention, and that is, the safe return of your party to this country.

19. We are sensible howerer that notwithstanching a wish to keep this part of your duty prominently in mind, yet that an ardent desire to accomplish the object of your mission, added to a generous synpathy for your missing comitrymen, may prevail in some degree to carry you beyond the limits of a cantious prudence.

20. You are therefore distinctly to understand our directions to be, that the sereral ships under your orders shall each be on it way home, 
and to the eastward of Barrow Strait, whenever their stock of provision shall have been reduced to twelve months' full allowance; and commending you, and those employed under you, to the providence of God, we trust that success may crown your efforts, and that you may be the means of affording succour to those of our countrymen whose absence we have so long deplored.

Given under our hands this 16th day of April, 15ว2,

Northumberland.

HYDE PARKER.

Pitips Hornby.

Thos. Herbert.

To Str Edward Belcher, C.B., Alex. Milne.

Captain of Her Majesty's Ship Assistance, at Greenkithe.

By Command of their Lordships,

W. A. B. Hamiton.

No. II.

By the Commissioners for executing the Office of Lord High Admiral of the United Kingdom of Great Britain and Ireland, etc.

We have to inform you that we have despatched her Majesty's steamvessel 'Phonix,' under the command of Commander' Inglefield, with the 'Breadalbane' transport, to Bcchey Island, for" the purpose of replenishing the ships under your command with stores and prorisions, in case your supplies may have becn so far reduced by the depôt formed at Melville Island and the various cachettes on the coast as to prevent you from continuing further search for Sir Joln Franklin during this season and the winter of 1553-54, if the information you may hare gained determine you to continue such further search.

2. In communicating with you on the subject of your former orders and the service on which you are cmployed, we are aware how impossible it is for us to send out any definitc instructions with reference to your future proceedings, when we are ignorant of the position in which you may now be placed, or whether any traces of Sir Joln Franklin's Expedition may have bcen found during last Antumm or the Spring of this year, and what steps you may have considered it most expedient to adopt. But if no trace of the missing ships lave been found beyond the Wellington Channel, and if it should appear that by 
the extended seareh you may lave been enabled to make in that quarter, that the missing ships did not proceed in that direction, and if Captain Kellett should have reached Melville Island, as directed by his instructions, and his land cxpeclitious should also lave failed iu finding any such trace, it does not appear to us that therc is any other direction in whieh a prospect of their discovery can be expceted. Every accessible part of the shores of the Polar Seas west of Lancaster Sound will have been visited without finding a traee of the missing ships, exeept their former station at Beechey Island in 18 t5 and 1816. In such a contingency as this, and if sueh should likewise be your opinion after mature consideration with the senior oftieers mider your eonmand, there appears no other course left but to abandou all further seareh.

3. But in ease you should have found any traee of the Expedition, it will be your duty to follow up that trace. In doing this you must excreise extreme eaution, so as not to lose your means of commuuication with Bechey Island; nor are you to ineur any lopeless risk by proceeding berond reasonable linits, for the safety of your own crews must be your first care. We place every confidence in your zeal and intelligence, and feel assured that you will aet with sound judgment in whitever situation you may be placed; we therefore leave it to you either to abandon the Expedition altogether, if you are of opinion that uo further steps can be practicably taken, or to send such of the ships to England as you may not require; transmitting by them to our Seeretary uot only a full aeeount of all yom proeedings, but eharts of all your diseoverics, and keeping us informed of your views and intentions, so that, if it should be neccssary, every requisite aid may be giveu you in the Summer of 1854.

4. Before your final departure from the Polar Seas, should you think proper to adopt that course, there appears one very important subjeet which will require your" serious eonsideration; and that is the present position of the ships under the eommand of Captain Collinson and Commander M'Clure, which entered the ice to the north-east of Point Barrow (Behring Straits), the latter in August, 1850, and the former in July, 1851. These officcrs with their respeetive crews may have been compelled by circumstances to abandon their ships. If such should be the case, they may probably attempt to reach Melville Island; and having had this in riew when you left England, we direeted in your instruetions that a depôt of provisions and other stores should be formed at that island. From this position they will no doubt 
endeavour to make their way to Beechey Island or Port Lcopold. It will therefore be your dnty, before returning to England, to be fully satisfied that a proper depôt of coals, provisions, etc. had been formed at Melville Island by Captain Kellett, and that clear information had also been left there that similar supplies would be found at Beechey Island.

5. This depôt on Beechey Island is to consist of a full store of coal, provisions, clothes, and other stores, and you will take care to have it most carefully secured against the depredations of bears or other animals; you are also to leave one of your ships there, with or withont a crew, as you may deem most advisable, so that Captain Collinson or Commander $\mathrm{M}^{\circ}$ Clure's parties nnay find every possible assistance which thcy may require, and have the meaus at thcir command of returning to England; but should you find it to be practicable to place the ship, or a depôt of stores, in a more adranced position, between Melville and Beechey Islands, it might be expedient to do so. This is a point on which you can form a better judgment than we can. Our most anrious wish is to establish the best possible arrangement with the view of giving succour and support to the crews of those ships, should they be compelled to seek refuge in the direction we have pointed out.

6. Having expressed these general riews, which will require your careful consideration, we leave it to you to take such steps as you may consider most expedient for meeting the circumstances of the case.

7. On the arrival of the transport at Beechey Island, you are immediately to hasten her discharge, and despatch her to England with the lcast possible delay; and you are not to detain the 'Phœuix" longer than may be necessary, or to risk her being frozen in, but to send her also to England with intelligence of your procecdings, exchanging any of her men, and sending iuvalids, ete.

Giren under our hands this 11th day of May, 1853,

(Signed)

To Sir E. Belcher, C.B.,

Captain of Her Majesty's Ship Assistance, Arctic Seas.

By Command of their Lordships,
J. R. G. GramaM.

Hrde Parker.

II. F. F. BERKELEY.

R. S. DUNDAs.

Aleix. Mulne. 
No. III.

Instructions to Captain Sir Eduard Belcher, C.B., or the Senior Officer of IItr Majesty's Ships at Beechey Island.

Sir,

Admiralty, April 28, 1854 .

My Lords Commissioners of the Admiralty have direeted Her Majesty's ships Phøenix and Talbot, under the orders of Captain Inglefield, to proeeed with provisions and stores to Beeehey Island, for the purpose of replenishing the ships and depots nuder yom orlers; and I an commanded by thcir Lordships to aequaint you that on the retmen of the 'Phøenix' from Beeehey Island last year, they had the satisfaetion of hearing of the safe arrival of Hcr Majesty's ship Investigator, under the command of Captain M[Clme, at Banks Land, having completed the discorery of the North-Thest Passage, thongh unhappily, without discovering traces of Sir John Franklin, and that part of the erew had becn cnabled to reach Captain Kellett's station at Melville Island. By despatches which they reccived from Behring Straits they have information that in August, 1851, Captain Collinson, in Her Majesty's ship Enterprise passed the entranee of the Colville River; and their Lordships trust by the reports he may have obtained from the natives of Prince Albert's Land, as well as from the reeords deposited by Captain II'Clure on his passage along that shore, that he may also have been enabled to reaeh some harbour on Banks Land, fiom whence he has made known his position either to Captain $\mathbf{M}$ 'Chre or Captain Kellett.

Their Lordships have desired me to direct your special attention to the measmes they now requirc to be adopted for at once witldrawing, if possible, the whole of the foree now cmployed in the search of Sir I. Franklin from the I'olar Seas; for cffecting this oljject they retrain from issuing any positive instruetions low yon are to act, or what steps you are to take, as they are aware you must be entirely guided by the position of the ships, and those varying cireumstances which in that region nust infuence your operations; but their Lordships' view may be stated generally as follows:-

]. If the crews of the 'Enterprise' and 'Investigator' are at Banks Land, they must abandon their ships, and every endearour slould bc made to get them to Becchey Island, that they may return to England. If this has already been effected, and Captain Kellett with his ships has returned from Melville Island, you are immediately to proered to lingland with the whole of the ships and their "ows, abandoning all 
further search for the missing Expedition, mless any circumstances (on cousultation with the senior officers of Her Majesty's ships) should indnce you to believe that you remaining out another year would tend to clear np the fate of our missing countrymen. But if Captain Kellett has been unable to move from his position at Melville Island, it may bc necessary to give orders to him to abandon the 'Resolute' and 'Intrepid,' and secure lis retreat to Beechey Island; but as this cannot be accomplished this year, you need not detain any officers or men who may have already reached Beechey Island, bnt send them to England forthwith.

2. Should no tidings have been heard of Captain Collinson in her Majesty's ship Enterprise, it becomes absolutely necessary to provide for his safety. For this purpose the Melville Island depôt must be replenished with provisions and stores; and it will be necessary for a ship and steam-tender to remain there, also the "North Star" or 'Talbot,' with a tender, at Beechey Island, and at those stations everything which can add to the health and comfort of the crews should be deposited; and having done this, it does not appear to their Lordships to be necessary that any of the other ships should remain another year in the Polar Sea, unless, as beforc stated, you consider further search to be prudcut and ncessary.

These are the views of their Lordships: their great object being to recall, with the least possible delay, the whole of the ships or crews named iu the margin, * if it can be done; if not possible to do so, they leave it to your judgment and discretion to send home such of them as may not be required, and to adopt those measures which you consider most necessary to cnsure the safety of Captain Collinson and his crew, and their specdy return to England. This, their Lordships are aware, must depend on the information you may have receired from Melville Island, the positiou of the respective ships under your orders, the state of the depôts, etc.; all their Lordships can do is to confide in your judgment, and they anthorize you to take such steps and give such ordcrs, and to make such exchanges of officers and men, as you may deem necessary for carying their wishes into effect.

They trust however Captain Collinson is safe; and if so, it will be a source of much satisfaction to them, if during the approaching Autumn the whole of your ships and crews shall arive in England.

* Assistance, Pioncer, Ricsolute, Intrepid, Enterprise, Investigator, North Star, Phonix, and Talbot. 
On the return of any of the ships to England from Bechey Island, it is desirable that the coast to the southward of Ponds Bay, namely, from the River Clyde towards Cape Walsingham, should be examined; and you are therefore to endearour, in your instruction to the ships procceding to England, to meet this contingency.

In the event of your liealth lendering it necessary for you to return to England, and the necessity of a part of the squadron remaining out another minter, you are to make known to the officer whom you may appoint to succeed you in command, all your views and arrangements respecting further proceedings.

Although this country is now at war with Russia, you are clearly to understand that yon are not to commit any hostile act whatever, the ships under your command having been fitted out for the sole purpose of aiding those engaged in scientific discoveries; and it being the established practice of all cirilized nations te consider vessels so cmployed as exempt fiom the operations of war.

\section{I am, Sir,}

Your most humble servant,

R. OSBORNE.

I have used the expression "nearly apparent," but at the sixth paragraph of these first Instruetions it will at onee oceur to my readers that my mission was not quite single. Independent of the leading feature of this seareh for Sir John Franklin, two others of Her Majesty's ships, under the eommand of Captain Collinson, C.B., and Commander M'Clure,-the 'Enterprise' and 'Investigator,'-were yet to occupy my attention, and that too of a nature not eontemplated, but, to my pereeption, to inerease in interest, as well as importanee, with eaeh sueeeeding season of my absenee from this eonntry; and unless reealled by intelligence of their safety, still demanding my presenee in those regions until every seeurity for their comfort and final relief was provided for by depôts of provisions, as well by leaving behind some 
vessel of the squadron to await either their arrival or reeall from England.

Other objects, not enumcrated, but clearly understood by my previous employment, will find their customary notiec, simply observing that, so far as scicnce was concerned, this Expedition was not, when not otherwise cngaged, to neglect its interests.

Fortunately, at the moment that I received my appointment, on the 10th of February, 1852, my old eompanions, Captain H. Kellett, C.B., and Commander Richards, volunteercd to support me, the former taking command of the 'Resolutc,' and the latter (third in command) of my own ship, the 'Assistance.' Commander M'Clintock, Mr. Loney and Mr. M'Dongall, Masters, had also scrved under me, the two latter in the 'Samarang.' The other officers were appointed, as having volunteered, and having served in the formor Expedition, under my predecessor, Captain Austin.

It has been customary to annex the names of the offieers cngaged in sueh Expcditions, and I shall therefore follow the example, which is simply an cxtract from the official 'Navy List:'-

\section{Assistayce. Resolute. North Star.}

Captain . . Sir E. Belcher, C.B. H. Kellett, C.B.

Commander G. H. Richards. . F. I. M'Clintockt . W. J. J. Pullen.

Lientenant. Sherard Osborn* . G. F. Mecham

Walter W. May . B. C. T. Pin

J. P. Cheyne . R. V. Hamilton

Mraster . . J. F. Loney . . G. F. M'Dongall . T. C. Pullen.

T. Allard* . . . F. T. Krabbét . . T. Shellabeert Surgeon . Darid Lyall, M.D. . W.T.Domville, M.D. R. M Cormick.

* Additional for 'Pioneer' tender, † For 'Intrepid' tender. + Sircond Master. 
Assistance, Resolute. Norti Stak.
Mates
F. B. Herbert
, R. Roche
A. H. Alston.
T. B. Grove .
G. S. Nares
F. W. Pym (act.) , Mons. De Bray.
Asst. Sury. J. B. Ricards* . . R. C. Scott† . . F.I.Toms (lent)
F. I. Toms

Bnatsrain. Mr. Taylor

Carpenter. Mr. Kerr

Deans

Officers and Crews 91

Includes-Ice Quarter-masters, Marines, etc. : Total, 222 ; of which each Tender took 30 individuals.

'The 'North Star' was added to the Squadron, in consequence of the great difficulty, indeed impossibility, of the other vessels embarking stores from a transport at Disco, and the further probability of my not touching at all on the eastern side of Baffin's Bay. Beyond these questions she was imperatively necessary as a depôt to fall back upon, should either the northern or western dirision meet with accident. Commander Pullen, having just returned from his excursion along the northern coast of America, between Point Barrow and the Mackenzie, was selected for this command, with a reduced crew, so as to derive the utmost possible stowage. Having been ahready strengthened for former Arctic service, she was peculiarly adapted for this spccial depôt. But two clear months, and those at the most unfavourable season, intervenced for every preparation (the 15th April being originally determined on as the day of departure).

In as far as the vessels wcre concerned, they were supposed, laving been superintended by Captain Austin, to be complete. Indeed, thcre was no time to make alteration, if required.

In the Boat department Captain Austin had left me 
little to add, but that little was dne principally to the kind suggestions of Captain Hamilton, from whom I obtained a very beantiful model of a flat yawl, which, under the hands of the famed builder, Mr. Searle, and the inventor of a light shaving plank one-eighth of an inch in thiekness (Mr. Forster), produced four very beautiful ice-boats, two of sixteen and two of twenty feet, the heaviest weighing but $300 \mathrm{lbs}$. The heavy lifeboats, unmanageable in iee, were left behind, the other boats being more than suffieient to take eare of the crews.

In all such expeditions the numberless schemes proposed, and correspondenec to be answered, are enongh to oeeupy the attention most seriously, to the detriment of public duty, and the inconvenienee of being either drawn into interminable discussion, or the eharge of want of eourtesy to those unanswered. To all, who may feel so offended, I ean only plead, "not want of conrtesy," but inability by my own hand. They were answered generally by dictation.

The provisions, elothing, as well as the selection of the erews, remained as principal features, to which unremitting attention was neeessary.

Every possible faeility was afforded by their Lordships' "speeial ordcrs," as well as by all their leading officers in the several departments, so that, if anything went wrong, I alone must take upon myself the diseredit to a very great extent. Upon the first and vital point, the provisions, I was immediately in eommunication with Captain Milne, and the Comptroller of Victualling, Mr. Grant; and after reecnt exposures on preserved meats, it beeame a matter of very serious eonsideration. 
The beef and pork were eured at our naval establishments at Deptford, Haslar, and Plymouth. 'The prime pieces alone, free from bone, were selceted, and as reeent as the time permitted. At Haslar, under the especial superintendenee of Sir Edward Parry and Sir Joln Richardson, our store of pemmican was prepared.

Our other supplies were prineipally from the firms of Hogarth, Fortnmm and Mason, Gamble, Moir, Moore, Allsop, Edwards, Masson, Chollet and Co., Fadeuille; and to the result of my publie reports I must refer these parties for the general good opinion entertained of their supplies.

I do not inngine that the reading publie will feel any interest in the aceount of the general amount of provisions, comforts, ete. embarked; but as I liave myself frequently been disappointed at not finding the list of extras, and the valne assigned to them, I have inserted such a list in the Appendix, with the collective opinion thereon.

Among the leading sehemes proposed were the balloons used by my predecessor, and blasting by aid of galvanie ageney. In the latter I took peeuliar interest, owing eliefly to the suceess whielı attended that mode of simultaneous explosion on heary eharges at Round Down Cliff, near Dover, in 1943 (displacing 400,000 eubie yards by 18,500 lbs. of powder!). But ehamber-praetice and iee-praetice are yet to be tested, on whieh refer to separate article on Ice-Blasting: Appendix. On this mode alone we were not dependent, and were also fully provided witlı Biekford's mateh.

From the Ordnanee every possible attention was 
shown by Sir Thomas IIastings; and at the Royal Arsenal every portion of our equipment was complete within the ability of the Storekeeper. But to Colonel Colquhoun, my old friend and sometime companion, I feel under great obligation, for his unremitting, untining persevcrance and ingenuity in suggesting, as a practical iceman, many little articles of equipment whieh have proved eminently valuable. Our cylinders, of copper, containing twenty pounds of powder, and fitted with screw stuffing-boxes and galvanized india-rubber packing for the fuses, wcre most perfect. Our whalc rockets and tubes, liarpoon-guns, etc. all belong to his fertile mind.

To numerous other individuals not filling public situations our thanks are also due. But as this has bcen deemed a seientifie expedition in comnection with the grcat search, and in which I am happy to assoeiate the names of Kellett, Richards, Pullen, Loney, and M'Dongall, I am surc that they all feel with me, that I do well to reserve for our especial debt of gratitude that which is so eminently due to the Hydrographer, Rear-Admiral Sir Francis Bcaufort, for his watehful care over every publie as well as private convenience that might lessen our difficulties and tend to our comfort.

Associated with him, Colonel Sabine, Captain E. Johnson, and Mr. Glaisher, have eaeh rendered thcir time and servicc to the causc. That the great and prinary object of our Expedition could not allow of any delay or dcviation from our route, it is needless to observe. But the mind cannot tamely follow the sledgc-track, and constantly pore over the weary lesert of the floe: it requires occupation, relaxation, and amuscment. Such, scienee 
offers. And in the gloom of winter, independent of wellorganized registers of the eustomary requirements of our present improved profession, many seraps will be found worthy of note, and possibly of deeper interest than our seale of knowledge may possibly at the time deem important. The reeord of nonsense ean be obliterated, but the failure to reeord undeniable faets, only to be ritnessed onee in a life, is umpardonable.

The instruments from the Hydrographie Offiee rested on my seleetion from those in store. Several were made expressly for me, but the defieieney in reliable light altitude and azimuth eireles eould not be made up. Of these, at least of two more, I felt the want, even of good theodolites. Of the artificial blaek horizons I must say they were useless-untrue: but the entire blame, if any, rests with me. The five-inch azimnth and altitude, by Cary, was perfeet, and saved many a position. It was my eompanion for fifty-two days over very rongh ground, and to the summits of many momtains, without fault or damage.

In the compass department, the IIydrographer and Captain Johnson were unremitting in their endeavours to produee the best travelling instruments, and whieh should at the same time oceupy the smallest spaee. In all this they aeted with their eustomary forethought and ability; and if the magnetie needle ever was ealled in aid, the instruments were good.

But in the Aretic travelling season very seldom was it used. The sun, the great umpire in all matters of truth, was not often so long veiled, night or day, but we had his adviee. And here, indeed, the labour and forethought

roL. I. 
of the Hydrographer furnished the donbtful traveller, dubious of his variation, an uncring Mentor. This was a portable tabular compilation of azimuthal bearings of the sum, at intervals of twenty minutes, between the latitudes of $70^{\circ}$ and $51^{\circ}$ north, embraeing the travelling period between Nareh and September inelusive.

I should make but a feeble attempt to explain these matter's to the general rcader. Profcssional men need none. The words of our Hydrographer are too perfect, and they will speak for themselves.

"In the neighbourhood of the magnctic poles the compass becomes so sluggish as to be of little use, either to the mariner in his boat or to the traveller on lis sledge, and both are therefore obliged to depend, for the direetion of their eourse, on the bearing of the sun. But in high latitudes the path of the sun is inclined at so small an angle to the horizon, and its risc or fall is therefore so slow, that it is difficult to determine its azimutl or bearing by a rough altitude measurce from an horizon encumbered with iee; and a more eareful observation, by reflection, would not only eonsume much valuable time, but would bc impracticable in the earlier nontlss, from the severity of the weather, which would render it dangerous to expose the hands.

"Assuming, therefore, that at every station where the boat is moored, or the sledge party is encamped, the apparent time has been correctly ascertained, and the poeket watches duly set; then will the following tables, by showing the true bearing of the sum, enable the leader to adopt what course he pleases, and moreover to adhere to it, by repcatedly looking at his watch and estimating 
the angle between the sun and his track,-whieh operations requirc no unmeeessary exposure.

"The tables are computed for the zone comprised by the parallels of $70^{\circ}$ and $81^{\circ}$ north, and extend from the begimning of March to the end of September-the season most likely for exploring expeditions; but should their use be required before or after those periods, the intclligent traveller can readily estimate the allowanee he should make, by comparing the differences in the preceding and subsequent columns, and by obscrving the changes produced by the varying latitudes; though the reader will perceive, that even a material error in the assumed latitude would be scarcely appreciable in taking up a line of mareh." $-F . B$.

This merely cvinces the seientific interest in the matter. The compasses themselves werc cnclosed in neat leathern cases, suspended by a belt (spare pins and needles included), and the magnetic needle itself so adapted to the eard that at noon the compass could be set by the sum to tell the true meridien; and thms, mutil a fresh opportunity was afforded of obtaining further proof of the time by that cheering luminary, the traveller was relieved of the perplexities attending the correction for variations amounting to almost half the cirele in extent, $142^{\circ}$ to $156^{\circ}$.

The librarics furnished to each vessel contained all that was asked, which, aided by privatc collections, left nothing to be wished for in that department. A very excellent printing press, with full type, was supplied to the lcading commands, and was found useful.

In the comforts and extras for the sick, and for the complete equipment for the collection and preservation 
of rare objects, and all matters conneeted with natural history, our acknowledgments are specially due to Sir William Bumett, the Director-General of the Medical Department of the Navy.

The tents, sledges, and gencral equipments, as on the last expedition, were furnished by the Dockyard at Woolwich. Gutta-pereha eases of all deseriptions were provided, but none succeeded: they will not stand intense or moderate cold ; but some adaptation of this, or Jeffries' marine glue, wonld, I an satisfied, under judicious arrangement, prove highly important.

On the 19th of March the ship left the dry dock, making a most ominous lureh, and was secmred alongside the Dockyard. On the 25th, hauled off to the 'Charger" hulk, and nothing appeared likely to detain us beyond the contemplated day, April 15.

On the 10th of April all the vessels were in the stream, and constantly erowded by inquiring and interested visitors. On the Monday the magnetie instruments werc embarked, and a scries of very valuable thermoneters, specially prepared, from Greenwich and Kew Observatories. Thesday and Wednesday were exciting days: the presentation of twenty-five silken wrought bamers for the sledges, by ladies deeply interested in our suecess, and our leave-taking from those warmly esteemed friends and their relatives, will never be effaced from our memorics.

To the Lords of the Admiralty gencrally, to Captain Hamilton, Captain Milne, and Mr. Grant, I personally owe my acknowledgments, for the kindness and facilities afforded me throughont the eqnipment of this Expedition. 
To Mr. Barrow all are deeply indebted for lis undeviating kindness, antieipating wants which in our cxcited preparation we had but little leisurc to dicam of, and for promises fully realized during our absenee.

Under sueh eonditions, like spoiled children, witl crerything our own way-with cren the weather favouring every notion of our cquipment-behold the Expedition ready, if need be, at the appointed hour!

I have an almost superstitious dread of indecision, and do not eonsider men liable to it fit for any species of trust. And under such feelings, on the 15th of April, much to my relief, the Squadron slipped their fasts to the hulks to whieh they had been sccured, and, towed by the steam-tugs, proceceled down the river.

It was a deeply interesting scene in erery sense. Groups might be notieed on the Doekyard walls, seanning with eager interest for the last signal. Now a white handkerchief rose and fell with an almost passionate aetion. On board frequently a laced-eap individnal might be noticed intently gazing through a tcleseope, and suddenly holding up the badge of recognition. Often the ware of the blunt seaman's hand told where his heart was, "without leave." Fortunately the steam-tug dispensed with any but the saered duties of the last farewell.

In addition to these intcresting matters, the Doekyard authorities lad summoned the workmen to line the walls, the band striking up 'Should auld lang syne' and other' appropriate tunes, between the peals of ehecrs which kept our erews incessantly engaged, and which were responded to with equal vigour. This friendly fire was again taken up by our warm-hearted friends, the True 
Bhues of the Arsenal, and finally by a very unexpeeted sally from the Minié Rifle division at the Marshes, who had advaneed to the river-side.

And now all was silent. Deep thought prevailed, and the fidgety, short walk elearly indicated that some weight had been removed, and that duty was songht for ehange.

Shortly after noon the first stage of our eventful journey was aeeomplished, and the vessels seeured to their mooring-buoys at Greenhithe.

On the 16th the vessels were sivung for loeal attraetion due to the iron on the eompasses. My duties earried me to London. Captain Johnson performed this duty, Captain Kellett attending to his own ship. 'The stowage and iron fittings of the tenders remaining nearly the same, the tables for those vessels remained unehanged.

'The 'North Star,' having been detained by provision still unstowed, dropped down and joined company. The powder was embarked in rather large quantity for blasting purposes, and nothing now prevented our proceding but final instruetions, and the eustomary visit of the Lords of the Admiralty, whieh had ahready been duly notified.

On Monday, the 19th, the Board, eomprising His Grace the Duke of Northumberland, Rear-Admiral Sir P. Hornby, Captain Sir T. Herbert, Captain Milne, the Private Seeretary, and Sir B. W. Walker, the Surveyor of the Navy, inspeeted the ships, offieers, and erews. Privy Comneil duties requiring the attendanee of the Duke in town, the Board left rather in haste, leaving me to receive and entertain Prinee D'Aguila, from the Neapolitan Court, for whieh purpose the state barge had been sent down with Mr. Gore, flag-lientenant, from Woolwich. 
After His Royal Highness had inspected the vessels, he returned to London.

On the 20th Commodore Eden anived with the payclerks, paid the erew up to this date, at which they commence their double pay, and six montlis' ordinary pay in advance (two montls' being eustomary). Under ordinary circumstances, the payment, with such facility to escape, many having no men-of-war's time, would have been considered hazardous. We had no sueh feeling on the whole, nor were we deceived. A finer body of men never trod the decks of any of Her Majesty's ships of war. Our North Sea pilots being embarked-the same who took out Sir John Franklin having been allotted to us-I went to London to receive my final instructions, returning by eleven o'clock that night, accompanied by a warm-hearted friend, who had rolunteered to see me to the Orkneys, and be the bearer of our last adieus. Such friends are not butterflies. My detention to this date was by superior will.

Shortly after four A.M. on the morning of the 2lst we slipped our moorings. 'The Squadron, towed by the 'Lightning,' 'African,' and 'Monkey,' and tenders under steam, quitted Greenhithe before the good people lad time to open their eyes, or think of anything like cheering. About eight o'elock we sighted the ships at Sheerness, the 'Ocean' bearing the broad pendant of Commodore Hope, Admiral the IIonourable Josecline Percy being absent on leave.

About nine o'clock, casting off the steamers, we anchored at the Nore, in order to complete the stowage of the 'North Star,' and to make good certain defects 
causcd by the 'Pionecr' rumning into us. Here we wcre joined by the 'Basilisk' and 'Desperate,' reserve warsteamers, commanded by Commander Gardiner and Lientenant Stevens, ordered to accompany us as far as the 20th meridian west; the 'African' to tow for six days from the Nore.

Commodore Hope came off in the steam-tender 'Sprightly, and, in order to cxpedite our supplies, I accompanied him to the Dockyard, the 'Monkey' and 'African' also ruming in to coal.

Ilaving paid my respeets to the Admiral's lady and family, and invited them to visit the ship during our detention, her daughters, as well as those of my old friend Sir Charles and Lady Colville, availed themselves, with other visitors, of the opportumity.

At threc o'clock, our defects having been made good, we took leave of our friends, the Commodore passing under the stern of each vesscl, giving and receiving in return our thee last and most exeiting checrs; for here wc felt that the final knot was cut which connected us with civilized England.

Our anchors were tripped, and, towed by our respective tugs through the lowering mists which hung over the embouchure of the Thames, we took our last look at the shores of Kent, and dived to our cabins, to meditate on the great work we had undertakcn; - not in pride of command, but in the feeling that we were merely following up the cluc which others had barely left us enough to hold on by-hardly enough to warp ahead with. 


\section{CHAPTER I.}

At Sea.-Reach the Orkneys.-Strommess.-Scarcity of Stock.-Departure of the 'Basilisk' and 'Desperate.'-Enter Baffin's Bay.Whalefish Islands.-Reccption by Esquimaux.-Lievely.-Disasters. -Moored at Lierely.-Survey of the Port.-Q Quit Lievely.-Scarch for Coal.-Quit the IT aigat.

Up to this moment all has gone well. The sun has shed his eheering ray on all our movements, and not a day's rain interfered either with our ligging or embarkation of stores. One eannot but be grateful for all these benefits, and deem them but a prelude, under God's blessing, to a fortunate termination to our efforts.

In tow of the stem-tugs 'Monkey' and 'Afriean,' and aceompanied by the 'Desperate,' 'Basilisk,' 'Lightning,' and our steam-tender's 'Pioneer' and 'Intrepid,' we formed rather an imposing than warlike squadron. 'The tide being in our favour, we moved rapidly through the shoals of the 'Thames-mouth, and entering the North Sea soon began to feel the old sensations of being again on the oeean. The breeze freshening fast, and my instruetions direeting the return of the 'Lightning' and 'Monkey' from the Sunk Light off Harwieh, the 'Intrepid' also having signalled defeets in unaehinery, I deternined on 
anchoring for the night, complete 'Desperate' with eoal from 'Monkey, and despatch the latter vessel to Woolwieh.

Before daylight, the 'Intrepid' having made good defects, we again moved forward; the 'Assistamee' towed by the 'Basilisk;' the 'Resolute' by the 'Desperate;' 'North Star' by 'Afriean ;' and 'Lightning,' 'Intrepid,' and 'Pioneer' under steam; but the breeze soon rendering towing inconvenient, sail was made, and eacl vessel moved independently. As the sea rapidly inereased, and would soon render commmieation unsafe, I despatelied my last eommunieation by the 'Lightning,' direeting ler return to Woolwielı; and as the breeze very soon inereased and separated the Squadron, and 'Afriean' dicl not rejoin, I imagine that she followed the 'Lightning:'

April §3.-About one A.M. we rounded the Dudgeon Light and steered for Buchamess, where the eonsorts, 'North Star' exeepted, rejoined.

April 25.-About three A.M. on the morning of the 25 th, the breeze failing, the steamer resumed tow, and about seven A.M. the 'North Star' was seen under the high land of Caitlmess. About seven we took on board an Orkney pilot, and shortly before noon, under a most brilliant and eheering sun, not a breeze moving and sea glassy smooth, we tlireaded the Orkneys, passing Long Hope, where I had at first purposed anchoring, and by noon were safely anchored off the town of Strommess. 'The 'Basilisk' was then sent to aid the 'North Stror.' The remainder of the Squadron gradually dropped in, and before sunset all were in scenrity, the tenders and steaners within the inner harbour. 
This being Sunday, and the inlabitants at ehureh at the time of onr arrival, we were not visited until the afternoon, when the Custom-house anthorities and Dr. Hanilton eame on board, tendering their serviees.

Understanding from these gentlemen that a vossel laden with eoal on sale was within the harbour, I was cnabled, before the arrival of the steamers, to make arrangements for their entering at onee, to transfer it more eonveniently without further delay or expenditure of fuel. This, probably, was the first time that the inner harbour of Strommess bore on its watel's four steamers of war of such length and tomnage.

Unfortunately the Post-office at Kirkwall did not forward our letters, notwithstanding that the offieial envelopes were addressed to Strommess, - possibly, in the expeetation that the seekers for them would find their way thither. In this they were not mistaken, as onr younger men were rather anxious to eommenee their explorations and breathe a little pure air,_-an example which Captain Kellett and nuyself soon followed ̀̀ pied, on the rising ground in the immediate vieinity. The observations on the tom and seenery are hardly expeeted in these days, and amount to $\mathrm{mi}$. Onr attention was chiefly dineeted to the points and faeilities for watering, obtaining the neeessary supplies, and other trivial duties.

Nor was time idly expended on board. We had as yet had but our first shaking, and it was not long before my indefatigable aid, Commander Richards, fond stowholes for many objeets whieh doubtless puzzled him, and whiel probably never before lumbered the quarter-deek of any vessel bearing a pendant. These comprised heavy 
cases of concentrated sulphuric acid (oil of vitriol), galvanic batteries, balloon gear, cum multis aliis, which would probably involve more querics than I would care to answer. At every step thcse were really obstructions, and some were subjects not to be ill-treated with impunity, even thus far out of Scotland. In the midst of all these duties, involving almost a restowage of the ship, watering, coaling, etc., we bcgan to discover that our private stock of animals and other requisites, involving the comfort of both inner and outer man, had been most pcculiarly overlooked. The natives, too, had discovercd our wcakness, from a ccrtain furor displaycd by one or two leading purchasers, and did not even, while thus patriotically and philanthropically engaged, fail in forming just cstinates of the contents of our purses, probably understanding from previous visitors that men-of-war's men are fair gamie.

Independent of any such fecling, and setting aside any presumption that stock herc is cheap and easy to be procurcd, I would strongly advise my brother officcrs not to trust to any such fallacy beyond eggs, milk, and butter. Animals, ducks, fowls, etc., are not fit to kill, do not live, and turn out eventually very dear bargains. But this applics in most minor ports. It is only the practised stockman who will supply objects fit to eat, or which will endure the caging on board slips.

Our rambles cxhibitcd to us, or rather to mysclf, no improvement since my risit to the Orkneys in 1821,--a private individual, and most warmly and hospitably entertained by some good friends at Kirkwall, whose names have escaped my menlory, but thcir kindncss has not 
been forgotten. Possibly they reeolleet me at the Manse only as the inquisitive "stone-breaker." I rode over to Strommess and baek the same evening. To expect hospitality or attention under present ciremmstanees would be unfair: who eould entertain sueli an arny of loeusts?

One of our deserters, or rather an unfortunate middy whose dreams were more powerful than the eheers at parting, had now giren himself up, having posted and railed, express, through two parts at least of Great Britain to overtake us, and erossed by gig from Kirkwall. As there was no "eleque without leave," 110 further" questions were asked; I was only too glad to see him. By him we reeeived information that the steamer whieh brought him to Kirkwall would depart on the next day evening for Aberdeen.

I had now to lose my kind eompanion Mr. E. Ray. We took leave of him on the evening of the $27 \mathrm{th}$, seeing him off by the mail-eart; and to his kindness, and interferenee with the Post-offiee, I fecl that we in a great measure owe the reeption of our letter's by our returu officers. He earried with him our final despatehes, with whieh he would sail at dawn on the morning following for Aberdeen.

April 2S.-Fortunately we obtained the sun for our ehronometers at two P.M., just as the weather began to exhibit a suspieious, murky appearanee, when the Squadron weighed, eleared the islands, and was onee more on its forward progress. The absenee of the 'Afriean' we now felt seriously; her serviees might have proved important to tow out the 'North Star,' as in this thick weather one more tug would have kept us securely eon- 
nected. We were eompelled to lie to-and that is, under tow, a most tedious operation-until one of the stcamers could extricate the 'North Star ;' mueh valuable calm and offing in this variable climate was thus lost.

Having fairly gained an offing, the 'Basilisk' was allotted to the 'Assistancc' and tenders, and the 'Desperate' to the 'Resolutc' and 'North Star.' About four A.M. on the 29th, we passed Cape Wrath lights, and before nightfall had cleared the northern end of Lewis Island.

We were now truly at sea. My instruetions were explicitly limited to taking the two steam aids as far as the longitude of $20^{\circ}$ west. It was my intention, on reaching that meridian, to eomplete the tenders with coal, and then release them. That the orders were worded so imperatively was unfortunate. IIad it been simply, not to carry them beyond thcir safe means of return, I might easily have taken the supplies out at an earlier date, or, at reduced coal, worked a day or morc longer, until smoother water prevailed

Unfortunately this distanee was not made good nntil Sunday, the 2nd of May, when the labour did not appear suffieiently imperative to disturb that day of rest; but, the breeze suddenly freshening at nightfall, and towing-hawsers parting, it beeame neeessary to make sail independently.

Bad weather continued until the Sth of May, when, taking advantage of a hull, we commmicated with the steamers, exchanging a marine and taking their towinghawsers. Our despatches werc sent by the 'Desperate,' Lieutenant Stevcns, as being more likcly, by steam and 
canvas combined, to reach Plymoutl, and, by rail, London, earlier than the 'Basilisk,' bound to Portsmouth with paddles and eanvas. Mueh pleased with the diligence and handling of these vessels by their respective commanders, we eheered and parted company, thus severing the last link on this side of Greenland.

Shortly after parting with the stenmers, we fell in with a dead whale, and began to experienee the eustomary visitation of the fish-hunting birds, mollymoks, gulls, ete., of Greenland. On the 15th of May, being in latitude $57^{\circ} 56^{\prime}$ north and longitude $35^{\circ} 26^{\prime}$ west, we were visited by a snow-bunting, and on the 20th noticed the first iceberg; but, although we passed between several small piees of iee, neither the air nor sea exlibited any ehange of temperature.

On the 1st of May we passed Cape Farewell, and on the ath were beealmed off Godhavm. The dredge was sent down and some few shells obtained, but the eorfish and halibut, notwithstanding the most enticing baits were tried, eould not be induced to bite. Suddenly a long rolling swell eane in from the south-west, causing the ressels to piteh very heavily, and, as they rose to the summit of the wave, exhibiting the land-iee, not before notieed, as lining the coast-line. The effect was curious, and not pleasing.

The enstomary routine of such tedious navigation contimued until the 29th, when we got a fair wind and ran up to the Whalefish Islands.

As eustomary in these eases, referenee was made to "the voyages," and to persons on board who had been here before; but no one eould afford any information 
calculated to be of use. We were therefore compelled to grope our way, aided by our dead reckoning.

To the seaman secking Whalefish Islands nothing cm be more deeeitful than the first sight of the group, when distant about ten miles, and more particularly if the wind should be light and the sea very smooth, when probably it would prove glassy calm at the islands. They would then appear merely like a scattered reef on the surface of the ocean; but the mystery is easily dispelled. If they display a wide extent, you are to the south-west; and if you bring them to bear nearly time north, you munst be in the fair way for the entranee, which is by the south-east end of the sonthern island. E.N.E. by compass, they show in the centre of Disco and as one island.

The two main islands are high, about six lundred feet, and will exhibit a deep gap between them. It is in this gap, about half a cable wide, that vessels anchor. The Danish Establishment is on the southern island, termed Kron-Prins Island. If the breeze be steady, shave it on the east, as a roek lies off about a eable's length north-north-east true, and run for the gap until Boat Isle is seen midway in the channel; drop anchor in the mouth, and veer to secure to either or both shores. Five of Her Majesty's ships were safely berthed well within the mouth.

The latitude of Boat Island was determined to belatitude $65^{\circ} 5 \mathrm{~S}^{\prime} 42^{\prime \prime} \mathrm{N}$., longitude $53^{\circ} 13^{\prime} \mathrm{W}$., variation $70^{\circ} 46^{\prime} 39^{\prime \prime} \mathrm{W}$.

In Captain Mangles' account I notice that Sir Johm franklin was much in the same dilemina as ourselves; 
indeed when I was first informed that they were truly the Whalefish Islands, I eould scareely eredit it. They did not appear to afford the slightest chanee of shelter.

On the other land, no seaman who has onee visited thenl, and used his cyes, can for one instant be in doubt. There are 10 others to mislead him, if he approaches them on the proper bearing. Diseo may also be in sight, and the very remarkable mountain over Lievely will, bearing north (true), be an infallible aid. If these islands should be sought from the northward, bring the eastermmost point of the high eastern island to bear south true, and rum down until you perceive the channel, with a roek in the eentre, between the two highest islands. Round all rocks easterly, at a good berth, and enter this ehannel boldly; steer for the starboard ehamel; pass Boat Island; after whieh rum for the port side, to avoid a roek, elose in shore, on the starboard liand; anchor as you open the narrows. Bergs sometimes plant themselves at the sonthern month of this gully; it is therefore safer to be well within, as they ground and may break your anehor, if you should be just outside the openiug.

'The moment any vessel is notieed steering for these islands, the Esquimaux, or" "Huskies," as the Danes eustomarily term them, come off in suffieient numbers to satisfy you that you are near the hamnts of uneivilized men, and will afford sufficient information to guide any stranger to his anchorage. They are all in the pay of, or dependent on, the Danish Resident there or at Lievely, and earry on the seal-fishery for the Company's interest.

* "Husky" is their own term. I recollect the chorus to a song at Kamtchatka was "Husky, Husky."

VOL. I. 
The establishment at the Whalefish Islands must have degenerated in a most extraordinary degree of late ycars, if it ever deserved the reputation of having one decent louse in it within the nemory of man. Never did I witness such utter filth and degradation in any Esquimaux western tribe in my life; but visits to Lievely, Upernavik, and Cape York, satisfy me that the tribes here are more filthy. Upon the oecasion of our visit, nine kaiacks formed in line ahead, awaiting our arrival, with lanees poiscd, as if we had been some nighty monster of the deep they intended to attack. These kaiacks probably were manned by their select nen, and intended to exhibit a visit of courtesy, as they were better clad than we afterwards noticed. They kept up with the ship, throwing their spears at objects which offered, recovering then with grcat agility as they came up with them, buoyed by their light fish-bladder. One unfortunate lumme was struck, probably gazing in astonishment at us, but pursuit was orerbalanced by the clance of the nice things they might pick up from us, particularly as it was our dimner homr, and Jack is gencrous in his way. They probably had seen the ship before, bnt no whaler ever could be mistaken for her. Mamy of them have some pretension to liead and stern, and are even gilded; but why our predecessor's deened it expedicnt to make our vessels so unlike anything before created, not a little perplexes me, for in truth we have less of the heavy ice to encountcr. The day will yet arrive when whalers, or those intending to amuse themselves in "norther'n researches," will prefer clippermoulded vessels, instead of tea-chests. 
Our time liere, whilst refitting, watering, and restowing our loolds, was cmployed examining the islands and shooting ducks, eliefly the eider (Anas mollissima). As to any communication with the so-called Governor, or oil-cooper to the settlement, only distinguishable by a white face and reddish hair from the as filthy Esquimaux, there was no inducement. Taking our departure by the northern route, on the 5th of Jnne, we passed up the eastern side of the group, in seareli of Lievely.

The same remarks apply to information about Lievely. It must be sought by latitude and longitude, being situated in latitude $69^{\circ} 13^{\prime} 56^{\prime \prime} \mathrm{N}$, longitude $53^{\circ} 42^{\prime} \mathrm{W}$.

The surest and unerring mark is a flat-crowned beetling cliff, about one-third from the western point of Disco, where indeed they appear to terminate. On nearing the land, which is "safe to," the rocks which form the port of Lievely will be seen to project well to the southward, and fine gravelly beaches eommence inlmediately to the eastward of the rocks which, extcrnally, form this very close port. It is indeed the port of the island of Lievely. At about two miles westerly from these fine dark gravelly beaches, the jutting angular headland will exhibit the great red beacon, which at once scts further doubt at' rest.

This beacon is on the outer soutl-west head, and has a deep bay within, which at first sight might be nnistaken for the port. Steer past this bay on the outer side of the islet, which lies off, and round the next inner point, within which a deep strait will open, and pilots will meet the vessel. The port lies at the eastern extremity of this strait, and is a most perfeet, land-locked, safe anchorage. 
The town eannot be scen until you reach the eastern bight of this strait.

In our ease, the tenders having been direeted to look ont, the beacon was signalled by 'Pioneer ;' and ruming in with the ship to a safe distanee, I left in my gig, to aseertain where the port lay. I was mueh puzzled by the outer bay; but immediately on rounding the inner point, the warping-rings let into the roeks, and numbered, elcarly indieated where to proeecl. I was not a little surprised to find that no pilots were eoming out, and, until I renehed the Resident's house, that none were ordered; but they immediately aeeompanied me in their own whale-boat, and on opening the point I made the signal to the ship 'to steer for my position,' advaneing in the course which she was to maintain. This was immediately complied with by Commander Richards, and rejoining off False Bay, we stood in, prepared to beat up, to the harbour. I had hoped that the ship would have beat in to the anchorage in deeent style; but fate scemed to deeree unusual disasters, and either flurries of wind or counter-emrrents aeted to the annoyanee of each. The 'Assistance,' always weatherly outside, would not keep to the wind, and lost ground in tacking. The pilots (too many) were all uttering unintelligible jargon, and giving eontrary orders, twiee putting us on the same roek without dannge, owing to its abruptness; so that I found, with sueh a strong breeze prevailing, that it was neeessary to anchol'. In the meantime the 'Pioneer' had made love to an ieeberg, whieh deprived her of her mizenmast. 'Intrepid' grounded in stays; 'Resolute' anchored; and next morning, after it moderated, and the 
wind favoured us to get in, 'North Star' tailed on the harbour spit, and remained one tide. We all had our taste of beating into Lievcly. Had all this happened to raw hands, it would have been clear cnough, but we had too many surcyors accustomed to greater diffieultics. The undertow must have been the cause, by the strong wind from the eastward forcing the water through the channel on the east, at the same moment as the flood was making high water on the surfaee from the wcst. One decided point in my own mind was the want of rake to our mizennast. 'This I liad strongly mrged before learing Woolwich, but it was not complied with. I now insisted on its being done: the result las proved that I was right.

Having all the Squadron now securely moored in this beautiful little liarbour-none under the length of any five hundred ton ship-I began to reflect how any onc could venture to waste time by frequenting the Whalefish Islands, when such a complete refuge as Lievely could be gained, with a civilized Governor, clad at least with respectable clothing, and gentlemanly in manners, and where every other accommodation whiel a port should afford was to be obtaincd. Port charges might prevent the gencrality of whaling ships from entry, but this could not influence vessels of war. Referring to Sir E. Parry's remarks, I notice that he only visited this port in his boat in 15:4, and, unless he sounded it, or consulted the pilots, could hardly be supposed to know its eapacity. He considers it excellent for suall ressels, bnt narrow for ships of three hundred or four liundred tons. I should be very glad of such a harbour for three sail 
of the line. It conveniently accommodates five sail, in berths where fifty-gun frigates would be safer than in Portsmouth harbour.

The Governor, Mr. Erasmus Möeldrıp, showed us every attention, and afforded us all the information in his power. A survey was made of the port and entranee, and some of our sportsmen managed to find exereise and amusement, if not game, by climbing some of the frowning hills immediately over the anchorage, particularly that whieh I have notieed as the best guide in seeking this port. This hill, estimated by some of those who had not tried its aseent, was estimated at seven to eight hundred feet above the level; measurement, however, proved it to be 2100 feet. The Governor and family were entertained on board both vessels, and some of the younger hands had an opportunity of getting up their polkas and quadrilles, ete., with some of the half-breeds of Danes, who really performed to admiration, and having been duly dressed, from "the theatre property," in European feminine eostume, were not wanting in beauty.

Having obtained seal-skins for booting our travelling parties, and other supplies, we quitted Lievely on the 10 th of Jume, intending to examine a loeality in the Waigat, where the Governor informed me that eoal abounded, and might be obtained at the beaeh with little labour, but that it was eheaper for them to get it from England, than to pay the wages demanded by the Esquimaux.* Another spot, within forty miles, was also named.

As the iee threatened westerly, I loped to get round inside it by the Waigat ehanmel, eoming out by the north

\footnotetext{
* This roal siner visited by the 'Phenix.'
} 
end of Diseo, and therefore determined to seek this coal. Our dogs were proeured here; but we did wrong in trusting solely to the Governor: he had some whieh le wished to get rid of. We were informed that all the best bred were absent limnting.

Light airs delaying us, I quitted the ship in my gig, near the entranee of the Waigat-a sound which divides Diseo Island from Greculand; and keeping along the shore, at length reaehed a spot where the banks exhibited ummistakable signs of a coal-bearing distriet. The eoal was found in detaehed piees on the beaeh, but not in suffieient quantity to reward delay. I therefore moved easterly, to the mouth of a great valley barred by sand, and whieh appeared during the summer season to be the bed of some great river. Within, it being low water, it was eut up by streams in all direetions, the sea-bench forming a kind of barrier. Strewed along this sandy beaeh, about three bags of loose pieees were pieked up; but no eliffs, banks, or roeks near, whieh exhibited the slightest ehanee of eoal in situ. The surrounding hills appeared, at two or three miles inland, to be formed of some very dark stone, constantly disintegrating and tumbling down into the valleys; but neither time nor labour eould be afforded to examine them. The Governol's explanation, that " it would not repay the labour of eolleetion," was but too apparent. That this was one of the spots alluded to, as "near a house forty miles east," I was fully satisfied, as he had informed me that it was at a sandy beach not far beyond where they had a house; and this house I visited, and similar coal to that pieked up on the beach easterly had there been 
nsed as fucl. Further along the eoast a party again landed, but no traces of conl: it must therefore lie inland, and is probably brought down by the heavy strcams which the thaws throw down through the valleys. The interval betwecn the nenrest mountain-faces and the shore was covered by a thiek peaty soil, in which a person would sink deeply in any thaw; the labour, therefore, of transporting coal, even if it existed within one mile, would be excessive.

During the day and night previous to our departure from Lievely, it had snowed heavily, and corercd the land generally to some depth; but the line separating this coal-bearing region was most elearly delincated by the total absencc of snow, - doubtless due to the greneration of heat by the previous thaws and sun's rays acting npon the shaly beds, charged with iron pyrites. To the eye, as viewed by telcscope, the hill-ridges appeared to be composed of a slaty shale, or coal, eropping out oceasionally like dykes, and were in immediatc association with a ferruginous clay, deeply ehamnelled by late thaws.

The coal found was not bituninous, but morc of a slaty wood-coal; burned well and retained its heat when mixed with other coal, and would be admirably adapted as an aid for our steamers, especially for banking up or retaining low stean.

A whitc fox came to inquire our reasons for visiting this part of the country, but departed abruptly before he eame within gunshot.

As the evening continucd calm, I sent the officers on shore, to shoot and amuse thcmselves by making further rescarches inland towards the black formations; this 
latter they found too tedious, by reason of the yielding peat over whieh they had to travel; but they were more fortunate in seeuring several braee of ptarmigan, now very aceptable to our invalids, - particularly Captain Kellett, nearly on his legs again, and regaining his customary spirits.

June 1:- - Having eontended in this neighboumood for some time with strong breezes, and loose iee inereasing so fast as to render the navigation a severe duty to the erew, even to keep the ship elear of it, and the prospeet to windward unsatisfactory, I bore up round the south end of the island, and, passing Lievely, reaehed the sea again, now invested with larger and more numerous bergs than we had before notieed. This, however, indieating a great southerly motion, afforded me hopes of making an easier passage, as these monsters generally elear away all before them and break ip the small floes.

I notice that the Danes differ from us, in terming these masses "blinks," whereas we apply that term to the reflection of iee or water, as ice-blink, water-sky. 


\section{CHAP'IER II.}

Anchor at Upernavik.--The Squadron adrift.-Dangers numerous.Prospects of the Voyage.-Browne Islands.-Preparation for Flitting.-The 'Resolnte' nipped.-Docking.-Blasting Ice.-Wreck of the 'Regalia.'-Mcet a 17 haler.-Irregularities of the Crew.-Melville Bay.-Floe Law.-Capture a Bear.-Cape York.

Ox the I6th of June we had reached the westem entranee of the Waigat Cliannel, and found it elosely bloeked; the iee also, to seaward and the north, apparently closely paeked; but in this we were undeeeived as we neared it, several lanes opening, which admitted of sailing, by a little enution in seleeting the weakest points for breach.ing. The floe picees, or flat iee, were so mueh enten into and rotten, that, if due ealeulation was made for the impetus in luming into them at almost natural fissures, no diffieulty existed in dividing them and reaching the next "lead." After some little exeitement of this nature, and giving a few shakes to the old eraft, merely to let her know that she must awaken to her old duties, we reaehed the open water, and were making good progress, unfettered by further obstacles, to the northward.

On the 1Sth we were off Anderson's Ilope; winds light and adverse. Reat up amongst the islands, and, 
as usual, no one able to speak distinetly to any land in sight,- - and yet so remarkable, that he who has onee seen ought never to forget it. Late in the evening, as we reached close in upon one of the islands, it was thought, on the view we had of a very high perpenchieular eliff (3300 feet), that it might be "Anderson's Hope;" but $I$, who had never before seen the land, knew full well where I was: but where to find the anchorage at Upernavik was the mystery to be solved. The difference between noon and midnight, in this latitude, was scarecly taken into account by us, and thercfore I felt surprise that no colour's were exhibited, or pilots came off. 'T'hey were all asleep; it was past nidnight.

Early on the 19th, a boat, manned by Esquimaux, eame off, but no Danes. At two A.M. I sent the cutter, with the master, to seek for anchorage and point out the settlement. Still no notice was taken of us by the Danes; nor could we distinguish the settlement. At length we noticed the entter, in a decp bight, with the signal flying for anchorage, and shortly after discovered the ehapel and residenee of the Superintendent (or Governor) on a point above.

Upon the return of the boat, we stood in to a small but suug bay, open to the northward, and anchored, securing to a small islet, as well as to an ieeberg grounded ofl the mouth of the bay.

I now proceeded to call upon the Governor, Karl Gelmeyden Flaiselier, and received from him every attention, apologizing for not sending out any pilots, as most vessels frequenting this place are well acquainted with the usual anchorage. We obtained about twenty 
good "water-skins" (a peenliar seal), for the soles of our travelling-boots, whieh we were unable to get at Lievely; purehased boots and moeassins, pup-seal skins for linings, and sundry euriosities, Esquimaux models. The priest also, Jens Miehael Peter Kragh, eame to pay lis respeets,- - a sharp, intelligent man, partieularly eonversant with the value of a British sovereign. Both these individuals were the offspring of mixed parents on the mother's side and Danish fathers, were born in Greenland, and partially edueated in Denmark. Their wives are Danish, and the ehildren interesting, animated, and likely to be handsome. We were also introdueed to a pretty darkeyed brunette, the daughter of Petersen, who aeeompanied Mr. Pemny as interpreter in his late expedition. In the window of the Resident we notieed several varieties of flowers in bloom, but prineipally natives of Greenland, although eommon in England.

We were most anxious to obtain seal's fleslı for the dogs of the expedition generally; but my endeavours were eompletely frustrated by the interferenee of private interests, by whieh the natives were induced to demand as mueh for one earease as the Governor informed me would have purchased all in the eolony. The result was, that all were disappointed; the Resident absolutely refusing to allow any sales under these exorbitant demands.

In the evening it eame on to blow very fresh, and I .now began to eongratulate myself in not trusting to the stability of bergs; our bower anehor was well placed, and an intervening roeky ledge prevented the berg from driving upon us.

'The 'Resolute' eommeneed by breaking adrift, owing 
to the turning of the berg; 'Pioneer' fell foul of her, taking away the jib-boom of 'Resolute,' and losing her' own fore-topmast. Both went adrift in a strong gale, with thiek fog, into the Strait.

Onr own berg, although elose in shore, took leare of us, earrying off the iee-anehors and hawsers of the 'Assistanee,' 'North Star,' and 'Intrepid.' 'The uneertain eondition of the 'Resolnte' and 'Pioneer,' in fog and bad weather, amongst roeks, kept us in mpleasant suspense during the night, but fortunately they rejoined the day following, when our hawsers, etc., were also reeovered. We dropped our seeond anehor, and rode it ont eomfortably, although the gusts at times were very heavy.

June 20.-The day turned out very fine,-bright sun, and little wind. After prayers, I took leave of the Resident, and joined the ressels outside, but, fog eonning on, had some diffieulty in eolleeting the Squadron.

We now passed in to the eastward, between the islands, into the Great Sound, having been informed that "Sir James Ross did so, and avoided mueh unpleasant iee." But in this we were mistaken. After knoeking about until midnight, frequently obseured from eaeh other, and the sight of land, by fog or snow-drift, and without any appearanee of an opening, I determined on effeeting my eseape by the first western outlet between the islands. Within, as far as we had proeeeded, the iee was fast. With our aeenstomed good fortune, we soon hit on a fair lead between them, and just eleared the southern band of iee, interposed between us and Upernarik.

This neighbonrhood is very dangerous to navigate, and I have been sinee informed, that seareely a whaler passes 
by this route without striking on, or diseovering, some new roek. Several were notieed by the 'Resolute,' as well as ourselves, just eapped by iee, and both eseaped once or twice; the 'Resolute' found out her mistake when intending to graze the iee whiel eoneealed the danger; great eantion must therefore be exereised. As to fixing the position of any whieh we saw on the eharts, it was impossible: fog and other diffieulties entirely prevented our knowing where we were.

If one ealmly easts his eye on the ehart, and there views the dots deeorating the eoast, eael of whieh is intended to represent an island-and sixty of such dots would represent sixty miles-the diffieulty of plaeing anything there to warn navigators may be understood.

The navigator in these regions must, like the pilots of the Bermudas, earry his ehart in his head, and use his eyes properly. Latitude and look-out may leelp him, but the water is rery deep-too deep for the lead-and but few somndings on the elart.

Before quitting this neighbourhood, I will endeavour to give my own opinion as to the approaeh to and anehorage at Upernavik. It is neeessary, in the first instance, to know the latitude and longitude of the plaee bound to. The anehorage point of Upernavik Bay is situated in latitude $72^{\circ} 4 \mathrm{~S}^{\prime} \mathrm{N}$. and longitude $55^{\circ} 53^{\prime} \mathrm{W}$., about one mile east of the elurch. The Danish vessel, which makes her annual visit, I am informed, moors within a line of roeks, in the depth of this bay, whielı forms a natural doek; and she is, I doubt not, in perfeet seeurity, if properly provided with ground-taekle. Our anelorage in the outer bay showed the flag-staff of the 
settlement open between the two onter islands, in eleven fathoms stiff elay, with a ledge of roeks, probably, between us and the anchor, as the grinding noise of our cables evineed, and the anehors and lawsers used in warping were entangled with mneh kelp. The anehor was let go when the flag-staff' was clear outside the roeky islet.

The approaeh to Upernavik is eonsidered to be safest by "the inner passage," immediately under the high eliffy part of Anderson's ITope, inside of the two islands. When the last point on the right exhibits the eastern passage open, haul easterly and southerly withal. The settlement will be noticed about south-east, on the starboard hand, with the Danish eolours flying, and a white-faeed ehapel beside it, unless you happen to do as we did-visit it at midnight: then, uven a gun, unless eliarged with sovereigns, might not elieit mueh attention. Even the Danes have very sound ideas of luxury: in such elimates it requires great indueement to get out of bed. Some of the officers of the 'Resolute,' I believe, visited the "Rookery" and Plumbago distriets; but of this I am unable to give any aceount.

Haring now, I conceive, done nuy duty to those maliners who may follow me (?), I shall proeeed with onr monotonous voyage; for really, but to seamen, I eannot flatter myself that bergs, floes, sailing ice, ete. will greatly interest any one not in want of sueh information. All narratives of voyages of this natnre demand great indulgenee from the general reader. One should possess the pen of Marryat, Hall, or Glascoek, and indeed eoin interesting matter, to induee any one to enter these pages. 
I camnot play the humorous or the buffoon, but truth, simple truth alone, in such pleasant tcrus as I can reduce it to, will prevail. I have notling to gain, nothing to fear: my own family motto must guide me throughout. Those who despise "Loyal au mort" and loyal to facts, must not depend too much for amusement in this narrative.

Our departure from Upernavik, to use the seaman's well-known expression, was the "hoisting in of our long boat." Henceforth we must be considered at sea, and dependent on our own resources. Cut off, for a serics of years, from any but our own companionship, and dependent in no small degree upon the bona fide constituents of our society, power ceases, and the will of the least amongst us may create bella, horrida bella. T'pon what a volcano do we stand! The sullen chicf, if he be so, must chew the cud, and vegetate ycar after year in sullemness and vexatiousness of spirit. No such purgatory could exist, better calculated for a man of narrow mind, -none so dangerous to a sensible mind. Such then being our fcclings, I proceed, in charity with all men, not perfect myself, and willing to overlook all faults in others, provided they do not, when I tell them of it, still continue to tread upon my corns.

I liad a very strong inclination to cut across direct for the west land, under the impression that we should find less obstruction; but the predoninant feeling bcing in favour of Mclville Bay, being myself but a Johnny Newcome, I submitted to the ice-masters and others, who thought they knew better, and followed up the whalers, reported to be about twenty days in advance of us. I 
an far from believing that I did right, with regard to the shortness of passage ; for I firmly believe, a very little perseveranee in maintaining our westing would have rewarded us by open water to the westward.

June 21.-The longest day, - and eertainly a rery long one, to most of the exeeutives at least. Thiek fog eame on, eausing a separation from our eonsorts, but fortunately eleared up in time to prevent misehief,-for no two appeared to have their heads in the same direetion. The 'Resolute' alone was standing direetly for us, having heard our guns and fog-signals, and answered them. The afternoon turned out beautiful. Aided by a light fair wind, we eontinued to thread the passages between the ieebergs, at one of whieh we tried the three-pouncler, shotted, expeeting the eoneussion of the air would eause some luge fragment to separate, partieularly as it exhibited many deep vertical fissures; but not the slightest splinter moved.

We soon reached the termination of the open water, and seeured the vessels to the floe or sheet of field-iee, areraging generally from three to four feet in thiekness, six-sevenths of whieh are supposed to be immersed; but we found by experiments, at a later date, that eight-ninths is nearer the truth. The weather being foggry, we were unable to see any distanee, or to seleet any position near to any probable opening.

On the morning of the $23 r^{\circ}$, on the fog elearing off, we diseovered that we were rather too elose to one of the Browne Islands, in four and a half fathoms, added to which the roeks under our bottom were too visible to be pleasant; moreover the ice was drifting us fast VOI. 1. 
towards the island. 'The 'Pioncer' was immediately put into requisition, and, liaving got her steam up, towed the whole Squadron into deeper water.

Ilad it not been for this unfortunate interference, I should have landed, and obtained observations, to fix some of the other objects in sight, as well as songht for the eggs of eider-dueks, said to abound here. I was only able, on a moving pice of ice, to obtain the latitude, which placed us in $74^{\circ} 7^{\prime} \mathrm{N}$., the Devil's Thumb bearing nortli-east fifteen miles; shortly before midnight, the ship was secured to the floe.

About noon on the 24tl, the steamers having now become indispensable, they towed the vessels through a lead until eight P.M., when we seeured for the night,-or rather to afford the crew rest, for it is almost an absurdity to talk of nights during the summer in these high latitudes. "Midhight" however becomes a term of time; and at this lour a large berg, in rapid motion towards us, compelled us to again resort to our steamers, which towed us sufficiently out of its way, but unfortunately with the loss of two $\operatorname{logs}$, whieh, not yet suffieiently familiar to their new masters, and possibly over-fed, preferred anusing themselves on the ice to rejoining their ships. A boat and parties were sent to recover them, but without success. 'T'hey were again seen on the floeedge the following day, and the boat sent to endeavour to take them, but although food was taken to entice them, still with no better suceess; starvation, or the gripe of some lumgry bear, would probably very soon be their fate! Little as we knew these poor animals, still their loss was perceptibly felt. 
We had now reachcd "Nelvillc Bay," and the remarkable objects known as "Devil's Thumb," "Sugar-loaf," "Melville Monument," and Capc Walker, familiar to Arctic navigators, were all clearly defined, and apparcntly very ncar. But the positions on the chart, if they be truly plaecd-and we have reason to doubt it-would place us about forty miles from them.

June 26. - Lat. $74^{\circ} 34^{\prime} \mathrm{N}$., long. $59^{\circ} 23^{\prime} \mathrm{W}$. - Wc had a most beautiful day, the sun brighlit, temperaturc $36^{\circ}$, and wcre able to determine our advanee to have been about thirty-five miles north and twonty-five miles wcst during the last twcnty-four lionrs; we obtained soundings, with 320 fathoms; bottom, coarsc ground, with stones and coral. Our arrangements for "flitting," or deserting ship, in the event of getting nipped by the ice, wcre already made, and the necessary provisions for each boat stowed on deck in readiness. Eaeh person was supplicd with a bag, in whieh a complete suit and change of underclothing were kept stowed, so as to prevent confusion; officers and men were told off to their respective boats; in fact, every arrangement complete for leaving the ship in the most orderly manner.

I think I can perceivc the curl of lip of some fastidions fricnds, who may decm these matters absurd; but thcre is always an official mode in burning, sinking, blowing up, or abandoning a ship of war. Whatevcr happens in a well-disciplined ship, bccomes less inconvenicnt by evcry man knowing his duty; no confusion then results, and less loss of life or property is heard of.

It may appear strange, but doubtless it will be remarked in the course of our expedition, that "coming events cast 
their shadows before them." About eight this afternoon, the change of tide or eurrent set the westcrn ice in motion sontherly. As we had no wish to travel that ronte, our vessels were removed to the opposite or landfloe, and, as we thought, in a place of safety; indeed, the spaee of open water seemed to promisc us seeurity, and I had intended to remain quiet the ensuing day, Sunday, giving the erews their full day of rest. Shortly before midnight, however, I was informed that the floe was in motion and closing on the 'Resolute,' and that she would probably be "nipped." 'The others were all more in the eavity of the bay formed by the ice. Before I sueeeeded in gaining the deek, the 'Rcsolnte' was in agony, and had a considerable list (heeled orer'). The pudder in a few moments was destroyed, and the pressure then appeared to eease, - the floe brought up, possibly, by some opposition to the northward. The motion of the ice was almost impereeptible, but we lad now before us pretty conelusive evidenee of the nature of the heavy gripe which this insidions cneny was eapable of inflicting almost in dead calm. It was not a dircet pressure, but the grinding power of two mequal forees, aeting laterally in opposite directions. The best illustration to my fair readers wonld be to imagine the ship to be the roller of a mangle. The pressure strained the 'Resolute' a little, lifted her above her line of floatation some eight or ten feet; the bells were set ringing, glasses elattering. The sick did not eare to remain below; indeed, in a few minutes they might all belong to another vessel, and our noble consort hors de combat: and yet not the slightest noise or eonfusion, and no 
ap parcnt fear of wreck; boats and gear ready on the iee. 'This was a calm nip, and here it ended, with merely the loss of rudder; but had the onter floe been pressed by the addition of wind, distant, although not felt by us, and the "piling" of the broken floe commeneed, which result generally continues until all the weaker points have yiclded and the giants are firmly opposed by equal resistance in each other's embrice, the eonsequenees would probably have been serious. In very few minutes every rudder of the Squadron was unshipjed and liung to the stern-davits, and parties engaged eutting doeks for the vessels, a duty on which the ercws were engaged until nearly six A.M. About four the 'Resolute' was released, and docked with us; and as her rudder was found too much injured for immediate repair, the sparc one was got up, put together, shipped, and ready for service before the following noon.

I am aware that ny naval friends will require no explanation as to "docking" in iee, but landsmen may wish information, and, dry as it may be, I will endeavour to afford it in as few words as possible. I have already observed that the danger consists in being caught between the edges of two fields of ice in motion, and that, when these bodies come into contact, with a foree impossible to ealeulate, all weaker objects, ineluding the icy projeetions themselves, undergo "the crushing foree," until cqual forces overcome the eauses in operation. It must therefore be very apparent, that where sueh vast surfaees, miles in extent, are so firmly cemented together, if objects be sufficiently withdrawu into gaps within the line of their opposing vertical projeetions, they are safe. 
It is therefore customary, by the use of iee-saws, varying from ten to seventeen or eighteen feet in lengtl, from a quarter to half an inch in thiekness, and about nine inehes wide, to saw out a spaee whieh will admit a vessel twice her own length, and a few feet wider than her extreme breadth, within the irregular edge, and whieh will become completely sealed, should an adverse floe close its moutll; or, to refer very simply to every-day practiee, it is just backing up sone alley, if one is in the way of a runaway beer-dray in the Strand.

In the present ease we diseovered, even with three iee-masters in each vessel, and much other assembled talent and expcrience, that there is always much to learn, and moreover, to faeilitate any uneommon service, that method is imperatively required. Our doeks, construeted in haste, and without previous organization, were imperfect, and therefore we were eompelled to cut deeper, ineurring double labour.

As our men and officers were now stationed to each saw-gang, I had the opportunity, as this work was leisurely done by one watch, of determining the rate of work ou whieh I eould rely in ordinary eases. The average cutting of three-feet ice I found to be at the rate of ten feet in three minutes, whieh, if no obstaeles opposed, and there was external space into which the masses eould be floated, would allow of "cutting in" in forty minutes," or less, if danger threatened. Every officer" in eommand should, whatever may be the serviee required, estimate, nay determine, truly, the power at his disposal; and not until then is he eompetent to order, deeide on, or rejeet any contemplated movenent where time is involved.

* Later experiments: 1.40, docked; 1258 tons ice remored. 
In these onl early operations, recomrse was had to blasting, to aid the clearing of the docks. Charges, varying from twenty to four ponnds, were tricd; but the lenst possible quantity of powder which will cffect a crack, the more judicions. This is very easily nnderstood by any person endenvouring to extract by one cnd, and horizontally, a pane of glass from a sash : the entire pane may slide out freely, if whole; if broken at convenient angles, it nuay come out by pieces; but, if severcly cracked in ralii from the centre, it will be so much pressed at the sides as to require to be remored piecemeal. Ice is still more stubborn. I am fully satisfied that no man who really understands his business, and is not presscd for time, will call in the aid of gnupowder. It is highly dangereus to the dock-sides, which it generally splits, and causes to tumble to pieces the instant it becomcs relieved from pressmre. Blasting ice is in itself quite a distinct science,-as much so as flint-making, pebble-cutting, or geological operations.

But, in dealing in the theoretical points, I must not lose sight of the actual manceuvre, which is of itself quite an exciting speetacle. I lave before stated that method is indispensable; it therefore hecomes the duty of the officer superintending to have all his men duly stationed: an officer to each saw-gang and trinngle; the carpenter, with his crew, to line out the dock; and others ready to carry out any special orders of the elief. The carpenters line out a space of a wedge-shape, once and a half the length of the ship, say a humdred and eighty feet in length, on a middle line, sixty feet widc at the onter montli, and thirty fect at the inncr extremc. The side 
lines are then eut by the saw-gangs; and, as soon as they have fairly eommeneed, diagonal lines are followed up; triangles or jib-pieces (for whieh see Appendix) are slaped out, whieh are removed as ent. On the pipe "Doek ship!" the offieers with their saw-gangs immediately repair to their proper saws and triangles, and mareh off to the floe, two to the saw, two to the triangle, and four to the "gins" and "bell-ropes," in mueh the same order as artillerymen to their gun-gear, and await orders. 'The first few feet is a silent duty ; but "Now, my lads, for a song!" and at it they go eleerily, never forgetting those nearest their hearts, as "Sally is the girl I love so clearly," and similar improvised measures, eleering on the duty, oeeasionally interrupted by a simultaneous burst, or yell, from some, at least to us, unknown cause.

'The ieemen of the 'Resolute' eonsider that vessel to have had a very narrow eseape, and I perfeetly believe, with them, that no whaler eould have withstood the pressure to whieh she was subjeeted. The result has produeed a more serious preparation for "flitting," and greater attention to boat-fittings. What I had foreseen happened: a shift of wind set our floe in motion; the doeks broke up, owing to numerous eraeks oeeasioned by the explosions by gunpowder, and a general movement resulted. A polar bear approaehed the 'North Star,' but her sportsmen, too eager to get the first shot, fired before he was within range, upon whieh he very wisely withdrew from sueh uneourteons eompany.

June 30. - We had sueeeeded, after muels toil, in eutting and blasting through several necks of ice whieh separated the vessels, and were again eolleeted, when the 
wreek of a ressel on the iee was reported from the erow's-nest. It was then so foggy that we had been groping our way along the floe-edge, in order to prevent the possibility of parting eompany. On reaehing the wreek, whieh we found to be still suspended with her bow ont of water, by lier easks and air contained between deeks, I eaused the vessels to be seenred to tho iee, and eommeneed saving all the available firewood, of whieh we were in need. By bits of papers and brands upon her' spars we diseovered that she was the "Regalia,' of Kirkealdy, and had but reently been aban-doned and set on fire. The hacking of her spars, rigging, ete. appear to have been exceuted by the most malieious fecling of preventing others from making use of them. The fires were still burning, and it was evident that the erew had not long quitted. We sometimes laugh at the rapidity with whieh wreekers destroy and earry off property; but in a ver'y short spaee of time the masts, yards, rigging, ete. of the late good'ship 'Regalia' were absent, and stowed somewhere on board the five vessels, whieh "had not room for another eask of prorision." As the lull, in its present position, might endanger some other vessel, I determined to let her go down, and, at the same time, relieve her of some of the casks and staves within. 'This, one of our twenty-ponnd eylinders of gumpowder very effeetively aeeomplished, strewing the surfaee of the sea with the remnants of easks, staves, ete. At this moment our men were at dinner; but the noise of the explosion bronght them up, and

* "Crow's-nest," a look-out place, about the size of a cask, constructed at the topgallantmast-head, to watrh for whales. 
from each ship the boats' erews rushed, as eager for spoil as any of our Sooloo friends: it was diversion, excitement, or that innate habit of mischief and fun implanted in all seamen, for to them no value eould attach to these spolia opima. It furnished food for eontemplation, of a very mixed character. But a few honrs sinee, such might have been the fate of the 'Resolute,' and, in less time than it takes me to commit this to paper, may be our own!

Whilst thus engaged, the fog elcared off, and discovered a ressel mucler sail to the westward. About four P.m. the 'St. Andrew, of Aberdcen, joined, and I there found part of the crew of the 'Regalia,' who informed me, that if we had hove in sight, we conld have saved a great part of her bread and provisions, which would lave been most valuable. She had been nipped ten days before, the ice passing entirely tluough her, meeting at the main hatchway, or, as they termed it, "completely toggling her." The master having given up cliarge, and released the erew from further obedicnee, encli boat-steerer, as eustomary, took his boat,-and having provisioned her, the erew then broke into the spirits, and, regaling themselves in the cabin, at their highest piteh of intoxication, ordered the skylight to be closed to keep then warm, when the least motion of the iec might have sent them in an instant to their last reckoning! This was succeeded by every wanton act which nuadmen could commit. A fire was made upon the rudder lying flat under her stern on the ice, and the slip burned until that end of her sank, leaving her floated merely by the air eontained in the bow and 
empty easks in the fore-lıold. We gave the 'St. Andrew' a tow 11p to the whaling flcet, whiels we diseovered that afternoon, doeking in eompany with thirteen, about ten o'elock that same evening.

'The great floe of Melville Bay, where we were now seeured, deserves some little notice. Enlivened, as at present, with a forest of mists and aninated beings, its wilderness is not sufficiently eontemplated. But let the solitary vessel be there imprisoned, and eompelled for weeks, without a eonsort, to anxiously wateh every elinge, night and day, whieh may afford her the slightest chanee of getting into the "north water," and every inspeetion must impress upon the mind the dreary monotony of that floe! As far as the eye ean range, a painfully white, even surface prevails, here and there broken by a luge ieeberg; or where mounds of erushed ice or nips present themselves, piles of rubbly irregularities, like luge paving fligs, eause the mind to dwell on the stupendous power engaged. The eyes beeome painfully affected by the glare, partieularly when the sun is bright. The iey surfuee is generally eovered with a fine slieet of suow, or, at times, fine eomminuted drift iee, whieh on elose inspeetion will appear to resemble hailstones.

'This floe-eovered oeean varies in the thiekness of its sheet of iee from two to seven feet, and, where pressure las taken eflect, is frequently doubled or trebled by alternate flakes pressed under by the neeting of eonflieting floes. It is owing to the pressure of linndreds or thousands of acres against the land-fast iee, eatehing a vessel ninprepared by doeking, that these fatal "nips" result.

The eomputation of the floating weight simply of a surfaee three hundred yards squire amounts to 63,080 
tons. With even this insignificant floe, impelled by wind or tide against the frail wooden strueture of man, what can avail?--something like the Nasmyth hammer on a nut!

If the vessels intended for the whaling trade were built witl a more wedge-shaped bottom, the ice in many instances wonld merely raise them out of water, and allow them to regain their floatation when it eased; but she would not then hold the eargo which gain requires.

Strong, however, as the 'Assistance' is supposed to be to withstand pressure, I much doubt whether we should come off so well in the event of deeided "nip" as many of the vessels here. Te are deep, heavily laden; they are light, withont eargo, would rise easily, and evade the death-gripe, when we should be erushed.

I much fear that my readers will exclaim, "This is merely a book of disasters : another wreek!" But too true; and this time an unfortunate American. On the 6th of July, ill one of those animated moves, when crely effort is exerted to get ahead and obtain "the lead" through momentary openings in the iee, the 'M'Clellan' barque, being in advanee, endeavoured to pass a narrow opening, in order to reach the next "lead." She had nearly suceceded, but the ice, changing its motion, canght her in the narrows, "nipped" and liurt her badly. In a very short time she was deserted by her erew. On this oeeasion our erews aided, repaired, and left her, as we deemed, all safe, and her crew were indueed to return. But hardly were we all seenred in doeks, and I was congratulating myself in having thus saved the ressel of our' ally, when it was reported "that she lad experieneed a fresh nip, was driren on to the bow of the "North 
Star,' carrying away her cat-head; and that further assistanec was required." Commander Pullen further reported, "that he momentarily expected to lose his bowsprit, if further damage did not result."

Fatigued as our crews were, there was no alternative: all the available hands from the Squadron were sent to the 'North Star ;' and the master of the American having abandoned his vessel to me, possession was taken, to save stores, protect property, and to prevent any mad action of the wreckers, which might endanger H.M.S. North Star.

It is unneeessary for me to narrate all that was done. I adopted such measures as seeured the 'North Star' from injury, saved a considerable quantity of bread from the ' M Clellan,' and eventually allowed the vessel to go down.

The floc about this period presented a very interesting subject for the painter. Several of the whalers were experiencing very deeided pressure from without, and astern of these ressels would be seen the various "flitters," boats, sails, provisions, etc., with the crews idly and unconeernedly awaiting the result. The Americans too had not yet selected their vessels, and werc, with their boats and chattels, on the floe, slceping however on board different vesscls.

One fact however, totally unlike the old breed of English scamen, I was ashamed to witness,-the childish apathy, or worse feeling, which seemed to pervade them at the moment when their scrviees were most required, and when thcir exertions might have determined the safety of their vessels. No danger to themselves presented; yct all subordination appeared to cease, whenever one boat-stecrer chose to takc liis boat to the ice. 
I mark his, because I think it is this vicious principle of making the boat his, , and joining another vessel with her, that couses all this precipitate abandonment, insubordimation, and loss of vessel

In the casc of the 'MrClcllan,' the first act of the boat's crew of the 'Regalia,' shcltcred by her, was to set the eaptain at open defiance, and her own erew would not put a finger to the work. I firmly belicve that if Her Majesty's ships had not been prescnt, sad outrages would have been committed.

I cndeavoured to induce the masters of the whalers present to embark part of her cargo of oil, ctc., saved, with salvage allowance; but all refnsed, declaring that by their law (that of the floc), all that came over their gunwale was the property of the ship. It is on this principle that they destroy their vessels. The oil then floats; they could take it on the sea, but not from wrcck. For the provisions, fuel, etc., I agreed that Her Majesty's Govermment would pay the owners, on production of my reccipts.

About the 20th of July, the whalers laving come to the resolution of going south, and not losing more time in trying the uncertainty of Melville Bay, or gaining the "nortll water" by this ronte, our letter-bag was despatchicd by the "Truc-love.'

On the 2lst, they grachually stole away, leaving us in quiet possession, the 'Alexander' alone detcrmining to stick by ns, and to take our latest despatclics. The fecling was gloomy, but as the separation directed our energics to our own immediate duty, I was not sorry to

* Why not pass a law to make it piracy to take a boat without the master's signature and full consent? 
be alone: indeed the companionship and ship-visiting did not agree witl ny notions.

On the 23rd, the lanes appeared to have been for nearly sixty hours gradually widening; at times the shcets of water broad, and apparently free. Our progress, however, just as we had almost caleulated our hours to Beechey Island, became suddenly arrested by fog. 'The ice also closed in, compelling us to dock; the 'Resolute,' 'North Star,' and 'Intrepid' were lost in fog, but not far distant, as we could hear their return-guns plainly.

July 24.-In $75^{\circ} 36^{\prime} \mathrm{N}$., $61^{\circ} 5 \mathrm{l}^{\prime} \mathrm{W}$.-Toiling, towing, and blasting the iee, until eight r.u., when we made fist for the night; about midnight, on the fog clearing off, we discovered the other resscls, about four miles distant to the sonthward. Being now so far asunder, and the chanees of their taking a different lead probable, I made the several rendezvous, pointing out Capes York and Dudley Digges as the two first.

July 25, Sunday.-Quiet as any Sunday could be wished; we distinctly heard the bells of our consorts over the ice, and, having measured base by guns, found the 'Resolute' to be four miles distant.

On the $27 \mathrm{th}$, about midnight, we lost sight of our consorts behind some bergs; they were, at the time, apparently free, and procecding rapidly by the in-shore lanes. We ran alongside an iceberg, to water from a pool on its summit, effecting our landing on the berg from the foreyard; but the floe threatening to close and press us on the berg, we were compelled to haul off, beforc we liad completed.

'The 2Sth found us moving on ehecrily; open water' and plenty of room. A bear was discovered on the floe, 
to whieh we gave ehase in the gig; the simpleton foolishly took to the water, and gave us a very smart pull; however, poor fellow, he soon diseovered that he was not in his element, and sprang upon the first small floe-pieee he inet, where he took his wounds most eourageously, plunging again into the sea to allay the pain. After a very animated ehase, and some very bad shots, the balls finding their way to the ship instead of Bruin, le surrendered, turning up suddenly on his back. This was the seeond killed in Nelville Bay, the first by Commander M'Clintoek and Lieutenant Meeeham, of 'Resolute, on the 6th instant. This animal, even after a ball had passed through his brain, I was informed by Lieutenant Meecham, was disposed to show fight!

July 29. - Our advanee had now beeome pretty regular, oeeasionally impeded by sudden meeting of points of floes, but these were soon overeome by blasting. I left the ship today for a short time, with Lientenant May and Mr. Grove, in pursuit of the rotges, small aquatic birds (Alca Alle) about the size of a water-hen. We killed one hundred and fifty; but in the aet of pieking np the dead birds, a sudden rmo of the iee took plaee, at the rate of three knots, driving many of the birds under the sharp ledges of the floe. We killed between five and fifteen at a shot. 'The ship and 'Pioneer' were temporarily pressed against the floe, but it soon eeased.

On the 30 th, we had reaehed $76^{\circ} \mathrm{N}$. and $63^{\circ}: 29^{\prime} \mathrm{W}$., and elearly on the verge of our long-desired "north water :" Cape York was in sight, and, towed by 'Pioneer,' we were pursuing our eourse merrily, hoping to rejoin our eonsorts there, not doubting but that they had been more fortunate in getting along the land tham ourselves. 


\section{CHAPTER III.}

Native Dogs.—Red Snow._Cape Dudley Digges._Game.-Cape

Warrender.-Beechey Island.-Rejoined by Captain Kellett.-Cape Riley.-Find Pieces of Whale.-Parting Ceremonies.-Wellington Channel.—Queen's Channel.-Mount Perey.—Winter Quarters.

July 31.-During the night, we had been making good progress, threading the mazes with facility, although orcasionally bewildered by fog; but as the sun gained power, this gradually gave way to a beautifully clear morning, and before eight we were able to distinguish the huts of the natives under Cape York: no traces, northerly or southerly, of our consorts. Rumning close under the southern side of this high cape, we noticed the sledges driving down to the floe-cdge, and, accompanied by Dr. Lyall, I went in the gig to visit them, taking presents of knives, scissors, needles, thread, looking-glasses, saws, beads, etc. It was at this Cape that Captain Ommanney examincd for traces of Sir J. Franklin, and bronght away the native boy called Erasmus York. I much regretted the absence of the Esquimaux vocabularies, none having bcen supplied to this Squadron, and therefore was totally unable to make them comprehend that three other large vessels were expected ; they betrayed no signs of having

VOL. I. 
seen them. As to inquiry after E. York, they no doubt considered him sold as a slave, and turned their attention more to the busmess in prospeet. But one old man and a boy met us at the floe-edge, the others, although near, having held aloof, in all probability waiting until they were apprised of the turn of affairs. Our traffie with these people, who were filtly in the extreme, eannot prove interesting. In return for om presents, bnt more particularly in exehange for a boat-hook and a broken oar, we obtained threc very fine and handsome native dogs, not differing a hair in marks or eolours from eaeh other, being of an iron-grey, whitish beneath, dark stripe on baek and shoulders, and strongly resembling a very dark-eoloured Aretie wolf.

I was indeed glad to find that the artieles whieh they preferred were likely to be of sueli value to them, instend of the trumpery gewgaws usually given to these uneivilized beings, As to looking-glasses, if I for an instant imagined they would refleet their own deformities, and induee them to mend, wash themselves, or to serape off their filth, I would gladly have bestowed on them all our supply, Of wood they appeared to be greatly in need, and had I been aware of it, before leaving the ship I would have given them some of great value, viz. the staves of the great oil-easks pieked up from the wreeks. Eael of the sledge-rumners I notieed, were eonstructed of no less than nine pieces of oak, partly staves and lieads of easks eleverly sewn together, and probably belo ging to some vessel wreeked, or proeured from the 'North Star' when she wintered a short distanee to the northward in $\mathrm{Wol}$ stenholne Sound. They were evidently aeeustomed to 
the visits of English, the boy in partieular-a mueh more intelligent lad than York, and very playful, freqnently repeating "Yes, yes." 'Their tents were pitehed on the low ground, under the southern and inner slope of the Cape, whieh is probably about five hundred feet elevation; but we had seen quite enongh of the individuals, not to eare about inspeeting their labitations, and I had yet to reaeh the Cape in time to seeure observations for time and latitude. On our quitting, several parties joined our friends; and we moved off, direeting the ship to proeeed towards Cape Dudley Digges, and, if not overtaken by us, there to await my arrival. At the time we landed, eider-duek (Anas mollissima), lummes (Uria Brünnichii), dovekies (Uria Grylle), rotges (Alca Alle), gulls, and other sea-birds, were numerous, and the narwhal (1Conodon monoceros) was sporting in great numbers.

I omitted to observe, that the rotges shot by us appeared to be absolutely gorged with a small deep-red shrimp, whieh probably renders the flavour of these birds more palatable than those subsisting entirely on fish. And it frequently oceurred to me, that the tinted spots in our vieinity, termed red snow, had some eonneetion with these birds, whieh build their nests in the eliffs immediately overhanging; and the floe, far from this region, was repeatedly notieed as tinged by them, but eertainly not of so bright a lake or erimson as that now notieed by us in this loeality, whieh is not given for the habitat by Sir John Ross; nor did we notiee it to prevail mueh between this and Cape Dudley Digges. A supply of both (ocemring together) was taken, and preserved for future examination. 
The latitude of Cape York was detcrmined to be $73^{\circ}$ $53^{\prime} 47^{\prime \prime} \mathrm{N}$., and the variation $90^{\circ} 4^{\prime} \mathrm{WV}$.; but we were too late to determine, with any degree of precision, the longitude. It agreed with the observations taken on board. But the coast-line, as placed on the chart, is certainly erroncous, as it makes it convex; whereas I plainly saw Cape Dudley Digges, and all the intervcuing points, in the concave, as wcll as the unnamed island, off, from my position. Several wild flowers, including poppics and saxifrage, werc in bloom, and the base of the cliff was wcll clothed with abundance of long grass.

Wc regained the ship, about three miles to the northward of Cape York, and had full time leisurely to examine the const with our glasses, as we were slowly towcd by the 'Pioncer.' Where Beverly Cliffs may be, I know not; but no crimson snow now marks the spot.

Towards midnight, we neared Cape Dudlcy Digges; and as this was the second rendezvons, I landed to erect my beacon, lcaving instructions to Captain Kellett to follow to Cape Warrender. It was a cold and dreary job, and, but for the noisc of the disturbed birds, which have their nests here, might be pronounced awfully solemm. It was very difficult to find any position on the profile of such a vertical bluff which would conspicuously exhibit my mark; by dint lowever of scrambling, we found a ledge well suitcd to the purpose, on which a whitewashed cask was placed, and filled with stoncs, our cylinder being suspended within rcach from a lowcr level. This complcted, I was not sorry to regain my boat, and find myself, after twenty honrs' exertion, on my way to my nest. Some few lummes and dovekies 
were added to the larder, and a very fine burgomaster (Larks glancus) was winged, but he fluttered so far to lceward that pursuit was not warrantable.

Cape Dudley Digges is a lighl beetling bluff, elevated about eight himdred feet above the sca, and of a porplyyritic character. About five niles north-west from it is a ligh-peaked ummamed island, termed by some of our men-not inaptly-Desolation Island. Off this I rejoined the ship, whieh, by the reckoning, would place this island north-west five miles from Cape Dudley Digges. I cannot imagine that our consorts have passed, or some sign would liave been left.

Before taking leave of this region of birds, I would wish to record my observations upon the probability of Sir Joln Franklin seriously thinking of laying in any supply. It is not improbable that they did so for private purposes, or for the nse of the sick. But any man traversing latitudes within the Aretic Circlc, will be perfectly aware that no salting process would be necessary, where nature takes much more efficacious means, by reason of low temperature.

They are not so easily killed, or taken when wounded, as some nay be led to believe; and with four donblebarrelled guns, in onc lour, but a hundred and fifty were captured, and get they swarmed. But I very much donbt any one killing them with peas, ccrtainly not with "split peas," with which I think Sir Jolm Franklin's and other Arctic vessels were supplied. Nor would any rational person so wilfully throw away "pearls after swine," when abundance of shot was provided by the Government.

But wishing to determine, in the distribution of birds 
killed on service, what would be deemed a fair equivalent as compared with meat, I directed a committee to report thereon. The result was, that twclve of these birds (Alca Alle) werc not deemed more than adequate to one pound of meat. This, then, reduces the question to one of numbers: $12 \times 90=1080$ per diem would be required, to afford the crews of the ship and tender with one meal. It is my conviction that, taking a boat's crew, or even two, of our picked men, fit to be trusted with sporting, this number would not be taken in onc day, and the opportunity never probably to be repeated. But a much more important matter hinges on it. His vessels, we know from the letters received, were fenrfully hampered with coal and provision. Where were they to stow some humdreds of thousands? Moreover it is too doubtful an experiment to try upon a crew, situated as he was, to force them, before necessity rendered it prudent, to take a substitute for provision. When birds are issued, it generally is considered in addition, to checr them, to keep up their spirits; or when game, as decr, musk-ox, ete. can be substituted entirely, or lialf with half rations, on the march, and where they eat as much as they require, no bad fecling would ensue. But the result in my own ship was, that I did not consider it a safe experiment : it was not necessary, and therefore the birds, when we had killed sufficient, were served out as additional.

August 1.-Lat. $76^{\circ} 3^{\prime} \mathrm{N}$, long. $70^{\circ} 46^{\prime} \mathrm{W}$. - Weather very fine; light breeze; the horizon clear, blue, and well-defined, dotted merely herc and there with small icebergs; the eye much relieved from the late painful glare of the ice; and the good ship, under canvas and in torv, 
gliding smoothly along at the rate of 3.5 knots. After our late dreary eonfinement in the floe, this was indeed felt as a release, - we breathed freely on our own element. Nothing now was wanting, to eomplete my satisfation, but the sight of our eonsorts, alead or astern,-the former preferable, as our single steam-tug would soon bring us up with them, at all events, long before we required them in aid of our operations. At this position, I notiee that my friend Austin was, on the 14th of August, about ten miles north-north-west of our position; so that we may eonsole ourselves, after all ou tedious delay, that we are at least thirteen days in advanee of his expedition,- - amounting here to nearly half a season.

Notwithstanding mueh was advaneed against the propriety of our early departure from England, I now feel fully satisfied that we were still as late as eould be ventured. We have gained greatly in strength, in aptitude for iee-scrvice, and generally better aeelimated than if we had made the most rapid progress from the mouth of the Thames to Beeehey Island. There are also many minor, but very important eonsiderations, to whieh it is umneeessary to revert, relating prineipally to the general health of the erews, of whieh my mind has been but lately relieved; and this delay has considerably enlaneed the value of some individuals, who might otherwise have been deemed fit subjeets to be sent home. But we are now in full vigour, ready for any scrvice, and in good training.

On the and of August we had reaehed the lat. $75^{\circ} 5^{\prime} \mathrm{N}$., and long. $73^{\circ} 21^{\prime} \mathrm{W}$., and but few spots of iee visible. These steamers arc certainly better than nothing, but are unable to tow us more than three and a half knots, under 
every assistance of eanvas; and at very critical moments, owing to want of power, are under our bows, or possibly foul the towing hawser. Vessels for this service should bc independent serew steamers, accompanied by the ships as transports or depôt vessels. 'The officer commanding should bc in the steamer. Hailing and straining the lungs to pcople always half dcaf, is not pleasant to cither party, and is productive, by repetition of orders, when not heard or not obeyed, of very unpleasant feelings. 'I'owards the evening, the breeze having freshcncd considerably, reducing us to close-reefed topsails, wc east off the tow-rope; motion quick and unpleasant, and ship dropping away to leeward vcry fast.

On the 4th we were again enabled to make all sail, but found wc had been driven, by current, to the soutlward of the entrance of Lancaster Sound, making Cape Walter Bathurst, in lat. $72^{\circ} 19^{\prime}$, long. $76^{\circ} 20^{\prime} \mathrm{W}$. It is needless to dwell on our misfortunes, or the time taken to recover ground; I shall thcrefore assume my position off Cape Warrender, on the 7th, whenee I despatched Commander Riehards to the Capc, to examine for rccords, and sent the 'Pioncer' off to Navy Board Inlet, to report upon the coal and provision deposited thcre by the 'North Star.' At Cape Warrender Commander Richards left my despatch for the Admiralty, as well as one for Captain Kellett, but could not find the document left by Captain Ommanney. The label of the cylinder, with "Pull out," was found,-apparcntly intclligible to foxes, as the impression of their tceth was ummistakable. There is, however, from later intelligence from Commander Inglefield, strong ground for believing that not only 
this, but my despatehes deposited there, were earried off by Esquimaux, whom he met with at Dundas Harbour, a little to the nortliward, in the summer of 1853.

Captain Kellett evidently had not ealled here, or he would have left some intelligenee. Onr progress, unaided by the 'Pioncer,' and eontending with adverse wind and tides, was very slow. 'The weather was beautifully fine, and we anxiously looked out for the return of the 'Pioneer,' whose absenee was now very protracted. We had too mueh spare time to admire the extraordinary singularity of the entire land eomposing the northern side of Lanenster Sound. One very impressive idea is almost foreed upon the senses, and that is, that one line has been common to the entire summits, and at one period the surfaee must have been eontinuous, exhibiting an immense surfaee of table-land, and this, the original fenture, was probably level with the ocean ; that, either at its up-heaving, or on the subsidenee of the waters, it left parallel terraees for hundreds of miles, and the eseape of the water ehannelled deep ravines, or seooped out deep bays, constituting the prescnt castellated eminenees. Subsequently, I am led to add-Nor is it to the eye alone, as viewed from the deck of the passing ship, that these ideas are solely formed; it will be notieed hereafter, that a similar eourse of structure, similar roeks, fossils, ete, pervade this strange region, even to the extrene exploration north of this parallel. By dint of standing elose in-shore, and watching every elange of tide or wind, we had just gained a position to enable us to "lie up" for" Beeeley Island, and the breeze eontinued to favour us, when our euriosity was exeited by report from the erow's-nest of a stranger 
in the dircction of Leopold Island. Many were the conjectur'es; for 'mnder' some aspect, totally inexplicable to us, did this stranger present herself distorted by mirage. The black pendant soon informed us of her moving power, but the 'Pioneer' it was not; onl suspensc was not of long duration, for the 'Intrepid' made her pendant, and soon took us in tow, when I learned that our consorts had reaehed Beeehey Island, and not having ealled at our places of rendezvons, the 'Intrepid' had been sent to look for $11 \mathrm{~s}$.

Auguest 11.-On the morning of the 11th, intending to visit the cairns en route, by pulling ahead in the gig, I went on board the 'Intrepid;' but almost at the same instant, noticed a large bear about to visit the very cairn to which 1 was proceeding. A very short signal to the ship sent her sportsmen to my aid; and landing full in front of the cairn, whilst the officers took it in flank, Bruin came down to meet me, and was duly complimented by both barrels. He seattered along in-shore, and fell under the accmmulated wounds of those who met him in retreat. 'This animal was towed on board, weighed $757 \mathrm{lbs}$, and measured eight feet seven inches from snont to tail. Having examined the reeords left at Cape IIurd by Captain Austin and the American Expedition, we moved forward; however, adventnres never happen singly. Shortly after noon two walruses were noticed on a floe-piee in our conrse, and the harpoongrm put into reqnisition. The effect was beautiful ; passing the harpoon through the monster, and that without leaving him power to get off the floe: it was a dead shot. IIis eompanion made a great fuss abont it, was treated 
witl several balls, but eventually retired. This, added to the bear, beeame a most valuable acquisition to our dogs' food, which had now becomc very nearly expended. Shortly after five P.s. we sighted the 'Resolute' and 'North Star,' seeured to the floe muder Beechey Island, and before seven the 'Assistanee' was also fast beside them. When Captain Kellett eame on board, to report procecdings since our separation, I found that he had reached Cape lork, and eommmineated with the natives, on the day after, or the night sueceeding, my visit, but had not the slightest intimation of their having been visited by us; and strange enough, he saw the boat-hook which I had presented to them. As he did not eall at Cape York, Cape Dudley Digges, or Cape Warrender, he had not net with my notices, nor knew of my having passed those stations.

On the 12th Angust, accompanied by Captain Kellett, and also by an official party under Commander Richards, a elose seareh was made of every likely spot on Beechey Island, but without discovery of further traces. The graves were dug into, but found so firmly frozen that no prospeet offered by further disturbanee; they were therefore replaced, and completed anew. Upon viewing the spot carefully, I was strongly of opinion that the ships under Sir J. Franklin did not winter on the southern side of Beechey Island, but were in Union Bay. ¿pon a very carcful review of the ground, there are several points, which must lave oceurred to Sir John Franklin and his talented seconds, which, in my mind, would have prevented them from selecting the sonthern bay. In the first place, it was at once the opinion of Captain Kellett, 
Commander Pullen, and myself, that Erebus and 'Terror' Bay was not a safc position for the 'North Star,' and we determined to seek a better, if possible. Next, if the "North Star' should have to "cut in," there would be great doubt of her getting out until very late in August, or by the 1st of September. 'I'his could not suit the views of Sir John Franklin. With Union Bay the ease is quitc different, and the ice may be eut or blasted, by watching convenicnt moments. For two scasons we know that it was free; and now it is all but clearing ont, any aid would send it forth; but great labour would be required to cut in or out, to where the 'Erebus' and 'Terror' werc supposed to have been. Sir James Ross landed the 'Mary' yacht on the beach of Union Bay, when Erebus and 'Terror Bay was as fast as at present. But the most convincing evidence to my senses is, the drift-lines of oakum, clips, ete. on the southern bend of Union Bay. I found also in the washhouse (so termed), but which I consider more likely to have been an hospital, similar threads of oakum from the seams of somc vessel, with the piteh adhering; but on the curvature on the inncr, or Erebus and Terror Bay, no drift whatever was noticed. Everything at the Point indicated that to le ncarest to the ships, - the pile of preserved meattins, the garden, etc. No direction-posts were notieed but on the north and south lines of Union Bay. All operations discovered arc on that coast,- - nothing on Beechey Island, cxeepting the sheltered spot for forge and workshops. So perfectly convinced did I feel upon this matter, that whilst we were examining the drift on the beach, I obscrved, "Well, lct us send two hands across 
the ice, to mect us at the point where we strike the bay, and direct them to search the intervening beach for driftmood." On reaching the spot (the north bend of Union Bay), I found two pieces, one Canada, the other English elm. The men lad found nothing.

Proeeeding on, we visited the 'Mary,' left by RearAdmiral Sir J. Ross, and, having taken an inventory of her contents, moved on to ascend Cape Spenecr, hoping from thence to obtain some insight into Wellington Channel; but in this we were disappointed, the ligher land in rear intervening. We examined the notices, rebuilt the cairn of double dimensions, and returned, somewhat fatigued by one day's labour. I had despatched Commander N'Clintock, in the 'Intrepid,' to report upon the state of the iee in Wellington Channcl; but the reports of all the visitor's to the leading headlands, which afforded any vicws up the channel, were rather adverse to open water; some even fancied they saw the icy barrier across the straits.

Today, the 13th, we devoted to the examination of Cape Riley and Gaseoigne Bay, accompanied by Captains Kellett and Pullen. We first proeeeded to Cape Riley: the result of our search afforded no clue. The cireles of stones were clcarly those of Esquimaux. The huts lad not becn temporary habitations; each was perfectly paved, as in regular settlements, and, as is customary with these peculiar people, the slabs had been brought from some distance, as the fragments under the fallen cliff were abrupt, rhomboidal masses, but these were selected tabular slabs, particularly at the graves, misnamed fireplaces. The same loose stones, used by the Esquimaux to steady their tents, might lave been used by 
Franklin's peoplc. I very muel regret that the articles had not been found by us. I am not presumptuous enouglı to fancy I know more than others, but there is a sort of frcemasonry in men accustomed to distress, which enables them to read the movements of othcrs, induced by the recollection of what thcy have themsclves practised. Such a feeling has ever remained fixed in my mind; but several important questions arise. What tents do we know of laving bolt-ropes? Why would they cut them off? But, on the other hand, I have had to cut up my sails, to make sandals for my men! Again, for what use was that rake? Not to take objects of natural history, but to detach the edible fuci, which my men and officcrs have repeatedly secn me seck, and eat with satisfaction. The inner low-water beach and rocks, immodiately under the point at Cape Riley, furnish this fucus (dulse).

Captains Kcllctt, Pullen, and myself have had somc little practice in magnetic observations, and we were unamimously of opinion that this station never was seleeted for such service, or, if so, very injudiciously, as the vertical mass of mountains overhanging would prejudice any results obtained. In plain tcrms, I believe that some accident occurred there; and possibly they had to cross the bay, to regain the ships, if they were there. Another argument against tents is, that thcy are supplied by the Ordnanee, are not of canves, and could not have the service-mark in their four-stranded cords or lines.

'This then must still remain clonded in mystery. Another consideration forces itself on the minds of men who work in these tempcratures-At what season would thcy propose to make their magnctic observations? Not at all 
probable in August, when Franklin would be bound up Wellington Channel, or homeward; and only in August, or later, when thaw had removed the iee, would we find men groping, with savage adaptation of rakes, in searehing the bottom for objeets of natural history: one of three objeets only plaeed them there-game, amusement, or distress; I fear the latter. I eamnot, painful as the conelusion is, divest nuyself of the feelings which werc impressed on my mind on searching that so-called washhouse. The indelible features of a entastrophe were there: painted eanvas, panels, mouldings, oakum from the side-seams of a vessel (wide seams too), pill-boxes, surgeons' phials, rags, - all indieated a house of shelter or hospital; moreover the internal inelination was falling to the eentre, as if the easks had formed the side barriers, and the sleepers had slept with their feet towards the eommon fire. Now, taking into eonsideration the earliest moment that the ships would embark observatory tents, and with tent-pegs, any ground into whieh they were driven would yield them easily in Jume, July, and August. I ask, what hurry? And again, in colder months, what would they be employed about in tents? and then, whenee the eonfusion? They eould not get out in July. Indeed every suggestion of hurry is absolutely untenable. A eollection of the artieles found was piled up, and ordered to be preserved, and unfortumately was not attended to; for', to my mind, the most important artiele, the oakum from the seams, was lost."*

* These remarks were penmed in August, 1952. I see no reason to alter my opinion now, in 1855 : I still believe that position to mark a disaster. 
However, I shall now dismiss this subject with Cape Riley. Fossils abound there, particularly fine specimens of the lily encrinite, but the operation was too laborious to procure any connected speeimens, the rock splitting to pieces inder the slightest eoncussion.

Moving on towards Gascoigne Inlet, we noticed a bear in distress, that is, puzzled, not knowing how to proceed without confronting us. They are not courageous beasts, and fly from man, if escape is ever open; but this poor unfortunate gentleman was perched at the top of a steep débris clute, which had a steeply inclined corresponding glacier on its left. There lie stood, as we suddenly came upon him, and most measy were his movements, - he paced his quarter-deck in agony, Captain Kellett and myself landed; we both fired from below, and wounded him; 1 then aseended by the débris, backed by my boat's crew, with boat-hooks, etc., and got upon his level, when one ball settled his fatc. Poor stupid creature!never call them cunning nore! His den was bcneath lim, under this glacier, where he might have snugly ensconced himself and laughed at us; and into this refuge did he now try to crawl, as he reecived his death-wound. We should have been glad of the aid of Gojdon Cumming to extricate this monstcr, as it was no easy matter to pull him out by the hair of his hinder extremities; however, having got hold of one hind leg, he was soon gliding down the face of the glacier, faster than on any "montagne Rnsse," lcaving us very little trouble to get hin over the remaining iee into the boat.

Our examination of Gaseoigne Bay did not prove satisfactory. 'There was not sufficient depth of water' for the 
'North Star' to lie secure, even at its mouth; no shelter from the ice of the strait; and, from the thimness of the floe, it would inevitably break up with the first breeze, leaving her quite exposed to the driving pack. It was therefore deeided to eut into Erebus and Terror Bay, where very strong ice still prevailed, notwithstanding some of its outer lines were constantly breaking away. As we neared our ships, I noticed that something unusual was taking place, as the mollymoks and gulls were dashing at picees of floating matter, with whieh they were gorging themselves in a most excited manner. I determined therefore to ascertain the object of so mueh eontention, and, nuch to my astonishment, found the floating pieees to be the outer (or blubber) parts of the white whale, cut into pieces of eighteen inches to two feet square, and evidently by some sharp instrument. Two pieces were taken on board, to be reported on by the iec-quartermasters (whaling-nuates), who pronouneed them " to have been cut by some sharp instrument, and that they were recent and sound." I could therefore only attribute them to some visit of the "Prince Albert." *

The 'Pioneer' having returned, and Lieutenant Osborn reporting that he had been unable to find the provisions at Navy Board Inlet, every effort was made to complete her eoal from the 'North Star' that evening.

On the afternoon of the 14th of August the 'Intrepid' also returned, her Commander reporting "open water as far as he had been able to examine, but patches of iee in several direetions in our route." 'The leading officer's dined with me, and after reading over the several instructions

* This question has never been cleared up.

VOL. 1. 
for their guidanec during our separation, our despatehes and last letter-bags for lome were elosed, and delivered to Commander Pullen, in the hope that the 'Prinee Albert' might stray this way on her homeward passage. And now a very painful and exeiting duty remained to be performed. 'The crews of the Squadron having been colleeted under the Union, on the floe, were addressed on their several duties. The beautiful prayer eomposed by the Rev. H. Lindsay, for the eommeneement of travelling, was read, and a copy distributed to each person. After many and some very warm expressions and pressures of the hand, we parted to our several duties, Captain Kellett remaining with me to the last; for in sueh a service there are many last explanations. But on one point a most fervent determination, "God willing," was exehanged, "to communieate in $77^{\circ} \mathrm{N}$. and $105^{\circ} \mathrm{W}$." About eleven P.M., all our arrangements being eomplete, I took leave of my eompanions; and as they passed over the side, the order "Let go the warps" was issued. Towed by the 'Pioncer,' we slowly moved forward, cheering and cheered, until the island intereepted further communieation.

We were now entering the threshold of the contested Wellington Channel. Anxicty, deep anxiety, oppressed me; it was mmixed with doubt,-rather the reverse. Through that ehannel my eourse lay. If any explanation of my feelings could have been reaehed, possibly it was nearer to gratitude that Providence had enabled me to be the humble instrument by whom it was to be explored.

By midnight our entranee, to my mind, was no longer doubtful: no trace of opposition,- - the elear, deep blue 
sea, visible to the horizon, was before us, and, refleeted in the heavens beyond, the well-known "watel" sky" afforded us the eheering lope of passing the Rubieon, the icy barrier of Penny, at Cape Osborne. Every foot advaneed raised emotions not to be explained, and the teleseope had but little rest, so eagerly did we sean every feature of the surrounding eoast-line.

On the morning of the 15th, a small eairn was notieed on a point a little ahead; I quitted the ship in the gig to examine it; it was Cape Grinnell, but no reeord remained. White whales were sporting very meoncernedly in the brisk tide whieh, ncar the Cape, flowed to the southward, but the ship evidently moved rapidly to the northward; this, probably, was merely an in-shore eddy eurrent. How the imaginations of the eroakers had conjured up the "barrier of iee," I am totally at a loss to eonceive, for here not a partiele of iee, to be seen from the land, about eighty feet above the level, could warrant an idea of obstruetion.

Passing Cape Osborne about noon, we entered on the ehord of Baring Bay, apparently but a slight indentation, and free from iee. Our attention was speeially direeted to this part of the ehamnel, fully expecting to diseover some inlet, stream, or lake, whieh might afford Mr. M'Cormiek some ehanee of discovering "a lead" into Jones's Sound, but in vain ; nor eould we find any mountain, hill, or elevation, to eorrespond with the Mount Franklin of De Haven. Before evening, all fears of barrier's had vanished, and our eoursc westerly and northerly was still elear from the mast-head.

About two A.M. on the 16th, we sloaled our water to 
thirteen fathoms off a low point of Nobody's Bay on the eharts-(there are no less thian five of these, merely bends, not bays, between Cape Hogarth and Cape Osborne); and very shortly after this, the water eontinuing to shoal gradually, a very eonspieuous eairn inland was reported. Before this I lad been reposing on my sofa, but this allowed of no further hesitation: with every power of teleseope I seamned the pile, and the more I gazed, the more mysterions still it appeared. It was too large for any ordinary eairn, and yet I thought that its regularity eould not be mistaken : at one time it appeared to be the remains of a stone loouse, the ehimney-staek alone remaining,-possibly a eolumn of masonry, and the work of man! Under sueh feelings, leaving the ship to proeeed under sail, and easting off the tow-rope, I put myself on board the 'Pioneer,' and proeeeded to solve the question, taking witl me instruments and elronometer, in order to fix its position. The 'Pioneer' grounding about a mile off shore, I landed on the beaeh elose beneath it; and it being then low water, by the shore, I well knew that she would soon float off. On reaehing this remarkable pile, I found it to be one of Nature's freaks. It was apparently the remains of a limestone eonglomerate, or dyke, the surrounding rock being tabular, slaty, magnesian limestone, of a muel firmer and eompaet nature, on which the snow or iee acted more direetly. Ilowever, the looser roeks had fallen away, leaving this pyramidal column standing; its base was twelve feet by six, height twenty feet.

A white hare notieed us, and kept performing most suspieions eireles round us, frequently presenting herself 



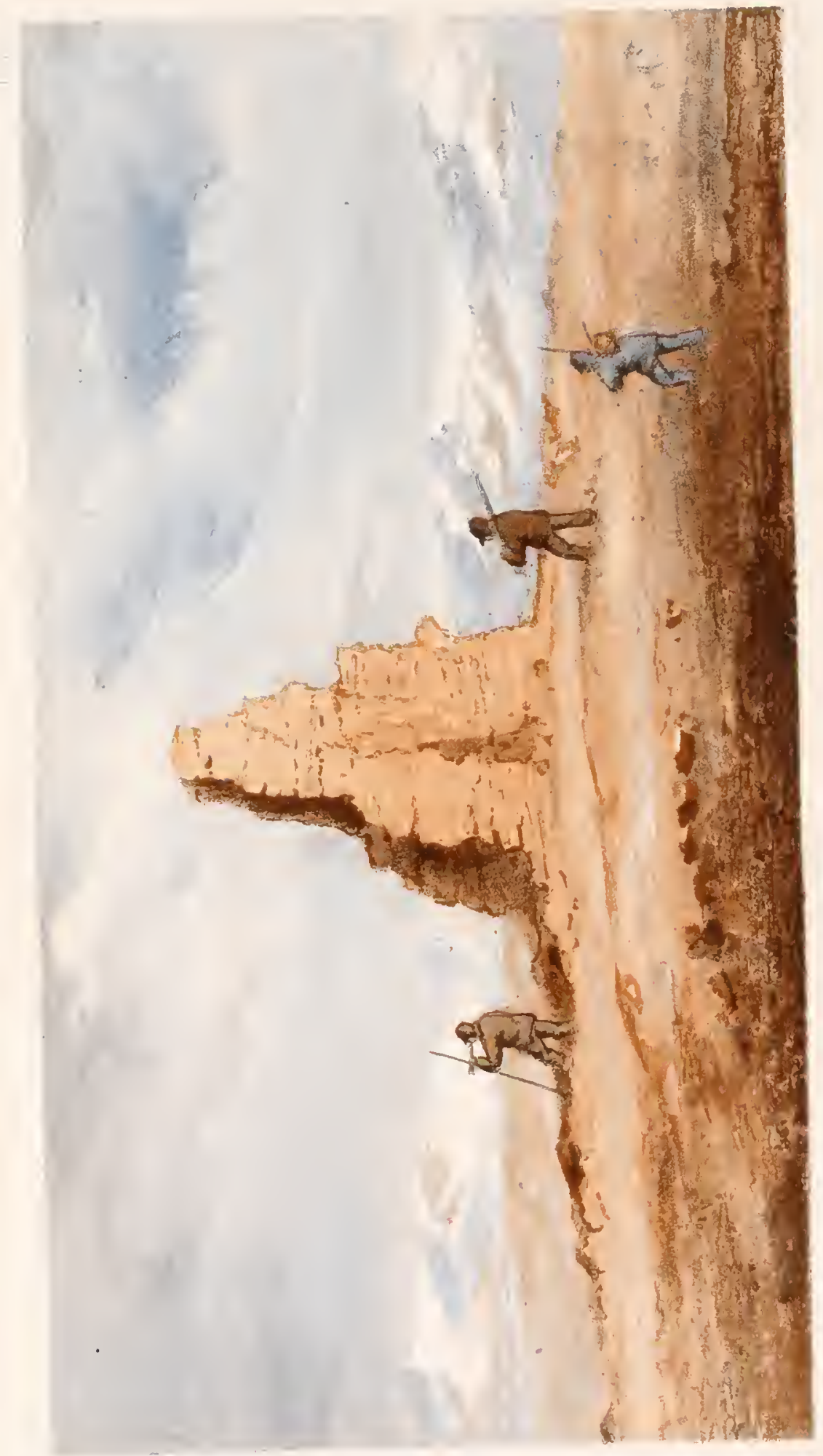


at the opposite point from which she had vanished. Dr: Lyall, who accompanied me, used every cndeavour to take her, but she never permitted him to get within range. I onee came suddenly npon her, but, not having my gun in hand, she escaped. 'The deternination of this position proved it to be the rise of Point Hogartl, and yet none of Captain Penny's travellers noticed this obelisk! It is situated in lat. $76^{\circ} 12^{\prime} 52^{\prime \prime} \mathrm{N}$., long. $92^{\circ} 4.8^{\prime} 42^{\prime \prime} \mathrm{W}$., the variation $\left.146^{\circ} 11^{\prime} 5\right]^{\prime \prime} \mathrm{W}$; a most unmistakable eminence, to whieh I have given the name of Lyall Bluff, is almost immediately adjacent. The terraced levels were strerred with bivalves, chiefly of the Mya tribe. As an example of the notices deposited at each eaim visited by any exploring officer, I beg here to add the one left at this station; they were printed forms, filled in by the officer in command of each party.

Arctic Searching Expedition, under the Command of Captain Sir Edward Belcher, C.B.

DIRECTION.

Ships.-.'Assistance;' Tender, 'Pioneer.' Wellington Channel.

'Resolnte' (H. Kellett); Tender, 'Intrepid.' Melville Island Lane.

Depót or General Rendezvons.- 'North Star,' Beechey Island.

Left Beechey Island, Saturday, 1+th August, 1852, at ten P.M.

Proceeding towards Sir Robert Inglis Bay, westerly.

Duy.-MLonday : date, Angust 16, 1852 : time, three P. м.

Condition.-All well.

Remarks. - Landed, believing the remarkable stone pillar, inland, to be a ceirn erected by human hands. Observed for latitude, longitude, and variation, and to eorrect chart.

Edward Belcher, Captain, Officer in Charge.

The day was really entitled to the appellation of lovely; 
it was serene and balmy for this climate. Having rejoined the 'Pioneer,' we overtook the ship to the eastward of Cape Majendie, and mistaking it for Cape Becher, on which I determined to land a cache, despatched Commander Richards and the master to execute this duty about elcven P.M. The cachc consisted of forty-two days' rations for ten men, or four hundred and twenty rations, and was intended to relieve our parties who might liave to travel back with despatches. About two A. M. our boats returned. The tide running strong to the eastward, prevented our getting much beyond Cape Becher before I gained the deek in the morning, so that, as we progressed, I had the full advantage of scamning the entire coast-line. To the southward, I noticed a shoal islet, not on the chart, and some very remarkable capped table mountains, in a northern deep indentation, to which I gave the name of Barrow Bay, and to the conspicuous little detached table mount, John Barrow Head; saw the islands Parker and Barrow, of Penny, and noticcd that any points he might have seen were but the outer spits of several islands covering each other and flanking the northern shore. As to the geography of the place, we were sailing over a great deal of hard land of the published charts, without injury to the "Pioneer' or ourselves! Moving on rapidly under sail and steam, I asked myself the plain question, "Would Sir Jolm Franklin, under such circumstances, stop here to erect a cairn, with the sca open before him?" I exelaimed to myself, No! and, tainted with some such prejudiee, and with such a breeze thinking it would be sinful, on we went. But there is an end to all things, 
and so, having reached the end of the far-famed Queen's Chamel on this side, and our progress impeded, I thought that some beacon should designate the turning; and further, as it had now beeome neeessary to seek for our next course, I detcrmined on ascending the mount, the base of which I have retained as Cape Sir John Franklin, from whence I obtained a most commanding view of land and iee from north to west and round to the soutl. But unfortunately, what we little drcamt of when we commenced our ascent of this mountain, was clearly exhibited to our scnses, for tcu miles beyond the basc of our position, an ominous icy barrier prevented further plogress restcrly! The only chance which seemed to offer was by taking the nortl, through the inside passage, which yet rcmained to bc examined. Bencath us lay a magnificent sound, hemmed in by two great islands, and until Nature was inclined again to favour us, there wc must await her pleasure. To this clevated position I gave the name of Mount Percy, taking possession, in due form, for Her Most Gracious Majesty Qucen Victoria; and to the sound beneath, that of Northumberland Sound, in lionour of Her Majesty's Minister, the noble Duke presiding over the Board of Admiralty.

Deseending in somewhat diminished spirits, I rejoined the 'Pioneer,' recalled the ship, which was fast dropping down into the icc, and suceeeded most happily, as things turned out, in securing her that night in safe quarters.

Numbcring our particular events, I term thc passage of the Qnecn's Channcl No. I fortunate. 'That of securing the ship before she fell into the jaws of that ice, No. 2; for most assuredly her timbers, unless she drifted back in 
the direction of the strait by which she entered, and had eontrived to reaeh Barrow's or Sir Robert Inglis's Bays, never would have repassed Beeehey Island (if they ever do, as it is). From the summit of Mount Perey, Cape Beeher is shut out, and Bailhe Hamilton Island not definable. The Point to whieh Captain Penny has given the name of Sir J. Franklin, is the point of Long Island, twelve miles southerly, eovering Barrow Bay; but as it was manifestly intended by Govermment that the names of Sir Joln and Lady Franklin should oeempy the limiting points of the Queen's Channel, I have removed them there.

From this point our new world eommenees; and as I have taken sueh liberties with Sir F. Baring Bay on my passage up, I think I eannot better plaee his name, than by giving him the great bight within us, easterly. I have not interfered with any of the points southerly, as named by Captain Pemy, but the islands will take appropriate names as niay be hereafter assigned to them.

August 18.-Our measmres were not taken an instant too soon; hardly were we seeured in Northumberland Sound, than the iee began to threaten, and it soon became evident that we must seleet more seeure quarters. IIowever, before the iee had made any breaeh into our snug position, I ran over with the 'Pioneer' to the northern remarkable island, and from its summit I soon pereeived that, for the present, all progress by ship must be stayed. I had also sent Conmander Richards to another higher mount, so that our motions, at all events, by ship, boats, or sledges, should be based on some fixed positions. The view from the pimnaele of the island, 
whieh has been temporarily termed Pioneer Island, was truly eleering. To the north and casterly, islands and land as far as the teleseope eonld see. Nothing but ice oeenpied the are of the horizon from north to westsouth-west. There lay the Aretie Ocean ; Cape Lady Franklin, at least our newly-named eape, appeared to bound the southern shore, but the loom of land was evidently visible further to the southward and westward. On my return to the ship, Commander Riehards informed me that he thought a very eomplete little harbour would admit the ship on the opposite side of the Somnd. It was foumd, however, to be unfortunately barred by a ledge of gravel, laving only twelve feet; but immediately outside and behind it Nature appeared to have thrown ont a roeky spit, whiel would afford us shelter within, and at the same time be at the hine of open water, should oeeasion require any immediate removal. Into this, as our other position was in very deep water (thirty-six fathoms), and mueh exposed, we were aeeordingly transferred, and, as events proved, not an hour too soon. From that spot the ship never moved, nor eould have been moved, for any sensible purpose that season!' Nor was it possible, had suelı been the eommand of their Lordships, to have moved any vessel westerly of that position; moreover, had sueh been praetieable, no man in his senses, having a diseretionary power vested in his hands, would disgraee his trust by any sueh mad attempt, when the special objeet eontemplated by this Expedition eould be mueh better achieved by boat or sledge travelling. 


\section{CHAP'TER IV.}

Frozen iu.-Sledge Travelling.-Walrus Shot.-Habits of the Walnus. - Village Point.-Esquimaux Hut.-Deceived by Mirage.-Tent Equipage.-The Seutinel.-Ice Accumulations.-An Intruder.Exmouth Island.-Rejoining of the Party.-Nip and Piling Ice.Quit Exmouth Island.-North Cornwall.

Trne position whieh we had taken up will be best understood from the small plan of Irorthumberland Sound, of whieh a very rapid survey was made during the progress of feeling our way, preparatory to more deeided exploration.

Our anehorage, although very nearly land-loeked, was very eapaeious, and afforded great seope for heavy masses of iee to play their pranks. But I eonsider our prineipal safeguard from any sueh visitation eonsisted in the tidal stream, whieh set direetly parallel to the ehord of the bay between our outer point of the peninsula and the opposite southem hom of the bay; and the motion of the iee from the westward would be further impeded by a long shoal islet, stretehing well out to the northward of the great island, and flanked by a smaller one within, on whieh they all appeared to expend their impetus. The outer point of the peninsula (ealled Mount Beanfort) was 

our first protection, and the ledge off the intermediate rounding angle our perfect guard.

With a rapidity not at all understood, we beeame suddenly frozen in, and at a period too when previous navigators would have led ns to believe that the ice might "break up" for the season. What impressed me with the convietion that the present oceurrence was deeisive against further motion, I eannot conceive, nor did I wait to inquire. I had seen enough to instruet me that deeision only would enable me to save the remaining part of the season, and, if properly employed, would make a great extent of the northern land, estimated as forty miles distant, British territoly.

August 20.-About midnight on the 19-20th, the 'Assistance' ceased her travels for the season. On the 23rd, at 7.30 A.M., three sledges and one boat moved out fully equipped, from the 'Assistance.' The Hamilton boat and Londesborough sledge-the Captain, and Mr. Loney, master. Sceond sledge-Commander Richards, and Mr. Grove, mate. Third sledge-Lieutenant Osborn and Dr. Lyall. The party eonsisted of twentyseven persons, and earried twenty-one days' provision.

A short space was navigable, to whiel the other boats aided us, but quitted on reaching the outer floe under three hearty cheers. At starting, the 'Hanilton' alone was available for erossing the lanes of water', but this so much retarded us tliat Commander Riehards returned for one of the whale-boats. We had then advaneed about three miles. On one occasion we enlisted the serviees of a pieee of loose iee, on which a sledge and erew eomplete were, by our united sounding-lines, warped across 
safely. But it was not a little amusing to wateh the eountenanees of some of the party ferried,-more doubt than eonfidenee prevailing. Here we eneamped mitil Commander Riehards returned, or until the following morning, during whieh time I sueeeded in shooting four walrus, two of whieh I was enabled to seeure, but, Dyak fashion, their heads only were at this time taken. During our absenee on this journey one of the beheaded eareases floated near the ship on the floe-pieee where I had left him, and was eaptured, but not, I believe, without further expenditure of ammunition: of this I have no partienlar evidenee: he had no head to speak for himself, and no sueh trophy was produeed. It is not pleasant to narrate aets which bear the impress of eruelty, and I must eonfess that, on refleetion, the killing of four of these animals, without securing them for use, was umneessary: the sportsman seldom thinks of this. The death of monkeys or parrots, and turtle, where they eould not be consumed, has often brought me to the same reflection. But without dwelling further on aets or motives, the duty of naturalist eompels me to notiee the eonduet of these warm-blooded animals on being wounded. The father, mother, and eubs were of the party. On the death of the mother, or rather on reeeiving her wound in the neek, it was painfully interesting to notiee the aetion of her young: one literally elasped her round the neek, and was apparently endeavouring to aid in staunching the blood with its month or flipper, when at a sudden convulsive pang she struek at her infant with her tusks, and repeating this several times with some severity, prevented its further repetition. The male, with a very white 



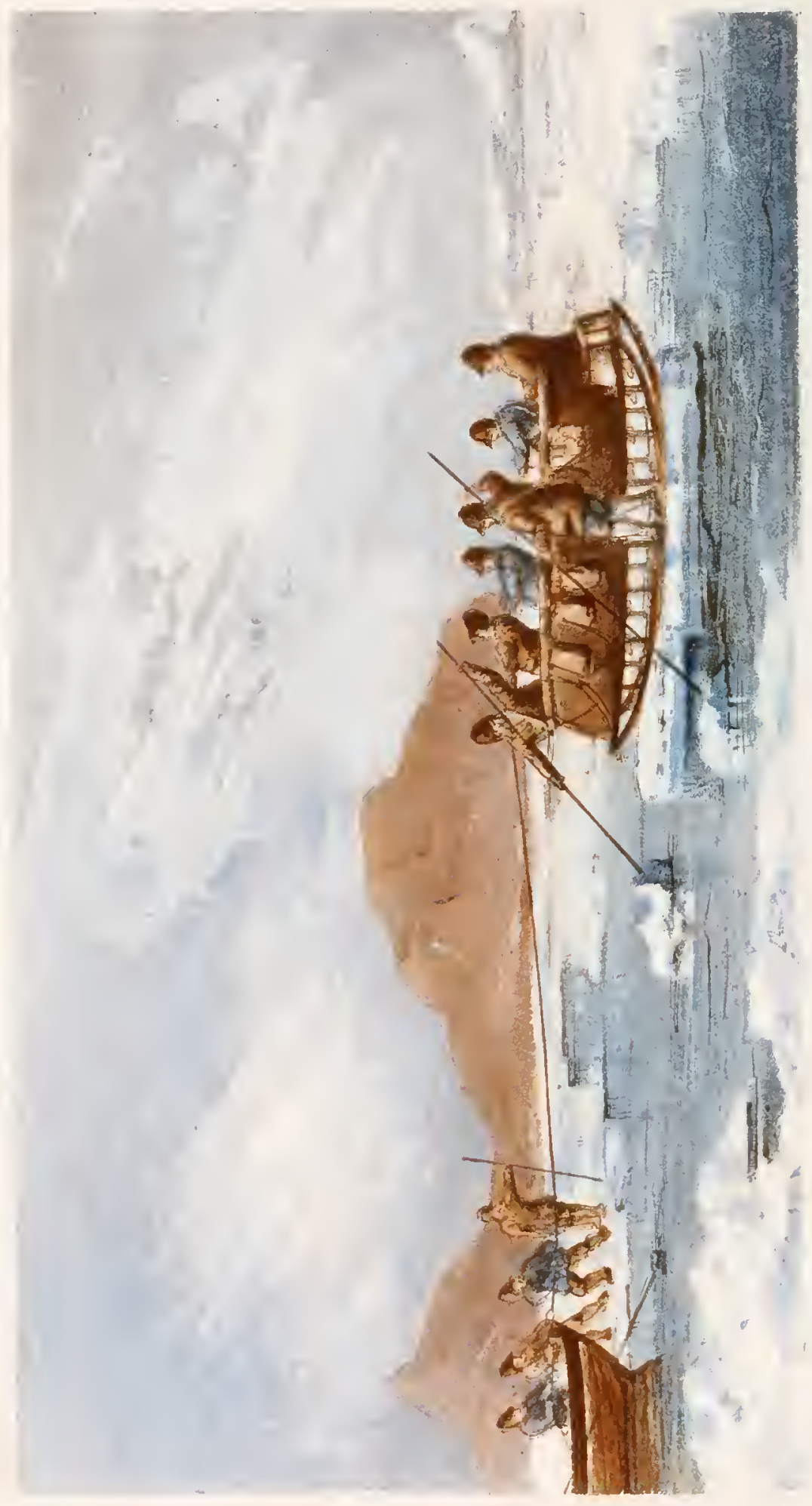


beard (strong horny bristles), came up repentedly in a most threatening attitudc, snorting aloud his vengeance; and well satisfied was I that the floc was my safeguard: doubtless he would have wreaked his vengeanee on the 'Hamilton,' and we should have met our punishment! Another, finding that she could not longer swim, deliberatcly hanled herself up on the floe to die. Now with all due deference to anatomists, who may afford us full proofs of the eapability of these animals to walk like flies on our ceilings, I must protest, from frequent observation, against the use of the flipper of the walrus for this purpose. It does not appcar to be of grcater aid than that of the seal is to that animal; and, strangely, its nails are placed on the upper side of the flipper, somc inches within its margin. That the power of exerting the vacuum exists, I doubt not. But hcre, within a few feet, deliberately did I watch the progress of the animal in effecting its purpose. In the first place, the tail and fins, cxerting their full power in the water, gave such an impetus, that it projected about one-third of the body of the animal on to the floe. It then dug its tusks with such terrific force into the ice that 1 feared for its brain, and, leech-like, hauled itself forward by the enormous muscular power of the neek, repeating the operation until it was secure. The forcc with whieh the tusks were struck into the ice appeared not only sufficient to break them, but the concussion was so heavy, that I was surprised that any brain could bear it. Can any one then be surprised, when they are informed, that they "die hard," evcn when shot throngh the brain?

As the 'Hamilton,' our' sledge-boat, will frequently 
occupy a very conspicuous position in this narrative, I may as well explain that four of these boats were supplied for light ice-travelling, built of eanvas and very thin board ecmented together, and weighing three hundred pounds. A model of a Norway boat having very kindly been lent to me by Captain Hamilton, the Seeretary of the Admiralty, these boats were a modification, improved as the four were successively in progress of building; this, being the last, I scleeted, and named her after my kind friend. She might be termed a brown. paper boat, but did her duty well with those who knew low to manage her.

As Commander Richards would have much further delay, and my operations could progress without him, I pushed on for the low point in sight, being the extreme seen from Mount Perey. Here we construeted a very large cairn, composed principally of the remains of an Esquimaux encampment, and which gained for the station the name of "Village Point," This village, or encampment, was of the most substantial construetion, and from the remains of bones, ete., not of such great antiquity as travellers in these regions are in the liabit of assigning. Great ingenuity and labour had been excrted in their eonstruction. They were not superficial, but their foundations were laid at least three feet below the ground, - a matter most diffieult to cxcente, even with our tools, at any season! These foundations were of stone, in double walls, with the interval filled in with fine clay and gravel. The doors faced to the east, and evidently had the long passages usually appertaining to those of settled habitations in Greenland. Further, as noticed at 
Cape Riley, all the stones were larger, and different from any others notieed on the Point.*

The general form of these houses was that of an oblong oval, about ten feet by twelve, having the doorway abont three feet wide by two feet six inehes in height, on the floor-level, deseending easterly to the external adit.
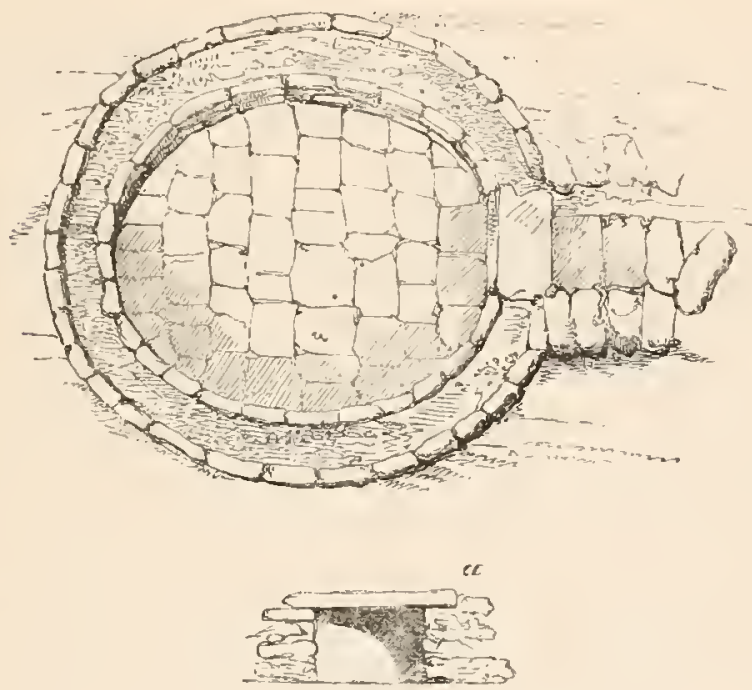

One from whieh this sketeh may be said to have been taken had the flat stone remaining over the doorway, as at $a$. When I venture the observation recent, I wish to be understood as having then, on the spot, asserted sueh to be my belief, irrespective of later diseoveries; and I felt satisfied, from general olsservation of the operations of nature during a season, on stone and other substanees, in these latitudes, that no suel long period as "hundreds

* None were seen but those of which the houses were constructed. 
of ycars" could be assigned to them. I have studied this mattcr lately with some interest. I have dug in the grave-circlcs (not fireplaces, for they do not contain a trace of fuel); have noticed the bones, as well as the moss, which latter doubtless was deposited with them; but the moss is not that of a long period,- - not hundreds, nor fiftics of years. I put the question to opponents, Why does the moss exist solely in these structures? It is nevcr seen outside these accumulations of stones, nor docs it belong to the locality, -it is marsh moss, brought from a distance. If this moss, torn up and displaced, rcmains thus in its new locality, why docs the common saxifrage, which elsewhere abounds, cease to exist near any of these spots?

But to return to the huts. These structures,-more recent, and unlike anytling noticed at Cape Riley,-indicatc more purpose, morc detcrmination to residc, and are near to the very spot where walrus, seal, duck, decr, ctc., are to be met with, and the profusion of such bones indicates this most completely. Decr we know to be in this region; they were fired at by some of our later party, and their recent tracks on the snow wcre cvident.

The "tecming of animal life," described by our predecessors at Cape Bccher, wc have not witnessed, nor have we secn anything to warrant, beyond the chances of walrus, anything worthy of being calculated on to support a party, by the cliase, on shore or afloat. Hunger, it is true, reduces the appetite to strange food; but at prescnt no attempt to substitute walrus or bear, for other food, would be relished by the majority.

At this point coal was found, both at the huts and at 
the water-line; it had been evidently washed up by the sea; also some few bits of very muel deeayed wood and a small flaying linife, made of wood, elosely resembling,

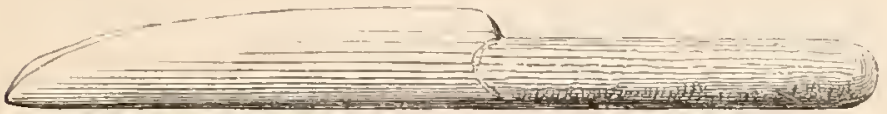

in every partieular, those of ivory found amongst the Western Esquimaux. It was earefully preserved, with other fragments of wood found on this coast-line.*

Our operations liere being eomplete, and no signs of the party yet advaneing, launehing the 'Hamilton,' we moved forward, leaving behind the neessary instruetions for their guidanee. This journey, being our first sea expedition, and testing the eapabilities of our boat, laden with all the sledge and tent equipage, in rough water, was a most eritieal as well as interesting experiment. She answered well; was light, and easily liandled. Another of the visions dependent on the state of the atmosphere, and so perplexing to Aretie travellers, bewildered us today. This was the impression of a bloekhouse, or square building, on the slope of the nortlı point of Pioneer Island. The nearer we approaelied the spot, the more we felt eonvineed that this time there was no illusion. We landed and pushed up the liill, with more auxiety than usual; and scarcely eould I eredit my senses, when I approaehed within a few yards of the objeet, to find it merely a square roek, not exeecd-

* Nothing at this point could be traced of any coal-bcaring associations, nor were any traces observable on the adjacent land. Bituminous shale was found on a low spit, seven miles to the south-west.

VOL. I. 
ing four feet on its sides, and not more than one foot above the surface of the ground. This was our house! I recollect something, in former voyages, of ptarmigan being mistaken for musk-oxen, but they were more distant and on the snow.

We now pushed forward for a long, low island, about five miles to the northward, appearing in the clistance as a mere gravel bank; but this proved to be a deception, of an opposite character. Fortunately, we were favoured hy a narrow lane of water, of which, having launched our loat, and stowed our sledge and cargo therem, we made good use, although at any moment the slightest movement of the ice might have pinched her to atoms. We renched it about four P. M., very glad to encanp for the night, and await the arrival of om party. This being a new possession, the colours were duly displayed; it was found to be at least eighty feet in height!

Our mode of cneampment, ete., not having been cxplaincd in any works published, I shall here give a rough outline of the tent, cquipment, ete. 'I'he tent is very similar to that of Amcrican hunter's, with this cxception, -instcal of two forked poles, and one horizontal, resting in the forks, with the sides pegged down, the extremities of these are framed by two boarding-pikes, forming the pitch or shecrs at cach end, and a horschair (clothes) line stretehed over these forks, and well secmed to the sledge at the back, and by a pickaxe in front, keep all steady, - so long, at least, as they hold. Tustend of pegging, the sides are well banked with snow, which retains the heat, and keeps them pretty secnre, if well performed; but if not, the brecze is sure to pene- 
trate and create more rattling than is conducive to comfort or pleasant diceams. Eaeh per'son is furnished with a blanket-bag, formed of thick drugget or felt, having an outside shell of prepared brown holland, supposed to be impcrvious to the air. The offieer, who should always occupy the post of holour, is loeated at the extreme cnd, and that end is always placed towards the wind, in order to prevent its blowing into the mouth of the tent; he is able, therefore, to feel exactly for himsclf, as well as those around them. Into this chrysalis bag, by dint of a kind of catcrpillar wriggle, each individual contraets himself, endeavouring, by every reasonable mode, to produee a suffoeating heat, and using his knapsack, boots, sextant-ease, or any othcr convenient object, for a pillow. Indced, it is absolutely necessary to placc any artiele, to bc worn on getting up, sufficiently in contact with the body to prescrve its flexibility, or to prevent it becoming frozen. Over the snow is spread an oilskin canvas and buffalo-rohe carpet; and when all are laid out, or have supped, a general coverlet of felt is superadded, whieh is supposed to eonfine the accumulation of animal warmth. Cold, it is imagined, does not ascend, nor heat descend; yet it is very distinctly felt in both ways, especially when the warmth produces something vcry similar to a thaw beneath. But the enemy,-not "the swect little cherub," etc., but the barber,--is ever aloft, condensing the breath, and dropping down refreshing snow-showers, which makes one very dubious about exposing his head outside his shcll, the lap of which he manages to turn down, and complete the envelope. 'The cookcry and other proceedings are more 
commonplaee. In these tents you sleep as soundly as you ean faney, under the temperature, unless the whispers of "bear," or the ominous snuffling of that animal, should induec you to ask, "Who is cook?" As this personage, although permitted to sleep at his post, is the sentinel par cacellence, he of eourse has the place next the door, and, if not very somd asleep, is aroused, and betakes himself to rceonnoitre; the result may appear in another aet.

In the morning we aseended om hill, eighty feet above the sea, to look for our party, and to eonstruet one of those eains so emphatieally reeommended in my instrnetions. These struetures arc supposed to be of stone; but as the ground here was fine gravel, and frozen hard, enough eould not be amassed to smpport our flagstaff. Neeessity, however, effeets wonders - at least for temporary purposes; failing in stones and gravel, we lad reeourse to a penty moss, found in a kind of morass at the back of the summit. The foundation having eommeneed with this, the men soon found that the peat mud was warmer than the air, and froze as they used it. Sailors have their ideas of cnjoyment; and as this proved a novelty, a new mode of building was immediately adopted, and between peat, with blaek mud for eement, aided by a sharp frost, a very fine black pyramid arose, quite as solid, so long as frost eontimued, as any eonstrueted of stone. It was strange, however, that the pond of blaek mud did not freeze nor lose its tempcrature during the period we remained at work; our men scemed to enjoy the warm mud, washing their hands in it beforc retiring, and I have little doubt that, with the 
second application of water at the sea-beach, it removed mueh grease.

At this island we had a very fair opportunity of witnessing the effect of "piling ice," particularly as noticed on all westcru projections in the Queen's Chanuel, or beyond, where they are apparently exposed to the whole inpetns of the fides of the Arctie Ocean. In this instance the ice had been raised, slab over slab, on the north-west point, above the summit level of the island; and at first I was so impressed that it was one solid mass, or that it could not be an accumulation of floepieces, that I sent the master to dctermine the fact, as I suspected it to be part of a berg. But it was simply piled ice, frozen into a mass, and nearly a humdred feet in height. No bergs are supposed to be secu in these seas (?). This island had been the resort of geese and cider-cluck in the spring, many of their nests remaining quite distinet, and partially clothed with down. Shortly after our arrival, we were joined by Commander Richards, who had brought the whalc-boat; but as I wished the fact determined, as to our depôt ordered to be placed at a point on the coast, I sent his division in-shore with instructions to rejoin me at the Great Red Island (Exmonth), then in advance about ten miles.

About eight A.3. On the 26th, we struck our tents, and moved forward, aided by a short lane of water. 'The day was beautiful, and, with a temperature of $29^{\circ}$, proved too warm for travelling on the floe, which we experienced when we conmenced with the 'IJamilton' narle fast behind our sledge, Mrr. Loney and myself aiding, by helping the boat by the stern orer the inequalities. 
Method is my invariable rule, even for the most trivial duty. So far I am an advocate for the soldier's' system, or rather what I always look forward to in our profession -the establishment of a distinct corps of Royal Naval Engineers in essenee, although that term would now entail eonfusion, such being applied to the steam department.

"Knowledge is power," and sueh power enables every one conducting service of a laborious character to accomplish it with the nicans at command with less difficulty. The exertion of undue labour at one period of the day, and relaxation at another, when difference of temperature causes very important elıanges of eapability, is to be regulated, and strength husbanded. In order, therefore, to determine our actual ratc of travelling, I determined to pace our "spells," or time employed between breathing or resting places. I had noticed that the duration of a "spell" was subject to the will or eapricc of the men, or any one indolent man, if such should be present; and I found it to be an cvil requiring remedy.

Having determined, during our times of rest, that iny step was equal to $2 \cdot 33$, or $4 \cdot 66$ feet for double paces, I soon arrived, after three lours and forty-six minutes' actual travelling, and pacing 43,620 feet, at the result, that our legitimate scale did not, including the boat in tow, morc than avcrage 1.9 miles per hour, exclusive of stoppages; and these I found took the range of spells or time travelling, commeneing in the morning at thirtythree to twenty-three minutes beforc noon, and twentyeight to thirteen minutes after noon; their strength, to my most perfect conviction, diminishing between four 
and six P.x., or inmediatcly after the afternoon's grog, which was consequently discontinued until the proper time, of supper.

About 5.45 we pitched our tent for the night upon the smooth part of the floe; but just as our pcmmican was properly sensoned and ready for distribution, a visitor, not victualled, madc his appearance, attracted doubtless by the savoury perfume; this was a polar bear. Our party withdrew into the tent, and the gentleman very deliberately walked up within short pistolshot, snuffing the air with the peculiar habit of these animals, and contemplating, no doubt, a comfortable meal. A ball through his fore-arm caused him to stagger and attempt escapc; but the next, through the heart, from the other barrel, laid him low. Pemmican was entirely forgotten until his skin was deposited beside the tont, our herocs declaring "that they never could get liis jacket off, if he once got cold." Poor fellow! his confidence deserved a better return; but his jacket, as well as his fat (for fuel), were now important considerations. Our supper finished, and gum reloaded and plaeed ready for further service, wc withdrew into onl shells, and were soon enjoying comfortable dreams, far, rery far, from polar bears; but about midnight, his anxious lady seeking him, in all probability, tracked him up to the tent, and therc found his head, outer garment, and his slippers, the latter intended for a carriage comfort for a fair friend. Hcr hard breathing awakened the cook, who, as I before stated, is, in addition to " the little cherub," etc., our only guardian angcl, and who whispered along the bag-moutlis, "Another bear, Sir." 
The heavy blanket ovcrlying me, and the difficulty resulting from the general move of my bedfellows to extricate themselves, prevented my reaching my post, perhaps, as deliberately as etiquette might demand; but I found my gun in hand, and the cnemy in front, quite in time for action. The clear light which prevailed enabled me to see the eyes and black-tipped nose within about thrce yards of the muzzle of the piece, and one ball in the mouth and through the head was, I thought, quitc enough to expend; and believing it impossiblc for the victim to escape, I did not fire the second. She moved away, sponting blood, and doubtless died. Some of our people tracked her for a short distance, but were soon recalled; we had ahready morc than we could convenicutly carry, although bear's-grease is with us quite as important as to onr friends at home. After flincling this from the skin, the latter became a very useful pad betwecn our ribs and the icc.

About eight we recommenced our journey, determined to use every effort to reach our red-tinted island before encamping tonight. A similar set of expcriments on marching, with a little more attention to the periods of rest, afforded two miles* per hour with less fatigue. By two we arived at the floe-edge, and found open water leading up to the island. Launching the 'Hamilton,' we effected our landing under oars alone, in less than two hours.

August 27.-.This island, viewed at a distance of fiftwen miles, presented, from its slopes being composed of red sandstone, a very cleering aspect, and was at first

\footnotetext{
* All distances reckoner in this narrative are geographic miles.
} 



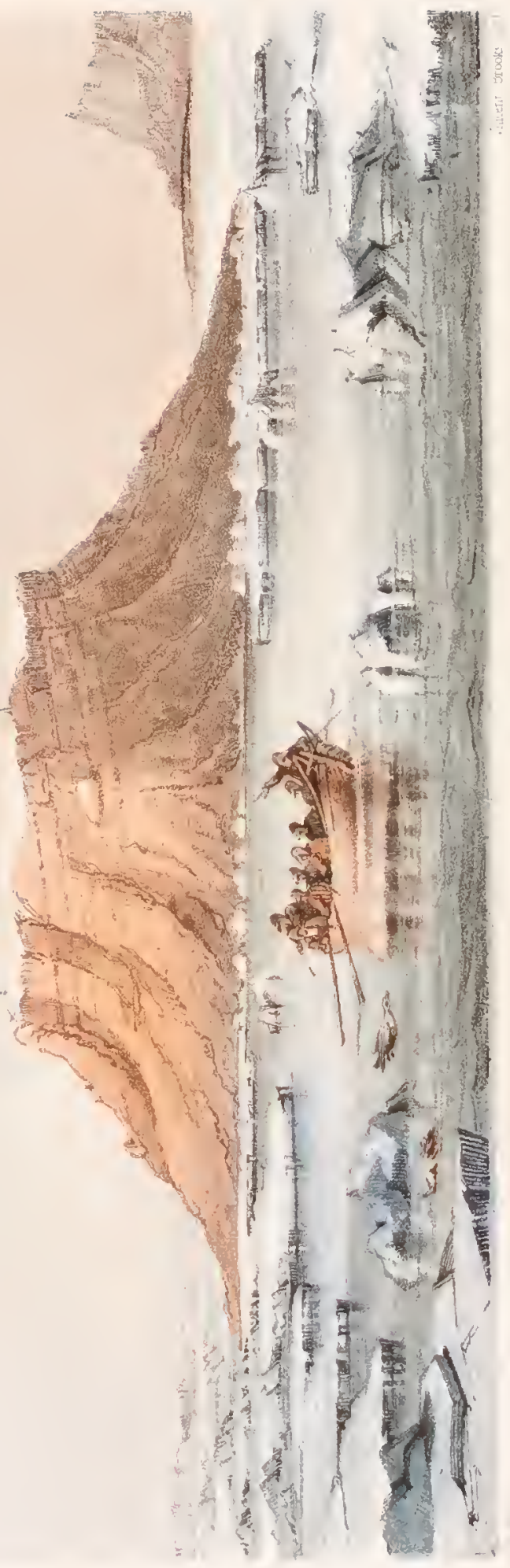


simply named Red Island; but this being the anniversary of Lord Exwlouth's action at Algicis, I took posscssion, witl the customary forms, under the titlc of Exmouth Island, which our observations place in lat. $77^{\circ} 15^{\prime} \mathrm{N}$., long. $95^{\circ} 50^{\prime} \mathrm{W}$.

The western peak I had before selected from Pioneer Island as nyy principal station, and from this commanding height I lad long anticipated a magnificent view of any lands which might fringe the distant loorizon. Such werc my calculations when I wcht to rest; the morning of the 2Stl was bright and checring, and, buoyed by hope, gladly did I avail myself of the sun for the requisite observations for sccuring my position; but in these latitudes timc, in evcry sense, is precious. Trusting to prescut appearances, I did not ascend the mount until afternoon; and just as I gained the summit, and not withont considerable labour, fog-the result of our finc forenoon-enveloped us, cutting off all objects beyond threc miles. We constructed two cairns, and continued to wander about the summit, and watelı most anxiously until cight at night, for some glimpsc; but snow-drift incrcasing, and temperature falling to $22^{\circ}$, we returned to the beacl disappointed.

The bay ice ras forming fast, the tide of ebb rumning strong to the cast, past this island, and towards a ncw channel or sea, to which, as yet, we had not traced land; it was simply a continuation of Jones' Sound, in imagination. The flood set duc west; both tides liad a velocity, taking the masses of ice carried to windward as a criterion, of two knots.

Recent marks of deer were noticed, both on the sum- 
mit and on the slopes, particularly in the now frozen watercourses, which herc form numerous radii from the mountain, and where antlcrs and skulls were frequently found imbedded in the loose sand. Geese, ducks, ptarmigan, and hares must have prevailed in great numbers; but we only noticed about twenty brent-gcese, which alighted near us, and were too wary to afford us a meal. The formation is red sandstonc, capped about twenty feet on the summit by fossilifcrous limestone, in which some large bivalves (pectens, ete.) and somc bones were found, unfortminately broken before they were brought to me. Bencath this limestone, the rock is swinestone to about threc-quarters from the base, the entirc height being 567 fect. In the sandy bed of one of the large gullies a large ball of iron pyrites was found, at first mistaken by one of ny crew for a six-pound shot, and brought to me as bclonging to one of the missing ships. Somc very slight traces of eoal were noticed at the wash of the sen, but none in situ on the island. No marks of natives were noticed, notwithstanding all these signs of ganc abounding at some seasons. Vegctation, on the great belt of this island, appeared to be more luxuriant than we have elsewhere witncssed in this region.

August 29.-This being Sunday, I had made up my mind to remain at all events for the day, and eventually cven until the rejoining of the abscntees. Our scouts soon reported the boats in sight, and before noon, fog still prevailing, Commander Richards and his party rejoined. 'They liad encamped, the night previous, on a low island near us, but it was so bcset with gromnded and piled iee that even the island had entirely escaped our 
notiee! Riehards had taken possession, appointing himself "Governor," and the others to varions plaees of trust, - an aet long remembered as a joke. Some teru were notieed, and a young one just born found on the nest: pretty temperature for rearing it, $22^{\circ}, 10^{\circ}$ below freezing !

The intelligenee brought by Riehards damped me a little, and eaused me to alter my disposition of the serviee. 'Pioneer's' boat, detaehed to examine the depôt, had met with an aecident, by whieh the men got wet and the bread damaged, besides injuring more or less all the dry provision. 'I'his eompelled me to trust to my own resourees, and alter the entire arrangement of the Expedition. I therefore gave Riehards the direetion of the partieular serviee of exploring the next ('lable Island), and of earrying up the eoast-line now diseovered to Village Point. To myself I allotted the examination of the terra incognita of whieh I had a glimpse from Pioneer Island, estimated in my own mind (but, I very firmly believe, in nubibus, amongst others) at eighteen or .twenty miles beyond our present position. Fourteen days' provision for ourselves was deposited here en cache (with the pars of the bear), and my party were all in high spirits, with "Pet Hamilton" as our trusty friend.

Richards had already found it laborious work dragging the boat and sledge by relays, and eould not therefore eare mueh about advance, unless he replaeed $\mathrm{Mr}$. Loney. But Riehards was the only qualified person to eommand, and to perform the duty required, being a surveyor. The separation was painful and inconvenient, but the separate eommand eould only eonfer additional importanee. Another consideration also aetuated my de- 
cision. I should leave behind me one of my own officers, who knew my intentions and habits thoroughly, competent to carry out the service, slould accident cut me off, and who would advance, or eome himself with, the necessary supplies, or aid, in the event of my absence being prolonged beyond a reasonable period.

Shortly after noon he parted for the eastward, in the full hope of achieving something new. I reaseended the unfortunate mountain with the same ill-suceess, but before starting directed the tent to be struck, and the bivouac slifted to the opposite side of the island. $\mathrm{My}$ readers will, I fear, charge me with presumption, but possibly I may pay the penalty before the cruise terminates. But our business is to view all obstacles as to be overcomc: " nothing risk, nothing gain."

During my detention on this southern and western point, I happened to stray with my gum to the beach, and whilst there heard the peculiar groaning of pressure, or" "nip." At first I was unable to distinguish from whence the eause proceeded, but in a few minutes, after watching the dreary white sheet until vision becane very imperfect, I noticed, first, an arching of the floe (prevailing here fiom three to four feet in thickness), then its disruption, and the flakes of ice piling one above mother in slabs, until they became influenced by some greater obstruction near the land. Then a very different action ensued. Instead of the great slabs of ice, the opposing and myielding forces, being nearly equal, caused a comminution, and the powdered substance, resembling white sugar in appearance, tumbled down most gracefully over the before-aceummlated slabs, involving all in one 
smooth detritus, which (cventually filled in with snow, and freezing into a mass) puzzles us so much, and induces us, without verification, to suspect the masses to be "bcros." But this is but a trivial illustration of the "ice motion" in, and to the northward of, the "Qucen's Channel." It is fearful to think of the possibitity of Franklin's ships entering this region, "to be driven by the pack;" no hope of escape could be entertained: and thereforc most sincercly do I wish they camnot have passed 110 ; for as to traces, none could cxist, subject to such accumulated dangers as are hourly apparent. But this is morc peculiarly forced upon my mind by the events of today. From the summit we noticed the breaking-up of a very great extcnt of floe, immediately in our neighbourhood: nothing but a diagram can sufficicntly illustrate it.

Let the rcader imagine the white shcet spread beneath him, suddenly to exhibit the deep bhe sea in the cracks,

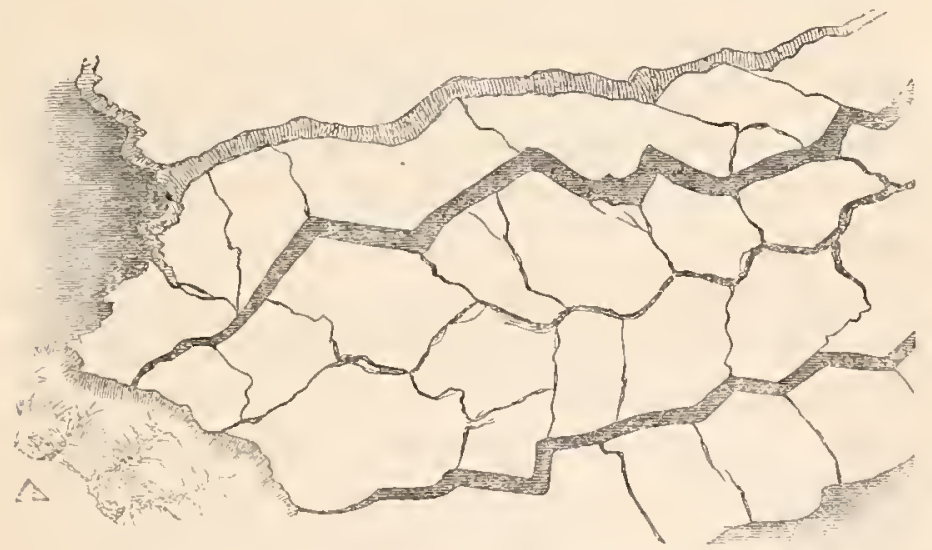

and then to notice this immense surface, some hundred acres, pcrhaps loosened by no apparent causc, from late- 
ral pressure, fall asmonder, float off, and disperse, forming in the spaec of an hour a dense "paek." Where, then, is the sceurity of doeking? It would prove endless labour to doek, unless our missing navigators should in the present instanee happen to be to the north of this great opening, when they might push sone twenty miles westerly,-but never again, I fear, in these high latitudes, to reeover easting!

About nine r.Mr., having utterly failed in gaining even enough to guide me in the direetion of "the wished-for" haven," and having the only eonsolation, that as far as I eould see in the direetion where I knew it must be, open water prevailed to a limited distanee, I quitted the mountain, perfeetly eonfident however of suceess, or that we should reael it by water.

August 30.--'Three days had now elapsed, and yet all in mist; the weather had slightly improved, and the sea was apparently open in our intended eourse: the wind also was favourable for the blindfold expedition. We paeked, and started under eanvas, the tent-poles serving as sheers or mast, and the tent-bottom as sail, furnishing ns eompletely in the most approved rig of the Malay pirate pralu.

At a quarter past eight we left the shore, and proeeeded at a very eheering rate, steering by the sun; but the breeze failing shortly after noon, we had reeourse to paddles. About one, we made ont terra firma; but as my western objeet was elearly defined from Pioneer Peak, and I felt great eonfidenee in "first sight," I pushed on for it, well aware that a latitude alone, obtained there, would seeure its position beyond dispute. About a 
quarter past two P.м. we effected a landing within the floe-cdge, and about five miles from the north-western and extreme Point of this land.

Of this new territory I now took possession for our Gracious Qucen, with the eustomary form,-ealling it, in eompliment to His Royal Highness the Heir Apparent, "North Cormwall." Sir Edward Parry having adopted the western eomties, Somerset, Devon, ete., the Scilly Isles, when diseovered, remain for some more fortunate explorer. I know not whether "Duke of Aretie Cornwall" may be added, but we drank the liealth of His Royal Highness most sineerely, to that title.

'l'hiek weather sueeeded, but knowing low fiekle Dame Nature is in these regions, I determined not to be eaught napping. Proeeding inland, to the nearest aeeessible height which would eommand a northern as well as western range, we advaneed about three miles. 'The view obtained was not indeed satisfaetory, but we perhaps were too greedy. I saw enough to satisfy me that our present position was insular, and that no northern or western land was near. I have deemed the distanee three miles, to be within bounds; but looking to the angles obtained from Pioneer Peak, I eould not be less than five miles from the westem point of the island, and our elevation not less than eight hundred feet. The ravines are deeply ehannelled out of a very friable sandstone, in the bottoms of which I noticed large masses of elay ironstone, septaria, and nodules of iron pyrites. Coal was also found, but disseminated, and impossible to traee in situ. Bivalves, apparently of recent origin, and having the eartilage hinge perfeet, were abundant. 
This is mattcr of grave consideration. When, or did the sea ever invade these heights? Yct the cartilaginous hinge was perfect, and the epidermis in many instances scarcely removed. Birds may have placed these shells; but with our knowledge of this climate, prevailing ice, and the scarcity of animal life especially, this is scarcely credible. I cannot, will not, at present say more. This friable sandstonc and sand, interspersed on the surface with boulders of granite, and almost garnet masses, constitutes the principal features of the land on the west of North Cornwall. 


\section{CHAPTER V.}

Retreat.-Land's End of North Cornwall-_Pell Point.-Table Island. - Chased by a Walrus.- Sledge breaks in.-Danger from the Ice.Observatory erected.-Second Antumual Expedition.-Traces of Gold.-Gale and Disruption of Ice.-Ooniak constructed.- Walrus food.-The 'Eider-duck.'-Gain the Land-icc.-Reach Point Repose.-Return to the Ship.

Aвотт eight P.M. it commenced snowing heavily, and not feeling very eertain about our road baek, we beat our retreat for the beaeh, seleeting the apparently best ravine. We followed it up, and fortunately came out about five liundred yards nortli of the tent. On the floe edge we notieed one very large seal, and on the land a track of fox, but of no other animal, nor any traees of Esquimaux. We estimated the north-western point of the island from our elevated position to be five miles, equidistant from us and the tent.

August 31.-On the morning of this last day of $\mathrm{Au}-$ gust we experieneed thiek moist snow, temperature $30^{\circ}$, with the sum shining at intervals between the falls of snow and passing elouds, tantalizing us eonsiderably, partieularly near noon. Fortunately I sueeeded in obtaming the latitude and true bearing of our stations on VOL. I. 
Exmouth and Table Islands, bnt no objects beyond these —also sccurcd last evening. The result places our obscrving position in latitude $77^{\circ} 34^{\prime} \mathrm{N}$., and by the true bcaring of Exmouth Island in longitude $96^{\circ} 20^{\prime} \mathrm{IV}$., exactly coinciding with the tangent obtained from Pionecr Peak, and infinitely preferable to any chronometer longitude. The west extreme therefore will be in latitude $77^{\circ} 39^{\prime} \mathrm{N}$., and longitude $96^{\circ} 15^{\prime} \mathrm{W}$., and the Land's End of North Cornwall, the nortl-western extreme of the island, scen from the hill, probably in $77^{\circ} 45^{\prime} \mathrm{N}$, and then trending about N. $30^{\circ} \mathrm{E}$.

September 1.-Our insidions enemy, the floe, had played us a trick, hemmed us in, and left no eseape by water. But, supported by the pieked men of the 'Assistance,' no trifling difficulties could stop ns. We therefore, after a somewhat heavy tug over the land, with the boat also to transport, regained the open water, launched, and werc again on our clement. Jaek Frost we were civil to; he was our insidious encmy, at least in the present degree. In all his vigour we laughed at him, as then we should have solid icc, but so long as he maintained the Christian symbol $(+)$ le was to be dreaded.

Here we have reached the exciting 1 st of September; and yet, although these regions have been portrayed as tceming with animal life, I mueh doubt if even the sharpest Esquimaux would find anything wortly to present to his lovely wife and danghters on this evening; cren bears and foxes scem to be forgotten, or probably have not volunteered for this service. After we quitted the shore, some few timid seals put their inquisitive licads above water, as if to inquire the cansc of 
our visit, but were soon satisfied. Indeed the aspect of nature throughout presented that heavy gloom which shonld accompany this very type of barren solitude. Pulling along the coast for a pcriod of six hours, and cstimating the distanee traversed to be about seventeen miles, we reached the sonthern angle of the island, where the first high jutting heads frown upon the eoastline, which, in the interval from ou late station, presented but a suecession of low spits and creeks, probably intersecting this part of the island; and at one opening, about five miles from the western station, a narrow strait appeared to divide that portion into a separate island.

Under a pair of high "double eliffs" we pitehed our" tent; the snow was deep for the season, and no vegetation to be traeed. At sunrise on the 2nd of September, cvery prospeet of a bright, clear day promised, and I suceeded in obtaining the sun, as well as angles to Exmouth and Table Islands, but the snow still continued to fall, baffling further exertions. I ascended the ligh land commanding the eastern horizon, which at that time was very elear, but no land eould be traeed easterly of Table Island. The eastern limit of North Coruwall I was enabled to trace about fifteen miles, where it seemed to terminate in a low spit, and then turn abruptly to the north.

I have therefore but little doubt that this great eastern space comnects with Jones and Snith Sounds, or the Polar Oeean, on whieh the seareh of the next season will doubtless throw more light. Our business, it is true, does not so much concern gcographieal diseovery, as the 
most serutinizing seareh, not only for vessels, but for persons or theil traees; and, however eonfident our opinions wnay be that they could not exist for such a lengthened period in this vieinity, still no exense wonld be satisfaetory, if we failed to silenee the conjectures of those who might even imagine that any reasonable spot, to which aeeess to them would perhaps be impossible, had not been rigorously examined. That duty yet remains to be exeeuted, God willing; and in the proseeution of that duty, it may yet be our lot to determine if Sir Jolm left any reeord in the so-ealled "Jones Sound." It is far from inpossible that his vessels may lave entered this region, and have drifted even thus far. If they reached this open water by Jones or Smith Channels, my impression is that they wonld endeavour to gain the northern water, and may be anywhere within the parallel of $50^{\circ}$, but I doubt it exeeedingly. The latitude of this position was determined to be in $77^{\circ} 29^{\prime} \mathrm{N}$, longitude $95^{\circ} \mathrm{W}$., variation $141^{\circ} 1 \mathrm{~s}^{\prime} \mathrm{W}$. It received the name of Pell Point.

In this region, where the tides or eurents are seareely obstrueted by islands, and run with some veloeity, ripping up the floe like paper, mueh open water must of neeessity prevail, and possibly still more so to the northward. 'This may offer' the means of drift to and fro, but not the means of mavigation; nor do these islands afford either sustenanee, elianee of harbour, or refuge. That they are not washed by any free emrents from Asia or Ameriea, the total absenee of even a partiele of drift would seem to infer. 'The young iee threatened to annoy us; and a stretelı of seventeen miles, under sueh 
eiremintanees, was not eertainly without risk; but who knows of any other work here-even in our brown-paper boat! Our safer course was, no doubt, by the floe; but 110 floe was at hand to aid us. Cutting the matter very short, we launched, toiled hard, experienced a nasty, toppling sea, but eventually got up to Table Island, fetehing about ten miles to lecward of our intended port. Nevertheless we were grateful to reaeh the shore, and made the most of it; but heavy "paneake iee" intervened between us and our haven. I required but one glanee of the eye from our iee-mate, Bond,--never behind in eourage at this work: I knew that he did not object. In we went, and, by dint of labour, spooning, rolling, and eventually getting a line to the ice agronnd, slept on shore that night! Very muel delighted indeed were all of us, and if the 'Hamilton' could blush-but she was painted yellow-she must have felt very uneasy at her praises, so very broadly expressed. One Irishman deelared that he would either buy her, or have just such another built, and make his fortune on some lake in Ireland. "Well done, little Hamilton!" often burst from my lips; and many a good eruise yet do I expect her to bear me through, before she be laid up in Greenwieh. Here we are then, nolens volens, east ashore on Table Island. 'This particular spot attracted my attention from the summit of Exmouth Island, and I had instrueted Commander Richards to examine it, and place marks. I fully expected to be able to haul our boat over into a magnificent harbour, formed by the low land encireling nearly the western head; lut the neck, which at ten miles appeared but a thread, was now found to be 
nearly a mile, and the whole interior of the harbour onc sheet of ice. To this harbour I gave the name of Londesborough, and to its point Grimston.

September 3.-During the night the current had fortunately swept away the ice from our harbour, and left us free to pursue our journey. The morning was fine, beautifully clear, and the sea westerly open to Exmouth Island. Ascending one of the commanding hills, I obtained a view of the leading features of this island, as well as a station in connection with some of those erceted by Captain Richards. The breeze favouring, about eight A.M. we put to sea, and succeeded in reaching Exmouth Island shortly after noon; lumehed, took up our cache of provision, and, as the wind continued favourable, lost no further time. Winter was now approaching most unmistakably in earnest, and a few hours might render our work either very laborious or very simple. The ehange which a few days had made here was impressive; I could liardly recognize the features of our late encampment, and the beach was only by dint of great labour accessible. The main floe was in motion, and continned to press easterly; but the breeze increasing with heavy snow, and the tide setting strong to windward (westcrly), and driving heavy pieces of ice end on to the floe, foreing the boat also so strongly on it as to damage her, rendered decision neeessary. I therefore quitted the floe and made sail, but right glad were we to seek shelter" for the night on "Governor Richards' Island." Chased, I believe, by the identical old walrus before alluded to at the commencement of our trip, we felt very quecr, and as he muttered some unintelligible warnings, we were cxcessively eivil. 



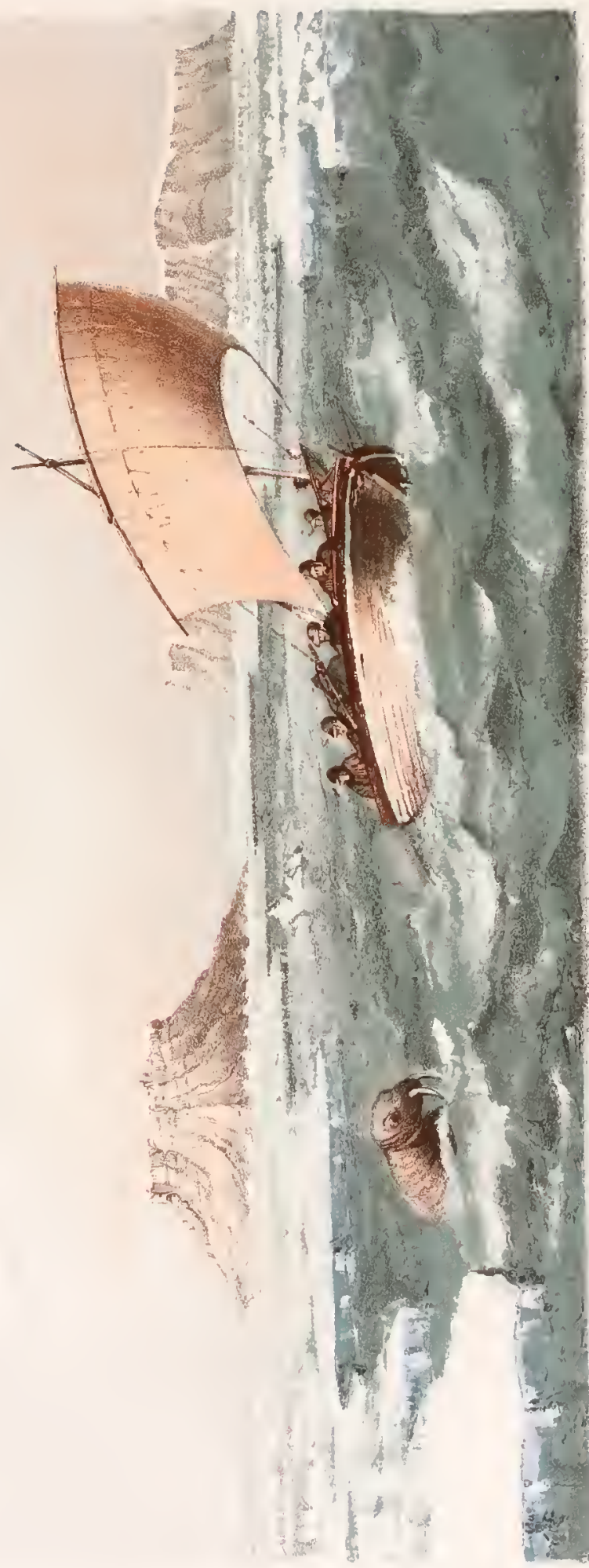

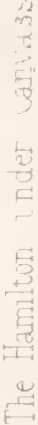


Wc were fortminte in reaching this island: the sea was getting troublesonic, the boat refused to steer by the oar, and she was fast filling; one dash of spray, and our castles would be demolished; any impudent wave might have given us a wetting which would have rendered that night eomfortless. Every such incident as that beforc my eyes forcibly brings to my mind the utter helplessness of any of our mfortunate missing friends. One wetting, without the means which we possessed of drying themselves, would have destroyed their cnergies.

On the morning of the 4 th September, the wind having lulled, we launched our boat, and pushed forward to avail ourselves of the yct open water. About noon we succeded in effecting our discmbarkation on the floc, and, after luneheon, recommenecd floe-travelling. Shortly after we diseovered the other party in-shorc of us, under the land. At one of our halting-places, Commander Richards and Dr. Lyall came up with us, and having sparcd them part of our provisions, we resumed our progress, fully expecting that they would overtakc us at our resting-place, for which object we shortened our mareh. 'They evidently made heavier' work, and pitched one mile short of us.

September 5.-Haring nothing further to detain us, we made the best of our way to Village Point, expecting to reach it this night; but the half-frozen lanes, breaking repeatedly, considerably retarded us; latterly however I contrived, on some oceasions where it was very narrow, to bridge the passage by floating pieces of ice cast into the gap, and by a dexterous rmo over our floating bridge, got safely aeross before it became immersed. Owing to 
sueh delays, we were eompelled to eneamp at evening, still distant from Village Point.

On the 6th we experieneed a fine, sumny, lovely day, and pushed forward at 8.30 ; but, still retarded by the diffieulties before alluded to, it was not until 8.30 P.M. that our advaneed party, with the boat alone, reaehed the point. Having pitehed the tent, a party was sent baek to bring up the sledge. Unfortunately they had no offieer to lead then,,-got on to young iee,-broke in, and very nearly lost one of the erew; providentially it did not prove fatal to all, as, from their aeeount of the matter, they aeted very injudieiously, by simultaneously rushing to the edge of the broken iee, to save their shipmate, instead of forming a comneeted ehain to more solic iee. I almost instantly deteeted this misfortune, by noticing a single man on the outline of the snow, wringing his hands and throwing off his boots. Mr. Loney and others were despatehed in aid, but notieing the remainder of the party showed their heads, I detained the eook, to prepare liot tea, ete., which the man who had been immersed very mueh needed,-reaehing the tent, assisted by two others, in a very exhausted state. He was soon elad in dry elothes, a dose of hot tea and spirits administered, and paeked in lis bag; and by the time he got warm, a pint of hot eloeolate and pemmiean were ready, to eomplete lim for his slumbers.

September 7.- The morning fine, but temperature $18.5^{\circ}$. Moved up to the erest of the peninsula, erossing recent traeks of bears, foxes, and deer; the latter either very numerous, or a pair had been making very extensive gambols, tearing up the grass, ete. 
Commander Richards was noticed making good progress down a lane which had opened, and, by the time we werc about to quit the Point, landed to receive his final orders. We then moved on to Pioneer Island, to complete our work, and thence to the ship; but experienced very difficult work in crossing the young icc, which threatened several times to press the boat by a shear-like novcment, one sheet overlapping the other, but she escaped with one holc only in her bows, which I succeeded in stopping with my silk handkerchief. Unfortumatcly we did not reach the ship this night, but cncamped on the floe, and fired a rocket almost over their heads, to warn them of our being near': this, however, was not seen.

In the morning we pushed forward, and soon joined, or came upon the track of, the other party, which, by not having any off-shore duty to excente, had avoided our difficulties. On opening Momnt Bcaufort, we noticed parties from the ship advancing to aid our men; but I believe that in the succeding two hours, until we reached the ship, morc damage and wettings were experienced than during our whole cruise. This resulted from the icc being much weaker in this direct line of greatcst tidal force: it is the last portion frozen, and the earliest thawed. About 4.30 I re-entered my cabin, quitc prepared to enjoy every comfort it might offcr.

Winter Operations.- The winter had now been completely established, and the 'Assistance' and tender firmly frozen in. The customary preparations were made for housing in the ships; but as we considercd the vessels too secure to require any extraordinary preparations, the 
topgallantmasts were merely housed, and sails seeurely furled.

The absurd fittings of the Sylvester warming-apparatus, requining the main hold to be nearly elcared before the fires eould be lighted, eompelled us to plaee the provisions, ete. on shore, as well as the greater part of our sails, boats, hawsers, ete. In all this I of eourse aequieseed, beeanse it was the routine of my predecessor's; but I must say that, for many reasons, I doubted the propriety. In the ease of provision especially, I do not think that salt meat, subjeeted to exeessively low temperature, is improved, but, on the eontrary, vitiated; first, by the freezing proeess rupturing every vessel whieh before resisted the piekle; and, seeondly, when thaw takes place, permitting that same piekle to take greater effeet on the meat. It is very mear akin to euring meat or Burnetizing timber by exhaustion.

'I'he Magnetie Obscrvatory, eonstrueted from piees of wreek saved in Melville Bay, I found well advaneed, and near to it, beyond any possible influenee of the iron employed, at a distanee of twenty yards, one of the cutters was inverted, on supports, to afford a thermometer house. In this it was purposed to submit all the thermometers supplied, to dircet exposure on $180^{\circ}$, or lialf the eirele, faeing the soutl (true). The Observatory was also fitted for two transits, whieh could be brought to aet together, independently, or on eertain stars at fixed altitudes. This was eventually given up, and the instruments removed; first, on aecount of the eold affeeting the clamps, but prineipally from the breakage of two levels by meddlers, and, finally, some influenee whieh I 
faneied their steel fittings might have on the more important movements of the magnetometer.

The walrus, before mentioned at our departure on the north-east journey, floated or was driven by the paek near the ship, and its earease secured by our sportsmen for the dogs. The body also of one of the others, shot at a later date, was rescued fron a bear, who intended to devote it to his own use. Several bears had been shot during my absence, and their eareases also served to inerease our supply of dogs' meat.

The winter operations being in formal progress, and not requring the superintendenee of lieads of departments, my attention was direeted to the eonveyanee aeross the ehannel, to Cape Lady Frankin and Barrow Island, of the neecssary depôts for the spring travellers. 'This service was allotted to Commander Riehards. A boat had been stripped of every useless cnemubranec, and a sledge fitted to earry her. The depôt was paeked in easks, redueed in the stave to the utmost lightness eonsistent with security, and the day appointed for this duty was the 14th September. 'Our' hill-seouts however reported the ice to be loose, exhibiting suspieious streaks in all direetions; in faet, the middle-ehannel iee was still in notion. I must say that I was not disappointed; there had bcen a manifest pressure from, without that I must follow the motions of my predeeessor, without adequate reason, and as he laid out his caches in autumn, I must, perforee, follow his exauple. I certainly was prepared to do so, where common sense pointed it out as praetieable or urgent: neither of these were appreciable at prescnt, and the risk to men, stores, and anxicty about 
them, rendered its propriety very questionable. This fortunate eonsideration sealed its fate,-it was postponed. But in order to divert our minds to other more important matters, and to dispel some doubts in my own mind as to the complete seareh on the islands skirting the shore between this and Cape Becher, for traces of our missing ships, I determined on another small expedition, with the same force as before, intending to leave at Cape Becher a record of our late proceedings, and whereabouts, to guide Commander Pullen in his visit in May.

Having delayed until after the spring-tide of the equinox, - which period I calculated, from the record of temperatures on preceding occasions, that from $6^{\circ}$ to $10^{\circ}$ were the best freezing-points for the sea, when we might expect the ice would again be compact enough for travelling, - we left the ship on the morning of the 21st September, in the teeth of a southerly wind and the snow in our faces, with thermometer at $10^{\circ}$. I was persuaded to leave the 'Hamilton' behind, as the small pack-ice might destroy her' ; but I liad reason to regret it.

'The expedition consisted of the same sledges and crews as before, but without the surgeon and Mr. Grove, and we had only fourteen days' provision. Our jonrney lay for twelve niles, at least, over the smooth floes of Northunberland Sound, through its neck (or chamnel whenever' thaw's permit) into Baring Bay. But as this was also a service of survey, we had frequently to stop, aseend heights, and eonstruet cains: these matters will not mueh interest the gencral reader-I shall therefore skim lightly over the surface. Our first halt for the night 
was under the slope of a long tongue from Mount Percy, forming the clannel betwcen that island and the main.

The next molning we moved on to Glacicr Bluff, and Commander Richards ascended the mountain which caps it (named Blanche, after one of the Banmer ladies), whilst we wcre engaged constructing a cairn beneath. One of the erew, noticing a bright streak on onc of the stones struck by the pickaxe, exclaimed, "Gold, Sir!" As the roek was a lieavy piece of quartz, I stoopcd to inspect it; but thinking it to be mercly a vein of iron pyrites, ordered it to remain undisturbed, as I was then using the instrment, and ultimately a piece was broken off for future cxamination. 'The large piece was also inserted in the pile, with a case of pemmican, to await on return. There was little fear of descrtion to these diggings! Howcver, I kcpt the development of our riches for our return. On this expedition I also brought the dog-sledge and three of our Cape York dogs, which carried me and about forty pounds' weight of instruments rery clevcrly. From the summit of Mount Blanchethe highest in this region-Commander Richards liad a good view, reporting "the ice close and apparently firm."

This Point received the name of Pemmican Station, and is the eommanding jutting tongue of the northern narrows, or the pre-supposed neek of what we had believed to be Percy Pcninsula, but now clearly defined as a very narrow boat-channel.

We pitched our tent for the night on the onter head of this entrance or bight of Baring Straits (?), giving it the name of Point Repose. The terraced nature of the land here afforded good shcltcr, on fine gravel, from 
eastcrly winds; and bcneath, in varmer times, a very snug little yacht harbour might be available within a tongue of projecting shingle. But the iee on which we were now to try our chance was most unpromising. The 'Hamilton' could only have been eonveyed on her own carriage ; indecd, would have been deposited herc pro tem.

On the morning of the a3rd we advaneed towards the outer island, the western extreme of which forms Point Sophia of the old chart. The travelling was difficult, by reason principally of newly broken young ice, of every inaginable angle, cementcd togetler by the late frosts. Over this, as it jarred my limbs walking, I tried the dog-sledge, which answered admirably on the smooth ice; but meeting with an awkward lump, I experienced a most unpleasant summerset, inflicting rather a scvere concussion to my head and neck, which had been injured on the 1st of October, 1850, by a fall. As this accident occurred to the opposite side, it tended to cure it; but the remedy would not, I suspect, be prescribed, even in these days of innovation. (I have since perfectly recovered.)

We reached the island in safety, landed, and erected our cairn. I found the rock to be composed of a dullish dirty brown, sometimes variegated, swinestone, probably susceptible of polish; it frequently exhibited veins or layers of chert, the sharp fragments of which rendered it very unpleasant to travel over. As this island was one of the dreams of Penny, I retained Point Sophia, and added Cracroft Island, in compliment to his enterprising: spirit. On my descent, I found some of the party annoying a few ducks in a pool of water ; but as they could 
neither kill, nor get them if killed, I thought we might stand a better clanee hereafter by not now coming to lostilities.

Our party was now divided, Commander Richards being directed to scek the outcr point of the next large island, and shaping my own course to its inmer point, hoping thercby to save time and labonr. Our sledge broke in and wetted some articles, but we reached onr destination without further accident. The latter part of the jomrney was attended with considerable anxiety, owing to the rotten state of the ice. Commander Richards lad a cold bath; and even when we lad reached within a few yards of our destination, landing was doubtful, and only effected nnder great caution, taking some of the light weights first, over the new bay ice, by the dog-sledgc. Having encamped, I ascended the highest hill, whieh commanded a great range, and obtained my observations. The temperature fell to $8^{\circ}$, and our prospeets were at present propitious, with every probability of the iee strengthening. It is, perhaps, venturing almost too much upon English ideas of tcmperature, but it is no more strange than true, that, with this temperature, $24^{\circ}$ below the freezing-point, some of us were wishing it, at least for a period, lower! Our presumption, possibly, was to be punished.

Beforc morning on the 24th Septcmber we had it at $20^{\circ}$, with a strong breeze from east, and muel snowdrift. I began to feel great anxiety about Commander Richards and lis party, having given him instructions to proceed on to the projecting point of the next island, if lis work was execnted in time. Mr. Loney was dc- 
spatched to seek him, and luckily finding him at our opposite point, delivered my instructions to rejoin me with all despatch. This indecd was imperative, as he was on the most exposed part of the island, and was but too glad to reach our more sheltered position. They encamped beside us near noon.

The result of this galc, with temperature increasing, was obvious. The ice gradually broke up, and drifted away piece by piece; and "short commons," if not worse, was to me apparent. I did not hesitate on petty measures, but instantly ordered the reduction to half allowance, and our attention was further directed to the best mode of relief. My own plans had been already formed; I thereforc merely dropped the hint that I intended to build a boat,--leaving any brighter intellect to "furnish plans and cstimates."

Unless ealm prevailed at least for three days, aided by low temperatures, we had no hope of eseapc, even to the mainland! It is true that the entire ice had not yet broken up, but it would not bear our weight, even aeross to the southern island.

September 25 , Saturday.-The wind abated ; temperature $11^{\circ}$ at noon. The sergeant wounded a walrus, but it was beyond our reach; and several eider-ducks were swimming in the pools, but as they could not be obtained, even if killed, orders were issued to reserve the ammunition. In the evening the wind shifted to the northward, and the temperature fell to $8^{\circ}$. The slumbers of those who slept were probably pleasanter, but prayers for lower temperature, or inlense cold, possibly had not before been so devoutly offered (?). 
September 26.-This day was calm and serene, but the sun's bright rays had little eharm for us. I strolled to the eastern point, and found the iee strong enough to bear three men, who walked across to the sonthern island. But on their return, their report proved but a damper to our hopes: the channel between it and the main was "open water." The evening was beautifully elear and serene, but the wind again drew round to east, and the temperature rose to $13^{\circ}$, - sure indication of further bad weather. About sunset I shot a wah'us, which remained on the floc-pieee probably mortally wounded, but we were unablc to reaeh it. At dark, about eight, and again at nine, roekets were sent up, to indicate to the ship our position and want of assistance. From the hill-summit I thought I eould see Mount Beaufort, or the land immediately behind her; but our hopes were vain-our eyes werc strained to no purpose-no reply! Once I was mistaken by the sudden unveiling of Venus, just at the spot where I expeeted to diseover the signal or burst of the roeket.

Early on Monday, the $2 \%$ th, the wind inereased, with snow, sleet, ete.; ice breaking up, and swceping past us. The shout of " A walrus elose to, and drifting in-shore," eaused 110 little exeitement, particularly amongst my own energetie men. Bond, the iee-quartermaster, aided by amother, put off on a pieee of loose ice, with a line fast to the shore, and succeeded in hooking it with a boat-hook, by whieh means he drew it to the shore, where it was soon seeured. No sooner was this donc than some few more oozed out of their bags. But this did not suit. "All hands sccure walrus!" brought each 
man to his duty, and the agreeable monster was seeured, ent up, and deposited at the tents-a most aceeptable boon in every way. It not only seeured our existence until the iee re-formed, but afforded plenty of that next blessing to food, the means of eooking and obtaining water-fuel. Now might be lieard the diseussion of who killed it: of this I cared not,-we eaught it, and it was yet warm, and good foor. It had been shot in the throat, a wound generally fatal, and eausing them to seek the floe to die. Another gratifying feeling was also afforded me-that our dogs would find sustenanee; for the loss of them, by starvation or eompulsion to kill, would have distressed me eonsiderably, next indeed to personal misfortune.

It eontinued to blow hard, with sleet, rendering our labours very harassing; but aetivity and employment for mind as well as body must be found. I had great diffienlty to eontend with. Snow-walls were ordered to be built round our encampment; and, as it oeeurred to me that this would prove a eonvenient moment for praetising our men in house-building, I superintended personally, as ehief mason, in this praetiee.

On Thesday, the 2Sth, the wind shifting more southerly, and 110 "plans or estimates" for the boat having been sent in, I proeeeded to work in my own way; and I must say, although the others volunteered, when she was eonstrueted, to eommand her, that Mr. Loney did so before I eommeneed, in the full eonficlenee of sueeess attending. However, volunteers do not guide me; I seleet those to whom I intend to entrust the duty, and Commander Riehards would have been seleeted. 


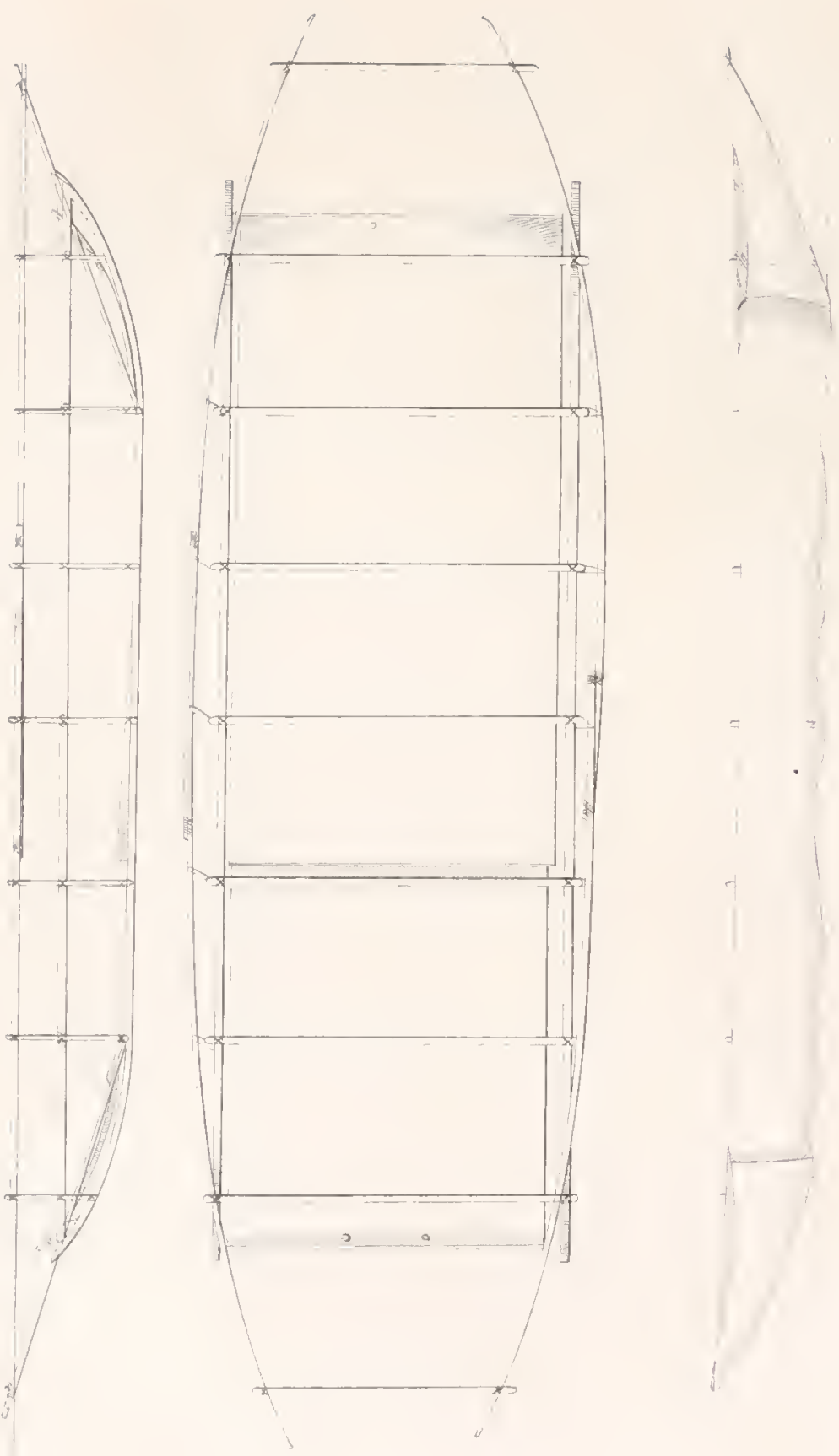
Taking one lumner-sledge as my framework for an oomiak, and two flat sledges for the ends, it will clearly be secn that the rudiments were in a state for completion; ribs werc thcn brought up at each runner-bearer, rising about one foot above the sledgc; and to this, oomiakfashion, I formed my gunwale by four light spars, two of tough China mahogany, and two bamboos used for yards, for sledge sails: by a little straining these rere brought nearly together at cach end, and cross-pieces lashed. It was, indeed, to those ver'sed in Esquimaux boat-building, the oomiak; or roman's boat. It only remained to cover this properly; this was effceted by the canvas-bottom cloths and Mackintoshes of the tents, so as to form two laycrs.

The object was, to convey to the main a party with onc day's provision and their slecping-bags, who would walk on to the ship and forward to us in due time the neccssary relief. As the three leading officers of the ressels and twenty-seven persons werc thus cut off, I determincd to remain alone with my own men and Mr. Loney, sending Commander Richards, Lieutcnant Osborn, and any others who could not eat walrus, by the boat.

He was to have started enrly the next morning, and his orders were already writtcn; but as the cquinoctial spring-tide here would not occur bcfore 2.30 on Thursday, I detcrmincd to defer it until that cvent had passed. To oppose the antipathies of any set of men, is absurd, -is naking them of too much importance. I dislike pcminican,-never would touch it if I conld avoid it, becausc I consider that it is, to me, unwholesome food; many of my crew also refused it for some time: I con- 
timued to eat it for example sake. Others also dislike partieular birds. But my prineiple invariably is, to endeavour to make anything fit for food palatable, and, setting aside my inelinations, to make it suit my purpose. I would not prefer whale or walrus flesh to the best beefsteak, but I would most assuredly prefer the best whale or wahus to many meats termed beef. Of this walrus I not only partook heartily, but I think that I overeame the objection of many, and that thereby they gained a wholesome and nourishing food, instead of semi-starvation. I had almost forgotten to mention that, in order to prove our boat, I started with four hands in ehase of some dneks in the open water, killed four, and a grey doveky, whieh were divided as four would be by three, the lawyer taking the remainder for his pains; they afforded, with wallus and baeon, a very aeeeptable meal.

On the 29th we experieneed strong gales from eastsonth-east, whieh eaused the iee to break up rapidly and drift off. The tide at noon today rose beyond its ordinary level, carrying off all the heavy grounded masses of iee, and denuding the shores of the island to the gravel; an oeemrenee of sea-washed beael not witnessed by us sinee the 28th of August.

On the 30 th, the wind having ehanged to the sonthwest during the night, the loose iee packed in upon us, and toward the evening it moderated greatly, leaving a fine, elear night, with a temperature of $22^{\circ}$, but mueh too warm for our exeited feelings. At nine I made the preeoneerted signal to the ship for assistmee, viz. two roekets. Venus showing between the passing elouds at 



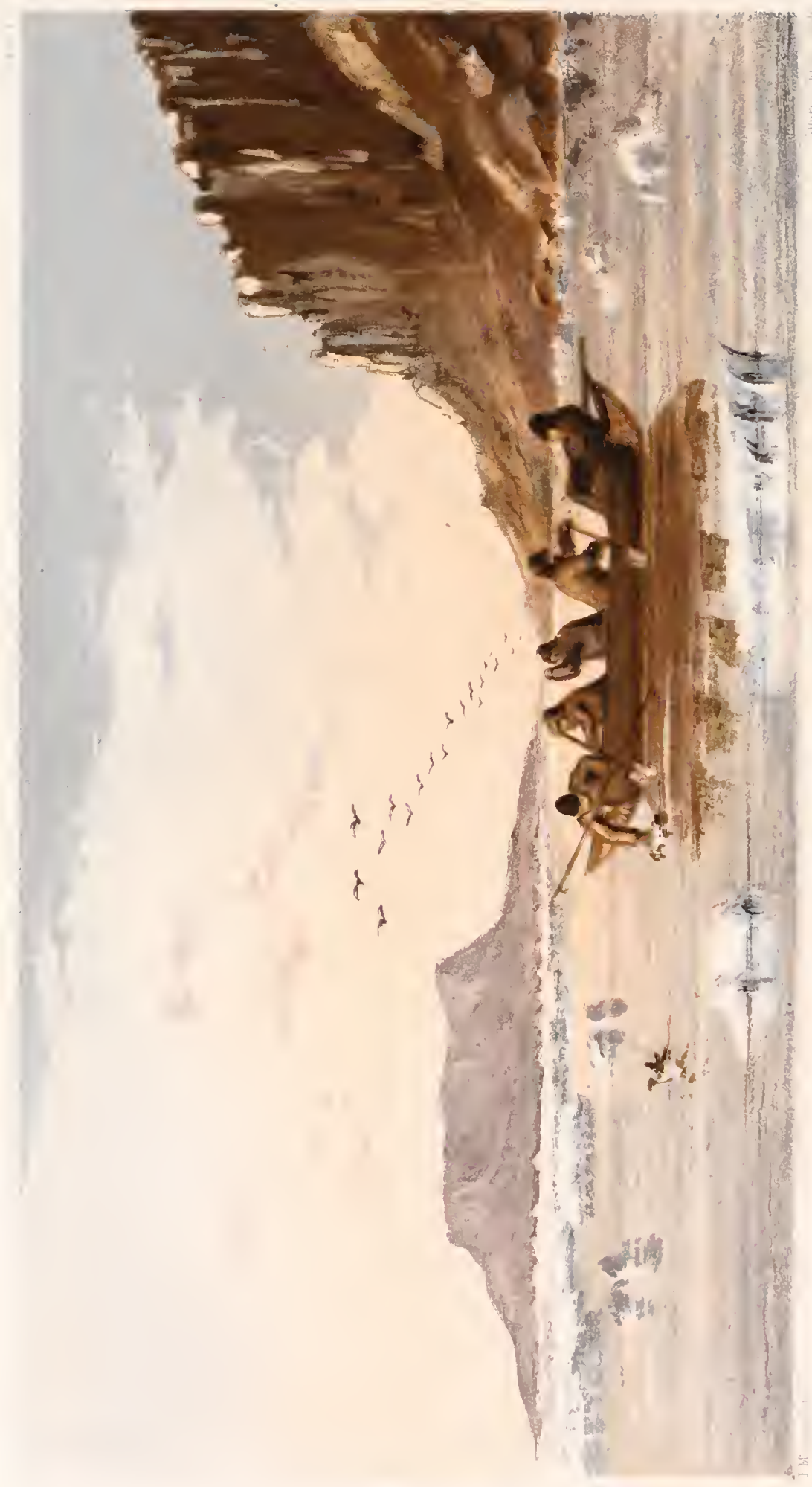


the very spot where our attcntion was dirceted, afforded the suggestion that she accepted the compliment. But nothing of this naturc from the ship was noticed,-a matter becoming about this moment painfully exciting.

I had onitted, amongst sneh serious considerations, to notice the launcl of onl new vessel. It is usual in lower latitudes, or in the regions of the grape (or even of malt), to christen such bantlings with the customary honours; but on the occasion of our launch therc was nothing at hand but snowballs, and in sober sulkiness she took the water: under the appellation of "The Eidcr Duek.'

Commander Richards became very anxious to make the attcupt to cross; but with the rough packed ice this was not safe. Indeed I had determined not to risk our all on any ill-considercd experiments.

On Sunday, the 3rd of October, was onl day of rest. Many solicitations to cross were repcated; but I had no confidence in anything around me, and I felt that when I ceased to conmmd, then the spirits of my best men would flag, and that wherc difficulty and danger was to be braved it was my duty to lead. Besides, some undefinable fecling prompted me to delay: who shall attempt to unravel this curious or rather mysterious habit which has followed my fortumes? I was firm; providentially, I must add, I deferred until the morrow.

On the 4th the temperatures fell successively from $16^{\circ}$ to $4^{\circ}$; but the ice, although frozen in many parts, still exhibited very suspicions cracks. Unaccomntably I had now arrived at my determination,-why or wherefore, to mysclf is inexplicable; moreorcr, it was still more 
ineomprehensible that the advoeates for crossing yesterday were now adverse! But that mattered not; I felt quite assured of the practicability, if I could cross the band of smooth iee intervening between us and tlie pack, but that would not bear the weight even of one man!

The order "Down tents!" was the first indieation of my resolve. 'The ice was broken, and a eliannel for the 'Eider Duek' eut by spades; it closed, was cut again, and cventually, not without much trouble, all our effects were ferried by our valuable oomiak to the solid ice. The 'Eider Duck' underwent immediate transformation, worthy of any pantomime, her various parts resuming their duties in the sledge equipment. Moving forward in riglit earnest towards the main, we reached it, and lunched on the "land-floe" at noon. Every one has his peculiar feelings: we liad crossed many cracks, escaped many serious difficulties, solely by dint of that activity which results from the imnate fear of losing all. We thus quitted "Hungry Island,"- - a name which I do not think even Penny will dispute.

I must believe that every individual had his own earnest feclings as each touelied the safe shore, or land-ice. For myself, I felt that the meal was more solemm than usual. Such sensations are better left molescribed, for neither the feelings nor the pen can execute their duty.

Our actual difficulties were yet to be eneountered, but we knew them not. Several wettings were expericneed, and at nightfall, on reaching our most critical position, we had not found safe landing for the sledges, which still lagged behind. Fortunately I was in advanee with my dog-sledge, and, trusting to the instinet of the ani- 
mals, which refuse unsafe ice, thcy sclcetcd a safe passage; I landed, and, establishing the ferry, sent the dogs back with the driver to convey our equipment by light loads on this sledge. Frequent trips increascd confidcnce; for scveral had fallen in and got wet, and our sleeping-bags unfortunatcly shared the same fatc, my own, I believe, amongst the number. Eventually all were safely landed, and our tents pitched at Cape Repose. Beforc ten, I think, thanks to an overruling Providence, all were safely landed; for I am convinced that no security could have becn found that night on the ice, the tempcrature laving again risen to $23^{\circ}$. Many indeed lad wet beds, but with our warm suppers this was now but a triflc.

On the morning of the 5th I despatched Commander Richards with the other sledges to the ship, with two days' provision, reserving the remainder to completc our survey. On examining our old quarters, where we had deposited the dogs' food, we found that it had been robbed by bears; but the dogs laving devoured their full travelling allowance of walrus at Hungry Island, this was less important. Our subsequent motions being but matters of survey, I shall pass them rapidly. In our advance to the ship, we called at our North Californin for our pemmican, and to seck any further specimens of the precious metals which might turn up. In the latter search I was unsuccessful. The temperature, having fallen to $4^{\circ}$, was in itself sufficicnt to cleck any ardent pursuit after metals; they bite as sevcrely in cold weather as gold does in California or Austratia. Abont nom we net a relief party from the ship, under 
Mr. Herbert, mate, and Mr. Rieards, assistant-surgeon. Moving along the coast, we slept in the Sound; and at cight the following morming, starting for the ship with the dog-sledge, were again met by Messrs. Groves and Pym, who most kindly and charitably shared with us a very aeeeptable luneheon of sandwiehes and sherry. About eleven we reaehed the ship. Never did I cnter my cabin with more unfeigned thankfulness; not for mysclf alone, but for the safety of the fine set of men who had shared our misfortune, and whom this partieular branch of the Expedition could so ill afford to lose. 


\section{CHAPTER VI.}

The 'Assistance.'-Winter Fittings. - Moisture between Decks.-Meteorological Investigations.-Tide Gauge._-Inatomical Shrimps.Washhouse.-Thoughts on Arctic Fittings.-Terraced Levels.Effects of Tidal Action.-Tidal Fissures.-Experiments on Ice.Last View of the Sun.-Her Majesty's Arctic Theatre.-A Gale.The Observatory.-A Snow-storm.

Our own miseries terminated, turn we now to the good ship 'Assistance.' As I had anticipated, the ship had not been a whit too sccure, and the absence of our party might have entailed ccnsurc on mc, had any serious mischief occurred. I was informed that the ice had broken up to within a hundred yards of her bow; and that, in the expectation of its proceeding further, warps had becn carried to the main floe to secure her. Had the icc broken up herc, as it did at Hungry Island, there can be no doubt that she would have been driven on shore; but the want of tide prevented this. As it was, the icc had cleared ont up to the southern point of the Sound, and a sporting party had visited it in onc of the boats, but without any view of relieving our necessities.

Any of the above misfortunes, vicwed singly, might be deemed trivial; but the loss of the principal petty 
offieers and myself might have very mueh ehanged the results of this Expedition.

Our attention must now naturally revert to the eompletion of our winter arrangements. 'I'he temperature had not yet afforded sufficient proof of the neeessity of eovering our dceks with snow, or building walls round the ship: of the propricty of both these matters I entertained my doubts, and wished further experienee before I eommitted myself. Of the advantage to be derived from a good snow-wall, distant about a foot from the sides, and suffered to fill in with light snow, I lad little doubt; but the plastering on a non-eonduetor a solid body of fine iec, sueh as the snow-embankment arrives at eventually, eould not prove of mueh importanee. The matters eomneeted with winter fitting have never met with a due amount of deliberation in England, or I fecl well satisfied that much better arrangements for sceuring the health, as well as eomfort of the erew, eould be attained by more simple as well as effieaeious means tham those gencrally adopted. But these matters should have had full eonsiderntion in England, and the means for earrying them out provided. Beside this, there is a kind of awkward responsibility attending innovations of this nature, whieh, unless founded on something stronger than mere authority, would induee restless writers to attribute every misehief and miscry, however remote from eommon sense, to the innovator. Under sueh reasoning, the only alternative is- "If they were miserable and siekly before, Captain — found he eould not remedy it; and therefore, however eomfortable the eabins of the captain and offiecrs may be, matters must be conducted 
as they were by their predecessors." Now, I am firmly of opinion that Sir John Ross was right as to his systcm of ventilation, but carried it on mpon such a reduced scale that it could not act sufficiently. And I feel fully satisfied that the evil in these vessels might be remedied by hatching the present decks, and in winter removing the crews six feet lower. Such a disposition would avoid the immediate condensation of breath on the lower deck beams, resulting in a constant dripping on the lower deck, and, at night, soaking the ber of every man sleeping there! Undue wet and pervading moisture, and that too eharged with the customary constituents of the breatl of men, is but too well known to be the predisposing cause of scurvy; and yet, knowing all this, will it be credited, in the last portion of the nineteenth century, that horse-sponges are supplied to wipe off this moisture? - a thing only to be discovered in October, when thesc drippings commence, and when the daily doleful report of the surgeon is, "She is so very wet between deeks, Sir." And, as if this should not be a sufficient warning, I find that vent-lioles, to let down cold air, to increase and keep up this condensation, are actually opened, when the heat below camnot be maintained at $40^{\circ}$, and was frequently, cven in my cabin with a stove, below $20^{\circ}$.

This season may pass, and, I sincerely trust, without any material mischief; but should it be our lot to pass another here, I have fully made up my mind that, having given the plans of my predecessors a fair trial, a very different system will be enforecd, for the futurc comfort of all. 
As Lieutenant Cheyne had brought with him-supplied, I understood, ehiefly from Kew-some vcry delieate eleetrometers, I determincd that he should have cvery assistanee the serviee admitted for attending to the influenee whiels the aurora might exercise. To ensure this, he was exeused from other duties, and direeted to attend to the registry of thermometers; and as it would be ineonvenient to send offieers aloft to register thermometers, I adapted a balanee-pole of twenty-eight feet in length, so that it eould be easily pulled down ; to this a minimum thermometer was attached, to be read at eight A.M., at noon, and at four P.M. Another plain thermometer was also fixed at twenty feet, and one of the standards was placed on pikes at four feet above the earth, near the Observatory, independent of the general board, containing fifteen standard thermometers from Kew and Greenwiel, under the boat. The pike-thermometer was registered hourly with the magnetometer. A very delieate electrometer was also placed in the Observatory, but was broken not many liours after by the prying euriosity of some meddler.

Before the Stli of Oetober the general observations on the magnetometer were supposed to eommenee; at all events, the registry dates from noon of that day. The offieers who voluntecred for that duty were Lieutenant May, Mr. Herbert, Mrr. Grove, Mrr. Pym, mates, and Messrs. Harwood and Webb, engineers, of the 'Pioneer.' The observations were eontinued hourly, both night and day, throughont the winter, up to July. Various other observations were earried on by myself, at the instanee of Mr. Glaisher, of the Royal Observatory, Greenwich, 



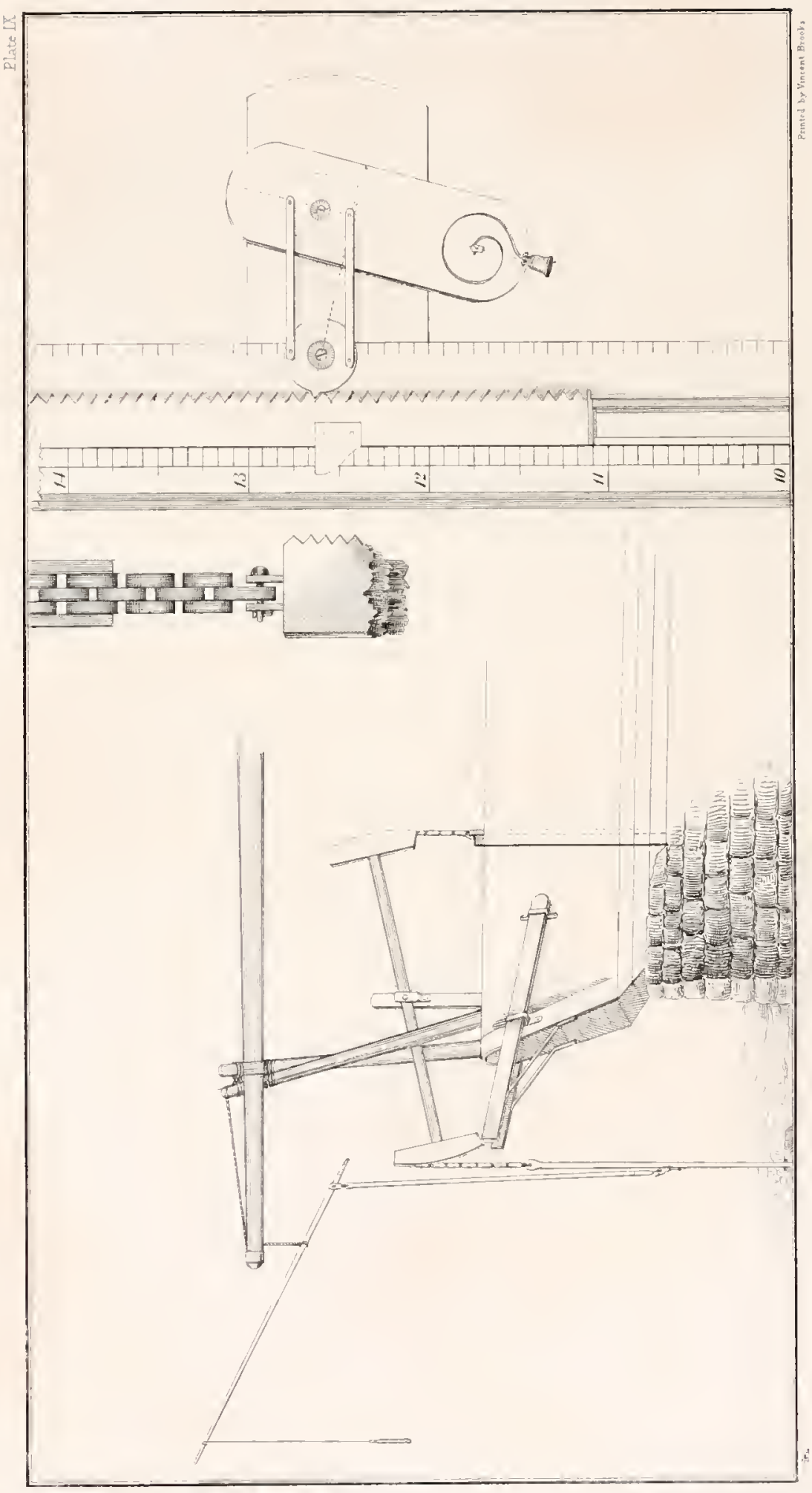


who supplicd, by authority of the Admiralty, a most valuable suite of thermomcters and other instruments, and sparcd no exertion to afford valuable information and suggestions for their managenent.

As the decrease of temperaturc would soon prevent the accurate registry of the tidcs by our tide-pole on shore, I made some expcriments on the true risc and fall of the ship, now firmly frozen into the floc, so as to guide me in selecting her as the index of floatation, or tidal level. To determine this truly, I placed the theodolite so that the level wire should coincidc with a zero mark on a batten nailed on the ship's side. This instrument being fixed, the readings at cael inch, above or below, being eompared with the tidc-pole already established near the shore, and found to be nearly identical-in fact, thosc indicated by the ship being morc decidedly evenI lad no further hesitation in adopting her as my intended gaugc. The modus operandi instantly occurred to me, and I at once determined to make it a plaything or complete piece of miachinery. 'I'his required a little labour in my eabin, but it was soon eonstructed, and told its own tale, marking the inches of rise or fall by agitating a bell. As it will be better understood by a diagram, I must refer my readers to it for explanation.

All seamen will understand the natter without difficulty, but I fear that I may not bc so fortunate with civilians. It must however be apparent to all, that by affixing a large as well as heavy weight to a rope, and sinking it to the bottom, the weight, provided the bottom be firm or gravelly, would gradually acquirc a steady position by agitation. This donc (at $a$ ) below water, and 
previonsly well secured, a good spar was lashed to this rope, and a fair strain kept on it for some days. The rope thus became frozen like a solid wire; the upper end of this pole was connected by an iron clasp, with a flat moulding or clock-chain formed of oak and copper. To ensure its being at all times perpendicular, as in pump-work in mines, ctc., the radius pieces $b 6$ were attached with chammels for the chain to work in. This balance-beam acted in a metal-formed crutch, with pill, and was attached at the inner end by a similar chain to the gauge-rod, which alone was sufficiently ballasted to prescrve a steady and even strain for the descent of the gange. Extcrnally, to kecp the pole steady to its work and at a constant tension, an additional leverbalance was cmployed, with a strain cqual to $56 \mathrm{lbs}$. It is elear, then, that the bottom weight being too heavy to be moved by any ordinary force, that the rise of the ice, or ship, must draw up the index-bar; and, being of itself considcrably heavicr than the outcr pole, ete., the descent of the ship must canse it to fall. All this being covered by the housing in-board, was protected from snow or any other inconrenience, and the gauge occupicd on the quarter-deck the position of the wheel-unshipped for the winter. Beside it, was a temporary table and a lantern, illuminating the graduation, and cuabling the person watching to register it. But our mode of registry, by equal altitudes, requiring the time at each inch of rise or fall, a ratchet, or notehed edge, was cut on one side of the movable slide, which acting on a one-toothed wheel, caused it to draw from its perpendicular a planc board, at the lower end of which a 
spring-bell was attaehed. At the instant this tootll became released, at the passage of the ineh division, the board, ballasted with the bell, in its attempt to reeover a vertical position, vibrated over the deseribed arc, and eaused the alarum to warn the observer to note time. At one period I contemplated leading it by a fine brass rod into my eabin, but I soon found I had quite enough of other matter to oeeupy my attention. After this had acted satisfactorily for some days, in eomparison with the gange on shore, the latter was removed, the iee forming too fast about it to be of further use.

The gauge in the diagram is aseending past twelve feet seven inches; at twelve feet eight inches the bell, being drawn up to the side of the gange-frame, will vibrate, on its relense, nearly to the same distance that it was drawn out of the perpendienlar, the tooth of the whecl being so ealeulated as to pass freely at the instant of release at each inch, and is not taken up again until it has moved over a quarter of an inch. 'I'his alarum eventually beeame troublesome, and, finding the attention of the observer could be ensured, it was latterly muffled.

Our speemen-net was sent down, charged with the heads of bears and other animals, to be cleaned by the shrimps, as they are termed, but a speeies of Oniscus or sen-louse. Two eels* were taken, which rather diseountenances the idea of their not bearing cold; I am not quite sure, however, that they were truly eels. The take of these erustacea was so plentiful, and they were so large, that some of our gourmands attempted to substitute

* This question not decided. 
them for shrimps; and they possibly answered quite as well, if the shells at least arc eaten in both cases: De qustibus, etc.

The washlousc for the crew was constructed on shore, composed of blocks of snow, now sufficiently frozen to be easily landled, and eut by snow-knives into any requirch forms, much resembling the working of very soft Gloncestershire oolite. Unfortunately our Surveyor-General of Works had miscalculated his ground; and aftcr the walls were up, the rise and fall of tide causcd eertain ominous gapings in the gables, whieh was but partially remedied by disconnecting the land-floe by a ditch. However, this not being deemed satisfactory, a new inner wall was constructed, making another parallel room or donble house. This is another feature of Arctic arrangement which does not suit my views of economy of fucl, of comfort, or sound judgment. First, the expenditure of coal is wasted out of the slip); next, the mon are sent to light a fire with wood, etc., in a cold house, and expend half the fuel before the copper is warmed. The temperature therc is too cold, especially whon the thermometer falls to $62^{\circ}$, for such operations as washing; and before the clothes ean bc wrung properly, they are a mass of ice, and the shivering unfortunates arc seen, with their clothes half washed and iee-bound, wending their way across the floe to the ship-for what?-to carry below into the main hold, beside the Sylvester apparatus, these masses of ice, to be converted into vapour, and diffused betwecu deeks. Verily, there are too many ways of inviting siekness withont this!-but "it was done before," is the reply. 
I purposely introduee these remarks, not in any manner as a refleetion on nyy predecessors, who, I am eonvineed, were quite as mueh alive as myself to every preeaution for the preservation of the lealth and eomfort of their men, but to slow what a very diffieult position a man of eommon sense is plaeed in, when he aeepts sueh a eommand. He ean liardly be deemed a free agent ; he is pestered by assertions that sueh was the eourse Captain H. pursued; and if he either doubts, opposes, or varies from these self-eonstituted Mentors, he must look for sulkiness, opposition, and the petty mutiny of petty minds. It is this underhand tyranny attempted on the chief, that lias made so many offieers deelare " that no indueement would bring them here again." It is the duty of every man who may eommand suel serviee to institute a full and eomplete imquiry into all its workings, and, if able, to afford suel information as may be of serviee to his sueeessol's.

But sueh matters are not merely to be eonfined to Aretie vessels. The same prineiples, narrowly watehed, are involved in every ship and every private dwelling; it is a sanitary question, and must stand on its philosophieal merits alone. I do not, at this late period, begin my refleetions on these matters; I earried them out sueeessfully between 1830 and 1S33, three years and a half, on the eoast of Afriea, without the loss of a man, and have been generally sueeessful in other ships. Another season may afford different results; I will then-stubbornly, no doubt some will say--put in praetiee my own views. Doubtless this work may eontain many theories not at all in aeeordanee with the views entertained by VOL. I. 
those luxuriating in warm studies in $52^{\circ} \mathrm{N}$., with a tcmperature of $76^{\circ}$; but it is my business to present facts, and very stubborn facts too, with the apparent causes in operation to aecount for them.

The washhouse brings me baek to the fact of its rent at the gables, the sides being parallcl to the bcach-line. Onc fact is worth a thousand theorics, and such a fact, too strongly pressed on my mind, placed me in great doubt as to the fatc of my Observatory,--that is, should the iee mareh up-hill, and imperceptibly slide it over its gravelly foundation, or disturb its level in the smallest degrec perecptible.

In order perfcctly to understand my fears, I may as well exhibit my vicw of the causcs whieh, throughout the Arctic scas, in pcrfeetly sheltcred as wcll as cxposed bcaches, produce the lower terraced levels at, and immcdiately above, the flow of the sca. In a pool, land-locked, possibly never sca-washed, by reason of a very narrow belt of water showing only in summcr at high water between it and the then floating icc, it is cvident no such modc of throwing up gravel in complete tidal strata could be effected, nor evcn in exposed beaches has the sea any such aetion, for similar reasons, viz. want of water in sufficient volume, or range, to raise these tidal or beach lines. When I first entered these regions, this matter engaged my attention from the summit of Cape Spcneer to the beael. The only rational mode then appeared to be the melting of snows, - the formation of successive terraces, confining the watcr, and its successive similar steps, until it reaehed the sca. Since then I have thought more, and seen part of the lower operation in action; 
and I have rejeeted all the former conelusions, beeause these are not invariably, even in winter, "snow-elad" regions! The discussion of the eauses operating on upper levels must be refcrred to other authorities and forees, and, as far as I know, must ever remain theoretical; no proof can exist.

The first eause is plainly illustrated by pressing a flat board, having a smooth reetangular edge, against a slight ridge of sand on a table: this will produce the first ridge, or terrace. Possibly the inncr edge of the board may lise, and slide up the sand some inches: comparing great things with small, this is Nature's first movement here. The fine bay ice, say six inches thiek, forced very slowly by millions of tons weight and impelled by wind or tide, presses on some beach, a noise like that of a rushing wind is instantly heard, and icc is noticed travelling up the beach, foreing before it all the light grave]. This of course planes the subjacent matter. It has possibly removed one great shaving, and the upper abutting gravel resists but for an instant,-it buckles, breaks, and turns up, forcing layer after layer, and "piling" the beach until the motive power is arrested, possibly miles distant! This is Act I.; it may be repeated, and the suceessive forces, possibly with planes of four feet in thickness, do their work with unerring certainty, until arrested by the general freczing of sueh a mass so accumulated on the shore as will compel the outer icc to buckle, break, and pile, overwhclming the strongest works of man. These are plain, unmistakable faets. The spring thaws reveal these faets-these apparently "tide terraces," and leave new comers to dream of their origin. 
Such an operation of Nature at the beach, and partieularly in our sitnation, would inevitably destroy the Observatory, pcrhaps leave no hope of saving the instruments; but this. I did not antieipate now. 'The bay or land ice had formed, and the planes for this season would not in all probability be disturbed to any extent; but it was to be feared. Anotler cause in daily operation, and acting to the same end, was in quict, irresistible action : this was the tide. If the elder Perkins is alive, he may remembcr explaining to me his earliest invention, the cotton-pressing machine; I think it may still be seen at the Polytcchnic Institution. Such is our tidal ice-power, the "taking up wedges" being the snow-drift, etc., which fills in as the tide opens the various fissures following the contour of the coast margin.

Let it be conceded that a grcat and continuous space at high water is frozen, and that the established winter ice, grounding daily in sixteen feet water, causes gaps varying from one foot to six inches, in contour hines eorresponding to the depths surrounding the land. It must be evident that these gaps, if filled up, must at each returning ligh water (twiee daily) foree the in-shore ice up the inclined plane equal in amount to the interposed compressed matter. This we found it did, until the heavy ice formed, to guard the in-shore line which it had taken up. Then these gaps presented another feature: they turned up, or rose above their in-shore grounded pieces, causing, wherever resistanee offered, unpleasant barricrs. The upper erack of the ice-hine eeased about six feet from the Observatory steps. I cannot state preeisely how many yards it was from high-water line 
when I seleeted the position, but it certainly was six feet above the level of the lighliest tide.

H W

L. W

Supposing the upper line to represent ligh water; the second to indicate the thiekness of iee; next, the centre line to indicate low water, and the third its under surfaee of iee; the breaks on the shore would indieate the natural eauses operating to eraek ; the upper dots, the early stealthy movements up-hill, as evident in tidal pools.

The preeding natter may be dry, but I am not aware that any previous navigator has attempted to explain the causes in aetion; and if I merely sueeced in drawing the attention of enlightened men, - not of those irritated by the truths which demolish their theories,-I am fully repaid. I eannot say, $E x$ fumo dare lucem; but they may blow the smoke from our eyes by enlarged diseussion.

That the floe had moved in-shore I had absolute proof before I finally removed the tide-pole; when it was plaeed, it had an inelination seaward, and the pole was at the baek of the hole; when removed, it had about the same inclination in-shore, and we had to cut away the outside part of the floe: this would not afford at that spot, afloat, more than one foot. One very curious faet was the deptli to whieh we had to dig to get out the triangle legs,-three feet perpendieular. The question then arose, where does the inerement take plaee in freezing? I am ineliner to think, in the early season, botlı 
ways,-upwards by evaporation, and below by the customary process of freezing; but here again we have a very stubborn fact to contend with. By all the experiments made, until I became sick of reported breakages of thermometers, I could not detect a well-attested difference between the temperature at the bottom, in seven fathoms, and that at the surface. If heat ascends, and the cold will not descend through ice below $32^{\circ}$, the sea preserving $29^{\circ}$ to $29 \cdot 5^{\circ}$, why does it not freeze to the bottom? and why does it accumulate on ice freezing at $28^{\circ}$, but only at $32^{\circ}$ when frozen? Our experiments have not resolved this difficulty,-every trial has been marred by some mistake.

Cubes of Ice.-Experiments were now commenced on eubes of sea-ice, and, as the thickness increased, they were extended to the nean upper, mean centre, and mean lower masses. Nor did it cease there. These cubes, duly numbered, were exposed to the upper-deck temperature during winter, and weighed at particular seasons to deternine their ehanges by exposure, evaporation, etc. The water resulting from thawing these respective divisions of the iee was bottled, as well as that at the surface, for future examination. The atmospherie air, in well-dried, stoppered bottles, and covered with lcather and bladder, was also obtained.

On the 25th of October, a cubic structure was formed with snow bricks, of twelve feet in length, ten wide, and six high, the crevices being sealed with snow and water. In this mass five Six's self-registering thermometers were inserted, equidistant in height as well as lateral distance from the air, as follows:- 
No. 1. 5 feet deep and 5 from the side.

$\begin{array}{llll}2.4 & , & 4 & , \\ 3.3 & " & 3 & , \\ 4.2 & , & 2 & ", \\ 5.1 & , & 1 & ,\end{array}$

A hole had also been eut into the roeky soil, in whieh a wooden tube four feet in length was inserted, in order to determine the maxima and minima dnring the winter season. But, to my surprise, I found that it had been registered with the other thermoneters daily. However, it was finally sealed and seeured from further molestation on the 2Sth of November.

On the 27 th of Oetober, the sun should have been in bed; however, I eould not resist "one last, fond look," and as he displayed his eountenanee for the last time, his altitude was observed, giving about 31' $31^{\prime \prime} 5^{\prime \prime \prime}$ refraetion.

Our winter had now eommeneed : the thought brought with it many last expressions on quitting home, eonneeted with the return of that luminary, not easily forgotten! This is not a region to ehase away sueh intrusive refleetions; but they only nerve us, perhaps, in remembranee of the many mottoes, to persevere, to do, and possibly, to deserve.

Dates will now pass rapidly, although our time will be eompletely engrossed by matters too tedious to detail and too heavy for the general reader. I shall therefore go back to the before-mentioned washhouse, where I found that Commander Riehards leeld some mysterious meetings, whieh sedneed from their allegianee several subjeets of my Observatory. It was too eold and dreary a spot for me to pry into. At length however the murder eame out: he had beeome the Sole Lessee and Director of Her Majesty's Theatre Royal, and had there 
established his green (?) room. In due time the clattering of carpenters and other employés rushing to and fro was heard; and, near the commencement of November, the following play-bill, printed at the Royal Press, on satim, was placed on my table, ordered to lic there, passed three readings, and received due assent, the Lord Chamberlain having no objections thereto.

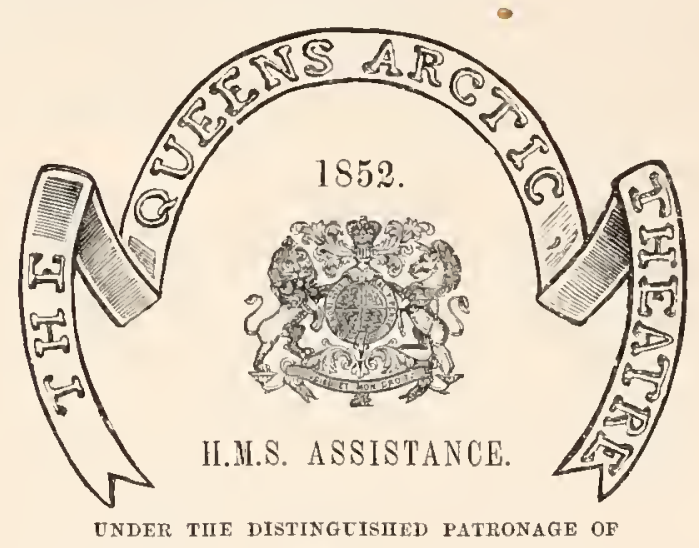

CAPTAIN SIR EDWARD BELCHER, C.B.

Commander G. H. Richards, of the Royal Arctic Navy, (the Sole Lessee and Nanager, has the honour to acquaint the Nobility and Gentry of North Cormwall that he has, at a eonsiderable personal saerifice, and with the almost sole view of eontributing to their entertainment, cngaged a highly select and talented CORPS DRAMATIQUE, and has entirely rebuilt and re-embellished the Qneen's Aretie Theatre, and that on the Ninth of November, being the birthday of

HIS ROYAL HIGHNESS THE PRINCE OF WALES, DUKE OF CORNWALL AND EARL OF DUBLIN,

will be performed, for the first time in this country, the inimitable

Comedy of

\section{TIE IRTSH TUTOR.}

FuAl ...........Mr. GROPE (of the Argyle Rooms).

Chartis. .. . . . . . Mr. ALLARD (of the Royal Pioneer Otympic). 
Mr. Tillwell. . . . Mr. LEIFIS.

$\left.\begin{array}{l}\text { TERry O'RovREE } \\ \text { DOCTOR O'TOOLF }\end{array}\right\}$ Mr. IIERBERT (the Power of the present day).

RosA.............Mr. CHEINE (an Aurora of the first water from Sadlers' Wells, where her performance electrified the audience).

MARY

Mr. II ARWOOD ner first appearanre on any Stage).

Villagers, Peasantesses, ctc. ....... British Seamen.

To be followed by

A MUSICAL INTERLUDE.

GLEE, See our oars like $\begin{aligned} & \text { Mr. J. GORE (celebrated Aretic Focalist). } \\ & \text { feathers play.... HARWOOD (from the R. P. O.). } \\ & \text { Mr. J. MACARTNEY. }\end{aligned}$

Duet, The Queen's Coachman, Messrs. R. \& I. HALES (from R.P.O.). Solo, Ireland . ........... Jr. MLACARTNEY.

Nautical Hornpipe ...... Mr. A. DiCKENS (from the R.P.o.).

After which, at the express desire of the Ladies,

The perfect Farce of

THE SILENT WOMAN.

Mr. SANDFORD . . . D $r$. RICARDS. ARTIUR.... Mr. GROTE. Marianne . . Mr. CIIEINE.

Es The Queen's Own Band will be in attendance, and a MAGNIFicent Drop Scene is being painted by that eclebrated Aretic Artist,

\section{MR. WALTER MLAY,}

for which an overflowing house alone can in any measure remunerate the Sole Lessee and Manager, who takes this opportunity of repeating to the Public that he is actuated by no fccling save that of contributing to their amusement, and realizing a competency for himself against increasing years and informities.

The House will open at 6.30 , the Performance commencing . precisely at 7 o'clock.

Tickets may be had of H. Brinnt, at the Aretic Printing Office, Winter Quarters, Northmberland Sound. 
One authority however had not been consulted - it was too late-it was the Clerk of the Weatler" I am informed that the very same mistake oeeurred "last cruise," on this identieal day too; therefore the "old lands" were to blame. One thing however settled the matter-it could not be put off-it was to open on the oceasion of the amniversary of the birtl of His Royal Highness the Prince of Wales and Duke of North Cormuall. Blow it might, and do its worst, and blow it did.

As the Play-bill intinuates, the subjeets seleeted were 'The Irish 'Tutor' and 'The Silent Woman.'

The theatre was got up with considerable taste, and every charaeter admirably supported, even to a most troublesome one-eyed pie and ginger-beer man, who most pertinaciously ehose to present limself at the Royal Box. Tle knew full well IIer Majesty and the Prinee eould not travel this wenther; indeed, he had heard the apology from the Lord Chamberlain read by the Sole Lessee, explaining the eause, and intimating her most graeious pleasure that the men should not forget Mr. Allsopp, which latter sentence was reeeived with thmders of applause. As to hearing anything, Boreas liad it all his own way: it lay prineipally between hin and a Woolwieh waterman politely intimating that " the last boat would start posa-Tuve-ly at eleven."

As we were unable to hear, it is almost needless to add that the excellenee of the aeting entirely superseded the noise of the tempest; and between it and the musie, of 'which 'Cease rude Boreas' eonld not be lieard, and but imperfectly understood by the tremulous fingers of the musieians, the evening terminated satisfaetorily. The manager, being most loudly called for, at length appeared, 



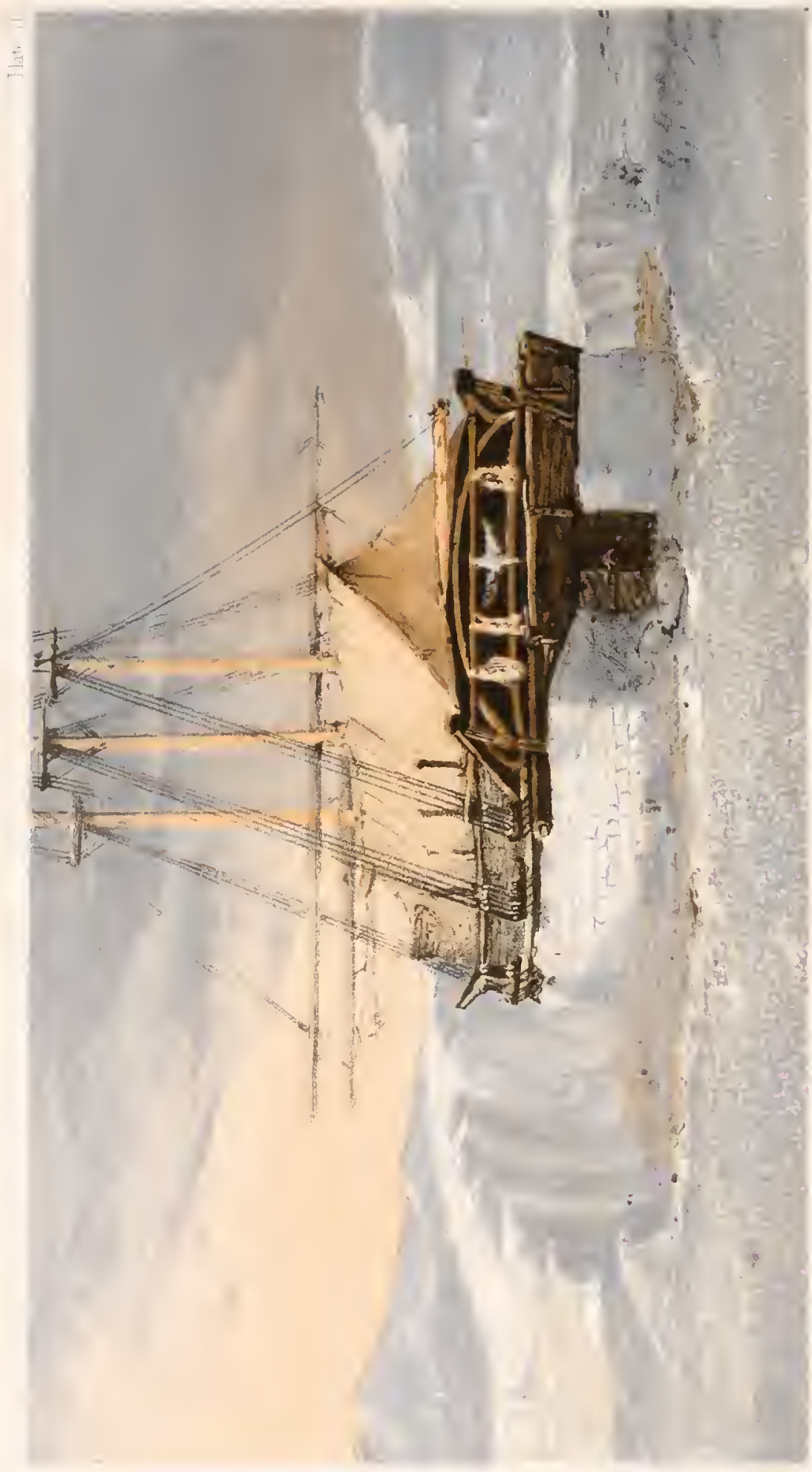


and, having overcome his modesty, made a very taking specch, not omitting Allsopp in conclusion, and retired, promising to omit no exertion to please at a more propitious day.

'The temperature during the performance may be assumed as near $17^{\circ}$ as possible. This would be warm if calm, but the breeze in the boxes made it cutting: nothing but the most determined loyalty rendered it endurable.

This gale came on with the thermometer at $20^{\circ}$. Onl the Sth it fell to $10^{\circ}$, at noon on the 9 th to zero, and rose as high at the Observatory, when we had it at $17^{\circ}$, in the theatre, to $20^{\circ}$, at least so I find it recorded. The tide-gauge rose one foot above its scale, and I have reason to believe that some morement of ice, umperceived by us, shook the Observatory.

On the 10th of November the gale continued with unabated violence, cutting off all communication with the shore, the temperatures ranging from $9^{\circ}$ to zero, rising according to the strength of the wind. A heavy snow-bank formed on our port side, but the reaction of the wind against our side caused it to maintain a respectable distance, channelling out a nice sheltered walk for our men in futme, and raising a most picturesque, ornamental snow-wrcath as a permanent overlanging wall, distant about sixty fect from the ship's side, and level with our upper works, or about fourtecn feet above the icc. Between us and the 'Pionecr' a huge wave of snow intervened, nearly on the upper level, and extended up to the shore, tapering to nothing. This weight of snow caused the water to flow up, whieh, when solidly 
frozen, formed a level promenade about six inehes above the iee. Thus from every evil some benefit results, if we be only disposed to view matters as boons of Providenee. The fissures in the iee, both in-shore and off into deep water, were also more numerous.

I have before noticed that this is not a snow-elad region,-that is, the land,- - and this morning has verified that observation. The gale has denuded the entire eoast, exeept in the ravines, where it is alnost perpetual, bridging over the watereourses, where, during thaws, the water flows with rapidity beneath.

To-day, the 14th of November, the gale abated. Yesterday the Master had been able to extrieate the elmronometer from the Observatory, and had I been aware of his intention wonld have prevented it. The opening the door to-day was attended with a kind of mysterious feeling, diffieult to deseribe; bnt a solemn, maeeountable oppression, similar to entering a long sealed tomb, weighed upon me, and yet there was literally nothing more than the dreariness attending the effeet produeed by any house overwhelmed by snow. 'The sensation was similar to the exploration of a eave, the work of ages. The seene before me was lowever one of Nature's immediate reeent aets. I must say that it afforded information, experienee, and matter for refleetion: what more ean I add?

'Thu seene before me was new, and, as eonneeted with my instruments, elarged with decp interest. In our external portieo the aneroid barometer, the wet and dry bulb thermometers, and some maximum thermometers were plaeed. Be it remembered that this was a portieo, 
composed of canvas, and the vibration eaused by the gale against the planking whiclı supported the instruments, might be supposed to militate against the formation of any fragile accumulation of impalpable "barber" or" snow dust; "barber" meaning truly, the immediate eondensation of the vapour arising from water at the point of eondensation, and blown upon the beard,-or the natural condensation on the bcard of the exudation from "the animal." I do not admit that the term is Arctic. I knew it-as all my old friends who preceded me some fifty years ago-as the well-known "barber" coming down the narrows of the basin at Halifax, Nova Scotia. Entering this portico, instead of the ancroid, a light eone presented itself, having the aneroid as its base, the base and frustum of the cone of snow bcing about two feet each. This, although of such light material, did not yield easily: but by the repcated application of the snow-brush I gradually eleared away the snow, and rescued the instruments unhurt.

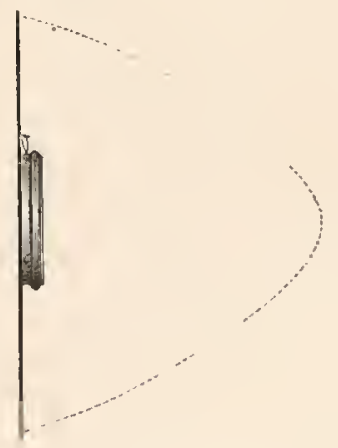

The next was the Observatory, and this I almost feared to enter, for the doorway presented difficulties 
whieh puzzled me. The standard barometer, previously coaxed into the performanee of its duty, was evidently damaged, and the snow prevented any foree being used to open the door. The mereurial eolumn had fallen below any rational range, and I was therefore prepared for the worst. On brushing off the snow I was satisfied that either the eoneussion of foreng the door (by Mr. Nobody), or the snow getting between it and the tube, had strained it near the eistern, a portion of the mereury eseaped, and it was rendered useless. Brusling the snow off each, I had to eongratulate myself, on quitting this elamber of lorrors, that I had lost but one instrument, and that was one in which I never had eonfidenee, for it lost mereury before leaving England. But the pressure of the gale had been so lieavy, that every possible ereviee, by whieh air eould enter, was beautifully fringed by deposits of impalpable snow-wreaths. These hints were not lost, and the proper remedies applied. 


\section{CHAPTER VII.}

Transit Telescope.-Extremes of Cold.-Effects of the Gale.-Remarks on Equipment.-Sensations of Cold.-Paraselena.-Schools Established.-Society of Loyal Aretic Engineers.-Deflections of the Magnetometer.-Experiments on Freezing.-Ice Crystals.The Aurora.

I HAD shortly before this eonstrueted a fixed transit teleseope, by fitting a good two-feet with the neeessary wires, and setting it, by our final observations, in the meridian. The results were dependent on the stability of the house, and of this now I had no further doubt. In few words, intelligible to most astronomers, I seleeted from Baily's Catalogue one of the prineipal stars whieh would, with others of a nearly similar deelination, pass the wires throughout the winter, so as conveniently to afford me times for five- or ten-day eomparisons, and thus verify my rates. Seleeting $13 \gamma$ Pegasi and $1970 a$ Hereulis as my standard stars, I possessed a range of seventeen hours to work upon until April, with all the intermediate stars, some of whieh happen to be more numerons than the Catalogue gives any notiee of, but whieh are of equal value, unkuown, for the mere purpose of rating ehronometers. 
On a decided ehange of temperature betwecn the 5th and 10th of November, I had firmly relied and expressed my opinion. On the 11th I did expect that gale, and I further expeeted a cessation of intense eold from that period until the 22nd December. This is not the result of a mere guess, but of a long course of observations in North Ameriea, and wherever eold predominates, that there are three periods of eold,- - one in November, ranging between the 5th and 10th; a second in Deeember, 22nd to 30th; and the third in March, near the 10th. These periods gcnerally exhibit the extremes of temperature. Of gales I take no special notice, but here they inevitably accompany any undue rise of temperature. These remarks led me to institute an inquiry, or construeting a table of eomparison of the temperatures cxperienced by Parry, Ross, and Austiu, to whieh will be added our own, and possibly those of the other ships composing this Expedition. I think that the seales will bear out my observation.

I notiee in Parry's Second Voyage, that he relatcs, "that the first week in the montl of November the weather was mild; the temperature then fell to $-30^{\circ}$, whieh change we felt sensibly." This extreme is not much exceeded by this month. His severity of midwinter eommences about the 26th of Deeembcr, continuing to the 9th of January, and reaehing about $-45^{\circ}$; on the 10 th it is $+4^{\circ}$, and eontimues - . 'Towards the end of February eold inereases, and up to the 11th of Mareh it is $-36.75^{\circ}$ : from this period (as elsewhere) intense cold eeases.

We have yet to record the result in this terra incog- 
nita, but I feel confident in the average result that the law will hold good, tides, winds, ete., takell fairly into accomt. To-day, 15th November, after inspecting the drift banks which seem to have their points of concentration bctween the stern of the 'Assistance' and the bow of the 'Pioneer,' I aseended the hill commanding the anchorage (Mount Bcaufort) to examine the effects of the late gale. It was now denuded, not a place on which to impress a footnark. And yet, some few days since, on this very ground, I had watehed the operation of entting "bricks" for building from this same spot, then a bank of solid snow preserving an average elear depth of one foot, and capable of bcaring my weight; the entire depth was about three feet. Some estimate therefore may be formed of the unecasing forec and scour of the wind and drift snow, from the perfect denudation of this peninsula, and indeed of all the visible outlines of the land. It required but one bright return of that absent sun to shed his rays on the landscape, and ideal spring would gladden our eyes. As I reached the summit I was yet more surprised: there the deinudation was complete; evcry opposing obstacle had been overcome, and I at least imagined that on the slope of the opposite declivity the common laws of Nature would be observed,- that a deposit would be found. Not a restige of snow remained, and if any difference existed, it was more denuded on that side, even to its very base.

It was amusing to observe its effects on all the line of supports, or snow pedestals, of the electrical wires. 'They originally stood complete, as at $a$, but were now reduced 
to the skeleton shown by $b$ in the diagram; other's were mere remmants.

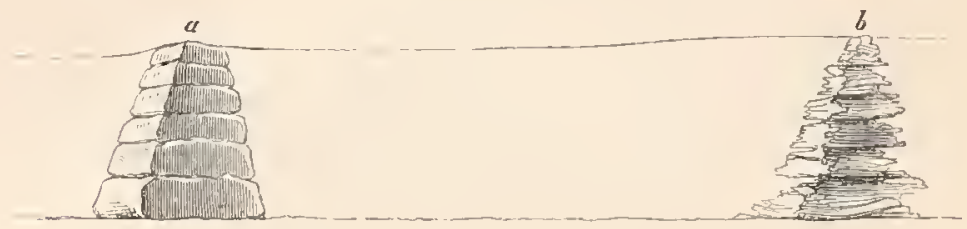

Abont this period I gave way-to the snow and gravel eovering on the deeks; not from convietion, but for peace and quictness. 'To Commander Richards I do not aseribe any such feeling of pressure; but he was evidently worked upon by constant dinning, elsewhere, into the belief that it was lis duty to urge me to satisfy this "former cruise mania ;" and if any fancied themselves warmer, the objeet was gained. The Sylvester would not act, and I very much regretted the absenee of Perkins' liot-water tubes, for those I knew how to eontrol-they were fitted in my own house, in the 'Terror,' and I could command their services up to any temperature. Knowledge is power; but no knowledge here could make Sylvester's apparatus work without an enormous consumption of fnel ; and let it be remembered, that in both these vessels it failed on the late Expedition. On the other hand, I know that with Perkins the diffieulty consists in moderating the heut. It is a matter beyond eontroversy, that if the initial heat is generated in Perkins, it must pursue its eourse throughout its eoil, and distribute its heat before it returns to the furnace; but Sylvester dis- 
1852.] THOUGITS ON EQUIPMENT FOR TRIVEL. 163

dains the cabin, or of reaching many feet of it, ncreltheless carefully conveying all offensive effluvia, tobacco smoke, etc. Not that I disagree with his principle, but that he camnot carry it out; he eannot, more than ourselves, demand that we should sail by the head, to give his current ascent. But the matter will be more thoronghly sifted (under very different arrangements) next winter.

November 25.- The increased thickness of the ice, and consequent grachal rise of the ship, prevents the tide-gauge from acting correctly, unless indeed the entirc frozen surface does not permit the due flow of tide. The difficulty, and incessant labour also, of breaking away the constantly-forming ice, is too much for the men; I have thcrefore put it out of gear until spring. Our attention is now principally directed towards the general equipment of the spring travelling partics, and we begin to find that these matters should have been eautiously considered in England, and not left simply to the mind of one, but of a board of officcrs. Indeed, I do not think that any part of the equipment comes properly within the province of a seaman; it is much more that of a ship-broker and the higher classes of tradesmen. The delay in appointing the officer who is to command-until too late to make much more than his orn equipment, and barely time to complete his ordinary dutics, independent of any preparation of scientific instruments-militates sadly against the interests of sueh an cxpedition. I can safely say that very few of the leading officers, inchuding nyself, were properly equipped, nor could wc learn, from any reliable channel, what was 
required. Every one lad his opinion, and kept it for his own use; we now know, and feel too, what is requisite. If time had permitted, I eould have had the opinions of the best praetieal men : lighter, better, and eheaper elothing would have been prepared for every individual, and submitted for approval; the tents would have been adequate to preserve life, if wreeked, and yet lighter for travelling; the stoves would have been serviceable now and hereafter; the sledges would not have been eonstrueted of soft Canada elm in the doekyards, but of lance-wood, by some intelligent earriage-builder, and shod with steel instead of soft iron: they would liave eost Govermment less money, and any North Ameriean knors well the value of lis polished rumner. Steel will pass over stone ensily, and not be bitten; iron is worse, eopper worse still, and lead, to the meanest capaeity, a dead drag. As regards the boots - these are now really so muel matter of general supply, from the days of Parry to the present, that it would be almost mutiny to disagree upon such a subjeet; yet they are far from waterproof, and for wet work, if properly made, they are indispensable.

But the "travelling boot" is of more importanceeverytling is at stake here. We are totally unprovided, simply beeause we trusted. "Who from faults is free?" We might, had the travellers of last eruise made known all that las now leaked out, and given us the result of their experienee, have been ready. for the field; we are at present totally unprepared, and with one shoemaker and some sailmakers elosely engaged making eanvas boots with leather soles: some lave been made of the 
seal-skins* obtained at Greenland, but that they will not last we can plainly see. They are like our scal-skin dresses provided in England, offensive even to talk about. 'Those purehased at Lievely have turned out better' : necessity there has tanght them the proper mode of culing the skins, and they are thim, light, and flexible. A preparation of Mackintosh and linen or silk externally, and fine, close, light cloth within, would have bcen infinitely preferable. Further, every article of elothing las been mis-supplied: nothing to fit, and therefore nothing comfortable: and not a tailor on board to alter! Of this the Government las always been kept in ignorance, and the routine has been perpetuated under the several commanders of these expeditions. The old prineiple, established in well-regulated ships about the year 1821, of allowing a certain number of contractors to fit the men, muster them before pay-day, and deposit their tieketed clothes mntil the First Licutenant saw they were paid for, and the duplicate taken for later distribution, could easily have been pursued here, and would lave afforder great satisfaction. I was mensured, it is true, but my clothes never were intended for a man under six feet, and plenty of room in arms and chest for very exter. sive smuggling. Fortunately, I did not reckon on the gratuitous supply, and obtained one warm ship suit; that for travelling I was lucky enough to obtain from the Governor at Lievely.

To myself all the blame is due, or rather to my want of opportmity or time to look after other even more inl-

* Thesc seal-skins were specially obtained for this purpose at Greenland, but were totally useless for such service. 
portant matters. Many expenditures of the publie money, I now perecive, might have been avoided, and space saved for much more important stores. From the proper departments at the Admiralty every facility was afforded, but many supplies would, if I again controlled a fittingout, be cntirely expunged.

How habit changes the feclings ! - not clothing, for I have not changed the ordinary suit which I donned on reaching the Orkneys, and even in travelling have merely added the Lievely seal-skin trousers. Not many wceks since, $20^{\circ}$ was considered very cold in our tents; and we werc reduced to melt snow to drink, about the lst of September. Another month,--about the 1st of October, I well recollect, being then in jeopardy, and the lcaders of this Expedition cut off for a time,-our anxions prayers were offered for a temperature of zero, or even $-10^{\circ}$, in order to freeze the sea intervening between us and the mainland, and cnable us to travel. Fren then we did not feel the cold. About the 16th of November I noticed apparent disappointment that the mercury had risen to $15^{\circ}$, and on the 17 th to $20.5^{\circ}$. One hero, in my mind's cye, appeared to repent of his coning to a rlimate where he was not to have "constant excreise and training" to aid lim in his preparation for his contemplated mareh in the spring, with a temperature at $-50^{\circ}$ ! but I very strongly suspect that my hero, if infolded, as the clown's baby was, would be found prepared for the worst,-sundry rolls of flannel to make the man.

For my own part, I feel the cold, at times acutely; it varies according to the state of health; but I fear it not, and must candidly express my wish to expcrience, in 
niy own person, provided as we are with sueh a perfeet set of instruments, the lowest temperature yet registered by reliable instruments and observers. I shall then be able to afford my humble opinion as to its effects. This is not foolhardiness, it is solely the pursuit of seienee; but I have no wish or intention to brave it by any unneessary exposure. I merely hope that the minimum temperature may not oeeur when I am in bed: I should be strongly inelined to defer its registry until I saw the minimum gauge in the morning.

November 30.-About this period the season beeones cxtremely monotonous, and one is reduced to all kinds of imaginary reasons to aeeomnt for the absenee of expeeted phenomena, more espeeially the aurora, for whieh every kind of solieitation had been adopted ; from masthead to mast-head of ship, as well as 'Pioneer'; thenee to the shore; up the hill; along the hill, on elevated poles; indeed, wherever it eould be supposed to pass, there a trap was in readiness. Possibly we had overdone the business, exhausted the atmosphere, and it had not wherewithal to support itself, or held aloof at least from combination with our proteeted neighbourhood.

The Crystal Palaee, eonstrueted as the sanctum sanctorum of the eleetrie operations, had shared the fate of such eastles,--liad proved too heavy for the floe, subsicled, water flowed in, and the gale of the 9th November had almost obliterated the site !

'This evening a beautifully defined paraselena was observed about north-north-east true. By measurement with sextant the interior eircle was found to have a raclius of $22^{\circ} 10^{\prime}$, vertieal as well as horizontal; the ex- 
tcrior $44^{\circ}$; the moon's altitude at the time about $30^{\circ}$. This beautiful phenomenon was represented by two concentric halos, incomplete near the horizon, accompanied by two strong crucial rays, vertical and horizontal, having the moon for their centre, the moon at this moment bcing four days past the full. It was also accompanied by arcs of other eccentric circles, having their common centre at a point within the zenith. The greater of these intersected the moon and outer halos, forming, at their contacts, luminous spots. So nearly did this represent the rectangular crucial form at the moon, that it was only by following the lower rays of the greater eccentric lialo that they could be traced to be really a segment of a great circlc. (See Plate.)

At the points of intersection of these halos, bright parasclenæ, forming five on the lower and two on the upper ares, presented themselves; the moon and the intersections by the vertical ray, exlibiting the most huminous. The second eccentric circle did not intersect, at any visible point, the onter halo; but where the outer ccccntric and vertical cut through the greater concentric, a sort of luminous ncbula appeared to vibrate, affording an impression of the effect of an aurora. I did not, at the time, consider that it could in any manncr lave any connection with the aurora or elcetric influence; but, on examining the magnetometer register, I found that between nine and midnight the instrument had becn deflected from $124^{\circ}$ to $134^{\circ}, 110^{\circ}$ to $125^{\circ}$ being the customary range when nothing is noticed likely to be of interest. In conscqucnce of the visits of very faint aurora, and other disturbances of the magnetometcr, fresh 



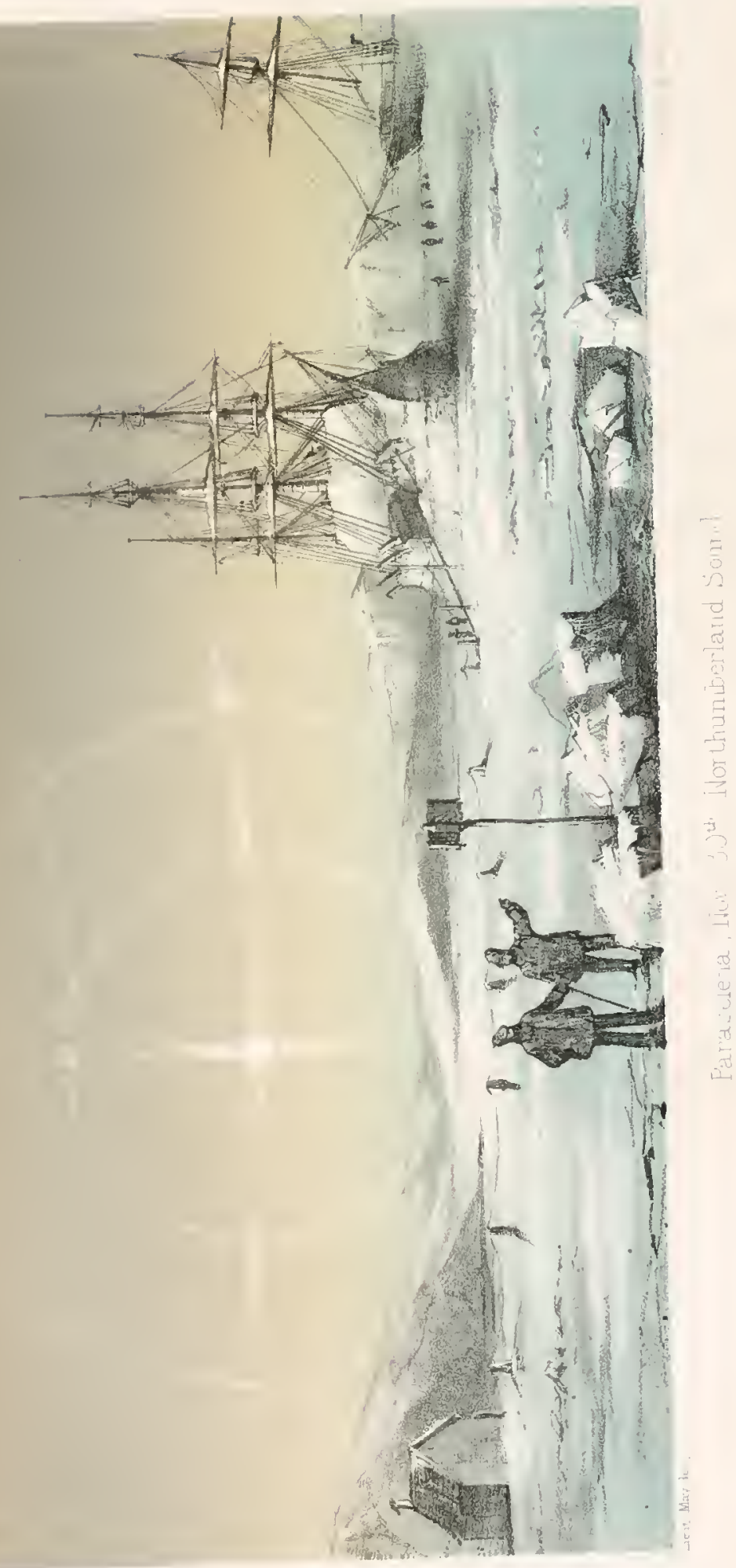


instructions were issued, "to note every deviation above or below 125." A similar phenomenon, but on a much redueed scale, and not ncarly so brilliant, occurred the night following. The magnctometer exhibited symptoms of undue disturbance between the hours of eight P.M. and thirteen (or one A.m.).

'To the peneil of Lientenant May I an indebted for' the very intcresting skctch of the subject under notice, as well as of the ship and teuder at our winter quarters.

On the forenoon of the 1st of Decenber the southcru arch of the horizon bccame considerably illuminated,-cqual indeed to our tints in lower latitudes beforc sumrise in March, and exhibited a very beantiful illustration of the effcet of intensc eold arresting the upper currents of air. This representation was so perfectly defined as to produee hard lines on the edges of the clouds, on which the faney would frequently trace ideal figures. In onc particular instance they secmed to be a eollcetion of

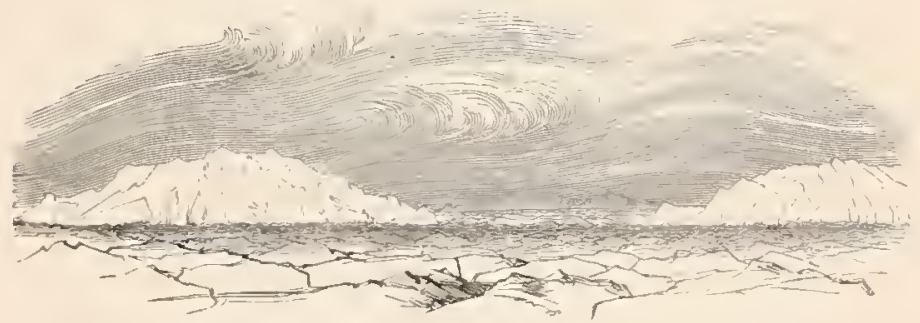

the various outlines of the summits of the land, and to be foreed into rounded forms, as if impelled by a furious gale.

Under this dark-eoloured sky the distant land on the 
southern slıre, near Cape Lady Franklin, * was peeuliarly refraeted, and appeared to be considerably nearer than our positive knowledge would warrant, displaying very beautifully its partieular features. A delieate salmon tint pervaded the horizon, affording the pleasing idea of a Marelı sumrise in England. Our elimate here, as far as we can judge from the journals of our predeeessors, differs eonsiderably from that further soutl.. It is drier, elearer,-I would almost add, superior,- to that we read of; but this, I imagine, results from a freer seope of air. On board I find the 'tween-deeks very wet and uneom. fortable, extending fiom the after-gumroom bulkhead to the bows. My eabin is partieularly dry, the ice in all the inacessible ereviees of the after-storeroom, abaft it, absorbing greedily the little moisture whiel may arise; all the bulkheads and furniture eracking and splitting with loud noise, at the same time attended with some difficulty in maintaining an even temperature. The wet between deeks, resulting from cooking, breatl, and drying elothes in the main loold, camnot by any present arrangement be remedied.

December 1.-Our first amusement was the theatre; this was followed by a newspaper; but something more uscful and solid was required. We therefore established the evening sehools, and not liaving sufficiently, or at all, prepared for this important matter by the eustomary Govermment supplies, the requisite paper of whieh to form writing-books dipped deeply into our supplies. Three classes were formed:- first, those who could read, wite, and ealeulate; seeond, those who eould read and write * The new Cape Lad! Franklin. 
only; third, those who knew nothing; and very satisfactory progress was made, thanks to the smpervision of Commander Riehards, Mr. Loney, and Mr. Lewis, who handsomely ofiered their serviees.

As there seened yet to be a vaenum, I proposed the ineorporation of the Loyal Circle of Arctic Engineers, to meet on Monday erenings, read sone interesting matter from standard works, or produee a paper upon particular matters immediately eomneeted with our operations, present or intended. My objeet was to enable the diffident seamen to stir themselves by a course of study whieh would cnable then to enter the 'Exeellent' with eertain acquirements. It is not the provinee of the Captain to take the lead in suel matters beyond the suggestion, and I expected, if the direetion eould once be brought to move in the right road, it might indnee those to think who ncver thought before, and perhaps seek to solve the menning of expressions to whieh they were not acensm tomed. It was a rational exereise of the mind, and mless some one set the maeline in aetion, the wheels night beeome so mueh clogged (by sleep) as to be inert when required.

There was another great object whieh I eonfess I had in view, and that was the disenssion, at the moment and on the spot, of many particular subjeets of great interest, and to stamp them by some mark of authority now, so as to prevent, at any later date, any thcorctieal fireside disenssions in England, where they might not be properly refuted. Opposition and disenssion here would seemre proper tests, wonld induee eaeh party interested to colleet faets; and thus our records would beeone valuable, 
and the minds of all better adapted to register, in fit terus, the fortheoming adventures of travel in a mamner befitting the importanee of this Expedition.

Finally, as regarded our little eommunity, it afforded amusement, ocenpation, and instruetion to the erew, all of whom were invited to produee papers upon any mat. ters they pleased. In order to facilitate this objeet, I drew up a set of subjects, on which papers would be invited, and endeavoured to include every eapacity, even to humorous matter's, for whielı eertain medals, "when engraved and struek," would be awarded. Having been elceted President,--indeed fearing that it might altogether fail if I did not start the vessel, I eommeneed proeeedings by delivering $m y$ address, and we contrived to eontimue our mectings during the winter, or truly to drag its lazy eoil along, until superseded by the preparations for sledge travel in spring.

"Notice is hereby given, that a Mceting of the Royal Society of Aretic Engineers will take place on Wontay Evening next, the 29th of November, 1852, in Main Hatciway SQuare, when an Original Taper, "On the Construction of "Lamp for the Cooking Apparatus of the Travelling Parties, to burn the fat of Animals slain in the Chase,' will be read by Mr. Halrmood, of the 'Pioneer.' The President in the Chair. The doors will open at 6.30 P.x. precisely.

"G. II. Richardos, Secretary.

"The Tempcrature to be preserved at $42^{\circ}$."

At the period of the spring tide in tlie early part of this month, a very extensive erack, following the eontour line of the peninsula beaeh, opened about half-way between the ship and the shore, eomputed to be in abont three fathoms, caused probably by the very great inere- 
ment of drift snow preventing the floating or eurvature of the iee at the eraek, where it appeared to be very thiek; it gaped about eighteen inehes above, but it was too elose below to admit of measurement.

On the evening of the 2nd of Deember, about nine P.M., the first well authentieated aurora was observed. All our instruments being then available, I was anxions to aseertain its effeet on them. Mr. Cheyne was direeted to report on the eleetrometers, and I add his remarks, as I believe he was ealled in time to see it in part.

"SIR,-Last night, at 9.20, I observed an Amrora : a light narrow streak extended from the summit of the Obscrvatory Hill, passing immediately through the zenith, in a direction south-by-east truc, terminating in a feather about $25^{\circ}$ north of the zenith (?). Four cumnlusshaped masses appeared as though only about a couple of hundred fect from the mast-heads; these masses lasted about three minutes, and then suddenly disappeared, having apparently shifted their position about twenty feet during that time; the long streak gradually vanished in about eight mimutes.

"The magnctomcter read $116.50^{\circ}$, was perfectly steady, nor was the electrometer in the least affected. The sky was perfectly clear.

"December 3, 1852."

$$
\text { " (Signed) J. P. Cherxe, Licutenant. }
$$

Mr. Cheyne was not an observer: he probably took this $116.50^{\circ}$ from the register for nime hours, ${ }^{*}$ whieh is there so reeorded, but he eould not judge of the steadiness of the magnetometer: at eight it was $117 \cdot 30^{\circ}$; at ten, $120 \cdot 60^{\circ}$. But it is not elear to my mind that it was not affeeted, and that the eauses whieh produeed this aurora had not been in aetion the last eight hours, viz. from four p.s. until midnight, when it reaehed

* All terms of time refer to astronomical periods from noon to noon. 
$137.80^{\circ}$, equal to $27 \cdot 60$ of defleetion, a disturbanee not before reeorded; even between nine and midnight we liave a defleetion of $21 \cdot 30^{\circ}$ !

The barometer, during the interval between eight and midnight, suddenly ehanged from $29 \cdot 860$ to $29 \cdot 650$, regaining its height, and rising to $29 \cdot 900$, when the magnetometer at sixteen hours showed $107 \cdot 90^{\circ}$.

I had almost begun to conjecture that we were in too eold a medium, or that it might not extend to so high a latitude. Considering, too, that its first appearanee generally oceurs with the first shades of winter, I could hardly understand its prolonged absence. I had observed it, to the north of Belning's Strait, on the 25th August and contimuously up to the 5th Oetober, in its greatest brilliancy; and in Wales, at Swansca, in August. But I notice that Parry, in his first voyage, and nearest to us, did not reeord it until the Sth of January; on lis third, which follows in order of latitude, in Oetober and November; and in his seeond, in Oetober. I did not witness it myself,-indeed it was not reporterl: I easually heard of it next day, and issued orders "invariably to eall me." It was only on perusing the offieial report called for from Lieutenant Cheyne, that I was indueed to seareh the magnetometer reeords for its motions.

December 5.-Another aurora, noticed this evening, presented vertical shoots or broom-like faseia, slooting towards the zenith (from behind the liill north-nortlywest), in pale flame-tinted rays, to an altitude of $20^{\circ}$. No disturbanee was recorded, but it is lighly probable that the variations registered at nine and ten r.M. are attributable to this influenee. It reeurred about midnight, 
but is not indicated by the magnetometer: at noon it is suddenly defleeted.

The bonei fide winter does not appear to eommence before the 1st of December, and about that period I observe that the walker's are more energetic in their exereise, and take to it more decidedly as essential to health than for amusement. I quite agree in this feeling, but deeming sundry wounds not easily cured, if I should unneecssarily exposc myself, or meet with an accident, fit matter's to be trifled with, am content to take that which the deck or light trips to the Observatory furnish.

On the 6th of Deccmber, being the last of our strolls, I noticed Venus to the south-sonth-west, refracted with extraordinary splendour; a complete Pharos, - a vertical ray exhibiting most splendid pencils of light. It was so well worth notice, that I called some of the officers ont to witness it; but I found that, on ascending the side of the hill to obtain a better view, it dwindled again into simply Venus; - not the first one she lias deceived.

A certain set of experiments were now made on freezing water; not simply to satisfy myself on this very beantiful phenomenon,-as all of Nature's works are when seientifieally investigated,--but for the purpose of determining the amount of vapour thrown off during the progress of crystallization. For these experiments I used a very delieate balance, substituting gutta-percha vessels of nine square inches' surface for those of brass; they were half an inch in depth. I found it diffienlt to deal with even one drop, but, by the aid of a very fine eapillary dropping (test) tube, and a shred of blotting-paper, soon adjusted ny balanee. The amount of water sub- 
mitted to experiment was six draehms, distilled; and as the perfeetion of the balanee eould not be carried on in an atmosphere of $-17 \cdot 5^{\circ}$, the preparatory measures were eondueted below. A kind of serecned eabin was ereeted on deek for experimental purposes; the temperature of the water below $=56^{\circ}$.

Time 0h. $26 \mathrm{~m}$., exposed to $-17^{\circ}$.

, $0 \mathrm{~h} .31 \mathrm{~m} .=5$ minutes, frozen, copions vapour.

"0h. $41 \mathrm{~m}$. = 15 minutes, hard, opaqne, and raised.

The loss of weight $=5.725$ grains, Left mtil noon following: no change. The same on salt water afforded 5.0 grains loss; frozen in 5 minutes, opaque in 7 minutes.

During the erystallization of the fresh water the effect was very beautiful:- - first, the smoky lambent vapour, and then the shadows of the first shooting of the erystals, whiel were cxhibited by a very powerful transmitted light, followed by the arborescenee, until sueeeeded by the clull glare of solidity, Even then I could scarcely fancy it frozen, until it eommenced the elhange to milkiness, and eventually, on rising in the eentre, beeame quite opaque. I am afraid I shall not eoax any of my fair readers to visit me, to partieipate in sueh experiments.

My next experiment was on a silk handkerchief,-I am not ashamed to say, belonging to one of the Banner ladics; it may yet be elaimed, and passed as an heirloom. This, being like its owner a delieate picee of workmanship, was well adapted to the purpose, as may be pereeived from the weight. Weighed beforehand, it appeared without fault, but it must go through the fire. Its first weight was 7 drachms 9 grains, but after sevcre drying, unfolding, airing, and redrying, it had lost 36.5 
grains; re-weighed beforc exposure on the lower deck$6 \frac{1}{2}$ drachms: in thrce lours it had absorbed 35 grains ; in five lours, 36 ,-given up 2 grains; after langing in my cabin twelve lours it had lost 8 grains. I fully intended subjecting this precious morcear to freczing proofs, but bad weather prevented this cruelty.

I do not think that any of the otlicr processes carried on at this period, cxcept the freczing of water in glass cylinders, are likely to interest others tlan those for whom they were expressly made, and which may possibly be placed in the Appendix.

Excepting Scorcsby, few, I believe, lave cnjoyed the study of the forms of ice-crystals. I have ever fclt deep interest in crystallography, as regards minerals, and mincral and other salts; therefore I could not but feel curious in watching the slow process of ficezing. A very clean glass cylinder, about a foot in length and one incli internal diametcr, filled with clear water at $50^{\circ}$, was submitted to a tempcrature of $-24^{\circ}$ : the vaponr continued to flow off for a considerable time after the water was frozen, and the icc had elongated itself out of the tube (which was very strong).

During the process of freczing (as we may oftcil obscrve in the crystallization of salts), I had the tubc placed in the focus of a strong reflecting carriage-lamp, and was thus able to trace, on a white ground behind, the beautiful regularity of its every motion, from the first silvery thread to the total condensation.

I noticed that the crystallization commeneed from below, and shooting its fcather-like processes, signalizing as it were (with its arms at $60^{\circ}$ above or $120^{\circ}$ bclow) to the

TOL, I. 
surface; it in return replied by similar signal, and interlaced its branches downward at the eentre. This was suceeeded by a milky infusion, similar to that of water introduced into a solution of camphor in aleohol, and all became ehaos. But I was not so easily satisfied; and repeating these experiments with salt water and at higher temperatures, I noticed that, as the point of general congelation approached, peculiar stars were produced, and rose to the surface, where they beeame attaclied to and formed the general mass. These stars were, I pereeived, perfect detached crystals, similar to those we meet with in the atmosphere, and which belong to bright-weather snow.

At a subsequent date, on sending for sea-water from a depth, so as to be free from ice, I noticed that it appeared impure, and rejeeted it; but the next bottle was, if possible, worse. This induced me to examine it closely. I then found that it was all composed of these fine crystalline stars, the water being, at the moment it entered my cabin, at the point of congclation. But in very few minutes after, being influeneed by a wamer temperature, its countenance ehanged, and beamed as bright as ever. Such we may obscrve constantly in port wine. I am afraid that many of us would under similar circumstances look very dull ; but I know, from sad experience, that my eountenance would undergo many very unseemly contortions under such treatment before it assumed anything like brightness: such would especially result from the pain of recovering from a bitc of Joln Frost, Esq.

On the 6th, 9th, and 10th of Deecmber, further cxhi- 
bitions of aurora oeeurred, and some slight defleetions of the magnetometer were apparent, but generally preceding or following.

About three A.M. on the 12 th, the aurora was reported by the officer of the wateh as very brilliant. But as I was comfortably in bed, and it was beyond nly examination and would vanish before I could possibly be in a proper state to receive such a delicate visitor, I direeted Messrs. May and Cheyne to pay every attention. It was Mr. May's guard at the magnetometer, and Mr. Cheyne was exeused wateh solely to attend to the eleetrometers, ete. It was asserted that the electrie fluid was noticed on the wires fairly canght; certes Mr. Cheyne found no disturbanee. I am not quite sure that he had his instruments placed in eonnection with his wires, or that he reached in time, possibly thinking as I did (?). Mr. May repaired to the Observatory, and unfortunately niy later order's were not then in foree, or we should have had a full history of this visitation. The magnetometer exhibited the most ummistakable signs of disturbance, moving instantaneously from $114^{\circ}$ to $1: 5^{\circ}$, and up to $150^{\circ}$, returning at four A.s. to $117 \cdot 90^{\circ}$.

This, then, I consider as strong proof; and taking into consideration other very deeided defleetions, when 110 eause was apparent, I am indueed to believe that the affeetion preedes or follows what may be indistinet, or not at all noticed by simple atmospherie observers, and nothing short of very close watehing at the magnetometer will indieate the trutl. But it must be borne in mind that this extra duty is a delicate scrvice, and, to maintain eren moderate interest, I know full well that the greatest 
tact is necessary to keep up the importance of the operators. No "soft sawder" will do here: it is only by making the observer feel his importance, and in this aspect his responsibility to the civilized world, that he ean be persuaded to extend his labours. Science will never be driven.

This aurora was reported "to have been duly captured, but broke the wires;" and as we could not find any of her (she has become a female) on the wires, and I could obtain no direet testimony (but the reverse) that Mr. Cheyne's elcctrometers were not influenced, the question remained in nubibus. 


\section{CHAPTER VHI.}

Short Days.-Minimum Temperatures. - Warmth of Tessels.-A SheBear.-Preparations for Travel.-Theatricals. - Shortest Day.Christmas Ode.-Christmas Fare.-Depth of Winter.- The New Tear-Comparison of Thermometers.-Freezing Mercury.-Range of Extreme Cold.-Freezing Ale--Alcohol at a low Temperature.

Ox the 10th of December our nights had bceome decidedly dark, and our small portion of day docs not fairly dawn on us until near eleven, when it is about as bright as a September morning in England, at fifteen minutes before daylight. At noon a delieate rosc-tint pervades the horizon to the sonth-east and south-west, where the land affords an horizon, permitting a very peculiar marked peneil line on distant objects. The land in our immediate neighbourhood exhibits just such a clear outline as the moon would produce if rising or passing at a slight elevation round the horizon; but notwithstanding the irregularities on the outline are so very distinct, I was surprised that I was unable to detect our substantial eains on the several points, so prominent but a week sinec : they did not exeeed three or five miles in distance, and doubtless would have been very apparent through the telescope. Such a distinetion, then, in tracing objeets, I 
consider to be the winter's warning. The weather has become steady and settled, and, guided by the reeords of previous navigators, I have made up my mind, after investigating the comparative tables furnished by them, that about $-40^{\circ}$, as a general temperature for winter, may be expected. I notice that the minimum temperatures for December of ' Hecla,' $1819,-43^{\circ}$; ' Enterprise,' $-56 \cdot 5^{\circ}$; 'Heela' (thind voyage), $-35^{\circ}$; 'Resolute,' 1850 , $-39 \cdot 5^{\circ}$; and as the general seasons in high latitudes may be said to observe some little uniformity, I have little doubt but we shall not differ, exeept it be by a few degrees lower in the scale, from our predecessors.

My opinion as to the cold dates I have aheady stated; but I hope to add to this Work tables cxhibiting the comparative ranges of temperature experienced during the several voyages of Captains Parry, James Ross, Austim, and the present, affording ten elear important columns, ranging over thirty-five years.

We find it very difficult to preserve a medium temperature between decks, the cold air rushing down and condensing the vapour so rapidly on the beams as to wet the hammoeks at night. Of this the men complain; but if we increase fuel and raise the temperature, it is even worse. 'The housing is old, weather-worm, and the same which was supplied to Captain Ommanney, with about forty yards to repair damages!

The fitting in these eases should be as perfect as that of the Houses of Parliament: there, it is matter of convenience, luxury, or personal comfort; here, the lives of many valuable men are at stake. A very simple original fitting, or the prepared materials supplied, would have 
rendercd these vesscls comfortable, at lenst habitable, even with an extcrnal temperature of $4.0^{\circ}$ below zero. It is now too late to commence working with iron tools; and in that temperature I should hesitate to ask, much more command, any out-door work ; but I do promise to remedy, if my ability permits, great part of these faults next scason. My plans are already formed, and have becn linted at wecks since. Looking simply to the temperaturc, I feel satisfied, so long as we can cnsure a moderate dry air, that iey surfaees, ready to absorb all the flying vapours, arc not injurious, - arc indeed safetyvalves; and my opinions are chicfly derived from actual obscrvation, principally on the habits of the Amerieans, Dutch, Russians, Danes, and Esquimaux. I camnot recall to mind any well-authenticated casc of wcakness, injured health, or diseasc amongst them, and yet they all pursue the hot dry air principle, rushing even into $\mathrm{cx}$ tremes.

The great cvil here is the grossly unscientific mode of entering our domiciles by our ehimneys, - in other words, by our hatchways; all other pcople civilized, and especially the uncivilized Esquimaux, cnter by the lower levels. Expericnce has taught them that cold descends, and will not run up an inclined plane if any break or rosistance is offered. The only mode of obviating this on shipboard is, unless an cntering or timber-port be cut in bow or stern, by producing such a labyrinth to the main entranee on deck, that the intervening atmosphere shall be warmed before it reaches the hatehway, and not permitted to act on the decks; further, that all objects interfering with the radiation of heat from the galley fire 
be removed; and finally, that the great escape shall be indueed by the column of warm ascending air above and surrounding the galley, or kitchen, of our ships.

December 16.-Any cliange is cheering, but in the present instance the excitement was beyond reason, and therefore sport was very soon spoiled. A she-bear and lier two eubs paid a visit to our dust-heap, on which, however, none of Goldner's preserves werc deposited; but they thought probably that they might derive some little advantage from licking the tins of Hogarth. Before any concerted aetion for the eapture of our visitors eould be formcd, some of our sportsmen, too eager to have their first shot at them, seared them off. As this was on the royal preserves, I issucd the requisite orders against poaching, determined that, at their next visit, fair play and no favour should be observed, and that an adequate force of dogs and men should attend the liunt. The poaehing for foxes also required looking into, and the several agents for the furriers, not in repute in this division of the Squadron, were warned to observe their respective bounds. Hardly had the first exeitement attending the visit of these boars ceased, when I learned that they had arrived from the quarter wherc our dogleader was excreising his animals with the sleigh, and as they possibly might liave done some mischief there, a party was equipped for the search. Warned by the sound of bugle and muskets, he soon made his appearance, and all again was quiet as a ship-of-war ean be!

'I'he cold begins to tell on all old wounds, frost-bites, etc., raising mplensant sensations; and, possibly from nervous affection, rendering a twinge (at any other pe- 
liod umnotieed) importunate; nevertheless no one seems to fail in health, indeed the offieers and erew will probably be in mueh better eondition on the 25th Deeembel', 1852 , than they were on that day last year! 'Their' light hearts, no doubt, will be far away.

In the monotony of winter it is well that we ean find employment; all our attention is now direeted towards the intended spring travelling, and the arrangement of men, as well as aides, to the several sledge duties. As regards myself, upon this latter point, I shall not deeide until the last moment, meertain whether I may not be plaeed beyond the pale of sueh exertion. I do not fear it; but I have many eroakers about me, who faney I ought not to venture. With referenee to the duty to be exeeuted, I am aware that it will be a very scrious and doubtful service, for I know full well the uneertainty of the iee with whieh we shall have to deal and the diffieulties men and offiecrs will have to eneounter, should they be eompelled to work with boat and sledge together, which, from a eurious habit of "seeing ahead," I am inelined to think will be imperative; or, should they sueeed in getting safely across to the southern side of this ehannel on firm iee, still boats will be requisite for their relief, unless indeed the water makes early and permits the ship or tender to visit the sonthern eoast, whieh I an inelined to think will not be improbable.* As to the north-castcrn seareh, whieh I lave selected as my own route, I have no fcars, beeause, as I shall lave to visit islands where the open sea prevailed last year, at an early period, I shall be provided with one or more boats, duly prepared; and, if eanght on the mainland, I am 
now suffieiently acquainted with the leading southern features to know where to cut through to regain the ships.

The lady bear and her eubs paid another very short visit, but, alarmed by the slanming of a door, made off to the soutli-rest.

On the 21st, our shortest or no day, the seamen of the 'Pioneer' and 'Assistanee' performed 'Hamlet' and the 'Seapegrace.' The performanee was, as far as we could hear, good: but some doubt as to the scenery,- the preponderance of elouds at three fcet above the stage, resulting from the condensation of the breatl of the andience, rendering the busts of the actors barely visible, and thus, at all events, adding to their eonfidenee, as no blush could be detected.

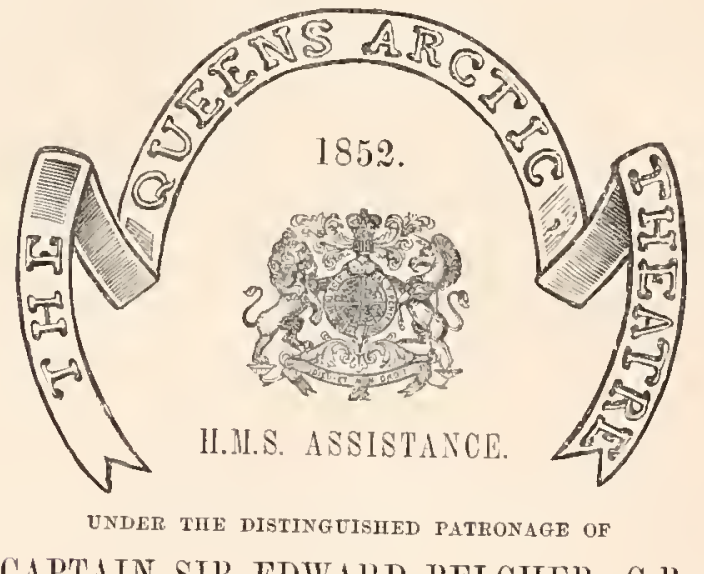

CAPTAIN SIR EDWARD BELCIIER, C.l.

Commander G. H. Ricmands, the Manager (and now Sole Proprietor) of the Qucen's Aretic Theatre, has the satisfaction of acquainting the Nobility and Gentry of North Comwall and the neighbouring county of Northumberland that he has just arrived from the very POLE itsclf, accompanied by a CORI'S DRAMATTQTE never equalled in this or 
any other conntry. He also brings with him a choice selection of Scenery, only to be procured in that delightfnl and highly favoured country; and, with a view to the revival of the legitimate Drama, and a desire (he trusts a laudable one) to render, if possible,

\section{THE SIIORTEST DAY STILL SIIORTER!}

has determined to open his house on the Twenty-first of December, for the performance of the first Act of the Tragedy of

II $\triangle$ II L T T, BY THE 'PIONEER' TRAGEDIANS.

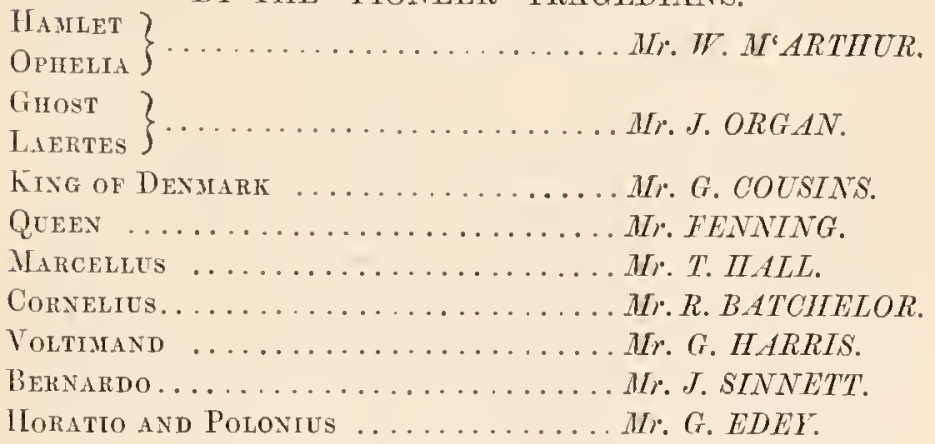

Dnning the Interlude the Andience will be entertained in a variety of ways, including:

SONGS BY MESSRS. 11. JONES AND C. FIELDER, and a highly pathetic Story of Negro Love by Mr. J. REID, in fidl

Negro Costume, as being peculiarly adapted to this climate.

After which will be performed the much-admired Comedy of

THE SCAPEGRACE, BY THE 'ASSISTANCE' COMPANY.

Colonel Aubrey . ................ J. REID.

Peroquet . . . . . . . . . . . . . . MI. J. BARNES.

Mrs. Aubret..................... Th. BOND.

Charles Daklington ................. ANGLETON.

Bustue .................... NACARTNEY.

Tucher . . . . . . . . . . BRIANT.

The Nanager's Own Band will be in attendance, and he has determiued to introduce an entirely new feature into his Theatre on this 
occasion. Having, during his recent travels, observed the highly elastic properties of ice, he has, without hesitation, decided to construct his stage entircly of that material, and he trusts that no misconstruction (such as scarcity of deal boards) may arise from an act certainly original) and based on scientific principles.

The Manager and Sole Proprietor also takes this opportunity of offering his acknowledgments to the Public for the very liberal support he has already received at their hands, and ventures at the same time to remind his firiends (for such he must always consider the Pnblic) that for the consummation of his fondest hopes, (viz. the realization of a moderate competency wherewith to retire into private life, he still looks to them; and, relying on a discerning people and conscious of his own deserts, he will not desert the stage while a plank of it remains.

The IIouse will open at 6.30, the Performance commencing precisely at 7 o'clock.

Tickets may be had of H. BRIANT, at the Aretic Printing Office, Winter Quarters, Northumberland Sound.

N.B.-The business of the Printing Office is considerably retarded, in consequence of the ink freezing on the rollers.-Printer's Devit.

BY AUTILORITY.]

[11. Brimt, l'rinter.

Commander Richards, the indefatigable Proprietor of Her Majesty's Theatre Royal, supported the establishment and his eharaeter with his aceustomed spirit and effeet, and was most rapturously and warmly applauded, particularly at the customary royal message, but this time varied to home-brewed Allsopp. That name will live for' ages in the recollection of all Polars.

Sir Edward Parry mentions that the zeal of his manager produced representations even when the thermometer fell below zero. In the present instance the temperature was $-34^{\circ}$ outside, but the after-deck thermometer is registered as low as $-37^{\circ}$. It was, however, to my feelings, uneomfortably cold, even in Mer Majesty's box.

Great dissatisfaction appeared to prevail at some portion of the speech of the now Proprictor, intimating an 
intention of going to Melville Island or the 'North Star,' even to Behring's Strait or the Sandwich Islands, from whence most liberal offers had been forwarded. Nothing: short of the blackest ingratitude and treachery could induce such a step: the curtain fell in rapour!

Thus we passed the Rubicon of this much talkedof polar winter in Northumberland Sound, the evening terminating at a supper given on board the 'Pioneer," whcre "bright eyes" as well as "Brother Polars" werc not forgottell.

Scarccly have wc breathing time, at this busy season, to dispel the anusing matters yet floating before our eyes, erc some otlier cqually great, or greater, cvent demands our attcntion. Surely our good friends in England must be now pitying the poor unfortmatc Polars, deprived of the light of that cheering and health-supporting lnminary, which glaringly but too often reminds them of somc gap in their circle, as well as dwelling on the horrid cold of that inclement, boisterous north, and dreaming of bears, wolves, and starvation!

Wait a few moments: Christmas approaches, and less noise and confusion perhaps prevails, - -all are intent on some great object; mighty preparation is going forward, of which the principal, as at home, is kept in profound ignorance: enough that he knows when he secs the bill of fare, and "pays the pipcr."

December 25.--At midnight certain sounds of music, not customary, werc noticed near my cabin door, and permission to cnter having bcen granted, a demi-official note was presented (from the uniform I should imagine from the Court of Louis Napolcon). This was, I eventually found, a Christmas Ode, followed by the same very 
well sung; and, with the best wishes of a merry Christmas, the deputation withdrew.

a Christifas piect.

Awake! awake! the Old Year's going,

Time flies apaee;

Awake! awake! the New Year 's eoming,

To take the old one's plaee.

Arise, arise, good shipmates all,

And do not danger fear;

Arise, arise, good shipmates all,

To weleome the New Year.

God bless our brave old Commodore,

And our good Commander too:

Not forgetting all our Officers,

And our true and gallant erew !

Sleep on agrain, and on your brows

May soft repose be seen!

Sleep on again, while in our lay

We'll sing, God bless the Queen!

H.M.S. Assistance.

Wishing Sir Edward Belcher, C.B., a happy and prosperous New Year.

Composed, I believe, by the Printer or his Devil.

Shortly after prayers I was officially informed by the Commander of the 'Pioncer' that the State Sledge, driven by the Queen's coaehman, in full mniform (beadle of the parish), was in waiting, the Union flying instcad of the footmen at the stern. Althongh such a pageant, perhaps, to those who know me well, was not quite in aecordanee with my taste, still I had some part in the Play to perform, and knew too well the chords of Jack's lıumours to fail in their gratification; they were most gracionsly appreciated. Mounting the state carriage, twelve of Her Majesty's best breed of Polars convcycd me along- 
side the 'Pioneer :' every precaution had been adopted to prevent my wetting my feet; temperature, $-36^{\circ}$.

Rather pantomimie the ehange! Stepping on her decks I was metamorphosed, in less time than Harlequin's wand eould effeet it, into my proper self, reeeived and returned the salutes, inspeeted the men, and sent them below. Still adhering to my proper character, I inspected their preparations for their Christmas dinners, fancy decorations, etc., all of which were marked by neatness and extreme comfort, the entire midship division of the ressel being, in winter, appropriated to the crew, more eapacious and higher in comparison than the 'Assistance.' I had here an opportunity of witnessing the superiority of Arnott's stove over the Sylvester', with less expenditure of fuel.

On the presentation of wine by the leading petty offieer, I addressed a few words to them, expressive of my satisfaction, and reminding them that the roast becf then smoking before them was "Her Majesty's own," request. ed that due honour should be aecorded to the liealth of "Her Most Gracious Majesty Victoria, God bless her! and all the Royal Family." This over, I gave the health of "The 'Pioneers,' and may their enjoyment never be less than this Christmias!"

I now returned, to preside, at noon, over the opening festival of my own erew. Here too I found all the luxuries, not forgetting roast beef and plum-puddings. The arrangements were all perfeet, and in good taste, and our trusty crew were prepared to do justice to their fare, and cnjoy themselves. I felt differently here: why, I know not. I felt it a more solenm aet. These were my own immediate crew, and I felt a deep interest in 
them all. They were yet without fault. I eould not help telling them so, and expressing my earnest hope that they would return as we eame out (a maiden slip?). Aeepting the proffered glass, still of the Queen's own good port, I gave them the similar toast of "Our Queen, God bless her!" Never did a more hearty peal, nor from heartier lungs and more loyal hearts, ever try to burst those deeks. My next duty to my Sovereign being that to my own family, I gave them "A merry Christmas, and may God bless you all!" Taking advantage of the fog, I retreated to my eabin, possibly not missed, but the eheers probably eontimued until they diseovered that they were alone in their glory. It has never been my lot before to witness more apparent enjoyment than seemed to pervade the Northern Division : nothing followed to shake that good opinion.

About six the offieers of both vessels, numbering seventeen, dimed with me, and I think, by the very kind forethought of several warm-hearted fair friends, who will possibly remember their good deeds with satisfaetion, that my table groaned under as goodly a spread of the luxuries usually exhibited at this season as it eould have done in Merry England, not omitting the roast beef, plum-pudding, minee-pies, and frosted eake of our national predileetions. "Poor Polars, how I pitied them !" Yet they seemed to enjoy themselves, and even to think of those poor people in England who mingt not enjoy themselves with half the genuine feeling. Our Queen and Consort, our Duke of Cornwall, our relations and friends there, were not forgotten, not even the banner cherubs and their nlottoes; nor were our eompanions here, though for a time severed, yet possibly to be for a 
monent reunited in our spring travels, omitted. The toast, "The rendezvous, $77^{\circ} \mathrm{N}$, $105^{\circ} \mathrm{W}$.," was emphati. cally given and determined on, as if it was already cngraven on the chart. About 1.30 each retired, to dream of home.

Many uninterested persons may doubtless be of opinion that these are not matters for the public journal of thc Commander of such an expedition. I am willing to risk the verdict; it is the true index of the habits and custons of the Aretic cxplorers in 1852-3-4-5-6, etc. Many an anxious eye nay be turned to these particular pages, when others of dry matter, or of a controversial complexion, would studiously be avoided. We have but little sun at this season. Let us enjoy all the brightness that warm hearts and innocent amusements can afford, not forgetting those whose fcelings are also gratified at learning that in all our enjoyments their presence alone was wanting to complete the eup. Sailors ever had, and will, so long as the good old breed is not extinct, have their feelings deep as the clcment they swim on, and no disguise.

December 26.-All quiet; great disposition to slcep, in which they were allowed to indulge until the time for prayers, put off today until eleven. 'To many a Commander this is the most anxious day. 'Thankful did I feel that all had gone well,-not a whisper of any defect. "Wliat would I not give to wander?"-however, I fecl assured that we were not forgotten; so my dreams, at least, assured. Where will our next winter be passed? was more than once started, - a most difficult problem to contemplate: time alone can tell! 
December 28.-Spring tide of this moon, and yet we have the thermometer down only to $-40 \cdot 7^{\circ}$; mereury partially, not entirely, frozen. How one's feelings appear to aeeommodate themselves to the changes! It is ealm, and therefore we feel it less. I lave just returned from taking exercise on the floe, but without being sensible of any inconvenience; and it often occurs to me that it is injuclieious to make so much parade about temperatures, when, were it not for the thermometers, few would fecl the variation. On the other hand, the knowledge gives a man assurance of what he can bear, and furnishes him with a Mentor which prevents his exposure to undue cold without being prepared to meet it. It is curious, to the uninitiated, to view the Esquimaux dogs perfectly satisfied and luxuriating in the snow at this temperature! They have snow-houses, into whieh they can retire, if eold pinehes; but we do not perceive that they do so until the breeze makes it felt, and then the tempcrature rises witl the force of the breeze. When the wind blows strong, with drift, the poor animals lowl and move about evidently uncomfortable; hunger and frozen food may in part aecount for this, but why are they never frost-bitten?

One very curious fact, which I have repeatedly noticed, and to which I never have observed any previous allusion, is the falling of light bodies during intense cold, and, of course, calm weather. Does intense eold produce anything to be eompared, direetly or indirectly, to a vacuum? Vapour condenses and falls perpendicularly as fine crystalline ice; all objects exposed to this vertieal aetion become covered with rime, but never laterally. The 
very eurious question l'esults,--from whenee does our snow, or crystalline stars of ice, eome? They must be formed and preeipitated from an atmosphere exeeeding $32^{\circ}$ in temperature: they deseend into $-42^{\circ}$; no less than $74^{\circ}$ variation in temperature. Does the eold mediun then eompel all warmer bodies (possibly by condensing their vapour on them) to fall as the feather under the reeeiver of an air-pump? Verily we hourly witness strange things, and but too often how many pass disregarded, umotieed, beeause others have preeeded! Sueh will ever be the ease where seienee is at a diseount, or the possibly ignorant self-eonstituted philosopher sneers at the questions whieh he is unable to answer, or whieh happen to interfere with a favoured or popular theory.

\section{'The New Year of 1853.}

January 1.-This morning was ushered in by a song, eomposed by our own bard, and sung by the ehoral band of 'Assistance:' a eopy was delivered to me, but being in bed, much tired, and suffering from a fall on the iee, I eould not enjoy its intent. The erew however are enjoying themselves; so far all right.

Today our gun-room offieers entertained their friends. It passed off mueh in the same style as Christmas, Commander Riehards presiding. I was of eomrse a guest, and happy to eontribute to the general good humour. We only wanted the missing parts of our Squadron, to make all eomplete. Shall we be able to pass it together next year? My own impression is adverse : if we should meet before, undoubtedly our winter stations must be asunder. 
January 6.-Our temperatures seem now inelined to reaeh their lowest point. It is at present $-51.5^{\circ}$, and falling; yet we do not feel the ehange. In some of the journals we may possibly find a minimum temperature nearly $2^{\circ}$ below the standard, but the final results reeorded in the Meteorologieal Journal will alone be eorreet. The annexed eomparison of the seven best will indieate pretty elearly the value of the instruments:-

\begin{tabular}{|c|c|c|c|c|c|c|c|}
\hline Standard. & 2 & 6 & 8 & 20 & 3 & 4 & 5 \\
\hline$-20^{\circ}$ & $21 \cdot 0^{\circ}$ & $20 \cdot 0^{\circ}$ & $20 \cdot 6^{\circ}$ & $21 \cdot 2^{\circ}$ & $20 \cdot 4^{\circ}$ & $20 \cdot 7^{\circ}$ & $21 \cdot 1^{\circ}$ \\
-30 & $31 \cdot 0$ & $30 \cdot 0$ & $30 \cdot 0$ & $31 \cdot 5$ & $30 \cdot 8$ & $31 \cdot 2$ & $31 \cdot 5$ \\
-40 & 40.5 & $39 \cdot 6$ & $39 \cdot 8$ & $40 \cdot 5$ & 40.5 & $39 \cdot 5$ & $41 \cdot 3$ \\
-50 & $50 \cdot 0$ & $49 \cdot 0$ & $49 \cdot 0$ & $51 \cdot 5$ & $49 \cdot 0$ & $49 \cdot 3$ & $51 \cdot 9$ \\
\hline
\end{tabular}

Cold as this is,-and my eabin temperature fell to $22^{\circ}$, freezing everything in it (malgré Sylvester),--the eold, as intensity, would not have been noted, unless the offieers at the Observatory lad given information.

Last night heavy sounds were heard, and some as. serted that the reports of gims were distinguished; but I suspeet that it was merely the result of a distant floeeraek, as the temperature of the ship enusing her to release herself from the iee, or from portions langing on her, frequently produees similar results. The light is visibly inereasing, enabling me, near noon, to note time easily by a wateh.

January 7.-The noises were repeated last night, and a large additional eraek between the ship and the $\mathrm{Ob}$ servatory was noticed. I understand that the 'P'ioncer' 
also shifted her bed. The great masses of snow on the ice, hourly consolidating from evaporation from beneath, probably press the floe downwards, and produee these very sharp somds, very similar to the snapping of heary bolts of iron. The prevailing impression, I believe, is that it arises from the latter cause. However, this is not satisfactory: no bolt or cliannel plate, exposed, has been known to part; and if all these sounds proceded from such eanses, I fear there would be none left to trust to, next sumner.

The mercurial thermometers laving indieated temperatures much below the freczing-point of mercury, and this affording an opportunity of examining this metal but seldom presented to quiet and careful research, I determined to avail myself of it. 240 grains were weighed in my eabin, contained in a fine porcelain moltar; the mortar and mereury having been previously subjected to a continued lieat on my stove, to expel any possible moisture. 'The mercury was pure, being part of that which eseaped from the standard barometer on my cabin sofa, and carefully preserved in a stoppered phial for such experiments. (Temperature $40^{\circ}$.) It was then carefully removed to the thermometer-honse, and the balance found eorrect. Exposed for twenty minutes to a temperature of $-47 \cdot 7^{\circ}$ the mereury began to crystallize: the eireumference became very convex at its elges of contact with the conical vessel in which it was contained, and the centre raised to a point when it had aetually congealed; it lost 1.5 grains. At the first fifteen minutes' exposure, the scale in whieh the mereury was contained rose very perceptibly as it diminished in 
weight; it then reeovered itself; and finally, on being re-weighed in my eabin, was deficient 1.75 grains.

In order to determine its effect on water, I turned the frozen mass into a tumbler of water containing six fluid ounees at $47 \cdot 5^{\circ}$ : the mereury simply beeamc encased in ice, and when it at length flowed on the bottom, the temperature indicated $44.5^{\circ}$, a difference only of $3^{\circ}$. I was anxious to determine the form of its erystal: this was a very diffieult matter. It was attended with great ineonvenience in the open air, and the ehange was sereened by the supcrficial crust forming before the body beeame solidified. The transition from the solid to fluid eould be better watehed : this I tried. It then oeenrred to me that by using a large open-mouthed jar, containing half a gallon of spirit of wine or alcohol eooled down to $-4.7 \cdot 5^{\circ}$, that I eould leisurcly, in my eabin (aided only by candle-light), watch its motions, and freeze or liquefy at pleasure. In this I succeeded,-remarking however that several travelling mercurial and other thermomcters presumed to read below $42^{\circ}$ ! But to the result of my examination: previous to freezing, or at the instant of returning to fluidity, I noticed that the mercury assumed a very aetive motion, resembling living polypi,-parts moving in circles with great velocity. Positive erystallization I could not detect, but the inelination appeared to be nearcr to the forms of lead or bismuth on cooling, the surface lines being clearly reetangular, or a beautiful network. This was on the semifluid; $m$ its dense form nothing eould be traced. Although mueh exposed today to low temperature, no change in my ordinary cabin dress was found requisite, 
1S53.] LOW temperatures, Not SENSIBLy FELT. 199 although oceasionally I inquired if my nose exhibited any symptoms of the whiteness attending frost-bite. The dogs were more than usually playful, and fond of being earessed; once I thought that they would have been glad of my seal-skin mits by way of lunchcon. However generous one might be at another time, the present temperature rendered it inconvenient.

Jamuary 6.-This evening the 'Pioneer's' party furnished their quota of amusement, as may be learned from the following programme:-

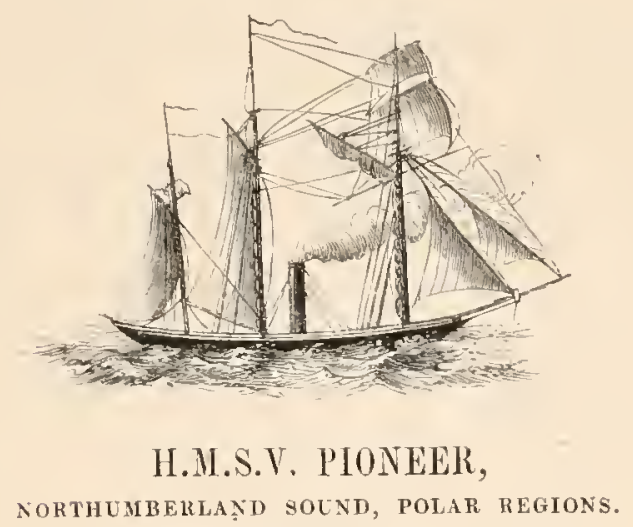

LIEUT. SHERARD OSBORN has the honour to annomce to the Polar Publie in partieular, and the World at large, that

\section{THE QUEEN'S ARCTIC PHILHARMONIC SOCIETY}

will hold its General Anmual Meeting on Thursday evening, the 6th of January, under the immediate patronage of

CAPTAIN SIR EDWARD BELCHER, C.B.

AND THE OFFICERS AND SIIP'S COMPANY OF

H.M.S. ASSISTANCE.

Then the distinguished members of that Soeiety, as well as other local Musieal Celebrities, will take prominent parts. 
The Evening's Entertainmont will commenee with the full Band playing, muler the leadership of our

$$
\text { Polar Costa-IIERR IIAR I OOD, }
$$

A GRAND FANTASIA, altered from Comt IInm's Les Articux à Bouf et Bière.

PART I.

Sentimental Section, Ied by the Primo Tenore, SIGYOR ALLARD (Perp. Grand.) will execnte rarious select Solos; and Duets by $\mathrm{Mr}$. W. HOOD, S.C., SIGNORI SINNETT and CUSTANCE, all Members of the Q.A.P.S. Followed by

$$
\text { UN PAS MELE-by Moxsieur C. ALLEN. }
$$

The Comic Section, under the able baton of Professore DON JUAN RICARDO, will consist of an elegant selection of Melodies by DONS JOHN and RICHARD IHALS, DON BENJAMNN YOUNG, and DON GEORGE COUSINS, a galaxy of Buffo Singers unequalled in these Regions.

\section{PART II.}

La Talse des Baleines and Narwhal Polka! by the Band. Followed by a Grand Terpsiehorean Interlude, by Messi's. Dickess, BarcineLoR, and AlLeN.

The Serio-Comic Seetion, led by that well-known Basso HERR IIORATIO IIEBB, and exhibiting such names as

HERR ORGIN, HERR EDET, AND HERR DICKENS!

will assuredly fulfil the most sanguine cxpectation of lovers of the Anglo-saxon School.

The Curtain will drop to the Glorious Strains of

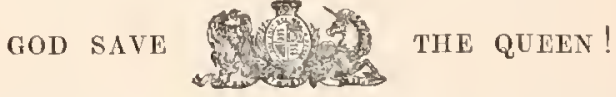

The Proprietor need hardly remind the Publie, that having secured them a Musical Feast, in which the whole Talent of the North will be concentrated, that Ier Majesty's Theatre and the Italian Opera are entirely done up, and the Sole Lessee and Hanager is supposed to have absconded with his Seenery and Elastic Stage! to Beechey Island, to divert the Depôt.

The general arrangements of Scats, Lights, and Refreshments, hare been placed under the catership of $\mathrm{Mr}$. Jos. Organ, and Mrs. Feming has engaged to supply lces gratis.

BY AUTHOHTY.]

[II. Briant, Printer. 
This amusement, remarkably well got up, eonsisted of a selection of very good songs; and what rendered them to many the more interesting, particularly to the officer part of the audienee, was their almost perfeet originality.

The lower deck of the 'Pioncer,' warmed by Arnott's stove, dry, and much more eomfortable than my eabin, aeeommodated both erews, mustering about eighty-six. The entertainment elosed with the National Anthem. The temperature has not risen above $-46^{\circ}$ the last four days, exhibiting a mean temperature for the interval of $-53 \cdot 20^{\circ}$, or $-55 \cdot 61^{\circ}$ for threc days.

January 15. -The following may prove interesting to inquirers after the extreme cold of our position.

I observe, in that exeellent work of Sir Henry De la Beche (on Geology), that M. Arago asserts, "that in no part of the earth, and in no scason, will a thermometer raised two or three metres above the ground, and protected from all reverberation, attain the 46th Centigrade degree." Seeondly, "In the open air, the temperature of the air, whatever be the place or season, never attains the 31 st Centigrade degree." Thirdly, "The grentest degree of cold which has been observed upon our globe with the thermometer suspended in air, is 50 Centigrade degrees below zero." Fourthly, "The tempcrature of the water of the sca, in no latitucle and in no season, rises above 30 Centigrade degrees." We have been informed that Sir James Ross registered the air at $-60^{\circ}$; of this however I have not at present any direet eridenee. As to any question arising to affeet the registry of our instruments, there ean be no possible 
doubt. The observers have been too numerous to allow of mistake: the self-acting index tells its own tale, adverse observers wateh every decimal division, and the lowest minimum thermometer, after severe invcstigation, has been rejected. I eopy the following from the Meteorologieal Journal:-"January 12.-Aloout nine this evening, being at dimner witl my weekly party of officers, I was informed that the temperature had fallen below $-62^{\circ}$. As this was a question not to be casually passed over, I visited the Observatory, and remained walking about in my simple cabin dress for some time; $-62 \cdot 5^{\circ}$ was the lowest whieh $I$, as well as others, read at the standard. But the minimum thermometer indiees, read next day at eight A.M., only gave $-62 \cdot 0^{\circ},-61 \cdot 6^{\circ}$, $-66.0^{\circ},-63.2^{\circ}$. The night was bright and ealm: no sensation of eold. $-63 \cdot 2^{\circ}$ is the external exposed thermometer, but was never read, excepting by its index, at that graduation. This external thermometer, after severe testing under the boat as low as $-40^{\circ}$, with the entire range of spirit and mercury thermometers, was selected as the standard Observatory gauge: supported on an open frame, attached to two pikes about one foot asumder, it was subjected, uneovered, to all the winds of heaven. That was read at $-6255^{\circ}$, and indieated what I have rejected, $-63 \cdot 2^{\circ}$.

Jamuary 15.-I was induced, whilst writing these remarks, to turn to Parry's work, page 145 (first voyage, 1819-20). On the 15th of February lie remarks as his coldest, the thermometer standing at $-54^{\circ}$ for fifteen hours and a half, but his maximum on that day was up to $-32^{\circ}$. Looking over the Observatory reeord, I no- 
tice that the following indieations of low continuous temperatures prevail :-

$-46^{\circ}$ and bclow, 156 continuous hours.

$\begin{array}{lllll}-50 & , & 89 & , & " \\ -52 & " & 88 & , & , \\ -55 & " & 52 & , & ", \\ -58 \text { to } 62 \cdot 5^{\circ} & 14 & , & ",\end{array}$

As the tabular register may never meet the eye of the casual reader, I will here insert eleven cold days in January, from the 5 th to 15 th inclusive :-

\begin{tabular}{|c|c|c|c|}
\hline & Maximum. & Minimum. & $\begin{array}{l}\text { Mean, } \\
24 \text { readings. }\end{array}$ \\
\hline January 5 & $42 \cdot 5^{\circ}$ & $48 \cdot 0^{\circ}$ & $45 \cdot 08^{\circ}$ \\
\hline " 6 & $47 \cdot 0$ & $51 \cdot 5$ & $49 \cdot 02$ \\
\hline , 7 & $37 \cdot 0$ & $49 \cdot 3$ & $38 \cdot 01$ \\
\hline , 8 & $39 \cdot 0$ & $47 \cdot 5$ & $43 \cdot 00$ \\
\hline , $\quad$ & $46 \cdot 5$ & $50 \cdot 0$ & $47 \cdot 97$ \\
\hline, 10 & $49 \cdot 5$ & $56 \cdot 0$ & $54 \cdot 17$ \\
\hline , 11 & $50 \cdot 5$ & $57 \cdot 0$ & $54 \cdot 31$ \\
\hline "12 & $53 \cdot 5$ & $59 \cdot 5$ & $56 \cdot 25$ \\
\hline , 13 & $45 \cdot 0$ & $62 \cdot 5$ & $54 \cdot 23$ \\
\hline , 14 & $46 \cdot 0$ & $50 \cdot 0$ & $48 \cdot 00$ \\
\hline , 15 & $42 \cdot 0$ & $52 \cdot 0$ & $47 \cdot 65$ \\
\hline \multicolumn{4}{|c|}{ Mean Temperature for $26+$ hours, $48.88^{\circ}$. } \\
\hline
\end{tabular}

If this will not satisfy the appetite of the cold-loving hero, I will gladly invalid in his favour.

Let us now review our proecedings of late. We have all been absolute boys,-some old ones nevertheless. 
We leave (I am as bad as the rest) our warm cabins, at say $50^{\circ}$, rush on deek and on to the floe, after seience or Brum, it matters not, at-take the mean, $-49^{\circ} ; 49$ $+32=81^{\circ}$ below freezing, and $50+49=99^{\circ}$ change of temperature, without damage!

We have throughout been thinking, or rather talking, of ourselves-we do happen to think more deeply of the crew; but thanks to the unremitting attention of our medieal men, and to the general care taken to prevent exposure, I should be disposed to assert, in my proper eapacity of the Commander, that no offieial report of frost-bite has yet reached my ears. To deseend perhaps, and allow that once one of my men "took his Captain by the nose," under pretenee that he thought his Captain's nose was frost-bitten, and his warm (?) hand eould restore it, "is not quite true." But I totally and indignantly repel the very low insinuation, and believe that the blood from his heart flowed so rapidly to the end of his arm, that it saved my nose by the applieation of the back of his warm hand, and I thank him: even if it was a deeeit, I forgive him. We command here; no bed of roses nevertheless-no absolute command is! Ask the father's of families, and this is not a small one !

'To continue the matter of low temperatures. They made no impression here; the pains of forehead or lungs some might have experieneed, but they were never mentioned in my presenee. The only projeetion.about whieh I felt interest was my nose, and mpon this point (not a very prominent feature) I felt a sort of monomania, something like, going into action, that I must be wounded in a leg, and nowhere else. I never intended to be killed, 
and so I told ny surgeon when that idea was realized, but I am eonstantly asking people to view my nosc. But as I have so far wandered into self, and I know that eertain professional men who interest themselves about me will expect to know, I will merely say that I expeeted certain wounds, ents, frost-bites of youth, ete., to trouble me. I lave suffered intensely, nore than ean be explained, but nothing to disqualify me, in any namner, for this important eommand, or the liabilities attaehed thereto. My feclings are my own; so long as I perform all my duties, who eares for them?

Our present temperatures are low enough to satisfy most men, but if, in truth, $-90^{\circ}$ can be truly found in this region, I would almost stop to see it.

INerenry.-The freezing-point at which pure mereury (not impure amalgams of spurious mereury at low prices, but volatilized, distilled, adapted for thermometers, ete.) should eongeal still eontinues to haunt me. Unfortunately, I left behind me every work on this subjeet to which I could, as to late date, refer. That $-39.5^{\circ}$ is not the eorreet point of eongelation our standard mereurial thermometers prove, nor do they always eontraet to the same division. The eongelation of mereury does not appear to form any part of the acknowledged divisions on these thermometrie (?) instruments : the mereury thermometers supplied to this Expedition from Greenwieh, as well as Kew, were graduated bclow $-40^{\circ}$. I had myself remarked that no notiee was taken of them in the record, under the assumption probably that they eonld not, dare not, aet eontrary to print, but I ventured to differ, why I will statc. 
On the 17th Dceember I had noted that the mereury thermometers did not ecase to act at $-40.3^{\circ},-40.0^{\circ}$, $-40 \cdot 0^{\circ}$ : this exeitcd my attcution; weekly I transcribe the register. On the 2Sth I noticed that the registry of all the mercurial thermometers ceased at the same indication, - on the 4th January at $42 \cdot 3^{\circ}$, by standard. Unfortunately I did not notice it earlier, but on the 23rd of January, on my copying the rough register, I inserted the following order:- "The mark $f$ to be prefixcd to $\mathrm{D}$ when the mercury is eongealcd; $p f$, when partially congcaled. The numbers $19,35,34,2$, read to $-40^{\circ}$ and below. The divisions below must be estimated, i.e. the point where it congcals, or declincs moving further." He (Mereury) had stopped most religionsly at $-39 \cdot 3^{\circ}$, $-39 \cdot 2^{\circ},-39 \cdot 0^{\circ},-39 \cdot 0^{\circ}$; but in this ease he was under martial law, and he knew he must move. I suppose he made his mind up to it, for I find the following curious register, taking care to satisfy myself frequently by personal inspeetion.

\begin{tabular}{|c|c|c|c|c|c|}
\hline Noon. & $\begin{array}{l}\text { Standard } \\
\text { Spinit. }\end{array}$ & 19 & 35 & $3+$ & 2 \\
\hline Jamuary 26 & $+3 \cdot 0^{\circ}$ & $42 \cdot 0^{\circ}$ & $42 \cdot 0^{\circ}$ & \multirow{7}{*}{ 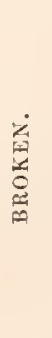 } & $+1 \cdot 2^{\circ}$ \\
\hline$"$ & $+6 \cdot 2$ & $\mathrm{Est}^{\mathrm{d}}+6 \cdot 0$ & $50 \cdot 0^{*}$ & & \\
\hline ", & $45 \cdot 4$ & 46.0 & $49 \cdot 0$ * & & \\
\hline , 31 & $15 \cdot 7$ & $45 \cdot 0$ & & & \\
\hline February 3 & $42 \cdot 9$ & $42 \cdot 0$ & $42 \cdot 0$ & & $41 \cdot 0$ \\
\hline , 10 & $41 \cdot 7$ & $41 \cdot 5$ & 41.5 & & $40 \cdot 6$ \\
\hline,$\quad 21$ & +4.5 & $4.2 \cdot 5$ & $42 \cdot 5$ & & $+2 \cdot 0$ \\
\hline
\end{tabular}

* How came this change? 


\begin{tabular}{|c|c|c|c|c|c|c|}
\hline \multicolumn{2}{|l|}{ Noon. } & $\begin{array}{l}\text { Standard } \\
\text { Spirit. }\end{array}$ & 19 & 35 & $3+$ & 2 \\
\hline February & 21 & $43 \cdot 8^{\circ}$ & $43 \cdot 0^{\circ}$ & $43 \cdot 0^{\circ}$ & \multirow{9}{*}{ 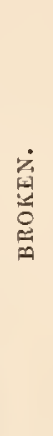 } & $43.4^{0 \%}$ \\
\hline & 22 & $45 \cdot 1$ & $44 \cdot 0$ & $44 \cdot 0$ & & $43 \cdot 2$ * \\
\hline$"$ & ", & $42 \cdot 2$ & $41 \cdot 3$ & 41.2 & & $41 \cdot 2 *$ \\
\hline$"$ & ", & $41 \cdot 6$ & $40 \cdot 6$ & $40 \cdot 6$ & & $40 \cdot 0^{*}$ \\
\hline " & 26 & $42 \cdot 1$ & $41 \cdot 0$ & $41 \cdot 2$ & & $41 \cdot 0$ * \\
\hline$"$ & $"$ & $42 \cdot 3$ & $41 \cdot 2$ & $41 \cdot 2$ & & $41 \cdot 0 *$ \\
\hline " & ", & $\pm 2 \cdot 0$ & $41 \cdot 0$ & $41 \cdot 2$ & & $40 \cdot 6$ * \\
\hline March & 3 & $43 \cdot 3$ & $42 \cdot 2$ & $42 \cdot 2$ & & $41 \cdot 9$ \\
\hline ", & 8 & $44 \cdot 2$ & $41 \cdot 2$ & $41 \cdot 3$ & & $41 \cdot 1$ \\
\hline
\end{tabular}

After all this, I ask, who will dispute the power of a Captain of one of Her Majesty's ships-of-war? Noon he has invariably controlled,-eight A.M. and eight P.M. also; but here the thermometers are compelled to eondemn themselves or the mercury.

With these matters fresl on my mind, I eonstrueted the mereurio-aleoholic thermometer D, being a glass-stem

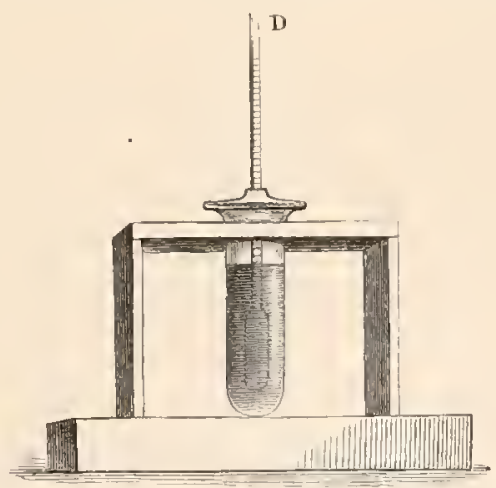

* If mereury freezes at $-39^{\circ}$, how is it that it continues to rise and fall, in conformity with the spirit, between $-39^{\circ}$ and $-46^{\circ}$ ? 
spirit-thormometer with graduated stem inserted into a test-tube eontaining four oumees of pure mereury, woll corked and covered with four layers of bladder, to protect it from the air; it was self-balanced in a kind of test-raek, and admitted of a pendulum motion to deternine its freczing-point.

It happened however, unfortunately, that this thermometer never did its duty satisfactorily, and all its reeords are in such a state of eonfusion that they have been rejceted. We may not, it is true, be confined to this high latitude, but it is probable that we may have an opportunity of pursuing this investigation more rigidly at stated temperatures next season.

Next to mercury, it occurred to me to partially freeze Allsopp's ale, and reserve the unfrozen fluid for future examination: congelation took place at $22 \cdot 5^{\circ}$. That frozen and draincd from onc-third of the fluid, when again reducel to a fluid state, was very insipid; the remainder concentrated. * 'This mode of coneentrating' cider is practised in Aneriea, three barrels making one of good quality.

Januay 24.-Already we begin to fecl the increase of daylight, four hours (between ten and tro) being now available. The light red tint of the southern horizon also intimates that the prodigal (sum) may shortly be expeeted to cxhibit his cheering and animating rays: we shall probably exhibit a sort of chamelcon tinge, inclining to dead tea-green or an incipient ease of jaundice!

The late extreme cold induced me to make experiments

* This concentrated has been tried since my arriral in England, and found to be excellent-quite a liqueur. 
upon the expausion of alcohol under low temperatures. The instrument for this purpose was furnished by $\mathrm{Mr}$. Glaisher, of the Royal Observatory, as well as a supply of the same spirit from which his thermometers had been filled. Unfortmmately those who operate in England seldom dream of the mean temperature under which such observations would be conducted here, and have failed not only to supply gloves adapted to $-50^{\circ}$ or $-60^{\circ}$, but also to warn those who may not lave brought their brains with them, that $10^{\circ}$ to $20^{\circ}$ below the congealing point of mereury is hot work. 'The raw experimenter might easily lose his hands or life, should he inadvertently take up the bottle containing half a gallon of aleohol at $-5 \mathrm{~S}^{\circ}$ or $-60^{\circ}$, withont the hands being properly proteeted.

We find that the unfortumate artilleryman, servant of Colonel Sabine during the voyage of Sir Edward Parry in 1819, in eonsequence of endeavouring to resene the dipping-needle from the flaming Observatory, was compelled to undergo amputation of part of four fingers on one hand and three on the other; and it is but natural to suppose, from all the causes then in action, that the instrument itself eould not have cooled down below $-43^{\circ}$, the prevailing temperature away from the fire: what then would be the effeet of a person tumbling and breaking a bottle of alcohol, and shedding it over his hands and person at the temperature of $-5 S^{\circ}$ ? Even with double gleves, lined with fur, I felt the cold sharply, and my hands generally suffered, but more particularly the nails and points of forefingers and thumbs, throughout the winter, rendering adhesive straps neces-

roI. 1 . 
sary to close the eracked skin; resulting solely, I believe, from eonstantly handling metal instruments and tools at very low temperatures. The affeetion was so severe, that I termed it the finger fever; all the nails being more or less affeeted, and, as they advaneed, exhibiting corrugated transverse ridges, witl spots oceasionally; however, I eventually found that these experiments could be satisfaetorily condueted in the Observatory, after cooling the materials outside, by eonsenting to the loss of a few degrees.

Better however that I should suffer, than, by any negleet of mine, some other unfortunate of lower rank should be erippled, and obtain but very inadequate remuneration,- - although loss of fingers to me would be very little short of loss of life. I think my spirited and talented friend, Mr. Glaisher, might have whispered, "But, my good Sir, when aleohol is reduced to $94^{\circ}$ below the freezing-point of water, pray take care of your fingers." True it is that, internally, aleolıol is a hcating spirit, but we have no nanle for it under these burning circumstances. 


\section{CHAP'TER IX.}

Rise of Temperature.-A Bear shot.-Termination of Darkness.-Reappearance of the Sum.-Death of a Marine,-Cold Period of March. - Table of Temperatures.-A She-Bear and her Cubs.-Sledges inspected.-Feet Wrappers.-Departure of the Sledges.-Beacons.Cains._Parhelia.-Inland Excursion.-Wavy Ice,-Cooking Ap"paratus.-Lamps.-Return of Depôt Division.

ON the 26th of January we cxperienced the wind strong from the sonthward, with heavy snow-drift; the temperature rising with the wind and spring-tide from $-42^{\circ}$ to $-31^{\circ}$. From habit we now eonsider $-40^{\circ}$ as our seale, $-30^{\circ}$ being talked of as the eomfortable, or not unbearable, travelling temperature: I dissent from any such absurdity. If we should remain many years longer in these regions, I really begin to fancy, provided we could bring our inclinations to agree with Esquimaux food and eondition, ete., that we eould endure any eold under the moon, for we are now perfeetly satisfied that nothing here, under the sum, would be umplcasant. Latterly I have extended my walks to the summit of Mount Beaufort, with a temperature of $-44^{\circ}$; but, although the simple exertion of aseent proved impleasant to the lungs, 110 sensation of cold cqual to that produced by a low 
temperature of $-20^{\circ}$, with light breeze in the face, was expericneed.

January 28.--Early this morning, about two A.M., the dogs gave notice that a stranger was in the grounds, and, by their yclping, probably within a few yards of the Observatory. Lieutenant May and Mr. Pym followed up the "cry," and, led forward by the dogs, came up with a bear, which was brought to bay by the dogs on an elevated ice hummock. Poor Bruin was evidently puzzled, doubtless ealculating on being beset by so many wolves; but his fate was soon settled by a rifle ball, when the dogs rushed in, and would, if not kept down, have made a warm meal. Three of the pups, evidently quite maccustomed to be in such presence, were very daring, but fortumately eseaped unseathed. Even at this carly hour volunteers were found to flay and bring in the skin ;no accounting for taste!

About this period I construeted a vane, to determine the effect of the direct force of the wind on a thermo-

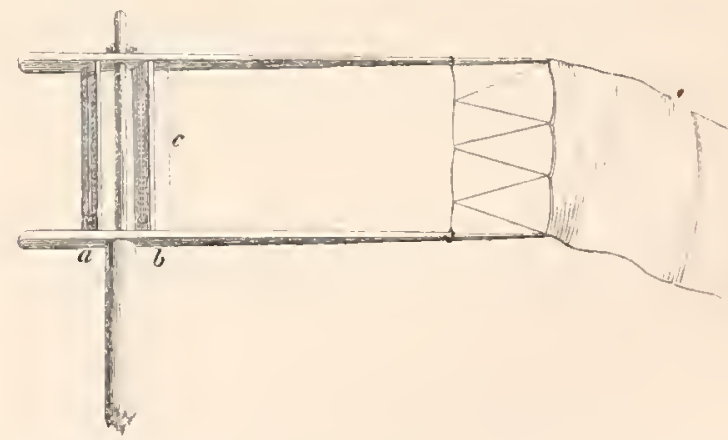

meter exposed to its full influence, $\iota$, compared witlı its opposite, sheltered, b. The results were too trifling to 
afford any reliable result. The dotted line $c$ represents the eovering board on the lee side.

This will elose the month of January: not mueh unlike a gloomy English November, but not at all realizing the very eheerless long winter nights whieh have been so frequently dimned into our ears, that I was almost indneed to think of sleeping them away on "eider-down beds ;" but, no less strange than true, these were recommended as absolutely indispensable!

February eommenees our first spring month, and we begin truly to feel that the days pereeptibly lengthen. All are looking anxionsly forward to the 1Stll, for the reappearanee of our eheering lmminary, whieh will find our travellers in high spirits and with some impatienee to try their powers on the floe.

About the 14th and 15th the weather underwent unexpeeted ehanges, the temperature rising as ligh as $2.5^{\circ}$ above zero. The magnetometer also has of late exhibited such sudden and ineomprehensible disturbanees, that I determined on the eonstruetion of an independent direet instrument, on the plan of the old portable Deelinometer, but in the present ease substituting a heavy nine-inel magnet for the magnetie teleseope, and introdueing, in Y's beneath it, a brass teleseope (adapted from my sextant), with the seale engraved on miea and plaeed in eontaet with the objeet-glass. A house was also eonstrueted of snow brieks, affording a distance of twentyfive feet between the two instruments, and a lugge bloek of iee introdneed for the pedestal. *

On the 18th our younger men aseended Britannia

* This instrument came into action on the 21st of March. 
Mount, about fiftecn hundred feet above the sea-level, in order to observe the sum at noon. On Mount Beaufort, about two hundred feet above the floe, they were preparing the base of a very large eairm, or tower, to mark our visit and place of wintering. A eheer from this party afforded me the agreeable tidings that he was secn from thence; and had it been the Houses of Parliament in flames, we could not lave hastened up the Mount with greater anxiety. There he was at last! Many and very dry questions were put by some of our humorous tars. He appeared very much distorted, like an oblong gricliron, and but just showed his golden but intensely bright rays over the outline of the distant southeru hills.

The preparations for ice travel are now assuming a more active and decided eharacter. The order to be ready for service on the 15th of March has gone forth, the erews are all told off, and the respective sledge bamners assigned, to be formally delivered at the general revicw. My own peculiar ideas of the weather about the 10th of March will prevent any deeided motion before that period. Many now are the discnssions which take place as to the possible rontes which Sir J. Franklin may have taken; but I firmly believe, from what most of us have witnessed, that, if he entered this Polar Sea "to follow the pack," no ship ever construeted could withstand its eustomary pressure. If he entered the Great Aretie Ocean, or Polar Basin, there he might be drifted for ever; for it never can, in my mind, be at rest. These reflections however belong rather to the end of our cruisc. If he passed throngh Jones's or Smith's Sounds, it is possible we may have the happiness of mecting some of his 
party among the Esquimaux, for I never ean divest myself of the impression that their parties still continue to visit those lands.

February 27.-On this morning, the anniversary of my own birtli, died suddenly, but not unexpeetedly, William Cutbush, Marine. From the period of quitting England he had been suffering from pulmonary disease, and I eamnot but express my surprise that suel a man should have been seleeted or allowed to embark on sueh a service. In England he might have lived years: here his deatl was inevitable. To the publie authorities I leave the ease, as that also of our Marines generally. He was interred on the summit of Mount Beaufort, and over his remains that huge stone pyramid will be ereeted: a stone, to which a leaden plate is seeured, bears the following, struek with metal punehes:-

\section{SACRED TO THE MEMORY OF}

WILLIAM CUTBUSH,

Private, Royal Marines, of H.M.S. Assistance,

Natire of Northiam, Sussex,

Who died on board on the 27th February, 1853, after a protracted illness, from disease of the lungs, AGED 34 YEARS AND 4 MONTHS.

He served with credit in the Royal Marine Corps for a period of 16 ycars 4 months, earning two badges and the Syrian Medal; twelve months in H.M.S. Assistance, respected by Captain, Officers, and Crew, and beloved by all who knew him; and died deeply lamented by his shipmates.

"HAPPY ARE THEY WHO DIE IN THE LORD."

I was unfortunately (possibly from taking severe cold in examining the exeavating of the grave) ineapaeitated from performing the last eeremony,- the first time in my 
life. Commander Richards, attended by the officcrs and erews of both ressels, officiated.

February 28.-Time flies! here is the last day of February: daylight at eight, temperature still hanging between $-37^{\circ}$ and $-47^{\circ}$, and our "third portion" of the winter fast approaching.

March 6.-The temperature for the last two days has maintained a mean of $-52 \cdot 53^{\circ}$ and $-52.29^{\circ}$; maximum $-47 \cdot 5^{\circ}$, minimum $-57 \cdot 3^{\circ}$; enough to satisfy the greatest epieure that there is a cold season between February 27 and March 10! Possibly I should be one of the foremost to ridicule any man who asserted that any laws guide these matters; but rain is expected at St. Swithin's, summer commences in Canada and Nova Scotia ahmost to a day, and if any one will take the trouble to consult metcorologieal journals of cold elimates, he will be able to fear cold, at all events, at particular dates: many ehances at dice are ealeulated to mueh greater mischief and with almost unerring precision. But I shall not be satisfied until the 10th, or even the 15th, is past: no travellers will move beforc the latter date, and my movements depend very much on the matter. My chief object is to push across the depôts to the south side, between the 10th and 25tll, for I have my misgivings if the final change, adapted to long journeys, will take place until the 25th. The orders however still stand for the 15th of March, and on that day the crews will be mustered.

Mareh 13.-On the next page will be found a table of temperaturcs, embraeing the last ten days, with the preceding maximum temperature. 


\begin{tabular}{|c|c|c|c|c|c|}
\hline 15. & & Maximum. & Minimum. & \multicolumn{2}{|c|}{ Mean. } \\
\hline March & & $-16 \cdot 0^{\circ}$ & $-355^{\circ}$ & $-22 \cdot 60^{\circ}$ & \\
\hline ," & 4 & $37 \cdot 0$ & $49 \cdot 0$ & $46 \cdot 27$ & \\
\hline , & 5 & 475 & $57 \cdot 3$ & $52 \cdot 93$ & $\circ^{\circ}$ \\
\hline , & 6 & 49.5 & 54.5 & $52 \cdot 29$ & $a^{2}$ \\
\hline$"$ & 7 & $45 \cdot 0$ & $58 \cdot 5$ & $51 \cdot 96$ & $i$ \\
\hline " & 8 & $38 \cdot 5$ & $46 \cdot 0$ & $41 \cdot 54$ & to \\
\hline ", & 9 & $31 \cdot 5$ & 40.5 & $36 \cdot 83$ & 可 \\
\hline , & 10 & $29 \cdot 5$ & 40.0 & $35 \cdot 0 s$ & $=$ \\
\hline ", & 11 & $34 \cdot 0$ & $45 \cdot 0$ & $39 \cdot 94$ & $\stackrel{?}{\Xi}$ \\
\hline , & 12 & 34.5 & 40.5 & $38 \cdot 13$ & $\stackrel{3}{=}$ \\
\hline, & 13 & $31 \cdot 0$ & $40 \cdot 0$ & $37 \cdot 6+$ & \\
\hline , & $1+$ & $14 \cdot 0$ & $33 \cdot 0$ & $26 \cdot 50$ & \\
\hline
\end{tabular}

On the 14th of March the Surgeon inspected the crews, and reported-sound.

The ontlines of the land are now becoming very distinet, and I have strong impressions that some of our neighbouring inlets may afford a nearer course to the Northern Sea; but this I cannot venture to look into until I have pushed this depôt aeross to Cape Lady Franklin. All our sledge crews are now eager for the work; and if any vestige remains, northerly or southerly, our parties this season will, I feel quite satisfied, settle the question most satisfaetorily.

The morning of the 16th of Narch diseovered the same old lady and her impudent cubs again on their way hither. This time it was detcrmined that order and method should prevail, affording general amusement. All hands were summoned, and the sportsmen 
par excellence were to be secn carcfully loading their gums. No one was permitted to slam a door, or quit the ship; the utmost eaution was observed. Our leading sportsmcn were passed to the 'Pioneer,' one division in readiness to push to the south-west, another party to the south-east, the scven dogs and sportsmen about south. I did not join the hunt. However, some men there are who will spoil sport : who he was I know not, but before the enemy was within shot, he fired. The dogs however, on this oceasion, did the busincss. Keeping the old lady in eonstant alarm and worry for her cubs, whieh the dogs dashed at, the sportsmen soon got within sensible firing distance; she fought nobly for her cubs, but it was useless to contend with musket-balls. All three were killed! - not however before the mother had given our prineipal, but worthless dog, a scrateh which sent him away yelping, siekening him of sueh work for the future: a Dane, not an Esquimaux : he afterwards committed thefts and other improprieties, and ended his troublesome life by an aet of suicide, with a spring-gun set for a wolf.

On the 17 th of Mareh a most deeided change took place in the weather, the temperature rising, at noon, to $+5.5^{\circ}$, on the 18th to $+21 \cdot 5^{\circ}$, and on the 19th to $+14 \cdot 6^{\circ}$. I consider the 17 th, therefore, as the break of the season.

We now cleared away the hole for the tide-gauge under the stern, cutting through seven feet of iee. Owing to the daily increasing weight of the surrounding snow, the iee began to give under the pressure, and around the ship in particular the snow beeame uncomfortably wet. Taking the height of snow above the solid ice at fiftecn 
feet, and the mean thiekness of icc at six fect, we should obtain twenty-one feet as the apparent thiekness of the floe within twenty yards of our sides. All the iee be. tween us and the 'Pioneer' is mueh thicker, and that betwecn us and the shore grounds, where we had onr tide-pole in sixteen feet! The bona fide off-shore floe of a season does not, I believe, exceed six feet in thiekness, and should you come into eollision with it, will find any inerease quite imnaterial : it does its work as surely as an ieeberg of six hundred feet.

T'o return to our tide-pole: no sooner had this hole been eompleted, than the water rushed up similar to an Artesian spring, covering our promenades with about ten inehes' depth of water, and eausing some fears for the sinking of the snow wreath before alluded to, now representing, very prettily, a leavy white roller about to overwhelm the ship.

At times I did not feel quite satisfied that mischief might not occur. Our fire-hole, abreast of the ship, lad been kept open all winter, and no sueh overflow as this had occurred. Taking also into eonsideration that the enormous weight firmly attaehed to both sides might, by some sudden movement, be released on either; the strain which any sueh sudden aetion must produce would materially injurc the ship. We had no remedy but to "let well alone," - and all would probably in due time work its own course, irrespeetive of any feeble efforts that we eould make; independent of whieh, it was not a time to weary our erew with any umeessary exertion. With the low temperature which must yet prevail for some timc, and probably below zero, this must 
soon freeze into a still more solid mass. I began now to repent laving altered my determination, of weeks past, to start the depôt on the 16th: but we live in glass houses. If any aeeident resulted, and the party had started before the 21 st, blame would have been heaped on me. "Suecess is wisdonl ;" but to keep up suecess, leave no hole in your jacket ummended. I was persuaded easily (for this reason) to await the 22nd.

On the 17th of Marcl it was ealm, with the thermometcr at $+1^{\circ}$. I inspeeted eight sledges, —officers and erews,-in travelling order, and eomplete as in tables in Appendix. The first division, now about to start, under Commander Richards, numbered six sledges.

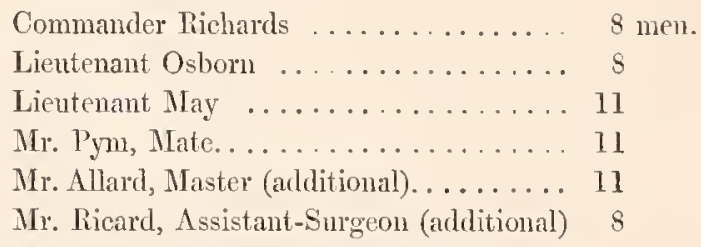

57 Men. 1770 Rations.

On the 19th, blanket wrappers, travelling-boots, mits, ete., were completed. I am not aware that these subjeets have been diseussed, but they are matter's whieh to the landsman require explanation; and where sueeess attends any partieular mode of dress, any habit of travel, ete., it beeomes of importanee to the general interests of this serviee that it should be reeorded, for good or evil, to be followed or aroided. Hitherto all our attention lias been most intensely direeted to the foot equipment. I have throughout disliked the enrpet boots: for travelling they are useless. The last Expedition, I believe, 
established the canvas boots,--the IIudson Bay eustom, the blanket wrapper. 'This latter is formed of a picee of good thiek blanket, of at lcast fifteen inehes square.

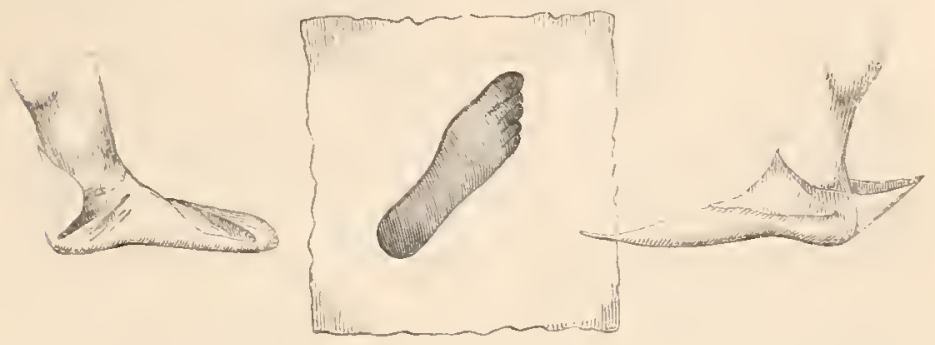

It is very important that these feet wrappers should be well put on, and elastie soeks should have been provided to keep them in their places: the stoppage, to replace them, will seldom be permitted; and exposure to eold in doing so may inflict frost-bite. The boot must not be tight, and no pressure should be allowed at any part: I fear the eanvas straps on the instep of those now made may prove injurious.

March 22.-At 7.30, temp. +220.-The depôt-sledges, eliarged with fifty days' depôt for twenty-four men, or twclve hundred rations, independent of ten days' for the party, eonsisting of sixty-seven men, took their departure, under the eommand of Commander Rieliards, the remainder of the erews aeeompanying them to the point where they all made sail; each sledge being fitted either with sheers or masts, aceording to their separate idea of sledgemanship, and using the tent bottom, about nine feet by twelve, as a sail. They earried also with them a whale-boat and light iee-boat, on sledges prepared to support then. Thuse, with the depot, were to be sc- 
cured at Cape Lady Franklin, about twenty-five miles distant from our outer island, the party returning to prepare for their extended trip. The morning was fresh and gloomy, witl the breeze freshening from south-east, temp. $+22^{\circ}$; but as all were equipped and eager for a move, and I had not the least doubt as to the weather improving, I was glad to start them, and accompanied the little flect to the outer point of the bay, where we parted, giving God-speed. As they reeeded and gained suffieient distanee to be grouped, they resembled very mueh a small pirate fleet, no two preserving the same appearance of rig, and, as might naturally be expeeted at their onset, many failures and loss of spars resulted before they finally eleared the rough ice.

About ten, Mr. Allard's sledge, having broken down, with the whale-boat, returned : another was immediately equipped, and he was paeked off again at 11.50. As I strongly suspeeted, Mr. Allard reported the iee to be soft in the eraeks and very diffieult for travelling; however, our seouts from the hill saw him moving on eleerily towards the outer island before nightfall.

On the 23rd the morning proved dull, but the day turning out fine, with a temperature varying from $5^{\circ}$ to $10^{\circ}$, I took advantage of this lull to resene our thermometers, buried in the snow-heap sinee Oetober 25 , but now sinking very pereeptibly, owing to the general diffusion of water over the surface. 'The objeet in view was to prove the question, as to what distanee or thiekness of snow eold will penetrate vertieally, or horizontally. Six's thermometers, if properly eonstrueted, will register maxima as well as minima temperatures; but I must 
candidly say, that I never saw but two that stood their work, and they belonged to a water-bottle, eonstructed for me for obtaining water and determining the temperature at cxtreme depths (twelve liundred fathoms or more), that could be relied on. 'The block of snow in question measured sixteen feet by eight on the surfaee, was eight feet in height above the iee of the fioe, and eonstrueted of large bloeks of solid snow, cemented at the joints, or "pointed," with wet snow, which in a few minutes formed into ice. The interior was filled in and well trodden with loose snow, spars being placed where the thermometers were to be inserted : their withdrawal left firm cylindrical holes. Next to the more perfect operations of Dame Nature, this, I believe, comprehended all that was desirable. The diagram will exhibit the disposition of the thermometers, inserted when the temperature was at zero and their indiees set.

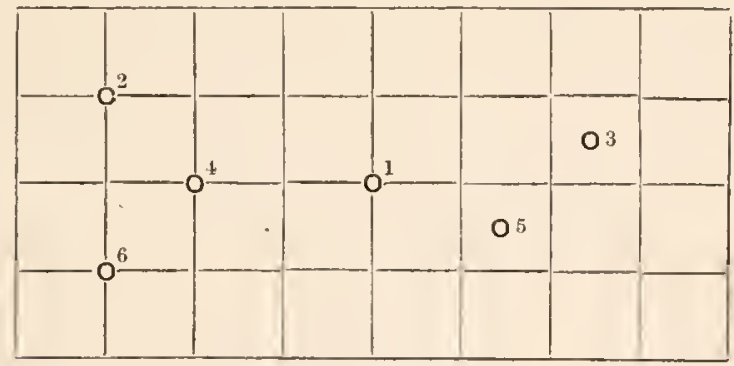

No. 1, centre, 4 feet from N.E. and S.W. sides, 5 from N.W., 6 feet deep.

No. 2, 2 feet deep, 2 feet from sides.

No. 3, 3 " , 3 , , ,

No. 4, $4, ", 4, ", "$,

To. 5, 5, , 5 from S. and E., 3 from $\mathrm{N}$.

No. 6,6 , , 2 from sides. 
But great confusion in withdrawing them oecurred, by which all confidence was destroyed. The results I lave; and they convey to my mind merely the fact that this bank of snow did withlstand a much greatcr amount of eold than I had contemplated, but they wcre not spirit, nor reliable, instruments. About this period also, and whilst Commander Richards was absent to the southward, I tried several experiments on illuminating beacon poles by sheets of tin; a cask was also eovered with tin-foil, etc.; but unfortmnately the point where he landed was not in sight from the Observatory lill, where thicse marks were ereeted, nor did his track permit his noticing them. A variable or revolving heliotropie vane was constructed; but the cold, acting on the metal spindle and eollars, did not permit it to traverse freely ; it may be deseribed in the Appendix.

The customary labour, and wear and tear of clothing generally, in the construction of cairns, is overlooked by our superiors when thcy issue orders on these licads: one half-hour injures boots, mits, and clothing, more than can be conceived. Nor can the officer look idly on: he therefore fecls, as well as sces, the necessity of providing special gloves or hedgcrs' mits for this duty. I directed extra boots and mits, faced with senl-skin, to be issued to the caim builders of my own division, where these dutics entailed on them especially, this laborious speeies of work, and for which no provision lad been suggested.

In our prescnt occupation of adding to the building on the summit of Mount Beaufort, day after day, using carts to bring up the stones, the wcar and tear of elothes 
was also found to be very tedious.* Independent of our instructions, the woukl-be monitors, who write to sce themselves in print in the public journals, insist on our building cairns in even impossible localities. If any of these should be lonourable (right or wrong) Members of Parliament, I would advise them to amend the next vote for Arctic Scrvice by the increase of the supply for the purchase of gloves, etc., as well as of some simple succedaneum for the cairns thcmselves. It is not often that stones can be found, and when found, that they can be detached from thcir icc-bound beds. Many shovels and picks $\nmid$ are destroyed, which break easily in cold weather. Our prcdecessors omitted to hint at this; indeed many liere have kept their secrets most religiously, to our discomfort. But it is rcally grating to my feelings to hear the oft-repeated tale amongst my crew of "how many pairs of mits they bought, how many were supplied by Government, and that they are now reduccd to take up Purser's." In this manncr the Commander often hears very unpleasant truths, beyond his power to remedy!

March 25.-The depôt division having departed, and left me frec, I determined to avail myself of the interval by exploring onc of the creeks at the southern end of this Sound, which seemed to promise some cliance of connection with the Northern Sea. I was under the impression that it might possibly, by slight portage, enable

* In England pay might cnable a man to derote part of the sum given for the endurance of such a climate: but no moncy here could buy a serviceable pair of gloves or clothing!

$\dagger$ All these tools were wretched, very inferior even for ice, and kept our blacksmith constantly employed.

VOL. I. 
us to throw across our depôts, avoiding some days' troublesome and circuitous travelling. Accompanicd by Mr. Loney, and a sledge crew of six, with four days' provision, and the Cape York dogs, we started this morning about eight A.M., under the "Blanche" banner- " Bright eyes for brave hearts." The bright eyes prevailed: temperature $-5^{\circ}$, wind in our teeth! We reached the entrance of this creek about noon, where we lunehed, and I ascended the peninsula, to make sure which of two openings I would select. The south-eastern appearing to offer greater advantages, I deeided on it. As we advanced, the deep ravines and steep beetling cliffs seemed to invite a more distant lead of inlet easterly. The wind was now not only sharp, but strong from the south-east, rendering it difficult, over polished iee, denuded by the wind at every swell, from keeping our feet or making progress. This was more particularly experienced under the glacier of Mount Blanehe, and its ligh cape within, which reminded me of the gales off Cape Sicie of old (do they blow since the Peace?), and this appellation I bestowed upon it. It resulted elearly from the configuration of the land, as the breeze altogether ceased as we passed into the depth beyond. Recent deer-marks, ${ }^{*}$ or those of musk-oxen, were noticed on the snow patches of the peninsula, but side by side, as if four animals had walked abreast. But these snow indentations are so very deceptive, that I do not place great reliance on them: one head is worth a thousand feet. Our journey ended

* They were not deer-marks, and the latc appearances in this country induce me to think that this form is frequently produced by snowilrift. 
abont four P.M., at the further (south-east) end of the ereck; but the valleys evidently connceted, north as well as south, with the other interior opcnings, particularly towards Hungry Island. During the time the men were occupied in pitching the tent and preparing supper, ete., I strollcd up the mountain until I almost "found mysclf" on a commanding cmincnee, about eight hundred fect above the levcl. A cursory glance around satisfied me that all my anticipations, either of advance or retreat by amy of these ravines, must be entirely quashed. Still, as several heights easterly might serve to tic the work of this scason (in prospect), I determined on the morrow to make an inland excursion, and place a beacon where any emincnce to the nortlı-cast offered, likely to afford suclı a desirable conncction.

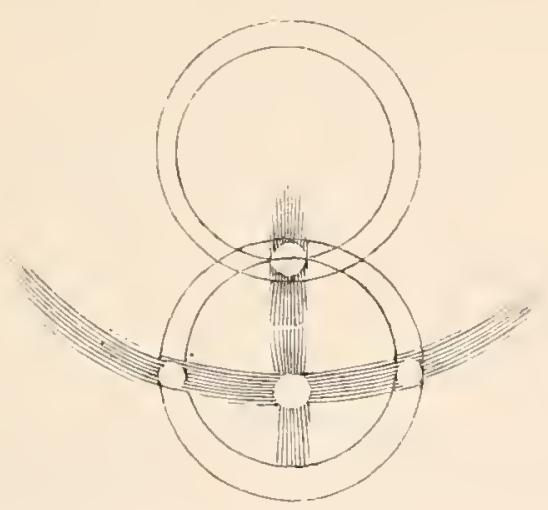

The fine drift-snow blown off Cape Sieie, and continuing suspended about that level, produced some very beautiful parhelia, dividing the arc contained between the zenith and horizon into three spaces, and forming four illuminated spots, the prismatic colours varying mo- 
mentarily in intensity. The distanee we had travelled on iee was estimated at ten miles: I notiee by the plan that it was fourteen.

March 26.-Temperature $-7^{\circ}$. Our night in the tent, being the first of the season, notwithstanding the temperature did not fall below $-7^{\circ}$, and ealm, was mueh eomplained of by all; and when a bright morning afforded hopes of eomfortable exereise at this temperature "over the hills and far away," it was mfortunatcly aeeompanied by a troublesome fresh breeze from soutleast. It is not to be inderstood that temperature here is eoneerned, beeause $-10^{\circ}$ is the approved degree for travelling - is pleasant, to our feelings balmy ; but a eutting south-east wind, eharged with fine drift, on the mountain-top, breathing heavily, is no pleasant "barber." As we surmounted the hill-diffieulties we were surprised to find around ns gently undulating surfaees, at times so perplexing in the distanee as to eonfuse the scnses, and eause one to deem them floe (or what would be level sea). Frequently did I observe, "Well, there at least is good floe to travel on ;" but very shortly this vision was dispelled by the intrusion of some headland presenting a very mueh lower level. Upwards of four hours we eontinued to advanee to the north-cast, gradually aseending in the hope of eatehing some glimpse of the North Sea. Glimpses of the horizon I eertainly obtained at times, through long lines of distant ravines; but the northern mountains, added to the great haze, put an end to all hopes of any proximity to the northern water. Seleeting therefore the nearest eminence, with regard also to building materials, a conspieuous cairn was eonstructed, 
sevell feet high by nine feet in diameter at base, and of such substantial stones as will last more than a season. My own impression was that I saw some point or island through the valley. Time did not admit of further progress, and that securing return before dark now beeame important. The cairn which we had constructed afforded some little shelter from the cutting breeze, and under this we lunched. Cold meat, of course, and a cntting eold atmosphere,-for the temperature had fallen, and our men were feeling it aloud. Between the snow-dust elonds I eould now and then distinguish certain objeets, which satisfied me that I had reached the hill whieh I had contemplated from the Observatory. Our paeking up, and forward, or return movement, was rapid;-so mueh so, that when I found myself at the tent, I resolved on seeking a more convenient shelter for the night.

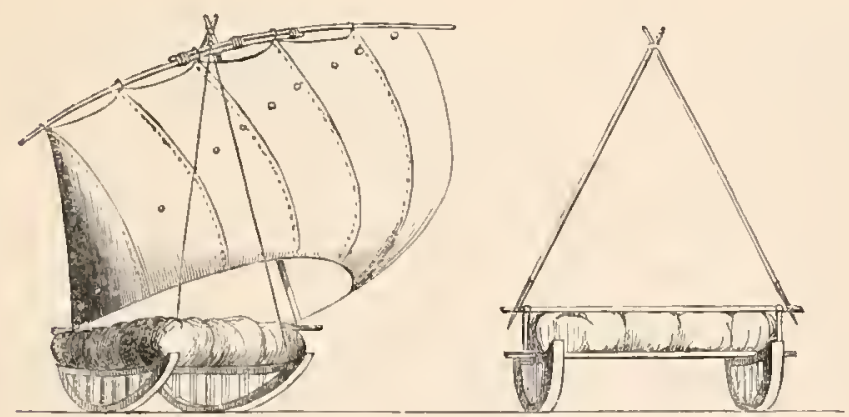

We therefore packed up, and started under canvas. Our craft was rigged in the most approved Sooloo pirate style: shecr masts stepped into a specially fitted batten, forming an isosceles triangle, with the neans of support 
by shrouds from its extremity, greater by two feet than the width of the sledge, which had also been increased for carrying the iee-boat, and our tcnt bottom was now formed into a well made sail. We were therefore "shipshape," and might easily bc mistaken for a gig under her customary lug; or, in ease of very reduced eanvas, it could readily, by elongating the yard, constructed of one bamboo and one tough mahogany fiag-staff, be eonverted into a latteen (in the line of holes from taek to yard-arm).

I lave before alluded to the floe we came ovcr, head to wind. Our progress now was somewhat swifter; but of this very uneven and cxtraordinary floc I would now speak. Whenee arises this wavy, glassy ice, unclulating at such a very sharp piteh, viz. about two feet rise from the level hollow to the vertex or erown of the sueeeding areh, or on a ehord of thirty-two feet, about two feet differcnee of level?

The agc of this iee-and it pervaded all the portion subject to this windy part of the strait-appeared great. The only rational eausc to whieh I could assign its formation was the channelling by summer thaws and the foreing the water thus produced by the prevailing gusts over the irregnlar ridges, on whieh the sun did not act: this is the more probable, inasmueh as some of the intervening spaces, eovered by the snow, presented smooth, elear bhe, level ice, in long spaces, evidently where the water had bcen quiescent, whereas all these abrupt swells were composed of grey ice, rough, and abounding in air-cells of the size of hemp-seed or peas. As I before noticed, within and withont this strait it was not met with; there the ordinary level snow-elad floe prevailed. 
We left with a gentle breeze, mder all sail, going at a very pleasant trot beside the sledge, until we came upon this rough sea. The velocity of the sledge, caused by the sudden inerease of wind under Cape Sicie, tripped all hands up and dragged them astern, face downwards. I was on the sledge, and dropped myself in time to avoid the consequences of the capsize which one of these waves eaused. IVe eseaped with one damaged spar; replaced it, and moved forward more cautiously. This time our engine ran away; again all hands let go. I was perched, for ballast, on the weather-quarter, across which a long guu-case, three feet six inches, was lashed; but, as if niy neek was destined to be continually in jeopardy, I experieneed a gentle summerset, driven at a radius of four feet, witll sufficient impetus to derange it;

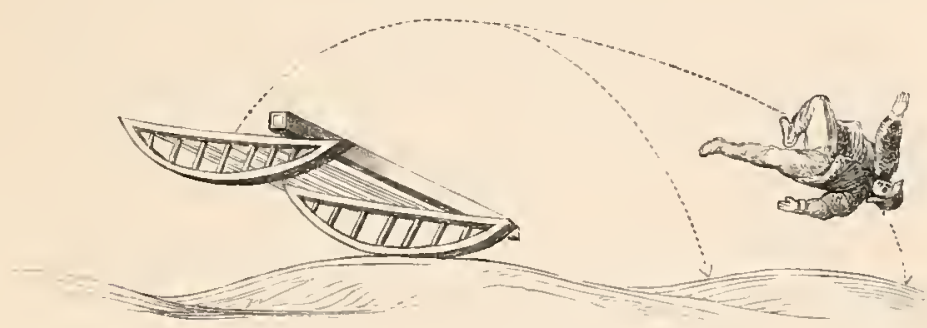

lowever, I escaped with slight damage, and the sledge upsetting on a lee shore, cnabled our erew to regain it. We now redueed our sail to a latteen until we eleared this frozen ocean, and eventually pitched our tent for the night on a fine gravel beach. 'This I well know, by experience, to be bad; but as the majority seemed to think they had bettered themselves, I was determined to let then learn, and not have to thank nue for my inter- 
posed authority. Experientia docet, when men can be made to understand it; however, stone will, like metal, take a lower temperature than snow, and will of course abstract heat in a similar proportion. Each complained of greater cold. I was silent; some smiled, few slept, but all were very glad when chocolate was ready, and it required no second call to rouse the slumberers. Dry gravel, under summer sum, is however very warm, and to be then preferred.

Striking our tent, we now moved on for the ship, but I soon found that such antics do not suit my present constitution, and that sevcre spasms of my right leg compelled me to use a compress. We reached the ship at eleven A.M. on the 27th.

On this short excursion we fortunately discovered the inadequacy of our cooking-lamps either for stearinc or spirits-of-wine. Instead of brazing, they had been simply soldered, and the first time the spirit was used, the supply-tube fell off, the spirit (the entire day's allowance) was lost, and the tent endangered; and yet these things are put into the hands of the proverbially " eareless and inexperieneed seamen!" What mechanic could dream of burning stearine or alcohol in soldered vessels! even the nozzles of the tea-kettles were so secured! Doubtless the Govermment paid very handsomely for these inefficient elaptraps, but our blacksmith had enough to do to keep them in repair; indeed we were lueky to obtain him, for the steam department did not aid us in such matters, beyond helping the blacksmith in tin-work and at the bellows. These matters at first sight do not oeeur to the uninitiated, but they are pregnant with danger, 
as well as inconvenience. Let us suppose that we had started witl spirits only, as intended; but in this ease we had a small supply of stearine.

First act: spirit-lamp defective-fecding-pipe falls off (soldered to the side and bottom, instead of top). The alcolol flowing round and below took fire, and destroyed the lamp for use. If I had not been present and made a substitute, all the fnel would have been expended. But let us imagine that the tent did take fire, what would be the condition of the party? First, loss of shelter, and, from the attempt to extinguish the firc, incritable frost-bites; the result, loss of members bitten, or life! But there are other miseries; without fuel, neither water, tea, nor chocolate to drink, could have been procured; and thirst at this scason, particularly at the conmenecment, is intenscly felt; but had such an accident occurred at the ontward limit of a journey, the result is fearful to contemplate! What then, I may ask, would be the chances in this region for our missing countrymen, if they escaped from their vessels? Fuel, cren in savage life, is requisite.

'Truly thesc preparatory journcys are valuable; they point ont our wants, and direct us to supply the deficiencies. Already cach Government stearine-lamp has been replaced by our own ship-made, and a composition formed with two parts of whale oil and one stearine, cast into plates, with wicks included to fit them, supersedes the lamp, so that lighting the firc is simply lighting the candle of some cight inehes' diameter. Some for my own sledge werc formed from bees-wax and oil. The spirit-lamp for my own sledge was superseded by a cop- 
per vessel, hammered out of the solid, with six lips for wicks, affording the facility of adding oil, or wah'us, bear, or bacon fat. These two light and simple articles are available for any purpose. Our copper vcssels have been riveted and brazed, but the kitchen itself, the outer casing of timmed iron, is already asunder! How many years have they becn warranted to last? Gone before onc scason! Very stringent orders will be given to preserve their remains for future service. The test which I would prescribe for all such articles, in coppcr (to be tinned after), would be boiling oil : if they stood this they might be rcccived, not otherwise.

Our appearance, short as our absencc had bcen, brought officcrs and crew out to help us : to that comfort we were anxious to r'cach, for our cruisc had some. what shaken me, and thc constant talking of cold which the mon expericnced, made me far from comfortable.

March 29.-Our anxiety for the return of our party kept me very often on the hill, and today, turning my telescope towards the outcr points, where I intcnded to place some beacons, I noticcd dark objects in motion : ducks they could not be, but, deceitful as the atmosphcre is on the ice, I was soon ablc to discover that they werc the hcads of our sledgc crews, rounding the spit of icc off the outcr island, whon they all, strangc to my mind, pitched their tents on the spit. I was not long in swceping the island crest and discerning that this motion was connccted with partics cairn-building; and after constructing two, thcy rejoincd the tents and advanced. Affording them time to makc their march, I took the direct path to cut them off, and joined them about two 
miles from the ship. I was glad to find them all in licalth, ligh spirits, and free from casualty; but I could read clcarly that this trip and return had proved of great importance, and rejoiced I was that thcy wcre prevented from proceeding until they had refreshed themselves and remedied deficiencies discovered on this first brush. It had proved a work of labour, but the difficulty was now diminished.

In condensing the able report of Commander Richards I shall use his own words, omitting only passages of dctail, which will probably be printed in another form. The date of starting, etc., has been already stated as the. 22 nd of March, at seven A.M., temperature $22^{\circ}$; the sledges being commanded as under :-

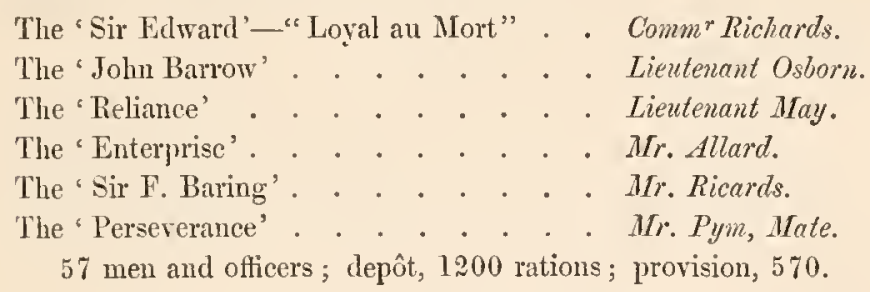

"The wind fresh from south-cast, and weather hazy, we started under sail, steering for Spit Island west extreme, and accompanied for a short distance by the Captain, officers, and remainder of the crew. At ten A.M. we got amongst liummocky ice, and the slcdge 'Enterprisc' capsized with the boat, damaging herself so much that she was sent back to the ship to refit.

"About two we cncamped on the low western extreme of Spit Island, to await the return of the 'Enterprise.' At five the 'Enterprise' rejoincd with lier boat: George 
Youngson, of the 'Perseverance,' fainted at his sledge, but a little brandy, and his dimner, recovered him.

"Narch 23. - Calm and foggy, $+8^{\circ}$. Started at seven A.M., and came almost immediately to heavy ice, which we dragged through all day, with scvere labour to the men and damage to the sledges. It was a perfect frozen pack, which we were obliged to cut our way through with pickaxes. The snow-drift very deep between the hummocks, which we found of use in making the road with. Two walrus, an old and young one, were wounded today in a holc of water, but were not captured. Encamped at 4.30, and patched up the 'Enterprise,' which sledge had suffered severely among the hummocks.

"March 24.-Light wind westerly, with thick weatler. We started at 6.45 ; at 7.35 camc to better ice; at 11 lunched : nothing important.

"March 25.-At seven A.Mr. started : wind south-cast, fresh, and hazy. Cut a road through a confused lieavy pack with picks and shovels, and after five honrs' labour succeeded in accomplishing little more than a mile, when we reached an old floe, halting at noon for luncheon. A bamboo and flag was left to mark this, 'T'he Queen's Causeway.' Encamped at 4.30. Wind strong from the south-east during the night, and the tent very cold.

"Narch 26.-Wind south-east, strong; weather thick. Started at eight A.M.; scarcely able to see thirty yards ahead for snow-drift. Many slight frost-bites* occurred amongst the men. At 11.30 halted for luneheon; althongh close to it, no land in sight; moved forward, being too cold for mndue delay. At 11.50 saw Cape Lady

* Frost-bites temporary, removed by snow or warm hand. 
Franklin elose to us. Iee very uneven in-shore, and the stupendous hummoeks which line the eonst, and whieh must have been pressed up by a sueession of northwest gales, are between seventy and eighty feet high: I should say that they have stood the thaw of many summers, and seem little affeeted thereby. The old floe whieh we pieked up yesterday did not earry us to the south shore, but a narrow belt of new iee intervenes. At 12.30 we landed on the south shore of the Queen's Channel, and planted the Union. The depôt was placed on a sloping point, about eighty feet above the sea-level, and one mile from the summit of Cape Lady Franklin, east of it. The point is projecting, and is eomputed to be the nearest land to Spit Island; the heaviest hummocks of ice are grounded on it. The depôt consists of the boat turned bottom up, with the other stores plaeed under it. Over the boat a flag was hoisted, and the eustomary reeord in a tin eylinder left."

The vegetation on that shore appeared to be more abundant as well as forward; traces of deer noticed; formation similar. Ascended the higher land; notieed eight or ten deer feeding in pairs in the valley westward: two passed within fifty yards, the doe and fawn. The return to the ship is but the outward journey reversed. Canvas boots approved, as well as blanket wrappers. Carpet boots deeried for travelling, eausing sore heels to those who used them. Commander Riehards is satisfied with the allowanee of provision, but objeets reasonably to mixture of pemmiean and preserved meats.

The sledges have been mueh strained by rough iee: that belonging to Commander Riehards so mueh shakeu 
that it must be replaced. One missing, either buricd in the floe, or in the snow on shore: the lattcr might be reeovered. But the peculiarity of losing anything on the floe may be readily understood by the faet, that a snow-house and bloek for thermometers, construeted on the floe level in October last, are now just even with the surface snow, or the level of that of the snow-bank of our port-beam, fourtcen feet above the solid iee. As the scason advances, and the sea inereases in temperature by the great amount of thaw beneath, the iee is removed from the lower surface, watcr pereolates, and the upper mass freezcs; and, as a matter of course, things whieh occupied the upper icy surface in October, must be sought for beneath it in May. Those which float may be recovered, but it may be possible that a pile of bottles, owner unknown, may yet bc extricated at the month of Wellington Channel. In November I heard rumours of such losses, and dirceted all tins and bottles to be removed to the land, that no such accident should mislead parties as to our fate. The hills have not been, so to speak, snow-clad during this season: any strong breeze denudes them, and the earth is in places ever visible.

I cannot take leave of the month of March without some remarks on its peculiar character. Of the early part of the month, or first half, I lave already made my extracts. From the 16 th, the + sign prevails as high as $24^{\circ}$, the minimum being $-18^{\circ}$. This, by referring to the comparative table of the two 'Hecla,' 'Enterprise,' and 'Resolute' voyagcs, is contrary to precedent, no plus sign occurring at all! The following comparisons will show the great pceuliarity in this month:- 
1853.] COMPARISON OF TEMPERATURES.

\begin{tabular}{|c|c|c|c|}
\hline & Махінип. & Minimum. & Mean. \\
\hline Assistance (1853) & $+24^{\circ}$ & $-55 \cdot 5^{\circ}$ & $-17 \cdot 75^{\circ}$ \\
\hline Hecla (1820). & +6 & $40 \cdot 0$ & $18 \cdot 10$ \\
\hline Enterprise (1849) & +8 & $51 \cdot 0$ & $22 \cdot 80$ \\
\hline Itecla . . & -9 & $47 \cdot 5$ & $28 \cdot 37$ \\
\hline Resolute & -8 & 41.5 & $25 \cdot 70$ \\
\hline
\end{tabular}

We have cxpericnced the month nearly divided between intensc cold and (to $u s)$ intense heat! Between the 16th and 26th we cxperieneed a change to a mcam on ten consecutive days of $+5.593^{\circ}$, and on seven consecutive days $+10.627^{\circ}$, the maximum being $+24^{\circ}$, minimum $17^{\circ}$.

I take leave of it, and bequeath it as a legacy to the speculative theorist at homc. 


\section{CHAPTER X.}

The Caim,-Anticipations. - South-west Expedition,--Tidal Motions.

-Return of Mr. Loney.-Dog Killed.-Letters from Pullen.North-east Expedition.-Tent Arrangements. - A Cold Bath.-The First Depôt.-A Wolf.-Princess Royal Island.-Tidal Rents,Snow Blindness.-Mount Parker.-A Whale,-Hamilton Depôt.

April 1.-The summer heat has already informed us that our pile must be rebuilt, and that snow or frozen stones arc not fit materials for any weighty structures. The basement, eonstructed of substantial stones, is firm, but the sun aeting on the surfaee has thawed all the loose iee-bound matter, and now eompels us to reeonstruct the upper part, which has fallen: a practical lesson on all cairns built before summer.

On the and the weather proved fine; a party was despatched to rebuild Mount Britannia beacon afresh, and to look around on the iee. This bcaeon was surmounted by a blue and yellow flag, and adorned with many preserved meat tins, flattened out, and hung in such positions (with their tinned surfaees outwards) as might afford a glimmering ray, from thesc heliotropes, to the southern travellers.

A speeimen of the stone brought to me today from Spit 
Island appears to be a bituminous shalc. It might serve, with coal, to keep up the heat, but I do not find it to be capable of burning or maintaining hcat, unless so aided.

When I look baek to my order, issued in February, "that the sledges were to be ready to depart on the 15 th Mareh," I confess that I am somewhat astonished; possibly other matters before this eruise is cuded (?) may be as satisfactory! But with the summer this habit seems to decline. 'To my own mind I think I could have found very plausible reasons for antieipating the preeeding events; but beyond my conception of the direetion of my intended route to the north-east, I have nothing now beyond guess to help me through the summer. Hope I will, nevertheless : that can never be denied. Indeed, without some preeoneeived opinion oll sueh a serviee, how am I to frame my orders? Surely not on the snail prineiple: "nothing risk, nothing gain."

I notiee the following amongst my rough notes:"I like calculations ahead, and shall divert myself with another pet theory. I have noted generally that a warm or forward spring in eold climates, even in England, is seldom elreeked by any return of eold. In April, 1852, we retained a eold spring, and carried it to Greenland, not experieneing a greater maximum temperature from 1st May, at and after quitting Stromness, than $50^{\circ}$. Summer we did not experjenee, $45^{\circ}$ being our maximum summcr temperature in August. On the Sth, at noon, the moon ehanges; and about midnight, on the 9th, we may expeet a dceided change. If a gale ensues from sonth-east we may expect high temperatures, but no travelling. I shall direct the south-western expedition to be ready to 
move on the 10tll. In arriving at this determination, I think I am even late. 'The minimum temperatures generally oeem when the travellers are in their blanket bags, and the eold is not so much pereeived. To have been present, and watehed our ehanges, might have furnished food for ridieule.

April 10.-Chis morning, at two A.Mr., our attention was intensely on the alert.

$$
\begin{aligned}
& \text { At Midnight . . . . . . }-21^{\circ} \\
& 2 \text { A.M. . . . . . . . }-16 \\
& \text { 4. . . . . . . }-14 \\
& 6 \text {. . . . . . . }-8.5 \\
& \text { 8........ . }-4 \\
& \text { 10........ . }-2 \\
& \text { Noon . . . . . . . . }-5
\end{aligned}
$$

It liad been arranged that Sunday, 10th of April, should be the starting day. The sledges were laden and inspeeted on Saturday evening. After speeial prayers on Sunday, the erew were allowed to sleep until four P.M. I took an early dimer with the officers, and shortly before four the sledge banners were presented, and their eommanders and erews severally addressed. An address was also made to the erew generally, and the entire banners being displayed, fluttering in a north-west breeze then springing up, and adding a fresh spur to our cager hands, we took leave of Rieliards and his gallant band of six sledges and fifty-seven men, gliding forth from our remaining banners, with feelings which I am unable to eommit to paper. The division comprised the same sledges as before, Mr. Herbert now taking the 'Sueeess' and Mr. Grove pro tem. the 'Enterprise;' Dr. Lyall the 'Lady Franklin.' 



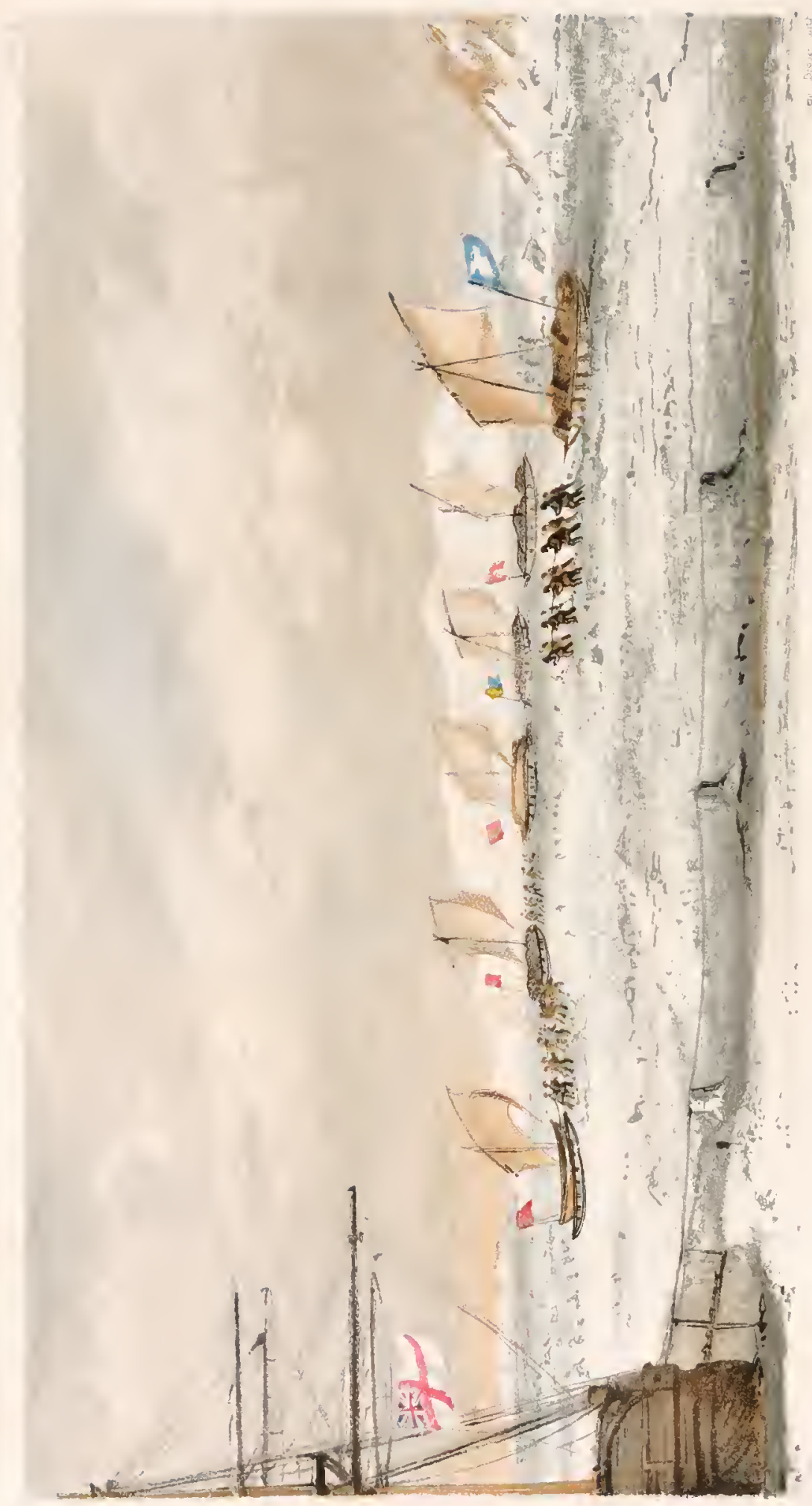


Each sledge was stored with forty days' rations for the number of men (fifty-seven), making the average dranght per man about two hundred pounds. Commander Rieliards was the bearer of despatehes for the Admiralty, viá Melville Island, as well as others for Captain Kellett, to be left at the previously ordered rendezvous in $77^{\circ} \mathrm{N}$. and $105^{\circ} \mathrm{W}$. The arrangements eontemplated the Commissariat sledges to aid Commander Riehards until he had reached the meridian of $110^{\circ}$, when he would have forty days remaining, and adequate depôts seeured for his return to Cape Lady Franklin, where the whale-boat, with sufficient provision, was already deposited; he was also provided with one of the light ice-boats.

The little fleet, having at this time their masts better secured, sails reefed, and their Commanders having in every way gained experience from their former trip, now sailed away more "ship-shape," and were soon lost to our view.

One great feat complete, I had now to revert to my own course. I had heavy difficultics to contend with, but go I must: I could not leave sueh an important trust to any one I had here. The first step was the completion of my offieial correspondenee for the Admiralty, to be deposited at Cape Becher, where I fully relied on my emissary being met by one from Commander Pullen, if he himself did not eome.

April 11. - The weather eontinuing to hold out the prospect of moderate temperatures, our mean being above zero, I determined on despatehing two sledges, under the eommand of Mr. Loncy, aided by Mr. Allard, to lay out our first north-east depôt. This was also in- 
tcnded to fcel the way for our boats, which would have to travel in that direction, as well as to determine the actual state of the ice in that exposcd locality, for I had niy doubts of a permanently frozen sea throughout the space bcyond Exmouth Island, and the region westerly and northerly.

Aprit 12.-On the morning of the 12th of April they started. About eight A.M. the thermometer ranged on either side of zero; on the 13th the temperature fell suddenly from $-6^{\circ}$ to $-12^{\circ}$ and $-19^{\circ}$; and at four А.м. on the 14 th to $-25^{\circ}$, attended by strong breezes from the westward. This continuing until the 16 th, I did not give them credit for contending against such difficulties, particularly the snow-drift we have experienced: I certainly expected they would, to use the Arctic expression, liave "bagged," or slept in their tents. 'These breezes seem to have a surprising influence on the tides, and this renders me still more anxious; for when they onee become active, the sign is infallible, to my comprehension, that, like a mob, there must be vacant space somcwhere, from whence they cane, and to which they can return : nothing but open water, northward or westward of this channel, can effect such motions. At one time I had some suspicion that the tidc-gaugc was foul, but it moved too freely, and the customary ice-cracks, termed bolts-cracking, have of late becn more loud and frequent.

April 17.-One weck has clapsed : in thrce days Mr. Grove will probably furnish me with the gratifying intelligence that the division has safely reached the southern shore. Climate and winds differ here so widely within 
a space of ten miles, that it is quite impossible to calculate on the weather they may experience. They are all sonnd men, and well attended, and will, I am satisfied, do their duty, especially ny own crew.

April 19.--I cannot snfficiently express my satisfaction when one of my own follower's exhibits a pattern of smart work. Under all the difficulties I anticipated, I find Mr. Loney returned, and his work satisfactorily exceuted, two days within the time. He had deposited the cache eight miles to the north-east of our furthest station of last year, and had from thence a good view of an island seen by ne (as in mbibus) from Exmouth Island. I then (on the 2Sth of Augnst) directed Commander Richards to look for it from his more advanced stations, but he was prevented seeing it, owing to thick weather.

The party experieneed very severe cold, travelling head to wind directly against heavy snow-drift, but withont a single easnalty (my own wcll-tried sledge crew); snow-blindness and trivial frost-bites (alias cold fingers) being the ouly diffieulties.

The day after they quitted us, Mr. Loney, aceompanied by Mr. Allard, being somewhat aliead of the sledges picking the way for the men, encountered a bear steering direct for them. At first they mistook him for a dog, and, being unarmed, they reversed their engines, and dropped upon the sledges, Mr. Bruin trotting up most fearlessly to attack the party. However, his assuranee cost him his life, but not before he had struck his awful fore-paw into the fore-sloulder of the leader of onl Cape York dogs, and literally torn it ont, rendering it necessary to put an end to his misery: he was the 
finest of a most peculiar and very liandsome brced, obtained at Cape York. As I had suspected, the water in the Main-tide Clannel, between Pioneer Island and Village Point, was open for half a mile, but on thcir return was again skimmed over, probably under a $-25^{\circ}$ tempcrature. This and one or two other air-holes noticed will probably break up the moment the sun has a fair vicw of them,-they are directly in the course of the strongest tide. One other bear was seen, but he was too wary to trust liimself in such company.

April 20.-This being the appointed day for the return of the first sledge from Commander Richards' division, shortly after noon the bamner of the 'Dauntless' was seen, and about $1.30 \mathrm{Mr}$. Grove returned, the bearer of a letter from Commander Richards, reporting all well, in high spirits, and inforning me that all was going on smoothly, no casualtics, and that they had made good forty-five miles against these advcrse gales, which ranged from north to north-north-west, with a temperature not lower than $-27^{\circ}$, it being then $-17^{\circ}$ in the tent where he was writing!

A sledge having been prepared, with ten days' rations, for the conveyance of the despatches to Cape Becher, they were entrusted to the charge of Lieutenant Cheyne, under the 'Victory' bamner. This left me about eight days to complete my arrangements for my cxamination to the north-east, unless intelligence by Dr. Lyall, due on the 2nd of May, should interpose any difficulty. Our artificers were busily engaged re-manufacturing cooking gcar: indeed, every sledge that returns reports something amiss. In time we shall be perfect, but it is really 
disheartening to start for ninety or a hundred days under such apprehensions; not as regards myself, but for those who have already departed.

On the 28th, about 3.30 A.M., Lientenant Cheyne returned, informing me " that he had brought an 'English mail." "The report surprised me. However, a very few mimutes decided that he had made an egregious mistake: he had brought one or two letters and nerrspapers, but the "despatches," as noted in Commander Pullen's note, were left behind. Two packages were elearly indicated. This note of Commander Pullen's puzzled me not a little. Commander Inglefield had arrived in the 'Isabel,' bringing "despatehes and newspapers," copies of which were also deposited at Cape Phillips.

This unfortunate mistake, at such a moment, worried me not a little: but considering that Commander Pullen must be awarc of any material change of orders, and would indicate it in his sealed note to me, I resolved that no orders or despatehes had arrived. However, having given Mr. Cheyne fresh instruetions to retrace his steps, and find the despatehes on the return of Dr. Lyall, I commenced my preparations for the march.

I fully intended to proceed on the evening of the 1st of May, but I was too unwell. Another eause, perhaps, had also some weight in eausing me to delay: I was very anxious to inelude in my last report any intelligence of which Dr. Lyall might be the bearer, and as that officer was also eventually to join my division, I wished to confer with him before starting. I fully expected his arrival carly on the 2nd; our preparations were complete on the 1 st. 
'Londesborough' . . 7 men, 2 ofticers, 40 days' provision.

'Dauntless,' Grove . 7 , 1 , 40 , "

'Enterprise,' Allard . 10 ,, 1 , 50 ,, , 23 men, 1230 rations.

We were also attended by the sledge-boat 'Hamilton,' under the Blanche bamer, two Cape York dogs, and three pups. Our patience being exhausted, at six A.m. on the and we took our departure from the ship, not inaptly termed the "Deserted Village," eleared the Sound, and before noon found the sum, with a temperature between $+3^{\circ}$ and $+6^{\circ}$, unpleasantly oppressive.

The 'Hamilton' was at first attached to the three sledges, but it was subsequently found preferable to attach her solely to the 'Londesborough,' taking reliefs of four men from the other two sledges, as cireumstanees required.

Several seals were noticed on our journey towards Village Point, but all too wary to permit any one to get within shot. Indeed, unless these amimals are instantaneously killed, they preserve such a convenient distance to the hole in the ice, that their dying agonies alone would eause them to slip or wriggle through before they could be secured. As the snow was deep and soft, and the day warm, our sledges, entting deeply into the snow, made but slow progress. I therefore walked on, aceompanied by Messrs. Grove and Allard, reaching Village Point about 2.15. Here we found a large sheet of water, ${ }^{*}$ extending nearly across this narrow strait, and about one mile in length, in which several very inquisi-

* Today the open water was also noticed, extending from the south point of the Sound to Spit Island. 
tive seals were playing, and frequently raising their busts out of water, as if to inquire the cause of our visit. About 4.30 the sledges reached the low point, when we eneamped for the night, the men much blown and fatigned from the effeets of the sum, which already produeed symptoms of snow blindness. It is yet an uncxplained fact, but we found a broad and deeps sledge-mark in the gravel from the cain to the point. Part of the offiecrs and crews of every sledge which had visited this point last season were prescnt, but no one eould recall to mind any sledge taking such an unusual direction, and diagged, too, entirely on gravel : most of them had crossed at right angles; but the rumer width exactly coincided with that of the sledges used last season, and therefore I conclude must liave belonged to our Expedition. At our first encampment the temperature at six P.u. was $+9 \cdot 5^{\circ}$, and the prevailing temperature during the night was about $+15^{\circ}$ in the tent, with $+10^{\circ}$ outside.

About seven A.x. on the 3rd we moved forward; weather not pleasant, but better for travclling: the temperature at starting was $10^{\circ}$. Our object at present being to make the shortest eut over the space examined last season, we steered for the depôt point, passed near to the wreeks of dog and bear, left by Mr. Loncy, of which the rib-timbers were noticed, probably picked by wolves and foxes; and about six, finding that the inshore course would lead us through very rough ice, we pitched for the crening at the south end of Coffin Island, which afforded us most conveniont shelter from the then prevailing wind; the temperature liad fallen to $5^{\circ}$, and at midnight reached zero. Here we eonstructed a cuirm, 
cooked pemmican and tea, and withdrew into our shells. I shall mercly notice one day's routine, to mark our mode of life, or change from that of last season. The pemmican is now so well known that it hardly requires description : however, we had four varieties : the first made with currants, herbs, ete., pounded beef, and suet; another sngared; another plain; another herbs; marked C. H. S. blank. Of this eompound three-quarters of a pound was found sufficient for eaeh person, to which was added one onnce of macearoni, or four ounecs of potatoes, onion powder, sage, ete., ad lib. Of this food I was not fond, and one ounec was enough for me; latterly I avoided it entirely. Our tea was of the best quality. Sleep we lad to provide. The bed, although already deseribed, I shall repeat, is a bag construeted of thick grey felt; this bag is about seven feet in length and three feet in width, allowing a man, when in, to double the top over his face, like a long envelope, and endeavour to suffocate himself by his own heat, until that beeones ineonvenient, when he seeks a breathing hole. This bag, I had almost forgotten to remark, is eovered with a prepared casing of brown holland, supposed to retain the air. It is not easy to enter or cmerge from this bag, especially if the alam of bear, fire, or water, should be given, as the aggregate living mass is covered by another heavy blanket, made fast to the tent-poles at the officer's end of the tent, to kecp lim down until the rest escape : he is also plaeed at the weather or extreme end, to keep the eold out, as the place d'honneur; and to shield him, a further strip of this brown holland, furnished with pockets, to place small articles in safety, affords further protection from 
the picrcing wind. But to the main protcction between the snow, ice, or cold gravel, and the body: the "feathicrs" (Macadamized bits) being removed, a Mackintosh cloth covers the flooring; on this is spread a blanket of buffalo skin, but this also was meagre; frequent wet causcd the hair to takc lcave and entcr the cookery, and evcntually, until indignantly turned out, it was reduced ncarly to spottcd parchment!

It is almost needless to excite the sympathics of those who can soundly sleep on the roughest gravcl, or piles of shot, and whose bony projections arc calculated to withstand any inconvenicncc; but, pour noi-méme, I am getting tculer, and I fecl the difference betwecn true and fictitious feathers; and the cold, which at first chose to make my dorsal column its immediatc point of attack, was very scnsibly felt; but layers of non-conductors eventually remedied this : habit too (like the eels) inures one to suffering. 'I'cnt discipline continucd: at a ccrtain hour the cook is called : I never knew a cook call himself. Why should thcy sleep morc than any other member? sceing that they have the samc time allowed, and change daily : probably the last cook being the vcry foremost to call his successor to a sense of his duty. Our fires werc candles, thcrefore soon lighted; but the cook had to procure his snow and thaw it, before he obtained watcr. When this conld be conxed to boil, the chocolate was put in, and the word passed, "Cocoa ready." Hcads emerged, pannikins produced (tin-pots holding just measure one pint and more each person), biscuit is scrved out, and breakfast soon despatched; no waiters to pay, no chambernaids. 'The lunchcon-grog is 
mixed with the water from remaining fire (now available): luneheon put into the "seran-bagg," and "Down housebreak up!" Sueh, reader, is the delightful proeess of the Polar travelling gentlemen, to be understood in future as "started" = after breakfast, ete.; "pitehed" = or ereeted tents, eooked, and went to sleep.

On the 4th of May, at seven, moved forward for Star Bluff, but heavy paeked iee-fragments of broken floe, eemented together by frost--(only to be eompared with the roughest roeky travelling over disrupted quarries) rendered our progress difficult with our heavily laden sledges; we were very glad to "piteh" five miles short of it,

About eight 4.M. on the 5th we moved forward, and on elosing Star Bluff we found the iee beeoming vcry tender. I thought that the off-shore iee would prove firmer: it was so, but I did not go suffieiently far, and in the attempt to make a short eut, to avoid one of the most apparently dangerous spots, the leading sledge broke in. Ilere the trusty 'IImilton' did good serviee; she was soon floating beside the sledge, and safely were the goods transferred. The instruments were safe, and I was on the point, earrying the theodolite-legs in my hand, of seeking a seeure spot, when I found myself suddenly immersed in a bath, by no means aeeeptable: it miglit hare been an intentional interpretation of C. B., but it was beyond joke. The eurrent beneath the ice ran very strong. I had the ehronometer on me, and, unless I was soon resened, I should be missing under the ice! At present the legs of the instrmment aeross the loole sustained me just enough out of water to pre- 
vent wetting the ehronometer. A traek-belt thrown to me, and eonneeted with others, - for it was dangerous to appronel me,--soon dragged me out like a walrus, and all was right. The present condition and safety of our wardrobes being a matter of considerable doubt, Mr. Grove most kindly clothed my lower extremities until mattcrs were aceommodated. Our only loss was ninetysix pounds of bread and some pretty considerable dampnesses. The gutta-pereha cases for brcad proved too brittle, and split; they are ecrtainly not adapted to the rough handling of seamen: no man who eannot understand (and feel for) them should be entrusted with, or ean derive advantage from them; they will not stand rough usage. The bread thus damaged was buried, and a earn erected to mark the spot, so that, if distress required us to fall baek upon it, we knew where it was deposited. But many of my readers would doubtless like to know how I relished this cold batll. I will deseribe it in a few words. The mexpeeted immersion was not pleasant: when in for it, I eared little about it, but the tide and safety of ehronometer did not allow me to enjoy it: the eold was not felt, but a glowing sensation prevailed until I reeovered my eustomary dry elothing. Moving forward towards Star Bluff, we pitehed about seven that evening off it; but the ice proved too heavy to allow us to pass to the land.

On the 6th we pushed forward for the depôt established by Mr. Loney, but failed in reaeling it by two miles; but on the 7 th we suceeded in time to make it a rating position for the elronometers. Here we obtained the latitude and other important observations; 
made good our deficiency of provisions from the depôt ; anp last, not least, rested six hours. At this station a wolf came to inquire the cause of our visit: it was joined by the dogs of our party, and did not quarrel; but the animal was so unlike a wolf, and, supposing our Cape York dogs a little blanched, the extraordinary similarity of the remaining black lines so much interested me, that I issued orders for his "tabu," under a feeling that it might possibly be one of Sir John Franklin's dogs, and by petting would conduct us to some clue as to his peoplc, or, even failing in that, to some tribe of wandcring Esquimaux (Huskies is the only term used here). Thic bears had visited the cache, torn down the blue flag, but without disturbing the staff or the provision! Funny fellows they are! Why have tney such an antipatly to blue? Yellow is safe; possibly they fear pratique, as many bears did not unany ycars since; but to lave climbed this loose gravel pile, stood on lind legs, torn down the flag, and rent it as they did, is marvellous. Their general wcight is about seven hundredweight; my own weight about one and a half, and yet I found it difficult to retain my footing on such a moving pile : they must be fairies! About eight P.M. we pitched two miles sloort of a low gravel point, having in sight the new island seen from Exmouth Island on the 2Sth of August last; distance six miles, the temperature $+4^{\circ}$.

May 8.-On the 8th the division moved forward about seven, but about eleven I remained behind with the 'Hamilton,' Mr. Loney, and two hands, to secure the latitude and other observations on a low intervening gravel island. This island is composed, as all here are, 
of rubbly Macadamized magnesian limestone, abounding in fragments of fossils, seattcred in every direetion, principally Terebratulæ, Pectens, and Madreporites. At this position the valuc of our sledge-boat 'Hamilton' was practically evineed : our party had gained a start of at lcast two miles; thcy were under canvas; we made sail, and with two men, two dogs, Mr. Loney, and self steadying the boat, overtook the sledges with ease, at least two miles alead, in the lapse of two hours. About six we pitcled on the northern spit of the island, ascended its ligh-turreted peak, built a eonspicuous cairn, and, this being the first important discovery and keystone of our opcrations this season, hoisted the Union and took possession, under the customary forms, of Princess Royal Island. At the base, with a temperature of $+6^{\circ}$, the eold was felt sensibly; but as we reached the summit it becamc softer, and eventually comfortable. Those who deal with cold metal instruments, peneil and paper, appreeiate these changes very sensibly: I consider $l^{\circ}$ in the value of wind here to be equal to $-10^{\circ}$ on the previous temperature.

This was Sunday. Our motions by day interfering mueh with our present mode of travelling, the eustomary observance was deferred until evening, when all hands were eollected in my tent. These are matters of discipline. It is not my intention to inform my readers, or rather to trouble them, with the question of how good or bad we were, but possibly we may be found to Him who knows our secrets, quite as good as "the tinkling bells." In few words, and to the point, I merely observe, Let the rcader peruse the incidents of this Work, and 
ask, "Had we not cause to think deeply, and exclaim, "If the Lord himself had not becn on our side?"

May 9.-(Temp. $2^{\circ}$.) On the low northern point of this island we deposited our surplus provision, leather boots, and every useless article of hamper which had been unfortumately, but stcalthily, crammed upon the sledges, giving the crews some additional hundreds of weight not cstimated in the two hundred pounds per man. My previous arrangement had contemplated the return of Mr. Allard from the depôt; but, having re-victualled his sledge there, we again moved forward, taking him five days further. I think I hear my good old frieud, Sir W. N., exclaining, "That confounded racehorse spirit!" etc. Well, be it so: the thought of what one once could do often impels a man forward: I thought ny strength would enable me to return without asking any one to drag me, and in this I was not deceived. Our new friend, the wolf, still hung upon our rear, but not disposed to make friends, or quarrel, with our Cape York dogs: its labits arc certainly very peculiar; it cares not for us, and frequently approached so near that it might have becn shot; but it is tabu. Sailors are decmed superstitions,-granted; but let reason have its course. 'T'he canine species has not unfrequently put the biped to the blush. What sensible apology is there for shooting this, at prescnt, harmless benst? and yct, by good fortune, or providentially, if but a dog escape to savage life (and those we have are but wolves), it may yet lead us to the last resting-place of his beloved master! Why then commit a mere wanton act of cruelty? The Queen orders lie shall live! 
Our course is now dirceted to a low point to the castsouth-east, surmounted by a very remarkable momit, about a mile and a half within. 'The included segment between this and the outer point of Princess Royal Island forms a deep bay, evidently much cut up by numerous strcamlets, flowing from extcnsive lakes, converting the cutire space, if thawed, into one inmmense series of flats, mostly even with the surface: there is therefore at present no elance of sinking into this " luud flat floc." Upon this line of mischief, as all sloal lines are ("dangers" hydrographic), the pack ice was of course compelled to observe "the rules," and within it we obtained smooth, but, when cracked, slightly impeded, travelling. But to make this matter clear, and to mark this species of travel, it is requisite to bear in mind, that notwithstanding the incomprehensible masses of floe-ice which cover the Polar Sea as with a mere tablecloth of varied fabric, coarse or fine,- - that the great laws of nature, the tidal influences, camnot be arrested. The huge floe must obey the law of floatation: it riscs, cracks, falls possibly below, or is supported by some interposed substance above, the so-called land-floe, which refuses to move (possibly in our case because it camnot); is frozen to the bottom: a gap is left, filled in with light snow, and one very fatal to sledge l'ummers, and uncomfortable to those who have no serviccable legs left, by finding the hips nearly cugulfed in these cracks,-chasms more properly. It is therefore advisable to keep inside thesc traps, and rather observe the parallel contour of the land, or where the ice is solid, than to contend for short cuts over hummocky ice or frozen pack. I have thus

VOL. 1. 
far travelled out of my road to explain fully the nature of the sealed liydrography of thesc regions, as well as to explain that Nature will exert her undoubted rights at the Equator as well as the Pole itself! On the power philosophieal I need not dilate: the laws are too simple. I have stated its winter muisanee; add to this, for summer, the diffienlty of lauding, by reason of interposed bands of water ncar the beach, where the sun aets on the dark-coloured mass of the lills and beach, eausing the water to flow freely between, long before the tableeloth can be pierced.

At our noon lunehcon position we erected a snow pyramid, and, as it was not convenient to lave it disturbed by bears, left a eomposing dose for Bruin, in the event of his revisiting this spot, his tracks being numerous just here: it is to be loped the wolf will not taste it ! Thinking of Ursus maritimus and the original astronomers, who plaeed Ursa Major and her eub at the Pole? It argues a knowledge that we camnot understand : it is the only true representative of the Polar bear! Is this "the sweet little cherub"? As one of our family mottoes is "Bear and For-Bear," I shall be silent.

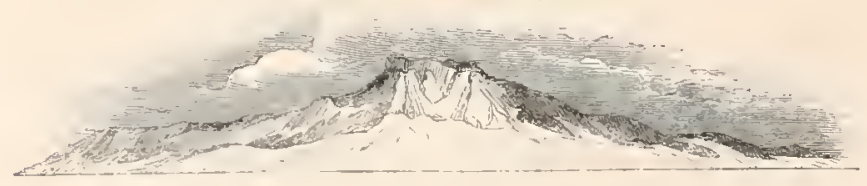

PRIXCESS ROYAL ISLAND: N.N.W. FIVE MILES.

May 10.-Morning fine, but hazy; temperature $6^{\circ}$. Wolf hovering; men eomplaining of sore eyes, resulting 
from the sun's glare: doctor's shop opened, and various remedies applied-vimum opii, glycerinc, tea-leaves, tobacco, etc. Each seemed to lave his favouritc remedy, and as there was no really bad case, it was as well to let them have their run of humour: for my own part, I was satisfied that a more lenient mixture of the vinum opii was preferable. Example docs wonders: I established the daily wash of ten drops in a tablespoonful of water, and I never had to apply the raw material again. As my duties with sextant and theodolite brought me into more direct collision with the sum, and I did not suffer, my men soon found that the Captain's remedy was perhaps the best; and gratefully they afterwards accepted the wash as I passed it round, giving each man his strip of lint or bandage wherewith to bathe his eyes before he entered upon his delicious dreams of deer, musk-ox, hares, or ptarmigan, of which he was, as it resulted, never to taste!

May 11.-About cight we moved forward; heavy work, warm sun, and pack-ice. As we gradually neared what we imagined to be the smooth floe, we at length perceived that we had ascended considerably above the sea-level, and after moving forward about five hundred yards, crossed over the low point which we had seen from Princess Royal Island; and thus, the labour being over, very much to the satisfaction of our crew, having done a heavy day's work, "pitched" before noon. The ascent of our hill, having no weights and a chance of game, was merc amusement: but our delay here was important. The view from the summit enabled me to save hours, nay days, of conjecturc; it furnished the groundwork 
of weeks' labour, earried out by the knowledge of what must be the realization of the then radius of vision : it was one of those bright days whieh are to be made the most of in these regions, of which I was not slow in taking advantage. In eompliment to one of my most respeeted friends, the senior naval Lord of the Admiralty, I named this Mount Parker. 'The few hours' delay here repaid me abundantly: I had laid in a stoek of matter to guide me strietly for many days. I was enabled, by our astronomieal data, to impress the indelible seal of truth on all I had done, and by that truth to be aided in fixing beyond dispute, so long as sun and latitude eontinued available, many other important positions from which I might merely see this! So far the surveyor is strong in his position: he ean eombat opposition, simply by faets and observations, whieh the most talented ean but verify; and eventually ean afford to make a long stride and overtake his poor friend the tortoise or hare, driven perlaps by impulse, but eertainly not by sagaeity, to despise the truths of seience, to the aeeomplishment of umproved, and not well-searehed distance. The delay here enabled me also to put in praetice what I had some days contemplated, viz. ehanging the travelling hours from day to might: that is, the men enjoyed their repose or sleep during the warm temperature by day, when exposure to the sun was oppressive and withering, eommeneing work at six P.M., lunehing at midnight, and ending at six A.M.; the sun however, although at very low altitudes, being always visible, if not veiled by elouds, ete.

On our deseent from Mount Parker we notieed the 
deposits of lare, ptarmigan, and fox were abundant; and following a traek whieh I supposed might lead to their launt, most unexpeetedly stumbled upon some bones of great size projeeting from the earth, which, on eloser examination, proved to be the liead and probably the entire skeleton of a very large whale, imbedded at a height of not less than five liundred feet above the sea. I endeavoured to detach one of the ribs, but it was too firmly frozen to yield to our pieks; a portion of the head-bone was broken away and preserved.* About eight in the evening we moved forward, steering for a long, low spit, bearing east-south-east, barely visible from Mount Parker, owing to the diffienlty of distinguisling any slight rise of snow-eovered land; the weather also now inclined to sleet, which to us is quite as annoying as $f \circ g$.

May 12.-Shortly after midnight we erossed many tracks of bears, and about five o'elock Ursa Major and Minor made their appearanee, trotting down very leisurely, mistaking us, no doubt, for tliree fine wallus: the train was stopped, and all but the guards desired to lie down and keep elose; the enemy still eoming on very leisurely, but evidently not at ease, ever and anon casting her blaek-tipped nose aloft, looking over her sloulder, and sniffing at something not pertaining to us. Malheureusement, the wolf now showed himself, and just as we eonsidered our game eertain, made a feint in rear, spoiling all. Mamma was quite on the alert, and intent to save her eub: off they went at a eanter. Our

* It was then charged with oil; it has since been deposited at the Roval College of Surgeons. 
five dogs were slipped, and the young men of the party followed up the hunt. Gallantly did the dogs behave, the wolf acting in eoneert: and at a most eritical moment, when Puneh (our Punch) was making a determined assault on the eub, mamma put her paw on him! All was breathless suspense, for this was our pet. At this instant the wolf proved his superior taeties by attacking Madam in rear, when Punch was released, and eseaped, not much damaged: but he was not eowed, and proved himself a fine, eourageous animal. One or two ineffeetual shots were fired, and the party returned, when we renewed our journey, eneamping at seven A.M. on a low spit, probably a-wash, if free from iee. The loss of one of the bears was mmeh felt, our stoek of food for the dogs being now nearly gone; however, from the number of traeks, we expeet soon to have more of their society. The ehange of travelling time entails on me the duty of watehing the sun from nine A.M. until near three P.M., but does not eall for any assistant; temperature at noon $44^{\circ}$. Before starting this evening I determined on depositing the 'Hamilton' on this point, as affording the most eonvenient spot for sea operations, should her serviees be required; and as our route now seemed to promise an almost direet jommey along the land to Jones's Sound, it was not probable that we shonld require her aid until it beeame neeessary to make further examination of North Cornwall in July next. Here also were deposited the return rations of five days, in iron-bound easks, for eneh of the two long-joumey sledges, 'Londesborough' and 'Dauntless.' A very considerable pile was eonstructed of the surrounding frozen 
turf, and above this the boat was inverted, with her mast reversed or stepped on her keel by our mode of rig, and a large blue flag hoisted to mark this as another of our fixed stations in the survey, to which the name of Hamilton depôt was given.

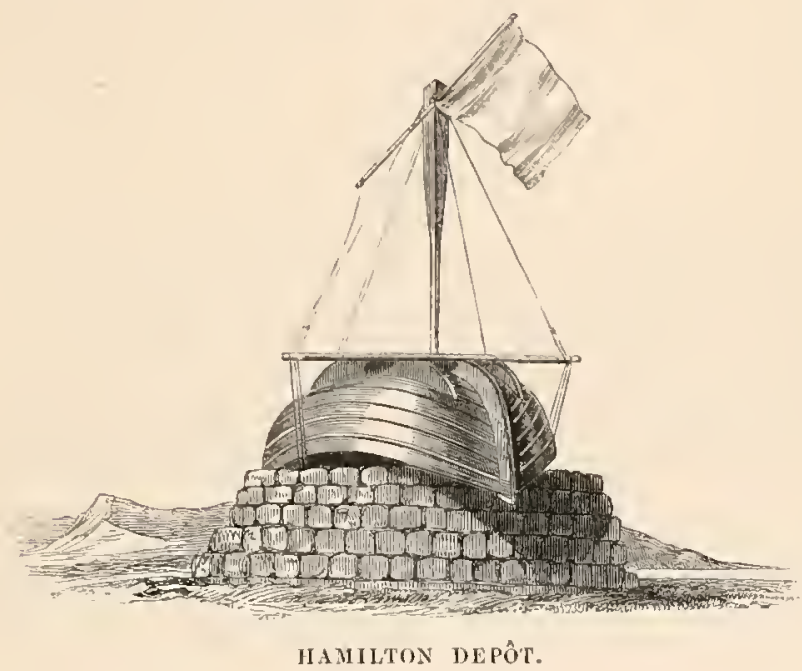




\section{CHAPTER XI.}

Inconvenient elevation.-Cape Disraeli.-Imbedded Thale.-Departure of Mr. Allard.-Determination of speed.-Strait discovered.Progress arrested by the l'ack.-Snow Crystals.-Discorer open water.-Overland Mareh,- l'rogress bared.-Fossil Station.-Deep Soundings.--Pack Ice.-A hollow Cain.-Cape Disappointment.Wellington Channcl.-Apparent Graves.-Piteh Mount.-Bears.

Tirkse arrangements complete, at six P.M. (temp. $5^{\circ}$ ) we moved forward, intending, as the weathcr proved liazy, to adhere to the tidal or land-floc crack, which would sccurely, although cirenitously, lead us to our next position; but we were again most deceitfully led into another ascent, until we suddenly discovered, through the momentary cessation of drift, that we had upon this occasion rather a steepish declivity ahead, and that we had arrived at an clevation of at least eighty feet above the level; and yet our men at the drag-belts had not discovered the increased labour due to the ascent! Until we fairly asccrtained onr position further progress might entail unnecessary labour, as, from the distance traversed, we computed that we could not be two hours' march from our next important station; we therefore eneamped, and shortly after, on the cessation of snow, noticed, abont 
four miles east-soutl-east, the remarkable jutting headland scen from Mount Parker: our delay was fortumate, and saved much labour, and possibly the destruetion of the sledges.

May 13.-At noon the weather was fine, moderately clear, and warm, with the temperature at $20^{\circ}$; latitude, $76^{\circ} 44^{\prime} \mathrm{N}$. At eight, with a temperature of $+5^{\circ}$, we moved forward. Our course now lay down-hill, for the nearest floe-edge (luckily a frozen swamp or pool) beeame available, which led us out of our dilemma by its outlet to the sea, and before midnight we were encamped at the base of the remarkable headland before noticed. $\mathrm{Mr}$. Allard was now ordered to complete our two sledges to forty days each, and return to the ship, replenishing at the back depôts up to Princess Royal Island; on his return from the ship, accompanied by Dr. Lyall and his ten-mon sledge, he was to bring up the whale-boat, should open water render any such step advisable. Our party ascended the mount, elevated about eight hundred feet above the sea, from whence our immediate course and future operations would be determined. This was a critical position, involving perhaps our ultimate success or faihure in reaching Jones's Sound. We had now lessened our latitude to $76^{\circ} 41^{\prime} 30^{\prime \prime} \mathrm{N}$., ten miles south of the ship's position; and here we had reached an angle, dividing two lines of advance. A wide, capacions chamel invited to the soutl, possibly tuming, beyond the points in view, westerly or easterly, but clearly to my mind not a navigable sea; it niight lead to Jones's Sound, but "the great object of oul' seareh" was over" navigable seas, and where any party escaping would in- 
fallibly lcave somc sign. The other course was due cast, seen, it is truc, by myself only, almost as a drean, but so doubtfully and indistinctly to the naked eycs of others as not quite to satisfy them; but there is no accounting for sight. Now it should be rccollceted that my sight was assisted by a theodolite and good telescope, through which no onc clse cared to look. I had scen enough to satisfy my mind. Onr cairn was built, the territory duly taken possession of, and, as this sack was to be duly kept until my return, I thought it but prudent that the Chancellor of the Exchequer should seal it; it was therefore named Cape Disraeli. On our ascent two ptarmigan wcre fircd at, but the gun was bad and I missed killing, but wounded one, which probably was enjoyed by some fox.

Mray 14.-On our desecnt we again met with another imbedded whale, and at about the same elevation. Our position at noon placed us in $76^{\circ} 4 \mathrm{l}^{\prime} \mathrm{N}$. and about $91^{\circ}$ $30^{\prime} \mathrm{W}$., as yet to the west of Cape Hogarth, and only twenty-ninc miles north of that position: I could not therefore afford dclay here, without anything offering beyond following up land traces by this channcl, nor could I venture to move finther soutlicrly; yet I felt very uncasy at leaving this strait unscarched.

At noon the sun shonc out powerfully, and dispelled some of the snow-charged vapours lianging over the ontline; and yet the thermometcr did not rise above $15^{\circ}$, and only $44^{\circ}$ in the tent. All were absorbed in deep sleep, when suddenly, in the far east, two resplendent white caps (distant, I found, thirty-six miles) revcaled themselves, marking out the gates of our chamnel. An indeseribable sensation pervaded me: I sang out, as Colunn- 
bus no doubt did to his friends, "Master" (Mr. Loney,) I have it." "What, Sir?" "The key of Jones's Sound." Sneh it proved. A snore, and all again was silence. I continued mcasuring base, taking angles, ete, to determine the importanee of Cape Disraeli as to height, ete., whieh resulted in eight humdrcd and forty feet; but sleep I found impraetieable.

Abont six P.M. the sledges werc paeked; Mr. Allard reeeived his instructions to a particular day, then very doubtful (and not intended), when we were to meet again at Prineess Royal Island: under the customary checrs, with banners displayed, we parted on opposite eourses.

Our journey, through a dense and almost impraeticable paek, became very diffieult, rendering it neeessary to double-man our sledges by spells, and eventually we emerged on the eomparative smooth floe, having aeeomplished about half a mile in four hours. At midnight the temperature fell to $-5^{\circ}$. Our wolf deserted us, r'eturning, I believe, with Mr. Allard, who took away three dogs: a she-bear and eub, worried by a wolf, were notieed at a great distanee, and avoided us.

'The morning of the 15 th was brilliant; we eneamped at seven A.m., after a laborious day. All the distant land was enveloped in haze, and previous exeitcment, added to some degree of fatigue, had indueed me to sleep, so that I got up too late to eateh the sum at noon: I was however very eontent to enjoy alone and undisturbed the seenery whieh about that moment beeame mneiled, and, aided by sun and several of my well-fixed landmarks, I was enabled to prune the const-line of any 
chanee errors. We breakfasted at four, this being Sunday, and at six P.M., after prayers, with a temperature of $7^{\circ}$, moved forward. The floe had now beeome uniformly smooth and elear of hummoeks. Hitherto the rate of travel had been estimated, the efforts were irregular, and resting periods undetermined : this did not suit me. I travel always, for years past, with reels of the strongest eable-laid sewing-eotton, eapable of sustaining fair weights -fourteen pounds: these I liad measured before leaving the ship, and they were found to be very eorreet in length, viz. one hundred fathoms (it is markerl, Patent line, two hundred yards) : of this line I brought eigliteen reels, equal to eighteen hundred fathoms: some had been rewound on a eore, with the rumning part from the eentre, as eustomary in groecrs' shops, ete., whieh prevented any chanee of undue twist. These lines were intended for sounding in great deptlis; and the entire loss of the line proved but a eheap mode of purehasing a valuable faet, for the failure of finding bottom in great depths is valuable information.

May 16.-Naking use of one hundred fathoms and the ehronometer, on the prineiple of the log, I was enabled to determine the period at whieh the sledge moved over six hundred feet of snow ; the result, at very slow travelling, gave one mile in forty minutes. As this was casy work, I enaeted that eaeh spell should oceupy forty minutes, and an interval for rest of ten minutes, seeuring a mean value of one mile in every fifty minutes of travelling; thus, in a eomplete day, we had, from six p.u. till midnight, six hours, —one hour for luneheon, smoking, ete., and five homrs, up to six A.m., making together 
eleven hours, or 13.2 miles. I considered that eight miles was a fair mean, and fifteen an exeited, journey; but on the thind day from quitting Cape Disraeli we had made good, notwitlıstanding the heavy difficulties attending our starting, thirty-six geograplic miles.

In the first instance I thought forty minutes might be deemed a long spell, but I soon ascertained that frequently, our time-bearer being ahead pieking the road, and his signal munoticed, that fifty-six mimutes or more stole away impereeptibly. Of this however I seldom failed to learn, after pitching, by some dry remark from some of the party; they always faneied they had achieved at least fifteen miles. The reflected rays of the sun between midnight and six A.M. being principally in our faces, eaused much ineonvenience to the eyes, and retarded the morning's work considerably.

May 17.-The latter part of our journey has been through rough and hummoeky ice. About midnight we lunehed near the first seal-hole we lad noticed since passing Star Bluff Bath; about six A.м. we encamped on the smooth floe, but the weather was too thick to distinguish any objects but our two friends, the direetion bluffs (Capes Derby and Stanley), distant about five miles south-east. 'The temperature had now risen to $15^{\circ}$.

On eoming out at noon to obtain the latitude, the fog had dispersed, revealing to me a most interesting channel, inviting our entry: the main road was here clearly delineated, and studded on either side by noble, beetling cliffs, each cxhibiting a similar dark belt of stratification above the line of débris, affording, to me at least, a nobler and more acceptable view than any vista of palaces. 
In the distanee, where several ranges of intrusive hummoeks interfered with the observations I wished to obtain, I eonld perecive similar high, golden-tinted eliffs, just showing like gems above the horizon, of a bright flame-eolour, but between them and the north land a clear gap slowed the distant and fiee lorizon. As I stood alone, all my party loeked in sleep, I felt the sullen grandcur of the seene, and looked forward, with no eommon feeling of interest, to place the eolours of our Queen on those bright speeks! As to disturbing my eompanions, it was useless; they would soon see enough of it, and possibly might not be over-grateful for breaking in upon some pleasant dream of vcry different objeets. Within our grasp the accomplishment at least of this quastio vexata appeared, to my anxions mind, eertain; everything seemed to be in our favour,-provision, men, and high spirits; I therefore went to my bag! Our latitude was to a seeond the same as that observed undcr Cape Disraeli, making our eourse hither, due east, thirty-six geographie miles.

May 17.-Temp. 22․ About scven P.M. we moved forward: I had a strong inclination to take the northem shore, at all events until I eould gain a good elevation from whenee to see my way in advance." Strange impulse! We had reaehed more tham mid-ehamnel, and had lunehed at the furthest limit on the floe from whenee I eould eommand the stations on eaeh side, as well as the distant land. Here wo were arrested by an impraetieable, heavy, and very high pack: our only resource

* It was this station which serred to fix all the distant objects casterly. 



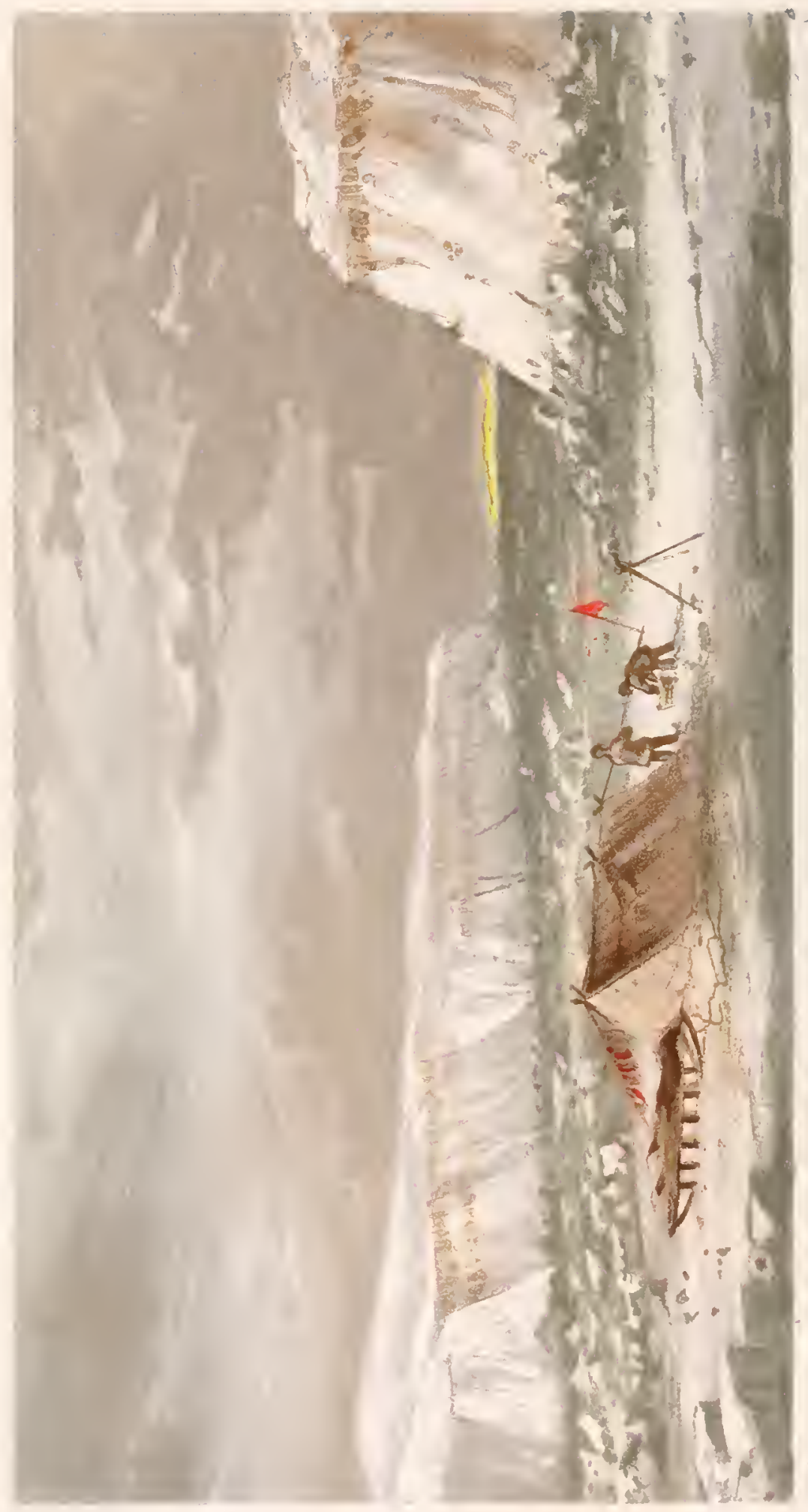


was the southern sidc, and that scarcely afforded adrance. The entire chamncl appeared to be pressed home with heavy pack, and suspicious withal. Water, a stranger to us for some time, might be scen in the holes; the very cliffs themselves, frowning on either side, with their dark stratified upper features, scemed calmly to deride our cfforts to penetrate these mystcrious recesses.

May 15. - While we delaycd it began to snow. IVe had long joked on the different forms in which these erystallized particles fell, and lad classed them into favourable, harmless, and unfavourable. We have to deal with the farourable, or that which, falling in large, beantifully formed crystals, in thcir most claborate degree of finish, I lad termed "stars and garters," from their similarity to the star of that Order, excepting that it has eight rays, whereas Nature only gives six. It now snowed "stars and garters." Seamen are a little superstitious. I seized this as a favourable omen, and pushed for the southern shore, landing about six, when the sum shone brightly, and we obtaincd our time, etc. but it soon resumed harmless snow. I succeeded in obtaining the latitude, placing this now land in $76^{\circ} 38^{\prime} 21^{\prime \prime}$ north; and taking possession in due form, named our direction heads Capes Derby and Stanley, and the territory North Yorkshire. The position abounding in fossil limestone, chiefly of the Derbyshire marble, with Entrochi, Terebratula, etc., obtained the name of "Fossil Station." At seven P.M. we pushed forward, skirting the tidal crack: but our work was not pleasant; the evening less so, owing to a south gale brewing, which, concentrated into this pipe of the chamnel funnel, would perhaps 
cause us to lose a day. And yet how fortunate have we been-never delayed an hour by weather! We followed our course under the base of these beetling eliffs, shooting their débris into the sea (when unfrozen). The strip available for travelling was at times redueed to sueh a very steep ineline of drift snow, that we were eompelled to take to the rough ice. In our mareh round the base of the eliffs one ptarmigan was seen, and Mr. Grove killed a small harc.

May 19.-About four A.M. our further progress was arrested by the dense and impenctrable pack up to the eliffs: off-shore it proved still more disheartening; had

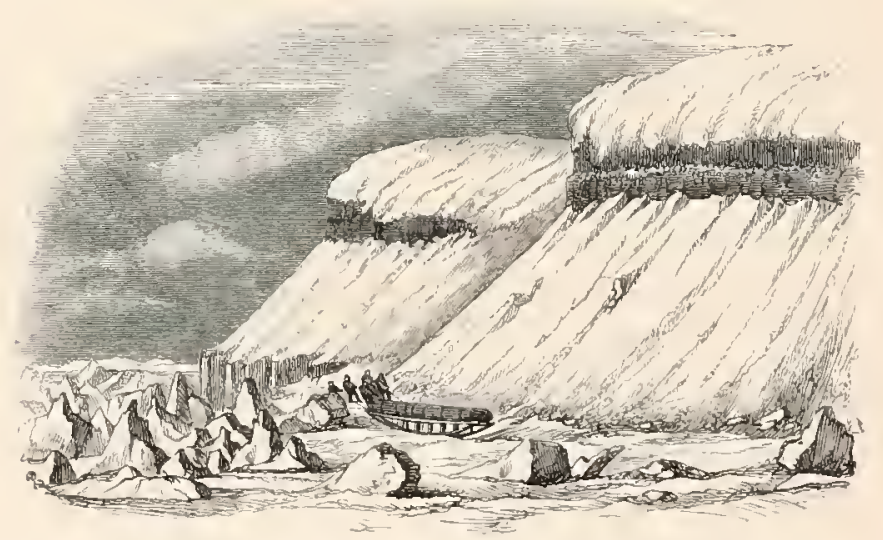

it been merely iee, through which we eould have ent our way, the matter would have been simply one of labour. Mr. Loney advaneed to reconnoitre, but the result of his report decidedly elosed further speculation: the water had made between! The glaeier, abruptly broken off in advanee, was sea-washed, and the ehamnel cxhibited unmistakable evidence of breaking up! 
The only alternative remaining was to pitch our tents, and decide on making the most of our position. I was not yet quite couvinced that we might not, by sacrifieing a little of that precious article-time, convey one sledge ovcrland until we met the floe agnin, and, leaving the 'Dauntless' party here, proceed alone with the 'Londesborough.' 'Tlhoughts and orders follow in rapid sueeession. Our arrangements were eomplete by nine P.M., and the weather having changed, the double party werc in marelı "over the hills" in high spirits, carrying one tent, sleeping bags, and provision for five days : if any prospeet of success promised, the party would return for a sledge and further provision. This was a clange, a cheerful cliange, too, from our dilemma, - and what is not to well-disposed men?-and we had the pickings of a very fine erew, relieving some of those likely to suffer from the crew of the 'Enterprise.'

About noon we lunched on Victoria Peak, North Yorkshire, elevated about fifteen hundred feet or more above the sea, enlivened by a benutiful midnight sum, clear, and temperature $18^{\circ}$. But our fate was deeided: not only open water from shore to shore, close up to our late cncampment, prevailed, but the entire sea, easterly as well as northerly, was navigable, streaked only by sailing ice. But although checked for' a time in this direetion, from this elevation other objects for 'Hope' and 'Enterprise' discovercd themselves: north-westerly new islands showed out, and afforded reason to hope, disappointed as we must feel in not plaeing the eonfirmatory cylinder on Austin's cairn, or exchanging ours for it in Jones's Sound, that we saw its commanding VOI. I. 
hcadland, and had now the prospcet of adding further lands to Her Majesty's Polar territorics in the northwest. But we had not yet finished; the furthest available station must be reached, and the colours planted on the eastern head of this new strait.

Mray 20. - At seven A.M. (temp. $20^{\circ}$ ) we reaehed the bounding cliff, possibly fifteen lundred feet above the sea, which was named, in compliment to one of our banner ladics, Britannia Cliffs: beyond this, advance was absurd, but not impracticable for possibly three miles, but only to descend to the floe, and reasecnd with loss of strength, ete. I detcrmined therefore to be contcnt with my position, and make good my ground, preferring complctc observations to any puerile attcmpt at enlarging my "streak upon paper" at the expense of want of verification (English, truth). We surveyors know the value of "taking time by the forelock:" that only could indelibly establish our furthest, as well as the position of the extreme land in sight.

Hcre we stood on this noble headland on the 20th of May, in a bright, warm sun, in latitude $76^{\circ} 30^{\prime} 42^{\prime \prime}$ nortll, and eastward of $90^{\circ} \mathrm{rcst}$, with an open navigable sca below us: yes! the "Polar Sca," for anght any man knows to the contrary, bencath us; to the soutli-castward several large arms, or inland rivers of some cxtent, penetrating, even visibly to us, decply into the land, forming probably other islets, and connceting crentually with Jones's Strait or Sound. On this barc, bleak mountain, having obtained all that was requircd, I at length went to slcep, and for the first time probably disappointment and fatigne rendered my nap sound. The land on the op- 
posite side of this strait was clearly an island, to which I gave the name of North Kent, and to the south-easterm conspicuous eape, Prince Edward's Cape; the remaining: remarkable extremes I leave for Her Majesty's pleasure.

May 21.-After building a large stone eairn, having placed others on four different lills, and deposited the enstomary leeords, we strnek our tent at nine P.u. (temp. $20^{\circ}$ ), and, retracing our steps, reaehed our rendezvous about three A.M.; made coffee to reeruit the men, and then moved westerly to obtain a more sheltered position for repose. During our absenee, a hear had been noticed sauntering about the bay, but, even with one man in charge, did not approale the tent. We were much deceived in the distanee, and when we pitehed, 'Dauntless' was at least two miles behind. At noon I was the only unfortunate gazing at the sum. I found here a splinter, or cortical layer, of a pinc-tree, not aged. Waiting until ten P.M, for 'Dauntless,' we moved forward, reaching our old eneampment at Fossil Station about 1.30, where we pitelied: the weather now became cold, attended with sleet and bad-omened snow. About three the 'Damtless' rejoined, and, the weather' having improved, we aseended the eommanding height near Cape Derby, in the hope of being able to make out (being fifteen miles nearer) onr new islands to the northwest. The temperature was $14^{\circ}$, but bitter eold from the south-east, and the driving snow, just before we gained the summit, destroyed every prospeet. This mountain, mulike any we have seen, is eomposed near its summit of grauwacke slate, of whieh, as it furnished noble building slabs, we eonstrueted our cainns. On our return to the 
tent we found the weather perfeetly mild. Since our last visit the snow liad nearly disappeared, and revealed five circles of stones, marking probably the resting-places of Esquimaux, but rery old : they conld never have occurred there by any freak of Nature. Our place of cncampment was also a strange accumulation of fossiliferous rounded rocks. This position afforded us the first opportunity of determining the rates of our chronometers, which appear to have behaved well; one being my own, well tried for twenty-three years, I knew the value of, but the other belonged to Government.

At seven P.M. we moved forward against a cold, bleak, north-west breeze, and about midnight fell upon our outward track, and lunclied at one of our former stations, near the seal-hole. Such an opportunity was too valuable to lose, and I here tried for soundings in the sealhole with a two-pound lump of lead, and the cottons (to which I liave alrcady alluded): four reels rapidly vanislied, but no bottom, with four hundred fathoms in the strait. The current was found to set very strong to the west (true).

Abont six A.M. on the 23 rd we pitched about two miles in advance of one of our late bivonacks. The sun again lent his eheering rays, but, "after recent exposures," attended by unmistakable appearances of thaw in the strait, not unattended by the drawbaek that it might break up the pack before we reached Cape Disracli, I possibly was not so grateful for his presenee as I might have felt at any other period. Breaking up " the pack" and breaking up "the floe" are so widely distinet, that I think some explanation is needed; in few words, there- 
fore, the floe is a homogeneous frozen mass, of possibly miles in extent, averaging from three feet to three feet six inches, or four feet, in thickness; it is tough, elastie, not easily upset, and impermeable to the sea; but the paek, being but a colleetion of bits of floe, or bay ice, broken into piees of every size and in every imaginable idea of confusion, at one place two feet, at another twenty ol' thirty, and only eemented by easual freezing, tumbles asmonder by its own inequality of weight, rending the heavier from the lighter by any slight aceess of temperature, or still more vigorously by eracking and letting the rarmer sea-at this period never below $295^{\circ}$ - flow in between the joinings. Such a body of iee is at all times suspieious; we look npon it in the light of sedition in the eamp, and ealeulate pretty eorreetly that the spring will relieve us of such rubbish when we ean ent through the simple three-feet iee and persuade it to float out of our way.

On the 25tll, being then near to the entrance of the southern lead from Cape Disraeli, I moved towards the eastern peninsula, in order to ereet a beacon, direeting the 'Dauntless' to piteh on our' old outward traek, near' the paek, and await my regaining. Our tent was pitehed about a mile from the shore, at the verge of the rough ice, from whenee we walked to the shore, aseending the erest of a very remarkable little peninsula, forming a deep bay within it to the southward: from hence I saw down the throat of this strait, nearly due south, but it ras too hazy to obtain any satisfaetory elue. Construeting a substantial roeky pile, of five feet base by eight feet four inelies in height, we retumed to our tent, re- 
joined 'Damntless,' and proceeded on to Cape Disraeli. Our old friend, the wolf, now rejoined, but the eharm was broken; the tabu no longer existed: he had better keep ont of range: I had lost all confidenee in his "trinsty" and lonest intentions; he was henceforth a vietim to seienee, if takcn, and might eventually figure in one of our national museums: I find Parry did not obtain one.

About six A.M. on the 25th we took possession of our old quarters under Cape Disraeli : bears, both old and young, had been searehing; but it is strange that they did not devour our fat pork, baeon rinds, ete., which were still apparent and untonehed. I resolved now to seareh this southern channel, and therefore sent the erew of the 'Damtless' to rebuild, on a larger seale, our upper' mark on this eape: I considered it yet possible that some sharp turning easterly might again throw us into some connection with another channel leading to Jones's Strait. My own preeonceived opinion, in August, 1522, relative to the vapour or apparent smoke seen from the deck, and reported from the crow's-nest " as fog rising from water behind the range of momntains," now reeurred to me. It was clear to ny mind that there was abundant water to produce any quantity of such vapours; and our position here being but twenty-eight miles and threcquarters north of my position on Point Hogarth, and, dedneting eighteen miles for the interval of land, there was yet abundant seope for any ehannel taking an easterly course.

On the 26th, at seven P.M., we started on this exploration, under sail; a fresh snow-storm breeze sent us 
unpleasantly fast orer the rongh floe, cndangering the sledge: it was very similar to that encomterce in the creck in Northumberland Sound, in April, but the ice was less undulatory. In order therefore to avoid this, we hauled close in to the land, ranging the snow line, just within the tidal ridge, or where the land-water would leave level surfaces.

The 'Dauntless' being yet far astern, we delayed for' her coming up, erecting several piles, and examined one on a hill, which had deccived us considerably. Once I became cntirely cut off by a snow-storm; and being alone, and fearing the sledge might move forward and miss me, at the rapid rate it travelled, left me not very comfortable. On the 'Dauntless' rejoining and weather" thickening, we pitched for the night under shelter.

At seven P.M, on the 27 th, the weather having slightly improverl, we moved forward, dirceting $\mathrm{Mr}$. Grove, of the 'Dauntless,' to erect a beacon on the opposite shore. We steered for the base of a very remarkable hill, which jutted considerably into the channel, on the opposite side, where Mr. Grove had been instrueted to rejoin me: having lunched there, we conmenced the ascent, merely intending to place a pile on the first level. A brace of ptarmigan led me higher, one of which the gun killed, when I noticed a structure over my head which seemed to offer materials for a cairn: as I neared it I began to trace the operation of art, and a few moments sufficed to place me beside a cairn, or lollow dome, constructed by man, and evidently of comparatively recent date! This required attention: the stones were carcfully remored, the minutest piece of moss or snow being scarched for 
any relic stowed between, which might afford some light as to its formation, or by whom. We were totally unsuecessful; it therefore only remains for me to describe its construction.

It was a double conc, bcing about cight feet on the axis and about the same at its greatest diameter: the rough computation at the time gave about forty courses of stone, varying from two to four inches, all parallel, selected slabs, and some appenred too heavy for any pair of our men to transport even for a few yards. These stones were not similar to those in the immediate vicinity, but were evidently obtained from a lower sandstone level; low they could have been brought up to this position was perplexing. The surrounding stones

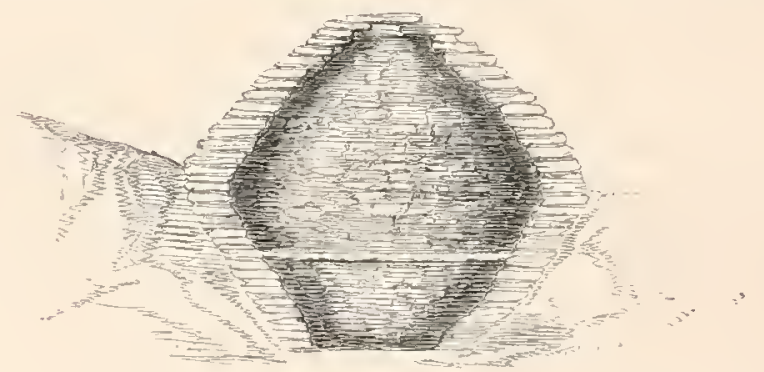

were all of large size, and would possibly afford some, but none of the peculiar gritty sandstone of which the upper and larger tablets were composed. The internal height, excepting in the centre, was not above four feet; and the interior appeared, as each slab was removed, to have been very carefully filled in with small flat stones and moss, and yet no moss was to be found growing near it in any direction! It was marsh mose, and must 
have been brought from below. The orifice at the apex was about threc fect in diameter, and the covcring-stonc had been left open, by which it bccame partially filled with snow. The gencral impression was that it was of recent construction : no tracc of age was visiblc, although crery adjaccnt stone on the mount borc a most rugged, barren, weather-worn, and lichen-covered aspect. I would lave named it Mount Desolation, but Cape Disappointment was substituted.

Every instant I expected to hear some shout of surprisc; but all was mystery,--no document, European or Esquimaux. Its position was in itself curious, standing on a shoulder of the hill, commanding a view up and down the strait, and about fivc hindred feet above the level ; the asceut also vcry fatiguing. I cannot imaginc it to be a cache, for it would bc mere amusement to a bcar to dismantle such a structure. At one time I fancicd it built for temporrery shelter; but it was a work of too nuch time for such an object, and, situated as this was, no such idea could be cntcrtained.

On reaching the base we were rejoined by the "Dauntless,' and again moved forward; Mr. Grove had killed onc ptarmigan. They were again despatched on a spccial mission to the opposite coast, whilst we continued along the western shore. Procceding to the ncarest spit point, we pitched, and fortunately killed two ptarmigan. The coast here is cut up by mountain streams (when do they run?) into all imaginable terraces and ravincs, leading onc to imagine that at some time this strait must be all in commotion; possibly it froze when it last was so, for the iee at present does not lead one to imagine that 
it has thawed for ages!-heavy, wavy, whitish-blue ice, but partially eovered with snow, and presenting more of lake than sea formation. When these rivers are set in motion by the thaws, it is not improbable that they flow over the ice and freeze immediately. The temperature on the land when thaw oceurs at present I find, at three feet above the earth, to range between $20^{\circ}$ and $24^{\circ}$, when at the same moment it would exhibit a temperature as low as $14^{\circ}$ on the floe surface : the thaw therefore must result from the absorption of heat by the earth and stones alone during the day.

The latitude of this position was $76^{\circ} 34^{\prime} \mathrm{N}$., and it received the appellation of Ptamigan Station from the birds killed liere, as well as being our first fresh halfmeal obtained from our guns. The soil eomposing this point being a very fine sand, eovered here and there with patehes or tufts of saxifrage, without a trace of rock, eompelled us to construet our pile of the tufts, eemented with moist snow and sand, which, freezing as we progressed, led us to hope that it might at least hold together until our next station was established.

On the asth of May, the temperature having risen, we were ineommoded by a fall of moist snow, suffieiently heary to detain us to elear out and restow our sledge, so that we did not sueceed in quitting our position until near nine, which delay enabled our consort, the 'Dauntless,' to rejoin, when we proeceded towards the southern depth of the bay, estimated as distant five miles, and not at all indicating any prospeet of an opening.

If one trusted merely to appearanees in this service, he would most assuredly, in many cases, be deceived; 
and it is one of the unpleasant duties comnected with searel of the nature imposed on us, that the truth must be proved, not guessed. Forward we moved, and at michinght, enjoying a brighter sun than we had experienced for many days, halted to luuch at its easteru depth, fully believing that our journeying in this direetion was at an end. During the period allowed for this meal, I ascended the hill immediately above, and there detected that two low, overlapping points, immediately beneath, concealed a narrow channel connecting another great bay, and that furtlier progress was available at least five miles, and in the distance an cxtensive floccovered sea conld be traced to the horizon: that sea, I knew at onee, could be no other than the Wellington Cliannel; and thus were we rewarded for onl persisting against lope, and, I may say, strong opinion, by the discovery which was now presented.

Moving forward with much improved spirits, we soon opened out a new scene, and passing through a very narrow gorge, not execeding an eightlı of a mile in width, found ourselves within a spacious basin, extending to the soutl-east and south-rest. The ice within the points immediately elianged its cliaracter from the common smooth travelling, snow-covered floe, to the bared, undulated ice noticed generally in deep creeks, rendering our footing very inseeure, and sledge-travelling troublesome. About four $A$.M. we reached the sonth-eastern angle of the basin, where a narrow tortuous elannel, still affording sledge movement, appeared to conneet the two scas by tidal lakes, and this very apparent by the ocemrence of fre(quent pyramidal breaks, oeeasioned by the rise and fall of tide over the roeks subjacent. 
During the examination of some of these irregularities on one of the upper levels, by the aid of axes, etc., the water was detceted ruming in a pretty smart current beneath, and, on tasting, proved to be sufficiently fresh for washing purposes, thus affording to our crews a very unexpected treat: at one spot we found also pure, fresh, lively aerated water, the first we had noticed since the previous August. To explain the importance of snch a discovery, it will be merely necessary to observe, that all our water obtained hitherto involved an expense of fuel, by thawing snow, and therefore it was a most precious commodity. It had been our general practice, as far as saving of fuel would permit, to warm sufficient water daily to afford some kind of ablution, more particularly to the cook, and this was found very materially to refresh and invigorate the crew, as well as to conduce to their general health. Washing and drinking therefore beeame the fashion at this "watering-place," and in these excesses they were suffered to indulge during our detention, much to their improvement in general health and comfort, as well as in personal appearance.

Leaving our hands thus cngaged, and pitehing the tents, I commenced a stroll up the mountain immediatcly overlooking.

It is curious at times to reflect how this habit of strolling, and without any sensation of fatigue after a land day's travel, finds one uneonsciously, and I might say injudiciously, perched ligh above his friends, umprepared and unarmed for offence or defenee. I had in this manner reached a commanding elevation of fonrteen hundred feet, affording a magnificent view of most of my wellknown olyects in Wellington Channel;-Cape Majendic, 
Dundas and Hamilton Islands, westerly; and to the castward Cape IIogarth and nature's own cairn were clearly defined. But 1 had brief time to dwell on these objects: my attention was arrested by tro structurcs, not many yards from where I stood, and, from their outlines, exciting greater interest than the cairn notiecd on Mount Diseovery, 'These were apparently graves, and, to my senses, raised by Europenn hands; moreover, in no single feature did they rescmble anything hitherto noticed among Esquimaux. I approaehed, cxamined them, and still felt more convinecd that in the prescnt case my conjeetures were well founded. My first impression was to remove the slabs, and proeeed to the examination, but they were very heary; and it occurred to me that the disturbance, as well as examination, should be undertaken by other parties present to witness the result. I therefore desisted, revolving in my mind, during my return to the tent, the diseovery of the before-mentioned cairn and these two objects, and fully prepared to expect some result throwing satisfactory light on the objeet of our Expedition.

The dircetion of these structures was east and west (tme): the length too great for the body of any Esqui-

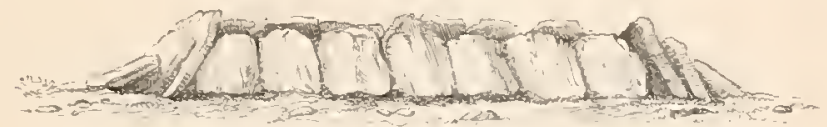

manx, being about seven or eight fect, and three feet in widtll: each end was terminated by threc slabs, overlying each other in gradation, and to my ideas intended 
to represent head and foot stones. If one such structure had been a freak of Nature, she seldom repeats such freaks within thirty yards.

May 30.-About six P.M. the sledge erews separated; that of the 'Dauntless' to examine the outer remarkable headlands, and erect conspienons crirns, and our own party to seareh these struetures and the general features of the coast easterly.

After a very elose examination, removing every loose stone to the foundation in the solid roek, not a vestige of anything but black dead moss was discovered, and portions of this so blackened and pressed that it was at first mistaken for liuman hair; however, after due examination under the microseope, and subjection to fire, its vegetable origin was elearly proved. At the very base, interspersed in the moss, numerous minute black eells, subsequently proved to be the chrysalis eoverings of minutc flies, * were deteeted,--which leads to the inference that these may liave bcen caches for decr, ete.

That these formations wcre construeted by human hands, I have not the slightest doubt,-moreover, in all probability, by the same tribe which raised the eairn; but for what purpose remains still a matter of perplexity. If for a cacke, what nccessity for moss? for no moss or vegetable production exists on this mount, and all this is withered: beneath, near our tent, moss was very abundant. But if they abstracted their food, why cover the spots again so mystcriously?

* These larve and chrysalides in 185 t were discovered in peat near our winter station: they probably belong to the remains of lemmings, which resort to hollows under stones for shelter. 
From these now demolished structures we construeted a very substantial caim, seven fect in diameter by nine in height, stripping the pseudo-graves to their bases, which we found to be exeavated out of the solid roek. But from whenee these heary, durable slabs were obtained still remains a mystery, as the rock composing the surface of this mount was chiefly of a loose, rubbly; fossiliferous limestone, hardly eohering suffieiently for removal in tolerably sized plates for eonstrueting our pile, and between the lamina abounding in Terebratula, Entrochi, etc. None of the supposed grave-slabs were of this very loose charaeter, and although we visited two other stations on this same lange, the stone was found to be still more rotten and rubbly,-exhibiting however columnar bits of two feet in lengtl by about fonr to six inches square. Nothing at the base favoured any formation of solid stone, and the only position not examined was on the north steep incline, where it appeared to have a slaty structure; but that would require great labour to tramsport up at least a hundred feet of hill, and tools also to work withal. By trigonometric measurement the height of this hill, to which the name of Grave Mount was given, was found to be fourteen lundred fect, and our position at its base to be in latitude $76^{\circ} 23^{\prime}$ nortll, differing but ten miles in latitude from my position on Cape Hogartl. Noving to the eastern summit of this range, which completely conmmanded all the features of Prince Alfied Bay, stations were taken up, which completely confiner its limits, reducing it somewhat from its former dimensions. At this moment all onr cainus were purposely eonstrueted to aid in any operations hereafter 
from TVellington Channel; and, curionsly enough, our detention in the following August rendered them important aids in fixing our positions, whilst drifted to and fro by the moving floe.

The strait comnecting the two seas received the namc of Arthmr's Strait, in compliment to the Prince, as well as to the Dukc, his noble namesake. The range behind was named the Douro Range.

The 'Dauntless' party returned from their labours nearly about the same moment that we reached the tents, having done good service about nine miles to the west, where two more conspicuous cairns attested our right to tcritory on what must now be termed Prince Albert's Island.

The following day was passed much in a similar manner, with the difference of our party visiting the most conspienous onter lieadland, immediately on the verge of Wellington Chamel, and about ninc miles from our encampment. This position enabled mc, by direct reference to our eairn on Cape Hogarth, to verify all longitudes in eommection with Beechey lsland, and to confine Baillie, Hamilton, and Dundas Islands within limits easterly. The day proved bitter cold for handling metal instruments, and the vapour which floated in the air, although imperceptible to us, constantly impeded my operations by forming a thick incrustation of ice whenever the object-glass was exposed to the breeze; the slect also covered the instrument with a fine sheet of filmy ice, which destroyed its motion. One deer was secn, and my coxswain (one of Sir Joln Richardson's land party) sent to kill it, but was unable to get within range: it 
was very small, not exeeeding the size of a small ealf or goat, and was furnished with a pair of small, flat lorns, which some of our men, not inappropriately, eompared to the sails of a windmill.

This night travelling has, I find, a very peeuliar effeet on my coustitution. I am not muelı addieted to sleep at any time, and obtain but little ealeulated to support my eonstitution; but on the marelı, generally abont two A.M., or after lmeheon, I am frequently seized with an meonquerable and very painful stupor, eompelling me to lie down or sit on the sledge during the ten-minute halts. Today I was eompelled to do so in this bitter eold; fortunately however finding an easy ehair formed by Nature ont of some limestone roeks, whieh proteeted me from the breeze. The doze ranges between ten and fiftcen minutes, is heavy and eoneentrated, and seems to satisfy nature: at least I find myself relieved,-at the expense however of none during the allotted period for rest. I seareely toneh spirits for days,-never at these times, -one day's allowanee (one gill) being suffieient for five or six days. I reeolleet one oeeasion, when a long exposure between Liverpool and the Ribble had exhausted me, that some kind friends notieing my head to fall at evening serviee, most eharitably attributed it to incbriation. The truth was, that I had been all night and two days withont food, and had drunk too mueh sea air.

The outer headland visited by us stands about one mile within the Wellington Channel waters, the interval being eovered by a low, marshy belt projeeting seaward, and thus forming an opposite bay to that of Prinee Alfred. 'I'his fine height I named Mount I'ym, after ny estecmed 
friend Admiral Sir Samuel Pym, his grandson also being my boat companion. From this height, in eonjunetion with Grave Mount, I plainly traced the eomncetion of the two seas by two large lakes, with one of fiesh water feeding them.*

Here I first notieed the effect of a true fog. Our temperature was $17^{\circ}$, with a bitter north brceze, but the air was clear, and objeets well defined. Notwithstanding, the vapour eondensed on every object; and the eoldest, our heavy stone eairn, was, before we left it, it polished eone on the weather side, with the resemblanee of ieieles, or thaw, pendent from the under edges! Subsequently, at other stations I remarked the same. Herc the ground was snow-elad, the sun had no influenee at midnight, and the tempcrature was $15^{\circ}$ below freczing; yet the atmosphere, northerly, was clearly "misty:" does this eome from the Polar Sca?

We were naturally anxious to get baek to our tent, from whieh our eomputed distanee was 9.2 miles dircet. We reached it in five hours and a half, slept, and about nine P.M. on the 31 st commeneed our return up this strait, pieking up a new station at Piteh Mount, which derived its name from a very strong naphtha and asplualt effluvium, added to its swinestone formation. Mr. Grove had aseended it by another route; and informing we that he had passed a small mark, which he would not allow any of his people to listurb, I visited it in my way down. Excitement in every degree secms to pervade

* This has sinee been named Grimell Land, but not by me. I deny the possibility of its being seen by any vessel fiom any point of the parallel of $75^{\circ} 30^{\prime}$ north: Hamilton Island may. 
this channel. On reaching the mark I found a still more perplexing puzzle than any we had yet met with. Solid and heavy struetures we well know are eapable of resisting the pressure of snow, wind, ete; but here was a pile, consisting of five or six stones, constructed with snch mathenatical ability by the hand of man, that it was at present firm and complete, but tottering if any one stone was abstracted!

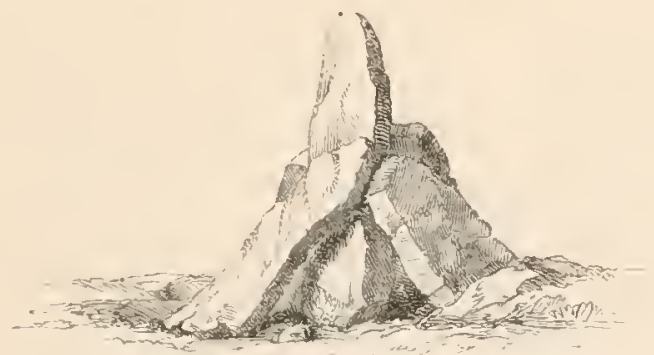

To argue against the visit of man up this elannnel is absurd: man built this eain ; all these objeets lie in his direet path, and he seleeted heights. As to the ability of the Western Esquimaux, I have many convineing specimens of their workmanship, evineing a high degree of intelligenec, and a wonderful habit of adaptation of the means to their objeet. If these struetures had been of this season, I should have imagined that Commander Pullen or Mr. M'Cormick's people had forestalled me in this chamnel: but the operations are, on mature reflection, too laborious for Europeans. They are the result of long delay and constant appliention, to serve some important purpose, - at least deemed to be so by the eollst ruetors. 
Shouldering my gun, I sallied fortlı aeross the bay, prepared eithor for bear or ptarmigan, and visited Dauntless Pilc, where, after a cool walk for some lours, investigating every rock of which it is composed,- and a fine green porphyry was amongst them,-my crew rejoined, and we moved on to sleep at Ptarmigan Station. I was not in good spirits, for a most troublesome swelling of my right eheek (carbuncle) worricd me desperatcly. One never likes to cut oucself up, particularly in such eold weather; and had I been so disposed, could not see to do it. For my own part I attributed it to eating pemmican; otlers, to not eating cnough : doctors disagree. At this station we had an opportunity to sleep without disturbance from the sun at noon, as it commenced blowing unpleasantly from the north-west, attended with heavy snow.

June 1.- At seven P.M. the wind fell, and witl a temperature of $20^{\circ}$ we reeommenced our journey. Shortly after midnight a bear was secn coming down full trot right before the wind, the weather proving hazy withal: we all lay close, both sledges in line and duly prepared, my coxswain having one donble-barrd, mysclf the other, and Mr. Grove behind with his rifle. Bears are very humorous, and even funny, in thcir way. Suddenly he seemed to think he had left something behind, or he had mistaken his objects; possibly he deemed that we were too large for seals, and making an awkward bow, as I thought, within forty yards, was on the retreat: five barrels were discharged, dogs set on, and the hunt commenced. I rcmained by the sledges, lcaving the younger ones to tire themselves, and quietly measured the dis- 
tanee to where he was, when I fired: this I found, to my surprise, to be one hundred and forty-six yards. Still, if the grmus lad been good, our game would lave been seemred, the $\operatorname{dogs}$ fed, and we should have saved very valuable fuel. The party returned unsueeessful. Puneh alone would not give up; ${ }^{*}$ lis tongue was heard long after" and when it eeased, I felt very mueh afraid that le would tire himself and beeome an easy vietim: but bears will run, and are not very anxious to faee a dog.

We pushed on for Tongue Point, and there pitehed. More bears! I was busy on the Point with the instrument, watehing for an object, when I notieed a lady and her eub, ammsing themselves, as I imagined, at a game of romps, but the old lady was evidently the more exeited. Possibly no sueh opportunity has before been afforded to any naturalist of witnessing quietly the humours or habits of these animals. At first the motions of the mother appeared to me as ridieulously absurd, or as if she was teaehing her eub to perform a summerset, or something nearly approaehing it: but the eub evineed no interest, no partieipation in the sport-indeed moved off and lay down, apparently to sleep. The anties too of the mother were too distant from the eub to prove instruetive. I will endeavour to eonvey my impression of the exhibition, as viewed through the teleseope, at a distance of a quarter of a mile, as well as the objeet on whieh she appeared intent. It must first be borne in mind that a bear of sueh dimensions as that before me would weigh about six and a half or seven hundred-

* Punch is one of the Cape York dogs, now at the Zoological Gardens: the bravest of his species. 
weight. 'The object apparently in view was to break a hole in the iee. In order to effect this, the claws were first put into requisition, and, as nimbly and gracefully as a dog, did the lumge creature tear up and scatter snow and ice to the winds : laving removed, as she imagined, suffieient, she then appeared to estimate her distanee, ealeulate on her leap, and in the effort eame down perpendicular on her fore-paws over the spot whieh she had scratehed. Something, slie imagined, had been effected. She eontinued to repeat this seratehing and amusing mode of pounding until at length she appeared satisfied, when she assumed an attitude of "dead point," with forepaw raised, and remained for" some time immovable. The question oeenrred to me, "Is this a mode, by concussion and making a hole, of sedneing a seal within gripe?" for I have repeatedly noticed that when we eut for tide-pole, fire-hole, ete, that these inquisitive animals will show themselves. This, however, I leave for others to verify. We now proceed to other business. Puneh had rejoined: Mr. Loney and one or two of the party, attended by the dogs, endearoured to get within shot: but Punch, poor fellow, was done up, and eould not be brought to the scrateh. The cub evidently had sealed orders to open somewhere south-west: she bore up. Mamma steered away south-east, and parted eompany, apparently after the former bear, possibly her husband, and our party returned to pemmiean and sleep. The experienee we have had of bears' habits fully warrants the impression that they are afraid of man, $\log$, or wolf, singly, _and would inevitably run from them if escape was available; but cases may occur where, finding themselves suddenly and 
unexpeetedly eonfronted, they are driven to desperation, and endenvour to show fight. All animals at bay are dangerous. The Polar bear is emming and inquisitive, and having diseovered your power, very wisely declines the eombat.

About noon the heat in the tent beeame very oppressive, the internal thermonieter exlibiting $80^{\circ}$, when that outside stood at $30^{\circ}$; the heat, nevertheless, exposed to sun, was biting. At six A.r. the faee of this sloping point was eneased by an entire sheet of iee, seareely affording standing ground, and eompelling me to resort to the aid of a boarding pike for safety : at six p.s. thaw had entirely denuded the point, rendering it unpleasantly soft and yielding. This uneovered the skeleton of another whale imberded in the soil, about eighty feet above the mean level.

About six P.s., with a favourable wind aiding, we again pushed forward, reaching about midnight the skirting belt of Cape Disrneli, and, as time was precious, taking two of the party, I took the mount "by the liorns," obtained the requisite observations, rejoining the division about the time they renehed our old eneampment. We experieneed a bitter eold wind on the summit, and a repetition of the freezing fog alluded to at Cape Pym. The result however repail the exertion, and spared a speeial aseent during the proper time for rest. I had beeome very anxious during the late high temperatures about the "north water," fearing that if it made, we might be impeded in our eontemplated expedition to the new islands seen in the nortliern horizon.

At this station a flight of brent-geese, an owl, sereral 
plover, and a few snow-buntings, were noticed; and the snow having disappeared from the lower slopes, revealed a pretty fair collection of vegetable life, affording tolerable feed for deer or musk-oxen, none of which however delighted our expectant eyes. 


\section{CHAPTER XII.}

Iamilton Depôt.--Mount Parker.-Patches of Water.-Musk-oxen.Dr. Lyall and Mr. Allard rejoin.-Preparations for search Northwards.-Lost J)og.-Freaks of Refraction.- Western Island.-Effeet of Sun's Heat.-Buchingham Island.-Dcal-holes.--Bcar-hunt.Recovery of Sledge.-Watercourses.-Rounded Pebbles.-Surface Disturbances.-Cape Ogle,_Water-fowl,-Lemmings.-Star Bluff. -Return to the Ship.

June 3.-T'ris bcing our third visit to this station, it afforded a good rating position for the ehronometers, and scrved to secure all our operations casterly: it had also the advantage of being further tested by a complete chain of triangulation, carried through Arthur's Strait and into connection with our first position at Cape Hogarth. Quitting this about 6.30 P.M., we pushed forward towards the Hamilton Depôt, in order to pick up the boat and rejoin our reinforcement at Princess Royal Island. About midnight we reached the boat, lunched, took out our provision and boat, rebuilt the pile, and moved forward, clogged a little by the additional labour required for the 'Hamilton,' but suceceded notwithstanding in gaining our old quarters, under Cape Parker, by scven A.M. This distance, from the fact of knowing the best road, and being altogether in better travelling disci- 
plinc, was now accomplished in twclve hours; the outward journey occupied thirty-six hours, or three travelling days! A bear came boldly down upon us, and probably would have affordcd us fucl and dog's-meat; but, fortunately for him, my coxswain, when last in chase of the old lady and her cub, had loaded with snow before the powder, which was now found useless, and further entailed great difficulty and delay in discharging, rcloading, etc., indepcndent of crippling the ramrod. Bruin madc off very leisurely, yet still continued to evince considcrable curiosity. Three of our party volunteered to accompany him, but he was very suspicious, vouchsafing them very little attcntion, and mcrely increasing his pace from time to time to preserve a dignified distance, which laving attained, he leisurely turned round to scan lis impertinent intruders. As our affail's did not admit of delay, we were soon en route: on crossing the flats, now barely skimmed witl dirty ice, we noticed fragments of coal, chert, shells, ctc., which had been washed up probably last season.

About seven P.M. on the 4.tl, the 'Dauntless' and the 'Hamilton' were despatched in advance, our party asccnding the mount, in order to obtain, if possible, the bearing, as well as the best route through the off-lying pack to our new islands. From the summit they were barely seen, but I had a very clcar view of the eastern boundary of North Cornwall, confirming my idea of its being an island; no land intervened between it and the capped hills of our northern gronp. Even to have secn them was satisfactory, for those who did not view them llirough the instrument deemed then imaginary. In 
the north-west direetion the sea presented several large pools and lanes leading towards Table Island and westcrly; but this was more espeeially evident in those localities where I knew the tide to prevail with peeuliar foree. Several snow-buntings and two plovers were notieed. One or two lumps of inferior coal, jutting ont of the general débris of mud and limestone; one roeky elmmp of elay iroustone, much broken up by frost into large rhomboidal masses, and some few picees of selenite were pieked up. One would almost imagine that this partieular mineral liad the value of gold; it was seereted by the finders, and obtained a variety of names, - that most prevalent was mica or tale. Shortly after midnight we moved forward to rejoin the 'Dauntless, whieh, although hampered by the boat, liad gained greatly in advance. The sum was oppressive, and as our men were mueh fagged, we pitched, at the usual hour, about halfway between Cape Parker and Princess Royal Island, and one mile from the 'Dauntless.' Shortly before noon, whilst engaged in taking my customary round of angles, 1 notieed three dark objeets in the field of the telescope, and that they were in. motion on the side of a hill: it was very soon evident that they were musk-oxen, the first elear proof whieh we had of their existing on this side of the Queen's Chamnel. I also notieed on the imner end of Prineess Royal Island a eairn and staff, by which I felt assured that our relief party had arrived, and, euriously enough, to the very day I appointed, although I did not intend to meet them when I parted with Mr. Allard.

On the 5th, about eight p.u., we moved forward for the island; the weather hazy and umpromising. Shortly 
before eleven we notieed a flag on the south beaeon, and a party was diseovered advaneing to meet us from that direction. A little before midnight I had the pleasure of shaking liands with Dr. Lyall and Mr. Allard. 'They had reaehed the rendezvous, aceording to arrangement, the night before, bringing the latest intelligenee from Commander Richards, as well as the missing despatehes, whieh were found on the seeond attempt (aceompanied by Dr. Lyall) just where they should have been on the first visit, had proper vigilanee been observed.

After luneheols we moved forward to the nortl end of the island, where the other sledges were direeted to as. semble, bringing up the depot. Time being now a valuable eommodity, I aseended the peak of the island, and fortunately obtained the most important stations: I also saw our new islands, and thus I imagined all doubt was sileneed. A muel inercased eairn was ereeted, and we returned to our tents.

The so-termed "despatehes" did not eontain one line from the Admiralty; they were simply serviee letters or offieial returns from Commander Pullen. By this eonveyanee I reeeived details of Commander Inglefield's proeeedings and diseoveries in the 'Isabel,' at Whale, Smith, and Jones's Sounds, and I now regretted that he had not been able to obtain one satisfaetory line to my eastern headland from that side; but the eheering intelligenee that the Squadron generally were all supposed to be pursuing satisfactorily, and without obstruetion, their several allotted duties, was matter of eongratulation : so far all well. Next, my despatehes from Commander Rieliards were very satisfaetory; the rendezvous, differ- 
ing only a few miles in latitude, had been visited, but no accounts of Captain Kellett or his division. Mr. Herbert, the last detached officer from Commander Richards, lad returned, reporting, "All well, doing well, and in ligh spirits ; Lieutenant May yet expected."

The wind had now set in strong from the northward and westward, attended by thick weather and snow. About two A.m. the relief party rejoined, bringing up the depot from the southern shore.

Tune 7.-I had now made my arrangements to proceed with the 'Hamilton,' accompanied by the 'Lady Franklin,' Dr. Lyall, with fifteen days' provision, to the islands, and to send the sledge and tent, with remaining provisions (fifteen days'), to the mainland, inside of the island. 'The 'Enterprise' and 'Dauntless,' taking up all caches, were to remove them, depositing at Star Bluff five days', at Depôt Bay five days', and Village Point five days', and bearing additional orders to the Commanding Otficer at the ship to send Mr. Pym with the light whaleboat, already fitted under my own inspeetion as an iceboat, to be in readiness to aid shonld the water make from Village Point.

At first I had intended to go alone, but I soon perceived that the crew could not dragr thirty days' provision in the boat alone, added to instruments and other heavy requisites. It was fortunate that I changed my purpose in time; a few hours later would have entailed greater labour than we alone could have mastered. Our number's now amounted to eighteen men and officers, with seventeen days' provision. 'Two men were sent back with instructions "that 'Dauntless' crew were to await 
my return, and guard the tent." This was mistaken, failed; and we lost thereby, in all probability, the muskoxen and other game. The York bitch, supposed to have becn murdered by some bear or wolf, after twenty. two days' alsence, rejoining in apparent good condition, was sent back with these men.**

June 8. -The rough pack ice presented scrious and tiresome diffieulties, and the occensional appearance of water, into which our men frequently put their boots knecdeep (without injury or wet), damped, I fear, for a time, the ardonr of some of our new hands; but the old party knew as well as I did that we should soon find the old floe, over which we had travelled safely, at no great distance. Nany random shots were fired, none told; the "flying islands," "water making," and other such lints, all passed by harmless; my determination was not easily set aside; on we went in silenee, but tongues were loosencd as we reached the solid smooth floe. Countenanees varicd as the weather improved: what wonders the sun offeets, even in these elimes!

On the 9th, the outlines of the northern land began to make elearly, indeed to loom large; our prineipal difficulties had been surmounted or ceased; the ice was firm, the floe smooth, and no traee of open water could be discovered. Bear-tracks had beeome rare, and Punch, poor animal, driven almost to desperation by hunger, having had nothing lately but the scraps of the party to subsist upon, robbed the chest of four pounds of pem-

* This is a most remarkable event : it was half-starved when it left us, and how it sustained itself for this long perior is quite unaccountable. 
mican. As far as my own feclings were enncerned, right glad was I to hear of it, as it enabled me, witlout murmur', to make it good; my allowance was stopped until the deficiency was covered. It was undonbtedly my province to order the proper allowance for the dogs; but I was well aware that, under the possible privation which might attend our adventure, the allotment of pemmican would be viewed with great jealousy by some of our party ; and yet, if these poor anmals did not work, to lighten their labour abundant whip was bestowed by these same pseudo-feeting bipeds! Snow, but not auspicious, continued to fall, and the barber within the tent troublesome: sevcral of the men also were affected by reakness of the eyes or partial snow-blindness, doubtless the result of the late prevailing easterly wind.

About two A.M. on the 10th of June, the weather elearing, discovered to us the land, very distinet, but at times so distorted by the play of refraction as hardly to prescre the same features beyond a few minutes; or, once having caught the true image, wandering into every

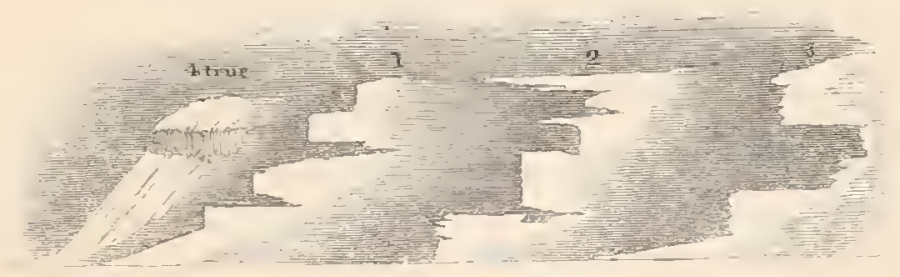

imaginable phantasm fancy might suggest. Such were four diagrans, as here given, No. 4 being the final or true apjearance of the object. 
About nine A.M., the vapours having been greatly dispelled, I contrived, by close watehing until near two P.x., reading the same object perhaps five or six times, to realize a set of angles. No one but a surveyor can possibly comprehcnd such labour; possibly many would not, but take their legal allowanee of sleep, mueh more refreshing to the animal; to myself it was no loss, indeed I could cnjoy with more satisfaction the small quantity requisite to sustain me, whieh, as a maximum, may be concentrated into two hours, and very fortmnate do I deem myself when suelı a luxury can be obtained. Our noon latitude was $77^{\circ} 2^{\prime} \mathrm{N}$.; forty-cight hours will, I trust, cnable us to plant the Union on the terra incognita of this new region.

Shortly after two P.M. I underwent the wriggling aetion of contrneting myself horizontally into my chrysalis case; the attempt in a free tent may not be so diffieult, but confined to a space of two fect, and fearing to disturb others, it exhausts one's energies, and is followed by a sensation of faintness. My own bag liad becn altered, to suit my restless habits; the aperture being "a shark's mouth," cighteon inches from the head, the upper portion eonstituting a complete lood, protecting the erown of the head from side-wind or drippings: by merely elosing the mouth of the bag it became a complete envelope.

Alout five P.s. the word "cliocolate" turned up many disappointed faces, so fond are mankind of that intoxieating passion-sleep; yet the law, "Out and pack before you breakfast," requires the rolling up of beds and a clean sweep for a comfortable meal. I was myself rather 
inclined to sleep, but law-makers must set a good cxample.

T'wo islands, equidistant,-one northerly, the other westerly,--presented for selection; anxious however to obtain further intelligence, if possible, of the boundary of North Cornwall, I decided to push for the western, suspecting, from a very deceitful haze which prevailed, that open water, or moist floe, which was worse, intervened between us and that to the northward.

On the evening of the 11 th we pushed on westerly, in high spirits, until reaching a heavy ridge of hummocks, which at first sight seemed to offer serious obstruction; but its outline liaving been overeome, revealed merely the result of a severe nip, beyond which the smooth floe again prevailed.

About seven A.M. we pitched, with the sun bright, rery oppressive, and biting severely, the temperature in the shade being from $22^{\circ}$ to $2 S^{\circ}$; the natmral lesult was that all our objects were shrouded in misty vapour, tantalizing us by the vision of the bases only of points, bays, ete. Our latitude was $77^{\circ} \mathrm{S}^{\prime} \mathrm{N}$. At 6.30 we advanced towards our island, at that time the only object visible, hoping to reach it before midnight; in this however we were disappointed by the obstruction offered by the belt of island pack, which delayed us until two A.x., whell we pitched on terra firma and hoisted the Union. Possession being taken, we lunched, and commeneed the ascent of the nearest elevation, and there established the instruments.

Before proceeding further it may be as well to describe this "belt of island paek," for clearly it can only result 
from the great floc having a tidal motion baekward and forward, casterly and westerly, at a time when the temperature admits of the broken floe remaining afloat as loose pack. At the period of our visit all was firmly frozen, and no eontinuation beyond the outer circle seemed to afford proof of any but the action which I have described. The ice here did not seem to have been foreed with so much violenee on the land as in the vicinity of Exmouth Island.

At the tine we eommeneed our ascent of the hill, which was about two hundred feet above the level, the temperature was low, $28^{\circ}$, with a eool refreshing air; the soil was well frozen and firm, and the summit land covered with a slight erust of snow. 'The island is belted, from the first base of this clevated range, by a low marshy slope of frozen mud thickly eovered with tufts of grass. This mud is the result of the débris during the summer thaw, which appears to lose itself in the sea, distant from the elevated land about a quarter of a mile. The solid elevated land is deeply ehannelled into ravines, presenting, on some of the sides, vertical dark-eoloured masses of rock, probably, from the general distribution of fragments which I examined, of clay ironstone. The interior presents smootli, rounded hills, deeply elothed with snow, and rising to between seven and eight hundred feet, but very difficult of aeeess by reason of the show in the intervening ravines.

On the lower skinting we noticed the tracks, as well as reeent deposits, of decr, hares, and ptarmigan; and as we ascended the elevation, antlers and other marks of recent animal prescuee increased. One antler still exhibited its 
skin eovering, partly adhering: and from its perfume on exposire to the sum at this early date, must have belonged to a recent visitor.

Dr. Lyall found amusement in shooting at plover, brent-geese, and ducks, on the low belt, at least until supper-time. But having taken my station on the hill, I was in no humonr to deseend until my work was complete, and that would detain me until two p.ns. at least. As the men must liave rest, a wateh was established until that hour; the little food that I required, being sent up when oceasion offered. However, two of my guards wished for exploration, and it being their wateh I released them. They ascended the highest snow-clad mount, and as they explained themselves on their return, mueh fatigued, "Deepish; not fit for you, Sir!" I was satisfied. On the highest mound they construeted a mark with antlers, and returned with the one alluded to, evidently dropped this year. From their account of the land secu westerly, I had already viewed the extremes of that gromp from positions on the floe. At the time we commenced operations liere the soil was well frozen : and into that state, water exposed a few minutes would also be reduced. The ground betrayed no syniptom of weakness: it was partially snow-clad. But as the power of the sun increased towards noon, the snow about me disappeared, the instrunent legs sank decper into the soil, the levels shifted and frequently required adjustment; yet still the temporature, as exhibited by a thermometer protected from sun, and lianging to the tripod of the instrmment, sometimes behind our earth-pile, simply indicated $25^{\circ}$, or $7^{\circ}$ below freezing. As noon passed, 
the soil in all the hollows or small watercomrses bccame semi-flnid, and very nncomfortable to walk on, or sink into. At the edge of the southern bank, the mud could be seen actually flowing; reminding one more of an asphalt bank in a tropical region than our position in $77^{\circ}$ $10^{\prime} \mathrm{N}$., and, when a mist too decply enshronded the sum, attended with anything but pleasurable f'eelings. Thic entire aspect of onr immediate position, and bencath, presented the features of a newly-drained lake, the lower land conreying its fhid mud to the sea. The soil, a dark brown ferruginons clay, resnlting from the disintegration of elay ironstonc, black and glazed by cxposure to the sun, and cracking into eompartments, impressed on my mind the probability that a continued serics of hot days would naterially elange the ontlines of my present position, converting it possibly into a similar slope to that now exhibitcd beneath. Even where I stood, the temperature, basking in the sun's rays, was biting at $25^{\circ}$,with the sum elonded, chilling: but I am informed by those who were in the tent, that the heat was ahmost insupportable! As to my surveying observations, which eonfined me to the spot, they have bcen before alluded to ; but at this position I experienced infinite amoyance from the incessant derangenent of the levels, rendering repeated adjustment imperative.

How these islands were originally produced, I leave theorists to determine: how they are changed, and ehanging, requires no great reasoning porrers. About two P.M. I was not at all sorry to commence our descent, but we experienced very dirty work before this was effected. The entire slope, in consequence of the thaw, 
had become a fluid moving chute of débris for at least one foot in depth, and the attempt which we made on the stcep part was highly dangerous, particularly to the men who carried the instruments. Retreat was impossible, and our only chance was to put forward our whole efforts and reach the flat. Heartily thankful were we to regaim the tent, for smothering in mud was an inglorious mode of exit. I have continued the use of the term "tent,"-but the 'Ilamilton' served this purpose; and as she was always dry and warm, at this season particularly, she was invaluable.

'The island received the name of Buckinghan, and the mount Windsor,-after the royal palaces: the entire group was called the Victoria Arehipelago.

One circumstance connected with these islands still continued to puzzle me. I could not but think it strange that as the outlines of these islands were clealy and distinctly defined from several of our stations, on mountains of fifteen hundred feet elevation, that these same cminences were now entirely hidden, notwithstanding they were searched for in the computed dircetion witl good and powerful instruments. The summits only of these islands were seen from Princess Royal Island, from whenee they appeared but as dots on the horizon. Further reflection on these matter's elearly convinced me that, from height to height, objeets of one thonsand fect elevation could not be sutivfactorily seen at a greater distance than forty miles. From Mount Vietoria every feature of this group was distinetly visible, and strongly impressed on my mind,--never to be erased. Each point, - bluff, ete., was duly registered; and when, at a later pe- 
riod, the "Cloud Islands" were oceasionally hinted at, I must eonfess I was surprised; but as no one at that period ventured or wished to look through the telescope, the vision was not to them revealed.

The fatigue on this occasion prepared me for sleep, and for obvious rensons I was not disturbed until I was rendy for chocolate, a term very significant in military life: indeed I believe that by general consent it was deemed convenient to make the most of this delay. About eight P.M. we struck our tent, and extricated ourselves from the surrounding pack, bidding an eternal adieu to this interesting group. Our last floe station, previous to landing on this island, had been marked by a large snow pyramid, surmounted by a blue flag: towards this our course was directed, and on reaching it wo pitehed for the day. At noon, althongh the thermometer in the shade slowed $34^{\circ}$, and it was dead calm, the heat was oppressive to our feelings, but not the slightest action could be deteeted on the floe; the only change noticed was that the eovering snow, instead of cxhibiting a flocculent light character, was found to consist of minute, spherical, transparent globules, like fine hail. At this time probably the floe was undergoing the internal change which renders it "rotten;" and the vapour resulting assists, with the sun's rays, in converting the snow into the globules deseribed. One cirenmstance was frequently remarked,-that the soft, heavy-travelling snow of the day generally changed after six P.M., when the temperature fell, to a compact solid bed ; sustaining in a more satisfactory degree the men and sledges, affording a firmer footing, and very considerably facilitating travel. 
Such is my own view of the matter. 'This reduetion of the snow was, after I deteeted the varieties, taken advantage of to facilitate cooking, as the heavy globular variety was found to produee water in less time and save fuel.

Although the tracks of bears did not frequently oceur on this off-shore exeursion, still they were notieed in the immediate vieinity of Buckingliam Island. The absenee of seal-holes, and the general denseness of the iee, may aecount for their seareity: and this leads to the question, How do these latter animals bore or keep open the holes in the ice? I am aware that Nature, even during periods of very low temperature, will keep open certain rents or eseapes; and although frequently skinned over, they are soon removed by the first glanees of returning sun, or by warm eurrents of water beneath. In sealholes however there is generally a conieal, funnel-shaped opening beneath, evineing some power possessed by this animal in thaming the iee. In February they eome up to bask and pup, even when a few minutes might ent off retreat: and although it is generally maintained that bears are eonstantly found where seals abound, sueh has not been borne out by our experienee,-rather the leverse.

In order to seeure our retreat, I determined to reeover our traek over the old floc of May, and follow it up to Cape Disraeli or Mount Parker: this would earry us elear of all diffieulties.

On the 14tl, having reeognized our old landmarks, we soon recovered our former traek along-shore, and about six A.x. pitehed within six hours of our destination. As nothing inportant ealled for my presence, and the sun 
did not lend his cheering eountenanee,--suffering also from troublesome plagues (earbuneles) on my head, whieh weakened me eonsiderably, I was too glad to snateh any repose; and this time Nature helped me-I really slept. When I did turn out, it was not attended by the bustle and lumry of tent arrangements: the boat was my eradle, my special eabin; and there was no neeessity for disturbanee. I kept my own room in order. As we neared the land, we were anxiously looking out for some signal from the 'Dauntless;' but no sign of tent or signal could be traeed; I therefore imagined Mrr. Grove to be revelling in the slaughter of musk-oxen, deer, or ptarmigan, and in any direetion but where we were looking for him. At six P.M. we pitehed on the onter edge of the imner paek line. About eight P. M, we were again in motion, and before midnight well in upon the land-ice, or that barely shenthing the frozen mud-banks beneath, but now rapidly deenying, by the diseolorization enabling the sun's rays to net vigorously. The traeks of bear were again beeoming common, At midnight we halted for luneheon : still no sign; possibly he had again turned night into night, and was asleep. Onward we pushed, with the Union flying-Grove's reeall (he was at the ship!), and at length pitehed, at two A,M., on our old position at Prineess Royal Island. The features of the land were mueh elanged by the denudation of snow. Dr. Lyall, who made a direet eut, not deviating as we did, saw and fired at a large bear,-probably, from the size of the foot, a male. He must have passed very nem to our sledge, but was not notieed, nor did we eren hear the rejort of the gun. On Dr. Lyall rejoining us, 
we discovered his fricnd gradually working a traverse towards us, but evidently very shy : at length we determined to try and circumvent him by ambush, taking advantage, Indian fashion, of every liummock intervening, to steal upon him. Presently I became tired, and as lie had eaught a glimpsc of me, and exhibited a disposition to bolt, I tried my distance with a ball : he whistled in his peculiar way, as much as to say, "T'his is not pleasant," - a sort of twinge of the gout, ctc. Punch was now loosed, and elosed in the most scientific mamner, keeping him at bay in admirable style. Bruin was not quite in command of his limbs, - wounded probably by the doctor and touched up by me; he began to think of intrenching himself, and, finding a convenient hnmmock, albeit at an angle above $45^{\circ}$, backed up: thus enabling him to keep Punch completely in front, and prevent any annoyance in rear, but occasionally casting a very suspicious look over his shoulder, and, I suspect, deteeted Lyall or myself getting too near. I was within shot, and waited only for a clear view of him, when le backed to the summit and clearly saw me. He also was evidently up to our tactics: bolting down, and keeping the hummock between us, was far away before I was able to regain sight of him. Punch followed, giving tongue enough to frighten all the bears in this region. We retreated, and right glad was I to get back; these excursions, after ten hours' travel, take the courage down amazingly. Punch made the circuit of the island, coming in quite as much refreshed as if he had stolen another mass of pemmican. Fine gentlemanly brced, those Cape York dogs !-proud as Lucifer. Our plaee of encampment exhibited traces of three bears, - male, female, 
and eub,-who had very inquisitively searehed the premises. It is probable, if we had been less offensive and taken the matter quietly, that they might lave revisited us today. Punch got half my supper, to make up for his disappointment.

June 15.--The day tumed out gloomy: 110 sum at noon, with temperature at $25^{\circ}$, by which we lose this as a rating position, now however unimportant. As no signs of Grove could as yet be traeed, at six P.м. the sledges were ordered to meet me on the south side of the island, and, taking two men to carry instruments, I travelled over the summit, which eommanded a more extensive view. Independent of Mr. Grove, I began to feel some alarm at the non-appcarance of the two men despatched, as well as for our provision; but on one point I felt assured, as by my orders left with Mr. Allard he would be detained, "to await the return of Dr. Lyall." The temperature rose to $36^{\circ}$, moist, and thawing r'apidly, yet the eold was more sensibly felt: the near floe exhibited a rent eighteen inches wide, and the water rose in the fissure within nine inches of the upper surface of the iee; any move therefore must earry all this iee off-shore.

June 16.--On reaching the island erest I pereeived a tent pitehed on the opposite shore, and two men, one of whom was in the act of erossing to our sledges. On regaining the boat I reecived a note from Mr. Allard; he had misconeeived my orders entirely, - taken Mr. Grove to the ship, leaving the two men in eharge of spinits, a gum, and ammunition, and who could be surprised?--one had eseaped unhurt by the bursting of the Fudson Bay gim! Independent of my written orders, finally allotting Mr. Grove to this duty, Mr. Loney had verbally ex- 
plained it to the leading man, the ship's cook: however, on we pushed for the tents, packed, and departed. It was a great disappointment, as I had intended sending Dr. Lyall and Mr. Grove up the Great Valley, between this and Vall Bhuff, where I intended remaining, or possibly moving on to Star Bluff : they would have enjoyed the opportumity of good sport, and probably have met with herds of musk-oxen, which we were now satisfied were not searee here, as these men notieed three, and probably they would have been taken had any sensible person been present; however, all was now deranged, and it only remained for us to make good the positions lying in our homeward ronte. Before reaching the depôt (laid out by Mr. Loney in April) we notieed two deer, but they proved too wary for our eager sportsmen.

Shortly after midnight on the 18th we eneamped at the Station. Mr. Allard had left a note, by whieh I learned that he only quitted on the 13th. The weather elearing off and a bright sun aiding, I aseended the high land in rear, expeeting to obtain a great range; but the haze resnlting from heat destroyed my hopes, and I returned unsueeessful. I waited for the sun at noon, but as it did not seem inelined to show out, I strolled along the land in search of fossils, whieh were very abundant, espeeially one or two varieties of madreporite, which were here strewed in patches as if they had formed a sul)marine garden! Beyond, to searard, the open spaces of water were pretty well stocked with eider-duck and brent-geese, whieh occasionally flew elose over our heads; but, with the miserable fowling-picees we lad, killing was an achievement rarely awarded to our exertions. 
About 6.15 on the 18 th of June we continued our journey, which, from the rotten state of the ice, was confined to the coast-line or across the gravel spits or ledges, now denuded of snow and ice, and which appeared at a former period to liave barred the mouth of some great estuary within, where, from our higher stations, very considerable lakes had been observed. These spits, in radii from the great embouchure of the valley or river, are rather puzzling, inasmuch as within our own observation no river force has been noticed, and I verily believe has not existed for years, or perhaps ages; indeed reason is opposed to any such fact : if any such force, as such appearanees would indieate, had been in action, all the iec must have been speedily washed away. During the last season I know that, in three positions, no liver foree was in action up to the first wcek in September; I can only therefore refer these appearances to that distant epoch when perhaps the whales and other objects were deposited on clevations of five lundred feet and upwards, and other extraordinary influences were exercised throughout these regions. Whatever those disturbances were, they were not momentary. The summits of these mountain ranges were probably submerged; the subsidences or parallels bear the impress of distinct periods of particular action, spread possibly over ages, and are most beautifully defined throughout this Aretie region by similarity of action or of the successive retirement of the ocenn; and it is only by referring to such stupendous movements of Nature that I can at all recognize adequate forces to denude, to gully out, and cut such vist watercourses. I to not allude to trumpery valley gushets, 
r'muning over and leaving undisturbed or ummarked the angular fiagments of soft limestone, but of vast fluviatile contimued agency, rolling to the seaboard masses rounded by attrition, and leaving behind the impression that lece a mighty river rolled impetuous into the ocean, and now, having ceased, leares us to wonder how these stomes, even ehalcedonies, rounded and polished, oceur in the frozen river-beds! 'Tlicse are especially obscrvable between Mount Parker and Step Mount; and in the interval of ten miles, where now scarce a rivulet can be found, I cannot but believe that a great river played its part, and left. the extensive mud-flats and gravel ridges which now occupy our attention. At present it is to be doubted if the short interval of summer would even furnish a rippling brook. But we cannot stop here: rivers and gुullies are not alone concerned; by their courses the water doubtless escaped, but by what cause was every mountain of these northern ranges reduced to certain parallel strata, as regards the lines of upheaving or subsidence? - for the lines of stratifieation themselves of the roeks (generally magnesian limestonc), although presenting horizontal appearanecs cast and west, are invariably dipping slightly, say at $5^{\circ}$, to the northward. Nor is it alone that these peculiar terraces strike the observer; the level surfaces of mountain summits, as well as gentle slopes, are for miles, indeed wherever visited, found to present an even surface of fincly Maeadamized fragments, to the senses, ploughed, harrowed, bush-harrowed, or fincly swept! and, in some instances, the marks so indelibly impressed as if it had been the aet of yesterday!

Another question forces itself on the mind: is it not 
strange that these carcases or bones of whales should prefer elevations of eighty or five hundred feet? Why are they not in the valley bottoms? To comprehend all this, in all its apparent freshness, the mind becomes painfully engaged. There is no acting cause now, and yet we have had two fine seasons; there are no purling streams, and yet the momtain-sides are bared from snow. But as to snow, to our conception that plays but a minor part; for truly, so to speak, the hills are never "snowclad;" the fall of a few days is disperserl in a few loours, and the last galc preceding actual winter puts an end to further lieary falls of snow, by reason of extraordinary low temperatures; it falls as ice or rime, no longer flocenlent; indeed, what we generally misname snow is truly, perhaps, drift ice.

At length we are driven to ask those who would find reasons of their own for many things less intelligible, By what course of events, at what epochs, did thesc highly interesting appearances occur; not confined simply to the spot before us, but continuous from hence to the moutl of Lancaster Sound, and, except the off-lying islands of Exmouth, North Cornwall, and the Victoria Archipelago, etc., pervading all this northern region?

At this moment another perplexing circumstance must not be lost sight of. As yet we scarcely admit the existence of a gale: we certainly have not experienced the fierce ravages of tempests or hurricanes: we have the other extreme-intense cold and calm; these two must coexist! the breeze and intense cold, or the minimum of $-625^{\circ}$, have not yet been experienced. Where no rains or torrents can prevail, unless under a temperature 
less than congelation, the great disturbing forees are absent; snow falls harmlessly, serving possibly as a mantle to proteet the picture; frost seals it. Under sueh action, and with short glimpses of sunmer, the faee of the hills today may be that to eternity: let him who is eompetcnt break the seal and enlighten us.

Under the present aspeet of the coast about us, solemn indeed is the feeling as regards our missing eountrymen : no hope here, so far as our experience serves, can exist for sustenanee beyond the casual capture of bear or fox during six montlis of the season, and no means of allaying thirst but by thawing iee in the mouth until June, perhaps July, then only perhaps for six weeks.

As regards the surface disturbanees throughont these regions, I am far from allowing iec to be the agent. In warmer rcgions masses of roek are dislupted, beeause water enters the crevices, is frozen, and ronds them: heat drives off the iee entirely; here no such aetion takes plaee; masses of roek however are disrupted from their deep beds, and rise in eonfused heaps upon many rounded hills, where the piek, even in the warmest summer day, would not penetrate many inehes without being opposed by a solid mass of iee and stone, defying further progress. The surfaec heat of some few warm hours (few and far bctween) would not penetrate one foot; and eren admitting suel a faet, for argumcnt sake, the result would be merely adding a fresh iey eorering until renewed heat entailed a similar repetition. This we experienced repcatedly during the whole summer season, rendering it diffieult to dig a hole any deptlı; but if the simple mode of disintegration by frost be advaneed, 
let us inquirc whether such an explanation will satisfy our seruples as to the mixture of so many ingredients, and of many never found in situ: will frost bring them together? I wonld venture to submit a few interesting questions for solution : in the first place, how did the rubble on the momtains and sides become reduced to Macadamized proportions, not affording, for hundreds of yards, one stone wcighing above one pound? At what period were the skeletons of whales deposited? When did trees or vegetation flourish here? If these seas were ever open, where is the drift-wood, or why are the small pieces found of the oldest possible date? These are matters for the discussion of master minds; they afford fair grounds for reasoning, and may prove highly interesting to science.

Except at our extreme eastern position and Arthur's Strait, no trace of Lsquimanx has been noticed; still I am inclined to believe that their visits to this northern region have been comparatively recent.

In our progress towards Step Bluff, three deer were noticed. Dr. Lyall, accompanied by two of our best sportsmen, attempted to creep towards them, but they proved too wary, and made off up the valley. We were now pushing for Step Bluff, the north-west angle of Prince Albert land, and the extreme discovery of last season. Several troublesome spits rendered travelling very laborious, the sharp angular stones cutting deeply into the soft iron of the l'umner bands, as well as tearing out the rivets. As we neared our position, greater difficulties howcver assailed us; the heat lind sufficient influence on the inclined dark detritus from the mountain above us to 
melt the remaining portions of snow, and thus produce a belt of water within the skirting ice, which opposed great diffieulty to our advance, notwithstanding our light loads and doublc-manning the sledges.

The travel withont wading now beeame very diffieult; and thinking I might avoid the diffieulties by erossing the ravine about a hundred yards up the hill-side, I made the attempt. But I found the soil fluid, and so quick, that in my weak state it was unsafe to risk being cntrapped: even the light dogs declined the effort. Ascending however until I gained the old snow, I suceeeded in finding a place pretty well bridged, which enabled me to clear the rmaining difficulties. If such bc the condition of the coast-line in June, what must be expeeted in July and August? The floe was no longer safe, and a few hours might place us in the awkward dilemma of not being able to advance until it broke up. Not a day had we to spare, and therefore it was neeessary to exert every effort to reach the turn of the land before the ice became detached.

June 19.-As we neared Step Bluff (now named Cape Ogle), the road improved, and about two A.M., having reached the shingle beach which fringed the coast-line, we pitehed. The day was bright, the horizon clear, and all the objects we were anxious to see were clearly defined; and this being our connecting, or key station, I lost no time in gaining the summit. Indeed I had becomc so weak, and anxious to relieve myself from further fatigne, that I lad preceded the party, hoping to terminatc my labours. But I was doomed to meet with disappointment: beforc the instrument could be le- 
velled, a densc curtain of fog eapped the mountain. At intervals the bright sum dispelled the vapours in particular directions, and permitted the most important distant points to be taken. But I was not easily disconraged; and, determined to wait the pleasure of Damc Nature, made up my mind to try her humours, at least for twelve hours. Adopting a wateh, I directed my meals to bc sent up, and a spirit-lamp to warm tea, cocoa, ete.

From this commanding elevation (about cight hundred fect) I had a good view of the changes which had occurred. The water had made in great detached pools between us and Exmouth Island; indeed some spaces afforded sufficient area to manœuvre the Arctic Squadron. Immediately beneath the base of our cliff, and continuous to Star Bluff (about six miles), the ice had broken off abruptly from the shore ice, leaving a vertical glacier face of ten or fiftecn fect, and within this only was travel practicable. The boat certainly could pass; but the launching, hanling-up, lading and unlading, rendered this mode of travel injudicious, as well as inscenre: it would further cause infinite delay, and at this moment could not be risked.

In the water beneath, but preserving a vcry respectful distance, we noticed muncrous brent-geese, eiderduck, gulls, kittiwakes, and mollymoks, which our crews were very anxious to try their luek with in the boat; but too much rotten ice intervened, and, with the heavy load of provision we were now burdened with, it was pecnliarly neccssary to husband strength and avoid risk.

Inland in the valley gorge between this and Depôt Station, a vast lake communication appears to penetrate 
about five miles to the south-east; and from the steeply inclined sides of the mountains, a very considerable water surface must prevail. If musk-oxen, deer, or other game exist anywhere in this region, I should be greatly inclined to seek for them there, and the attempt may yet be made from the ship.

The entire formation of this headland is a fossiliferous grey limestone, with a tendeney to oolite, comminuted as usual into four-ounce pieces. Whence the larger lumps were obtained to construct the caim, I know not, unless they cleared the monntain before our arrival: Commander Richards was unable last scason to find morc than crough to construet his very small mark.

Making a tcmporary bed of the smoothest Maeadamized spot, I lay down under the lee of the pile, in order to avoid the barber, or condensation and freezing of fog on eyebrows, whiskers, and beard, redueing one literally to Jack Frost, very troublesome and very painful to remove. I happened to drop into a momentary doze, when my watehman pulled me by the coat, and on opening my eyes I noticed before me, in my confused state, a fairy-like vision. About thirty yards in front of me sat, with body and ears erect and fore-paws hanging, a most interesting, inquisitive, snow-white hare. Although in some measure disposed to pity the poor creature, the eruel instinct of our nature prompted me to point my gun, and fire a ball; and this failing, shot followed; but the vision, much to our mortifieation, vanished. One brent-goose we had, to which this would have been an agreeable addition. But Puss, and many other speeimens of Aretic zoology, may thank our bad fowling-piees for similar eseapes 
from the National Museums. Events seldom oeeur singly : I had not moved from my soft gravel bed, having rcloaded, when two other furred animals eame to inquire the eause of disturbance: one literally ran into my hand, and the other was taken by my attendant. These were two fine specimens of lemming, mueh resembling moles, Samntering about, I found, on the very edge of the preeipiee, a very large vertebra of whale, whieh I have since discovered to have been carried up the mount last season by some of Commander Richards's party for a mark. Deseending to the beach to determine the latitnde, whieh I found to be $77^{\circ} 3^{\prime} \mathrm{N}$., I eontinued sauntering about this flat, examining the variety of mineral bodies and fossils here collceted and freed from their matrix; not varying, however, from those of Depôt Point, exeepting that the madreporites here more frequently presented the chalccdony or flinty statc. On reaching the pile erceted here, I remarked three other vertebræ, mueh larger and very different to that on the eliff, these having their projecting processes completc, and of a dark, dirty greenislı colour; that noticed at the summit was mueh bleached. The temperature, under a very oppressive sun, ranged between $28^{\circ}$ and $32^{\circ}$ in the shade, the water still making, and iee off-shore in motion. Abont two (having maintained myself independent in the boat since the return of the tent) I endeavonred to recover some of the lost sleep, but without sneeess; and at four P.M. conmenced our lower beacon, removing or construeting a duplieate further out, in eomneetion with the mark seen at the base of Star Bluff.

dune 20.-(Six г.м., temp. 28\%.) We now pushed for- 
ward, and had very intrieate travelling; the snow-bank observing the inclination of the détris, throwing all the weight on the lower runucr, and imbedding it in sneh a manner that, with all hands and very great labour, it was diffieult to make any progress. After mastering two miles of this dishcartening work we again reached a flat beach, following up the tracks of our returning sledges, the 'Dauntless,' ete. The bay eontained between this and Star Bluff was evidently the great outlet of somc extensive lakes, possibly those before alluded to ; but its course here was bounded inland for two miles at least by vertieal bluffs, extending from Star Bluff, and on the north by high level terraees, swept away at their base by the force of the waters. Thrce distinet embouchures, with beds of rounded stones and oeeasional boulders, presented; but not one drop of water! About eleven

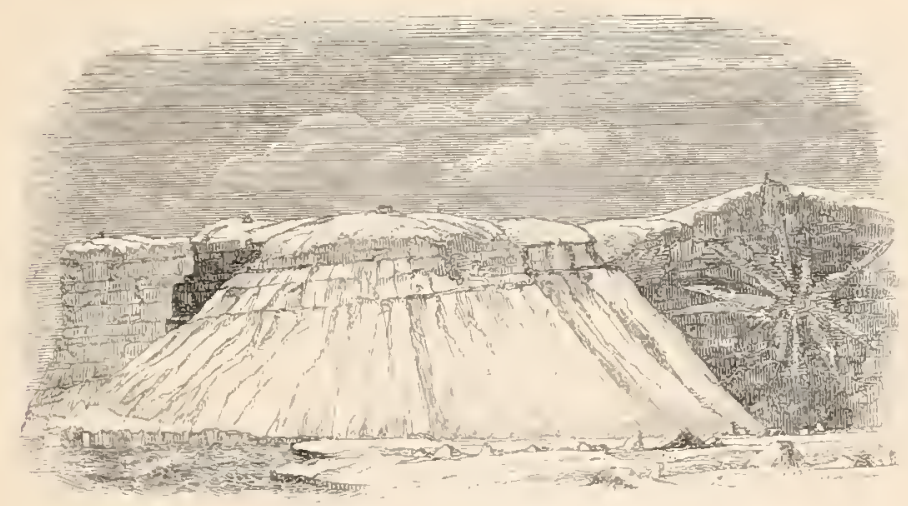

we reached the depot on Star Bluff, not named from any propitious star, because I here took my involuntary C.B. (cold bath), and here was deposited our damaged bread, 
as well as additional supplies, whieh we now wished at the ship. Star Bhuff (now named, in compliment to my old eaptain, Cape Ekins) takes its name from a curious arrangement in the fracture of the eliff face, which observed a radiated form; the snow, lodging on the ledges, presented against the dark ground, elsewhere prevailing, a very perfeet stellar form, * used by us for a long time, and at great distances, as a mark.

Here we found that the greater part of the provision remained, and we had therefore to overload our sledges and earry it forward. It was umpleasant, and not quite fair to our erew; but delay would make matters worse: it was therefore to be executed, even with our larassed crews; every one was disconcerted, and very dark were our faees. During this proeess I ascended the hill, where I had ordered a eairn to be built; possibly it was deemed too steep for younger blood: we built three, one a house, the two others were constructed by myself,- - the last being on the inaccessible summit of 'True Star Bluff, -and unattended. I must say I would not have ordered it to be done by any but a volunteer.

It is needless to repeat another Step Bluff version : we pushed on, making very slow work, and pitehed at a low rubbly point, about five miles in advance. We lave now been fifty days engaged at this work, with fair sportsmen and three good private guns, besides two indifferent Govermment fowling-piees; and two hares, five ptarmigan, one brent-goose, and several plover, not one day's provision, is our list of game taken. The race past Cape Ekins was rapid, with overfalls; the water abounded with wild-

* The woorlcut is more decidedly stellar than the reality. 
fowl, but that was all we benefited by this "tecming of animal life." I think it possible, had we lamehed the boat, that four or five ducks might lave been killed; they were all very wary and strong on the wing. How ten men, dependent on their guns, could subsist, I cannot imagine; if travelling, it would be next to impossible. Walrus or bear, if the party was stationary, would afford fuel and food; and, during the season, the skins of both, aided by snow luts, might furnish a miscrable shelter: the frozen skin of the wal'us would be impenetrable, and the fat could be peeled off as required. How many would survive such a life I venture not to surmise.

At midnight on the 22nd we reached Depôt Bay. I was on the heights, obtaining angles, when I observerl both sledges, having entered well on the floe, simultaneously turn back: there certainly was open water not far from them, but as both our return sledges could not be much in advance, and we were on their track, I hastencd down, and, on reaching them, found that mercly surface water had alarmed them. Having extricated the sledges, we double-manned then altcrnately, and soon surmounted the difficulty, occasionally sinking into the holes, where surface pools harl frozen, about knce-rleep; but this I knew must be expected just at this season, the true base of the floe having a thickness of at least three feet ice: no accirlent or truly "break in" oceured.

We now pushed forward for a low spit island, in the depth of Napier Bay, in which direction I noticed a sledge advancing under canvas: this was hauled up at the spit, and her crew advaneed to aid our party. It proved to be Lientenant Cheyne, despateherl by Lien- 
tenant May, who had returned to the ship on the 13th of June, and was the bearer of intelligence from Commander Richards, who had fallen in witl Lieutenant Hamilton, of the 'Resolute,' by ehanee, about one hundred miles west of the appointed rendezvons, to which he was then proeeeding. Fortunately, Commander Richards was thus enabled to direet Lieutenant Hamilton where to overtake Licutenant Osborn, who was also instrueted to eonduet him to the rendezvous. Lieutenant Osborn was further direeted to forward the doemments brought by Lieutenant Hamilton, by Lieutenant May, who had thus, on reaching the ship, again despatehed them by fresh liands to meet me: the eontents of these despatehes will be treated on in the following ehapter.

Leaving Mr. Cheyne to assist the other parties, after a short rest at this spit island, I pushed on for the ship, with two days' provision: on our outward journey it took three days to get thus far, but now, using the 'Hamilton' as a sledge under eanvas, we reached Village Point in four hours, viz. about 9.30 P.м.

Having delayed a slort time to obtain some angles, I was in the act of setting up the theodolite: an ominous jarring behind me eaused me to start and leap aside with the instrument ; providentially I eseaped. This pile, eonstrueted of very large stones, fell with a heavy erash on the spot I had ocenpied; it was twelve feet at base by ten feet high, and flat-topped, to support an instrument.

The work finished, onward we pushed, and at five P.M. On the 23rd of June, ten hours only from the time of starting, I was divesting myself, before a warm fire in my cabin, of my travelling dress. 


\section{CHAP'TER XIII.}

Open Mater.-Despatch from Pichards.-Notice left by M'Clure.Stores covered with Snow.-Brewing.-Mustard and Cress.-Keturn of Richards.-Morements of Western Division.-Game killed. -Canal completed.-Caim on Barrow Tsland.-Osborn rejoins.Mount Acland.-Assistance Spit.-Visit of Pullen.-Port Refuge.

THE great surfaees of open water which I had observed to the northward, added to rumours of the appearanee of a similar inclination in the vieinity of the ship, rendered me very anxious to be present, in order to superintend in person any measures which might be expedient for the relief of the sonthern parties, which might be expeeted about the 13th of July; but I was mueh relieved, on arriving at Village Point, to find, by the open water there, that these matters had been very mueh overrated, and that nearly the same area of water remained as notieed on the 2nd of May; at whieh date also the iee had manifested similar symptoms off the sonthern end of the sound, towards Spit Island.

The passage of the Queen's Channel has doubtless been in a similar eondition for some time, and attended with danger; but before the period arrives for the final erossing of our party, they will be aided by open water 
and their two boats. On examining the immer chammel ice, it was found, in the tideway, where many holes existed, to average two feet in thickness.

The Larly Fanny Disco* was despatehed (in licu of a carrier-pigeon) to the ship, adorned with a yellow flannel neeklace, within the folds of which a note to my steward was seeured, directing him to make the necessary preparations for my return : this trust she frithfully cxecuted. But her poor companion, Mr. Neptume, having been drummed out and declared by all the sledge erews as a notorious penmican thicf, had committed suicide by attempting to stcal tlie bait of a spring-gun set for the wolf which had followed our dogs up to the ship: 110 one had yet succeded in capturing one of these animals.

I now proeecd to explain the nature of the despatcl received from Commander Richards, and the circumstances attending his meeting with Lientenant Hamilton. Alluding to Licutenant Osborn he observes :-

"We parted on the evening of the 17th of May, and on the morning of the 18 th, stecring at the time to the north-westward, I discovered sledge tracks, apparently very recent. Halting the sledge, I proceeded with two of my erew to follow them up, and in the eourse of an hour came upon the encampment, which proved to be a party under Lieutenant Hamilton, twenty-one days absent from the 'Resolute;' we must have passed each other' within one mile, but the thick weather, had it not been for the sledge tracks, would have prevented our meeting.

"From Lieutenant IIamilton I learned that H.M.S. Resolute and Intrepid had reached Winter Harbour,

* One of the dogs, so named by the men. 
1S53.] NOTICE LEFT BY COMMANDER M'CLURE. 331

Melville Island, but finding it hampered by ice, had wintered at Dealy Island, Bridport Inlet. That Licutenant Necham, on his return last scason from the duty of laying out the depots, had fortunatcly discovered a record lcft by Commander M'Clure at the Sandstonc Rock, in Parry's Winter Harbour, stating that H.M.S. Investigator had been blocked for threc winters in the icc, at the " Harbour of Mercy," Banks Land. Captain Kellett conscquently had despatched a travelling party to the 'Investigator' in the early spring, and Commander $\mathrm{II}$ 'Clure succecded in reaching the 'Resolute' on the 19th of April. The 'Investigator' had lost onc man since entering the ice."

The following is a copy of the document left by Comsmander $\mathrm{MI}^{\circ}$ Clure :-

Abstract of the Proceedings of Her Britannic Majesty's Discovery Ship

'Investigator,' since parting company wille the 'Herald,' upon the 31 st July, 1S50, off Cape Lisbourne.

August 2, 1850.-5.20 A.M., lat. $72^{\circ} 1^{\prime} \mathrm{N}$., long. $166^{\circ} 12^{\prime} \mathrm{W}$. Made the ice, which did not appear heary; but upon cntering it a short distance was undeceired, and ran out.

August 5.- In rumning along the pack edge, endcarouring to find an opcning, exchanged numbers with the 'Plover,' and at 11 A.s. made a low shingle beach to the eastward of Wainwright Inlet, and at midnight rounded l'oint Barrow in 73 fathoms, but from the foggy state of the meather did not see it.

August S.-1.to A.M., being off Point Drew, sent Mr. Count, Second Master, and Mrr. Miertsching, interpreter, to deposit a notice of our having passed, who met some Esqumaux that had arrired three days previous. Thesc trade with the Russians, and were very friendly: therefore sent a lctter, with the chance of its reaching the Admiralty. We also heard from them that last ycar threc boats had passed to the eastward, with white men and Indians, which was most probably Lientenant Pullen. In the evcning creeted a cairn, and bmied another notice at Point Pitt. 
August 9.-Passed the Colville, about forty miles from its entrance, in three fathoms and a half.

August 11.-Deposited a notice upon Jones's Island, which was thickly strewed with drift wood; in the forenoon two baidars, containing twenty-four uatives, came alongside. The ehief possessed a gun, with "Barnet, 18+0," on the lock, obtained from the Russians. Bartered tobaeeo for salmon and ducks. In the afternoon eommunicated with another party, who were exceedingly iutelligent and clean. Sent despatches for the Admiralty, via Colville, and from what the interpreter states, bclieve that they will arrive.

August 12.- Several baidars cane alongside, received fish and dueks for presents of beads and tobaceo; these are adroit pilferers. Ran upon a shoal eight miles north of Iarborough Inlet, laving, during the last two days, narowly cscaped several of these dangerous banks, which are very little above the water, and hidden from view by the iee. Hove ofl with streau anehor, but unfortumately upset a whale-boat, and lost eleven casks of beef, having to eary sail to preveut being again set on shore.

August 15.-Found it impractieable to get two miles in any direetiou, the iee having closed from the northward, resting on the shoals in that direction, and to the sonthward on the low banks which we grounded upon yesterday. Anchored to await some favourable ehange.

August 16.-Ice to northward of shoals having slightly eased, leaving about a hundred and fifty yards of open water; reighed, and warped through two eables' length of ice to get into it, which occupied six hours of hard labour, so heavy was the pack.

August 17.-Noon. The weather, which had been fogoy, eleared, with a breeze from the north-east, made sail through heary sailing icc, occasionally striking violeutly. Navigation along this coast very dangerous, the sand-banks being low and numerous. Lat. $70^{\circ} 30^{\prime} \mathrm{N}$., long. $145^{\circ} 4^{\prime} \mathrm{W}$.

August 21.-Made the Pelly lslands, of the Mackenzie; since the 17 th have encountered very heavy icc; ran ninety miles iuto a bight, which brought us to the solid pack: fortumately we werc enabled to run out of it before it closed.

August 24.-Observed some hints a little to the westward of Point Warren; sent despatches for the Admiralty, with the hopes of their being forwarded by the Hudson's Bay Company. This tribe however lave no traffic with them, but barter with others further west that trade with the Colville, giving as their reasons, that the Hudson's Bay 
Company had given the Indians water which had killed many of them, and that they did not wish to have any; they appear savage and warlike, and are at enmity with their neighbours. Brought the despatehes back.

August 30.-Observing a post crected on the beach near Point Maitland in Liverpool Bay, sent to examine it, and deposit a notice of our passing; found it was an Esquinaux' mark, who apparently lad reeently quitted it, there being several caches eontaining birds and fish. In the afternoon, whilst approaching Cape Bathurst, observed Esquimaux on the shore; upon eommmnicating with them found that they belonged to a tribe now at Cape Bathurst, who were catching whales, and the same who had seen Sir John Richardson last year. In the evening, being thiek, and getting into three and a half fathoms, anchored between Baillie's Island and the main.

August 31.-W'roeeeding to Cape Bathurst; tribe consisted of three hundred, rery fricndly, would go south in three weeks; gave them despatehes for the Admiralty, a gun and ammunition to the chicf, and many presents among them, and, judging from their clcanly appearance, have great expectation of their reaching.

September 1.-Off Cape Bathurst; many natives came on board, and being nearly ealm, remained until evening, when a brecze springing up, we took our final leave of the Esquimaux on the American coast, fully convinced that neither the ships nor any of the erews of Sir John Franklin's Expedition have ever reached these shores. They appear a quiet, inoffensive people (with the exeeption of those at Point Warren, which the Cape Bathurst tribe have no dealings with), and would assist any white people thrown amongst them. The whole of this coast is shallow, but with the lead may be safely navigated, the soundings being rery regular: the shoals terminate about thirty miles to the castward of Yarborough Inlet, and water varying from one nile to forty in breadth may be calculated upon along shore, between the beginning of August aud 10th of September, aecording to the winds, more or less ice encumbered; but the natives state that crery year the ice opens from the shore. Te found the prevailing winds from east-south-east to north-east.

September 6.-11.30 A.M.; being to the northward of Cape Parry, remarked high land from north and east to enst-north-east.

September 7.-9.30 A.M., landed, and took possession of the discorery, and named it Baring lshand. The land is bold upon the southern side, being upwards of one thousand fect in height, its northern being 
Banks Land. Ereeted a signal pole with black ball, and left a notice, in lat. $71^{\circ} 8^{\circ} \mathrm{N}$, long. $122^{\circ} 48^{\circ} \mathrm{W}$.

September 9.-Observed land north-north-east; named it Prince Albert's Land, whieh is eontinuons with Wollaston and Victoria Land, and extends north to lat. $73^{\circ} 24^{\prime} \mathrm{N}$., long. $112^{\circ} 4 \mathrm{~S}^{\prime} \mathrm{W}$.

Septcmber 11.- Ship beset, lat. $72^{\circ} 52^{\prime} \mathrm{N}$., long. $117^{\circ} 3^{\prime} \mathrm{W}$., but ice in motion.

October 8. - Sinee the 11th of last month have been drifting in the paek; narrowly escaped destruction several times, until, with a heavy mip, at three A.M., which listed the ship $3 \frac{1}{4}^{\circ}$, we were firmly fixed for the spaee of nime months in lat. $72^{\circ} 47^{\prime} \mathrm{N}$., long. $117^{\circ} 34^{\prime} \mathrm{IV}$.

Octoler 10.-Took possession of Prinee Albert's Land, distant four miles.

October 15.-And, today, of the Prineess Royal Isles, lying in the eentre of Prince of Wales Strait, distant fom miles from the ship (lat. $72^{\circ} 46^{\prime} \mathrm{X}$., long. $117^{\circ} 44^{\prime} \mathrm{W}$.). There is erected a large eairn, pole, and ball upon its smmmit; and have deposited three months' provisions for sixty-six men, besides leaving a boat and some ammunition.

October 21.-The Captain, MIr. Court, and party, started to traec this Strait towards north-enst.

Octobcr 26.-Discovered the entrance into Barrow Strait, in lat. $73^{\circ}$ $30^{\prime} \mathrm{N}$., long. $11 t^{\circ} 1 t^{\prime} \mathrm{W}$., which estabhishes the existence of a northwest passage.

October 30.-Five musk-oxen shot npon P'rince Albert's Land, which terminates our operations for 1850 .

April 15, 1851. -This day despatehed three travelling parties to search the eoast hine: Lientenant IIaswell to south-east, towards Wollaston Land; Lientenant Cresswell in dineetion of Banks Land; and Mx. Wynniatt, Nate, to north-east; who respectively reached the positions as noted in the margin, and traced the coast as per accompanying ehart.

Captain and Mr. Niertsehing, the interpreter, communieated with the Esquimax upon Prince Albert's Land, abont sixty miles south of oun position, who had previonsly been met by Lientenant Haswell. They traced the coast-lime as marked in the chart, and state that there are many of their tribes inhabiting the land towards the sonth, but that they know of none to the northward; they are a kind, simple people, and have never beforc scen the white man, at whom they were evidently alanmed.

July 14.-Ice opened without any pressure, and the ressel was 
again fairly atloat,-but so surrounded with it that we only drifted with the pack, haring becu able to use our sails but twice, and then only for a few liours, up to the 1th of lugust, when we attained our funthest northern position in Prince of Wales Strait, lat. $73^{\circ} 14^{\prime} \mathrm{N}$, long. $115^{\circ} 32^{\prime} 30^{\prime \prime} \mathrm{W}$.

August 16.-Finding our passage into Barrow Strait obstructed by north-east winds, setting lare masses of iee to the southward, which had drifted the ship fifteen miles in that direction during the last twelre hours, bove up to rm to the sonthward of Baring lsland.

Augusl 20.-Lat. $74^{\circ} 27^{\prime} \mathrm{N}$., long. $122^{\circ} 32^{\prime} \mathrm{W}$.; lave had clear water to reaeh thus far, running within a mile of the eoast the whole distance, when our progress was imperled by the iee resting upon the shore. Secured to a large gromded floe picee in twelve fathoms; iee appears to latve been but reeently detached from the coast.

August 29.-Ship in great danger of being erushed or driven on shore, by the ice coming in with heavy pressure from the Polar Seal, driving her along within one hundred yards of the land for half a mile, heeling her $15^{\circ}$, and raising her bodily one foot eight inehes, when we again became stationary, anc the ice quict.

Seplember 10.- - lee again in motion, and ship driven from the land into the main pack, with hcary gale from south-west. Snceeeder in getting clear from main pack, and secured to a large grounded floe, lat. $74^{\circ} 29^{\prime} \mathrm{N}$., long. $122^{\circ} 20^{\prime} \mathrm{T}$.

September 19.-Clear water along shore to eastward: east off, and worked in that direction, with oceasional obstructions and several narrow eseapes from the stmpendous Polar ice, until the evening of the 2:3rd, when we ran upon a mul-bank, having six feet moder the bow and five fathoms asterm; hove of mithont sustaining any damage.

September 2t.-Daylight, observed Barrow Strait full of ice, and large masses setting into the bay; cletermined on making this our winter-quarters, and finding a well-sheltered spot upon the sonth end of the shoal npon which we last night grounded, ran in and anchored in four fathoms, lat. $7 t^{\circ} 6^{\prime} \mathrm{N}$., long. $117^{\circ} 5 t^{\prime} \mathrm{II}$. This night were frozen in, and have not since mored. The position is most execllent, being well proteeted from the heary ice by the projection of the reef, whieh trnows it clear of the ship six hundred yards.

The cimrents along the coast of the Polar Sea appear to be influeneed in their direction, more or less, by the winds; but certainly on the west sidc of Baring lsland there is a permaucnt set to the eastward; at one time we found it as much as two knots during a perfect calm, and 
that the flood-tide sets fiom the westward we have ascertained beyond a doubt, as the opportunitics afforded during our detention along the western shore of this island gave ample proof.

The prevailing winds along the American shore and the Prince of Wales Strait we found to be north-east, but upon this coast southsonth-west to north-west. A ship stands no chance of getting to the westward by entering the Polar Sea; the water along shore being very narrow and wind contrary, and the pack impenetrable but through Prince of Wales Strait, and by keeping along the American coast I consider it practicable.

Drift-wood is in great abundance upon the east coast of Prince of Wales Strait, and on the American shore also. Much game abounds. In this vicinity the hills abound in reindeer and hare, which remain the entire winter. The have becn very fortunate in procuring npwards of fom thousand pounds.

The health of the crew has been and still continues excellent, without any diminution of numbers: nor have we felt the slightest trace of scurvy.

It is my intention, if possible, to return to England this season, touching at Melville Island and Port Lcopold; but should we not be again heard of, in all probability we shall have been carried into the Polar pack, or to the westward of Melville Island: in either of which iny attempt to send succour would only be to increase the cvil, as any ship that cuters the Polar pack must be inevitably crushed; therefore a depôt of provisions, or a ship at Winter Harbour, is the best and only certainty for the safety of the surviving crews.

No traces whatever have been met with, nol auy information obtained from the natives, which could by any possibility lead to the supposition that Sir John Franklin's Expedition, or any of his crew, have ever reached the shores we have visited or searched; nor have we been more fortunate with respect to the 'Enterprise,' not having seen her since parting company at the Strait of Magellan on the 20th of April, 1850.

This notice was deposited by a travelling party in April, 1852, consisting of

Captain M'Clume, Mr. CourT, Second Master.

John Calder, Captain Forecastle.

Sergeant Woon, R.M.

George Gibis, $A b$. 


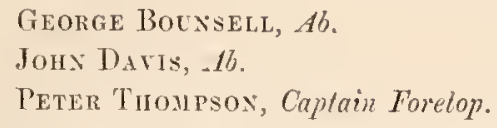

Whoever finds this, it is requested it may be forwarded to the Secretary of the Adminalty.

Dated on board Her Britannic Majesty's Ship

'Incestigator,' frozen in in the Bay of

Mercy, lat. $7 t^{\circ} 6^{\prime} \mathrm{N}$., long. $117^{\circ} 54^{\prime} \mathrm{II}$.-

April 12, 1552 .

(Signerl) Robert M Cinte, Commander.

Unless there is a ressel now at Melville Island, it is not my intention to revisit it, but make the best of my way down the Strait.

$$
\text { (Signed) Robert MCCLuRe, Commander. }
$$

'Resolute,' Dealy Island, April 27, 1853.

Found 'Inrestigator' at Bay of Merey (haring lost one man since entering the ice), by a travelling party from 'Resolute, that left the ship on March 10, 1853. Captain M'Clure anned on board this ship on April 19. Detailed accounts will be sent to Beechey Island. She has not met with any traces of missing Expedition.

II. Kellett.

Commander Richards continues :-_" I also learned from Lieutenant Hamilton that Commander MrClintock had left the Hecla and Griper Gulf carly in April, to carry ont the search to thic westward.

"It would therefore have been worse than uscless for me, under these circumstances, to follow ont my original intentions. And considering that it would be for the benefit of the service that I communicated with Captain Kellett, inasmuch as it would enable me to bring you his despatches, the latest intclligence of what had been effected by his parties, as well as the determination which had been comc to as to the alrandonment of the 'Investigator,' I resolved at once on this step, and to return by 
the sonthern coast of Melville Island, and up the Byam Martin Chamnel. Direeting Lieutenant Hamilton to the rendezvous for your despatehes, and desiring him to endeavour to overtake Lientenant Oshorn, and deliver to him Commander Ml'Clure's journal, we parted without loss of time."

But let us now revert to the 'Assistance.' Many ehanges had oceurred; but one idea prevailed,- that she had exchanged her snow-white bath for the semblanee of a filthy farm-yard: I could barely eredit my senses.

The deeided aetion of the tides now furnished undoubted proof of the release from ontward floe pressnre by the inereased gaping of the eracks, as well as gradual motion of the iee off shore. The thaw also materially assisted this latter aetion, and rendered me anxious to reeover our stores, still buried benenth the snow, affording at the same time an important warning, not to be lost sight of at a future season. Had any sudden break-11p of the iee oceurred and earried the ship out, most assuredly a very considerable portion of the standing fittings of the ship would have been left behind, buried beneath the snow, and, as it so liappened, without any soothsayer to divine in what spot. Every effort was therefore direeted to the embarkation of the Observatory, boats, spars, ete. with the utmost despateh; and so tedious did this duty prove, that up to the latest moment it was barely eompleted.

'The next object was the release of the ressels from the iee, still adliering to the bends and bottom, to about seren or eight feet beneath the probable line of floatation. In order to effeet this withont injury to the ship', 
the space between the 'Assistance' and 'Pionecr' was commenced on by saws and blasting; but this proving tedious, owing to very heavy ice, ranging between seven and fourtecn feet, about the lst of July we tested the thiekness of the outer ice to the nearest water, which we fomnd to range from seven feet at our bows to two feet at six hundred yards seaward, where the water was fast increasing.

Brewing from csscnce of malt and hops had becn practised as early as the 6th of August last scason, but the gencral adoption of our "home-brewed" did not fairly commence until the end of Oetober; with what suecess I shall lenve my rcaders to judge from the following report of the officer who superintended. It was much estcemed, and at times mixed to dilute the cxeclleut beer supplied by Messis. Allsopp.

$$
\begin{gathered}
\text { Her Majesty's Ship 'Assistance,' Trellington Channel, } \\
\text { Octolser 31, } 1853 .
\end{gathered}
$$

SIR,

1. In complianee with your direetions, I have the honour to report upon the beer brewed from the essenee of malt and of hops on board this ship during the winter 1852-1853, as follows, viz.:-

2. An experiment was made on the 6th of August, 15.52, to brew with the proportions preseribed by the makers (Hudson and Co.). Eighty pounds of malt and three pounds of hops were mixed with boiling water, and then started into a fifty-six gallon eask (filling it), plaeed by the side of the grilley-fire: when the temperature had fallen to $90^{\circ}$ there was added half a pound of yeast, in a state of fermentation, made by nixing dricd yeast, sugar, and flour, in lot water; but although signs of fermentation were oeeasionally apparent at the bunghole during the day, yet, from the low temperature that prevailed at night (eonsequent upon the absence of the galley-fire), it could not be got to work satisfaetorily. The beer produced, although palatable and drumk by the ship's company, was so weak, from the inadrquacy of the 
quantity of ingredients nsed, and so flat, in consequence of the inability to raise sufficient fermentation, that it was scarcely equal to the smallest table beer.

3. On the 23rd of October, 1852, the ship being fixed in winter quarters, and the Sylvestcr warming apparatus at work, maintaining a constant equal temperature, brewing operations were commenced, with the view of keeping up a periodical supply for the ship's company.

4. The proportions nsed were,--essence of malt, $120 \mathrm{lbs}$, and of hops 4 lbs., to fifty-four gallous of water: these were boiled together for two hours in the ship's coppers, and then pnt into a fifty-six gallon cask, which was placed (for the purpose of obtaining the highest temperature in the ship, steady at about $70^{\circ}$ ) by the side of the fumnel of the Sylvester warming apparatus. In about eighteen homrs after, the temperature of the mixture had fallen to $90^{\circ}$, when yeast was added, and generally in a few minutes produced rigorous fermentation, which was maintained for scren or cight days, the froth bcing thrown of at the bung-hole and received from a leather spout, nailed on the side of the cask, into a tub placed on the deck, from which the cask was kept filled as it bccame necessary, for the first two days almost every hour, and afterwards at longer intervals, as fermentation slackened. As soon as it had ceased to work, the cask was bunged np and removed, to scttle and fine for a fortnight; it was then broached for issue.

5. The beer thus produced was highly prized, and I think I may venture to state that, both for strength and flavour, it was all that could be desired.

6. From this time (October 23rd) until the end of the following April, a constant supply of this beer was maintained, at the rate of one pint for each person twicc, and sometimcs three times, a week, besides other occasional extra issues; for which purpose it was necessary to appropriate thrce fifty-six gallon casks, - one to issue from, the next to settle and fine, and the third in a state of fermentation.

7. The total quantities of the essences consumed during this time were - of malt, $1620 \mathrm{lbs}$; hops, $44 \mathrm{lbs}$; and the beer produced was 702 gallons.

8. Although the beer thus nccessarily issned a fortnight after being brewed was of good quality, yet I wonld beg leave to remark, that had it been practicable to have allowed it to stand for a longer period (as in the case of beer brewed in England), there is good reason to suppose that it would have become searcely inferior to English porter of the first quality. 
9. There now remain tor brewing (to be commenced, in pursuance of your directions, as soon as the hold is cleared), essence of malt, 780 lbs.; hops, 40 lbs.

I lave the honour to be, $\mathrm{Sir}$,

Your most obedient, humble servant,

JAMES LEWIS,

Clerk in charge.

Captaix Sin Edward Belcher, Kt., C.B.,

Her Majesty's Ship 'Assistance,' and Commanding

Arctic Searching Squadron.

Mustard and eress were also raised, under the superintendenee of the sane officer, whose Report also follows. The supply was deemed, for our eondition, adequate; but I am not prepared to state that it would have proved morc than suffieient for the invalids, if we had. been visited by any eases of actual scorbutus; but even as a salad, of which the Freneh sliced potatoes and dried eabbage also furnished exeellent substitutes, it was a most grateful cliange to the eye, jaundiced a little by want of the sun's rays. It is a eurious fact however, that in my eabin, daily exposed to the light of eandles, a decided green tint prevailed; this was grown either on white cotton, wool, or blue flammel, the latter eovered from light. The wild sorrel might be found as a rare plant about us, but, exeepting to botanical colleetors, we did not derive any benefit from its presence, nor indeed from anything belonging to the vegetable kingdom.

$$
\begin{gathered}
\text { Her Majesty's Ship 'Assistance,' N'ellington Channel, } \\
\text { October } 31,1853 .
\end{gathered}
$$

SIR,

1. In compliance with your directions, to report upon the growth of mustard and cress on board this ship during the last winter, I have 
the honour to state, that on the 19th of January, nine boxes having been prepared, of about two feet in length, one in breadth, and four inches in depth, two inches of soil were laid in them, which was obtained from the roots of mosses found upon the land of Northumberland Sound; mustard and cress seed sown over the surfaces, and covered with a light sprinkling of fine mould. The boxes were placed in the main lrold, in the vicinity of the Sylvester warning apparatus, where the temperature ranged from $60^{\circ}$ to $70^{\circ}$, and the soil kept moist by water warmed to a temperature of $80^{\circ}$, and delivered through a rose fixed with a spout upon the side of a preserver meat tin : it required watering about four times a day.

2. On the 3 lst of January (thirteen days after sowing) the first erop was obtained and issued generally to the erew, affording abont one ounce to each person; the soil was then cleaned and invigorated by the addition of a little fresh mould, and nore seed sown.

3. The erops generally beeame fit for cutting in ahout a fortnight, depending upon the temperature that could be preserved, and on an average yielded between fom and five pounds, and, although vellow from the absenee of light, and less erisp and palatable than when grown under favourable circumstances, was generally greatly esteemed; and, in the absence of fresh vegetables, mueh sought after by the ship's company. Crops were thus obtained up to the end of April, the seed consumed being-mustard, 3 lbs.; cress, 3 lbs.; and the quantity produced, about $30 \mathrm{lbs}$.

4. On the ath of June, a box having been prepared of abont six feet in length, two in breadth, and one in depth, soil was made by mixing together a sandy mould, brought from Greenhithe, with that obtained on the land at the winter quarters, and plaeed over a layer of straw and eoal ash in the box to the depth of fomr inehes, when some early lork eabbage-seed was sown orer one-half and spinaeh-sced over the other, and lightly eovered with mould: large panes of glass were put over the top, and the box plaeed on the side of the hill of Mount Beaufort, about thirty feet above high-water mark. An embankment was raised around the box to protect it from eold winds, and every attention paid to obtain a satisfaetory result, the soil being kept moist by water raised to about $60^{\circ}$.

5. On the 27th of Jnne (eight days after sowing) the plants began to show themselves, and from this time to the ship's leaving Northumberland Somnd, on the 15 th of July, marle rapid progress, their tops reaching up to the under suffaee of the glass; they were then pulled 
up, and filled a large dish: land it been practicable to have kept them, under such farourable cureumstances, for three wceks longer, I think ther would have repaid the attention bestowed upon them.

6. Turnip radishes were also tned in a small box, covered with glass, but, from the length of time they took to come up, the result could not be considered satisfactory: the short duration of suitable weather would, under the most farourable cireumstances, render it impracticable for the root to acquire a size fit for use; but occasionally, in warm seasons, the tops might be raised to a sufficient size to be valuable as a regetable.

7. The boxes used in the winter for the growth of mustard and cress were now employed more successfully; the same description of soil was used, mustard and cress seed sown, and the boxes placed, some under the glass covering of the main hatchway, the skylight of the gum-room, the glass binnacle covers, and others under panes of glass; and by being earefilly tended, and watered with water slightly warm, plentiful crops of mustard and cress, in its natural colour and equal to any raised in Eugland, were procmed and issued to the travelling parties after their return from the spring search. The total quantity thus grown was about $25 \mathrm{lbs}$.

8. The seed supplied to the ship was-mustard, $20 \mathrm{lbs}$; eress, 28 lbs.; and 13 lbs. of each still remain.

I have the honour to be, Sir,

Tour most obedient, hmmble servant, JAMES LEWIS, Clerk in charge.

Captain Sir Edward Belcher, Kt., C.B., Her Majesty's Ship 'Assistance,' and Commandiny Arctic Searching Squadron.

On the 6th of July I began to fecl uneasy at the state of the outcr ice; and, fearful that our return parties might be too weak to handle their boats in the rough iee, I despatched Mr. Loncy with a cutter and eight mon, with instructions to touch at Cape Sir John Franklin, Barrow Island, and Cape Lady Franklin, on the southern shore, 
at whieh latter plaee he was to await the arrival of Commander Riehards.

Our eutting operations proved heavy and very tedious. 'The snow bank between the 'Assistance' and the 'Pioneer' having formed into solid tough iee, eompelled us to remove it pieeemeal. This afforded praetiee to the men in the most effeetual modes of removing iee: however, it soon became apparent that the off-shore pressure elosed the cuts as they were made, and that our efforts nust eommence de noio from the outer verge at the water, where we had now suffieient space to float off our euttings.

We had yet it diffieult game to play; as wc were threatened with infinite labour, should the ice move after our eanal was eomplete. My mind had been made up to start on the 14th of July, and every effort was put forth to effeet this object. On the 11th we had completed the first six hundred feet by sixty wide in twelve hours, meals ineluded : the iee had been removed to sea, and doek-gates plaeed to secure it from elosing.

On the 12th, before noon, the entter was diseovered under sail, and the iee-boat of the 'Pioneer,' with the banner of Commander Riehards flying, in tow. We advaneed to the mouth of the eanal, and, opening the gates, admitted them. At three I had the pleasure of taking Commander Richards by the hand, and congratulating him on his safe return, after an absenee of ninety-five days. As we had much to talk of, I sent him to his hot bath, reserving further eommuniention until dinner.

At eight this evening the 'Assistanee' was onee more atloat, her eourse unimpeded, but we had yet to extri- 
eate the 'Pioncer.' Commander Richards was the bearer of complete reports, as far as time would permit, from the western division; the originals were to be forwarded to Beechey Island, and included just the contents of Commander Riehards's letter up to arrival there.

June 8.- This letter of Captain Kellett informs me "that Mr. De Bray, auxiliary to Commander M'Clintock, arrived on the 1sth, having left him, with seventy days' provision, on the and of May, in $76^{\circ} \mathrm{S}^{\prime} \mathrm{N}$., longitude $116^{\circ} 45^{\prime} \mathrm{WV}$. 'To the northward, all the way to Cape Fisher, he could see land, apparently islands, forty miles off : these lie will search on his journey home. Unfortunately, Mr. De Bray lost a man (Jolm Coombs, stoker'); he died from disease of the heart. Commander M'Clintock speaks in high terms of Mr. De Bray; he says he could not have had a better second.

"Mr. Nares, auxiliary to Lientenant Mecham, arrived on the 1st of June; he had a disabled Marine with him: he left Licutenant Mecham on the 3rd of May ; latitude $75^{\circ} 35^{\prime} \mathrm{N}$., longitude $115^{\circ} \mathrm{WT}^{\top}$; having crossed from Melville Island to Prince Patrick's group or land, whatever it may be. 'This name I have given to it, as it was landed on and taken possession of on his Royal Highness's birthday. All these parties will be back by the ith of July.

"Commander Richards's coming here has been most fortunate; lie will take direct to you all information relative to this part of the Expedition, and will also finish the Byam Martin Channel, the search of which I hare heen unable to undcrtake, for want of means. My intended morements are as follows:-1st. Should 'Inves- 
tigator's' crew be found unfit to contend with another winter, I shall proceed with both ships to Beeehey Island. Should I find no contrary orders from you there, I shall despatelı 'Nortlı Star' and 'Intrepid' to England, taking 'North Star's' place myself. and. Should they be found able to contend with another winter on the increased allowanee of provisions, I shall despatch 'Intrepid,' the moment water makes, with that portion of 'Investigator's' erew now here, and reduce my own to thirty men and eight offieers, with direetions to proeecd to England, depositing all the eoal and provisions she can spare at Beeehey Island, if it ean be done without risking another winter within the Aretic eirele, remaining here myself for the result of Commander M'Clure's attempt to eross the strait in his ship, and finally to remain next winter in this neighbourhood, if he fails in getting across."

The remaining parts of his letter, alluding to operations after becoming extricated, must wait for that consummation. Dr. Domville, whom he had despatehed to survey the remaining erew on board the 'Investigator,' had not returned when Commander Riehards left; but he seemed to think that she would be abondoned, which it is to be hoped has long ere this been done. These mousetraps are not easy of eseape! In his private letter he adds, "Should I be obliged to stay, I shall send a party next year to the soutlı point of Baring Island to look for Collinson, and one to Point Coekburn to meet yours or "North Star's." Commander Riehards gives a checring deseription of their luxurious feeding, having been regaled with every known Arctic delicaey but sal- 
mon, and that they pronised, if lie waited until it was caught. I'le following list of ganc killed cxhibits at once the difference of our positions.

'Resolute's' List of GaMe KILLED bETWEEN 3RD OF September, 1852, AND 6TH of June, 1853.

\begin{tabular}{|c|c|c|c|c|}
\hline Inimals. & Killed. & $\begin{array}{l}\text { Average } \\
\text { weight. }\end{array}$ & $\begin{array}{l}\text { Estimated } \\
\text { 11. seen. }\end{array}$ & Remarks. \\
\hline $\begin{array}{l}\text { Musk-oxen. } \\
\text { Deer . . } \\
\text { Hares . · } \\
\text { Foxes . · } \\
\text { Wolves . . } \\
\text { Bears . . } \\
\text { Ptarmigan . } \\
\text { Leumings. } \\
\text { Geese (lately) }\end{array}$ & $\begin{array}{r}39 \\
10 \\
48 \\
46 \\
2 \\
1 \\
81 \\
5 \\
3\end{array}$ & $\begin{array}{l}300 \text { lbs. } \\
160 \\
11\end{array}$ & $\begin{array}{l}500 \\
250 \\
100\end{array}$ & $\begin{array}{l}\text { In all probability the } \\
\text { same animals were seen } \\
\text { by different parties. } \\
\text { Musk-oxen were seen } \\
\text { near this position on } \\
\text { the } 6 \text { th of Deeember, } \\
1825 \text {. Two ptarmigan } \\
\text { were shot on Dealy Is- } \\
\text { land the first week in } \\
\text { Jantary, ls53. May } \\
\text { 18th, eanght a calf, size } \\
\text { of a sinall lamb; died } \\
\text { four days atter eapture. }\end{array}$ \\
\hline
\end{tabular}

We owe a dcep debt of gratitude for all the mereics vouchsafed nnto us. In all thesc travels, dangers, and difficulties, not one easualty has occurred, and health has prevailed. The cuttcr sent for relicf arrived at the very liloment required, and, as if cvery preparation had becn anticipated, the passage nearly to the slip's bow was open. As Kellett and Riclards both observe, "If you had madc your suggestions, orders, to be cxecuted, and drawn them out yourself on a fair shcet of paper, they could not have bcen inore complctely realized." The rendezvous, the discoverced lands, south-west and north-east, have, it is true, all terminated like dreams realized or matters in course; they have caused no ex- 
eitement, no surprise,---they were almost outlined in August and September last, even before quitting England! The last specch at the gum-room table, on the evening before separation from our eonsorts at Becehey Island, was the injumetion to the 'Resolute's,' " to observe the Rendezvous." Most gratefully and joyfully did I find ny old shipmate beside me at dimner, relating his adventures; but his appetite was gone: after his musk-ox and venison fecding, he could not relish even a fair (pickled) Hogarth steak! So much for depraved taste: I know he does not admire walrus. But the main topie was the wonderful and peculiar discovery of the 'Investigator's' position on the return of Lieutenant Meeham. Will the eavillers at the expense of this Expedition now deem it absurd? May not Collinson yet be fortunate cnough to overtake his seeond, and reach England quite as soon? But many a weary mile is yet to be travelled ere we all reassemblc at Beeeley Island, and there only perhaps to form fresh plans for the extrieation of some unfortunate members of our own Expedition!

Richards was truly surprised to find our exit from this position no longer doubtful; for hardly had the eloth been removed, when it was reported that "the canal was open and ship afloat," a serviee exeented in trrenty-six working hours by sixty-four men.

On the summit, and within the eairn on Mount Beaufort, four hundred rations were deposited, duly secured in iron-bound easks. 'The staff surmounting is well marked with a timned light flour-barrel at its summit; and several bands of lead nailed on spirally, bearing the requisite instruetions cut with metal type-punehes, put all 
meertainty at an end. Those would inform the visitor "that in the butt-end of the spar, elosed by a well-prepared plug, full information would be found." The roll on which they were inseribed was protected by tinfoil and glue, again by bladder, and finally by tinfoil: it may last for ages. The easks and other pieces of wood strewed abont them wonld afford substantial fuel for heat, as well as eooking: they were not reduced.

Richards found at the rendezvous, that Lientenant Osborn had taken the boat and gone to the sonth-east, to examine the eoast between Cape Lady Franklin and Cape Marshall, and Goodsir's furthest: as his date and provision would expire on the 15th, we shonld not be long in doubt. My orders for his guidanee, sent by Mr. Loney, were left at the rendezvons. Richards and Loney then proceeded to examine Barrow Island, but without diseovering the remotest trace of our missing eountrymen. A cairn was construeted, and notiee left; they then repaired to the ship. The sooner therefore we show ourselves on the dark-blue wave, the sooner our stray sheep will rejoin. A depôt was prepared for Loney's station, at the southem point of the bay. I visited my main station on Pioneer Island, and obtained a clear view around; took leave, and on the morning of the $14 \mathrm{th}$, eleven months from the date of our quitting Beechey Island, started in the 'Iamilton' to place the depôt on Loney's Point, the southem and well-known station of this somnd, surmonnting it by a large blue and yellow flag, horizontally divided. I was yet rloubtful as to the moment of starting, and had prepared provision for "sleeping out," ete. Having already ordered 'Pioneer' to have her stean up, 
the signal to start was made, and onee more $I$ had the satisfaction of sceing the vessels in motion on their proper element. They were brought to a temporary block between me and Spit Island. This was eventually orercome, and I rejoined at eleven P.M., just hefore she entered another lane leading towards Cape Sir John Franklin, where Commander Richards and myself landed about one A.M., and visited the station on Hount Perey. All the southern land was well defined, but, aided by a powerful telescope, I was unable to diseover the beacon on Cape Lady Franklin, or any trace of our boat. I remarked that the latter might possibly lave taken the western side of Spit Island, and thus be hidden. 'The sea was still open up to the point, shutting out Cape Beeher. The therefore rejoined and moved on: Lientenant Osborn, having my instruetions, would scek the ressels in that direction: further instruetions and provisions awaited him at Loney's station.

July 15.-At midnight Lientenant Osborn was scen at our floe-edge, and a party sent to aid him in the 'Hamilton.' 'The mode of direetion to both parties was by plaeing two ship's flags on the proposed line of junetion; ench party keeping these in line, - although not in sight from each other, by reason of high packed ice,must naturally mect.

Shortly before midnight Licutenant Osborn rejoined. As I antieipated, he landed at Spit Island, and was asleep' when I was seeking lim by teleseope from Mount Perey : finding the bay vaeant, he moved forward without ealling at the depôt on Loney's Point, and fortunately overtook the ship. His seareh of the southern eoast of 


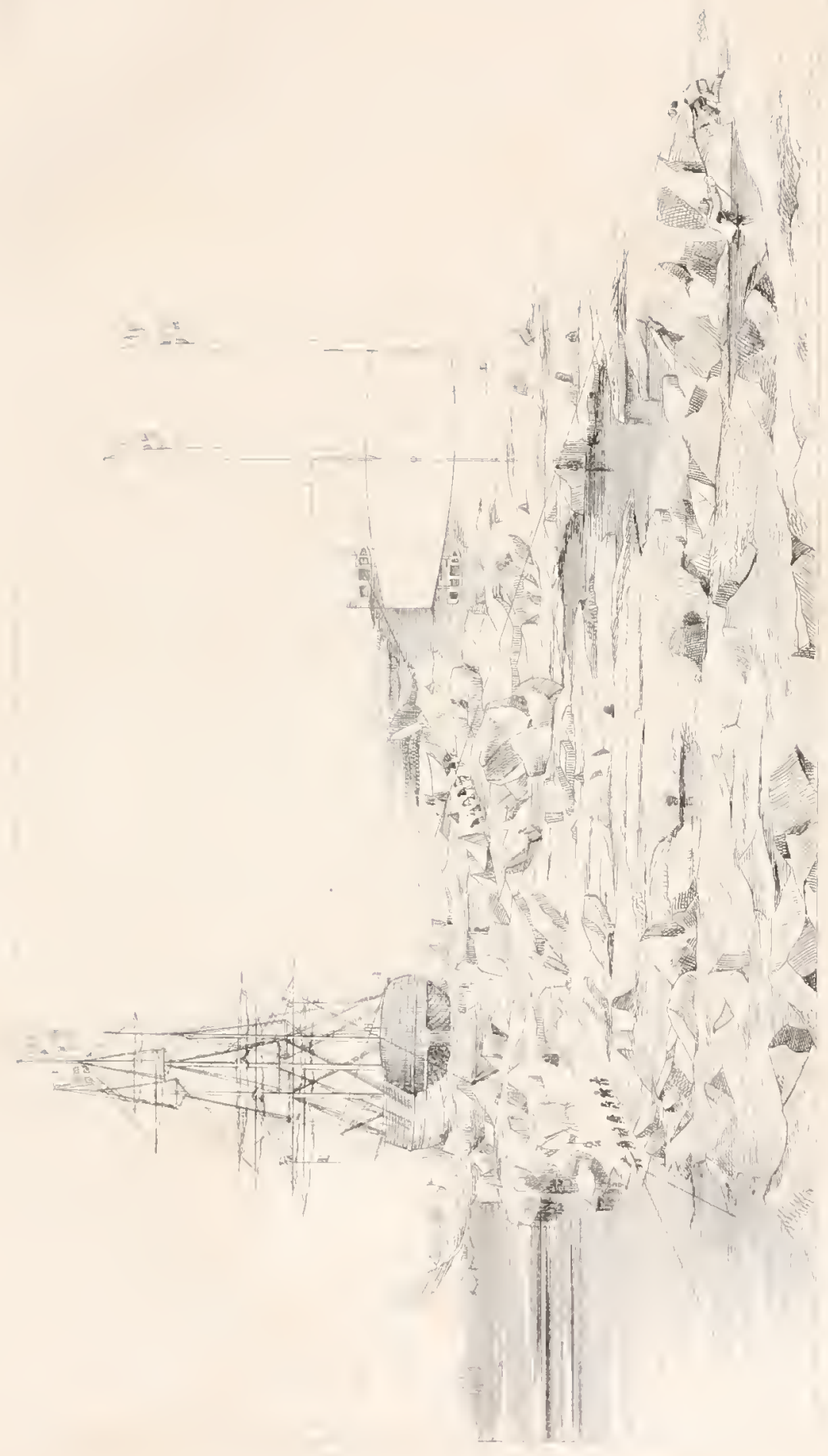



Queen's Channel had been unsuceessful ; and as all his news had been anticipated by Commander Richards, and both were weary (I had not slept for I will not say how many hours, and the ship was fast to the floe), we parted to rest.

Here we are all, thank God, safe, and in good health! Our advanee too, even thus far, is matter to be thankful for, and in these regions almost another achievement.

The tedium of detention I shall pass over; we gained by it a longer sight of Barrow Bay and Johnny Barrow Mount than was interesting, and on the 17th we fortumately got inside the movable pack, and made fast to the solid land floe, with one anchor down, at cight P. n. The iee here was very heavy, and aground in seven fathoms, consisting of massive piled hummocks up to the shore. To be caught hore undocked would be dangerous: still, there was barely depth to do this with safety, and a heavy stony gravel lay beneath. Ascending the high shoulder of this mountain,-which I named Acland, after that esteemed baronet, Sir Thomas Dyke Acland,--I found that it coincided exaetly with an object which I had taken from Mount Perey, with the idea of making it a station, and from which it conld be scen through a gap in the island intervening. It commands the north entranee to Sir Robert Inglis Bay, Capes Beeher and Majendie, Dundas Island, and all round to Barrow Istand and Long Island extreme. A very eonspienous cairn was here ereeted out of litrge masses of magnesian limestone, not likely to be affected by weather or time. Our dock was eut into four fathoms. From this height I discovered, about fire miles off shore, what I suspeeted was an island, 
in August last, almost a spit in the fairway, and not far from it an isolated mass of ice, evidently aground; two dangers which we have now time to determine, and as the ice at prescnt does not appear to offer any chance of escape, the cxamination may afford amusement.

From the view which this mount afforded, I could trace open water from Cape Becher to a ncck south-east from us, about scven miles, affording a broad triangular space of opcn water, within three miles cast of our position. On the west it was met by another werge of water about two miles beyond our island, from which, in a curve eastcrly, it formed up to our position at the floeedge. All this ice appeared firm, and did not indicate any symptom of laving moved this season near the small island. It was grounded, and appeared to have formed on it, not pressed up by violence: this little island, for the present, was termed Assistance Spit.

All the possible projections within and without the Queen's Cliannel have now been so minutely visited and searchcd, that I feel fully satisfied that Sir John Franklin's ships left no traces of their visit, if thcy cver passed up Wellington Channel, which we consider vcry problematical. I spcak not of small cairns, becausc he never, with Fitzjames as his aid, would do anything by halves. But $\pi^{\circ}$ have but too often been disappointed even by a moderate-sized stone, to pass over anything constructed of that matcrial. It is true, cairus or piles will tumble; but they still leave enough to excite attention, although some of Penny's travellers have not so placed them that they are easily found : and the erection of two so near as Cape Majendic and Cape Becher, and placing them on 
the cliart so far asunder, nearly deranged my communications, Cape Majendie haviug been mistaken for Cape Becher, and there our depôt was placed. At all positions visited by this division the cairns have been rebuilt; should they tumble, they still will exhibit remarkable piles. Other observations on this channel will follow hercafter, relating to its uncertain navigation, which will probably dispose of the second question,- that of vessels being drifted up, subject to pressure.

Mount Acland is composed of rubbly magnesian limestonc, without one trace of vegetation from summit to base! If I may use the expression, it is awful to behold these mountains of mimute stones, difficult, from their loose rubbly nature, to walk upon, and piled up to the lighliest limits of these ranges. It is really a great relicf to find rocks; and as in the present instance it happened to occur upon an inclined ledge, which furnished sufficient material for our beacon, a very conspicuous one was erected. I cannot furnish the honourable baronet with any particulars which may induce him or any other friend to pay it a visit.

Commander Richards was sent to examine Assistance Spit, as well the ice aground near it, and to try a few heavy charges of $20 \mathrm{lbs}$. on the main floe, having fiequently cxperienced, in Melville Bay, that evell our small blasts at times did great mischief amongst the whaling fleet, causing even distant docks to split unexpectedly; the use of our porvder was not unfrequently condemmed. Having erceted a beacon on the small island, and completed his other work, he examined the grounded ice, where he found only three fathoms, with seventeen be- 
tween it and the island; possibly it has less beneath the iee.

On the 25th the ice opened between us and the spit island: steam was ealled in aid, and about five P.M. we were again advaneing to the eastward, but the tide evidently strong against us. At 11.30 we arrived at the end of the lead; made fast until eight next molning, when we again got free, and, hy shaving Cape Beeher in eleven futhoms, passed that important point. Mr. Herbert (Mate) had been despatelied to the point to seek for letters, and to bring away those left by Mr. Cheyne in May last, if they should still be found. Our attention was, of eourse, intently fixed on the pile; and nearly at the moment that we diseovered, by the aid of our glasses, that the kegs eontaining the letter's had not been taken, "two boats were reported eoming from Dundas Island." One was eertain, and Commander Pullen shortly after" stood on our quarterdeek, little less astonished than ourselves at sueh a meeting; he had eome for these letters! I was right glad to see him, for I had mueh to inquire about and mueh to learn. Definitive instruetions for himself, for 'Intrepid,' and the whole Squadron, had to be made out, and but short time in whieh it eould be eompleted. I thought of detaining, and earrying hin baek in the ship. Fortunately for all coneerned, he had left his men and depôt at Cape Phillips, and must return, thus seeuring the opportunity of forwarding our lumied and mopened former despatehes. We were detained just beyond Cape Majendie: there we hung on by the floe until morning, when I took leave of him, instrueting him to plaee a eylinder eontaining a record of 
our mecting, ete., on Cape Majendie, with which he was supplied.

Being now in full possession of all our intelligence, and knowing the interest which must be felt at home, about the great object of this Expedition, as well as of our present proceedings, I directed him "to be prepared to leave Beechey Island on the 1st of September, and proceed to England, taking on board the erew of the 'Investigator,' shonld they arrive by the 'Intrepid,' and to leave the latter vesscl as depôt at Bcechey Island." I fully expected, at this moment, to reach Becehey Island, in this ship, before him, and long before that period direct in persoll all the necessary arrangements.

From this date until the $17 \mathrm{th}$ of August we continued to move from spot to spot, sceking easting: opinions very conflicting and unpleasant in their obtrusiveness were hazarded,-_" too many cooks" never were more apparent. The south shore was the favourite; lowever, thank God, I took the nortli, and moved in that direetion with all speed; not from the littleness of laving my own way, but because no opening, after reducing opinions to record, was truly scen to the south-east; that the three Ice Quarter-masters, closely questioned daily, saw no prospect by that direction; that Penny's remarks, which Sir Francis Beaufort had obtained from him at my request, distinctly opposed any navigation on that side, and he lad travelled there; and finally, that at this date last year we had navigated the north side, and found it elear, when I, from the heights above Cape IIogarth, was well satisfied that the ice blocked the space between Hamilton and Dundas Islands, and appcared morcover to press 
southerly. All the northern channcl was then free; but to silence future cavil, the ship was pushed to the soutlcrn navigable extreme. We had expericnce against presumption. As the spring-tides would probably bring danger, I deemed it imprudent to risk further ships or lives, and therefore determined to take the north lead. We shifted, and were scarcely wcll sccured, when the ice took a westerly set; our floe was firm, therefore we went bodily, shcltcred by a natural cove or dock, and flanked by very thick icc.

The spring-tides occurred on the 18th, and I relicd much on this cvent for some dccided movc; unfortunatcly, it was in a wrong direction, or, if my own suspicions are correct, I lost my chance by quitting this shore at all! Our boat landed oncc in open watcr, well to thc eastward of where we now wcre; a gale cnsucd! Wo continued to drive, apparently for the strait betwcen Capc Bcchcr and Dundas Island. The barometer fell lower than before noticcd, suddcnly from $29 \cdot 64^{\circ}$ to $29 \cdot 34^{\circ}$. We wcre now drifting rapidly to the westward, our deptl of watcr decreasing from thirty-seven to cleven fathoms; and, as the snow-storm intermitted, discovering to us the near ncighbourhood of Cape Majendic under our lee! "When things arc at their worst they mend." The great floe continuing to turn in azimuth, like a wheel, to the westward, fortunately tended to throw us into the channel, between Cape Majendie and Dundas Island; not certainly pleasant, but ncvertheless affording hope of safety. At this crisis, providentially, the ice to leeward becamc blocked, or possibly was in part resisted by an opposing current. We ceased to drift, but had 
shoalcd our water suddculy to eight fathous, not far from a low point spitting westerly from a very tcmpting bay, in which I had for some time fancicd that shelter could be obtained, provided the depth afforded safe riding. Our greatest danger however still thrcatened : umless the iee to windward was arrested in its motion, it would inevitably elush us in a few moments! and this was feared. One of the Ice Quarter-mastcrs observed: "If the weather floe parts, Sir, it will walk over her!" Not a very pleasant prospect! The customary preparations for deserting the ship were already cared for, and wc waited, in great anxicty, the result of the next halfhour. If both vessels were ammililated, life, I think, night possibly liave been safe; but we had two sick men, eripples, and for these my interest was principally cugaged. The weather icc was arrested, as afterwards asccrtained (under frightful pressure, highcr than our lowcr mastheads), on Point Preservation; the galc lulled, and I was able to send a boat to sound up to the landfloe inside the point before alluded to. 'T'he report of "cleven fathoms within, and nime close to the point," soon put a new face on affairs; warps werc run out to windward, and, under trysails and jib, the ship soon reached one of the most seeme little ports in these regions. On landing at the spit I found the depth " elose to" sufficient, if eompelled to winter, to admit of the ressels sceuring to the land, having six fathoms at sixty fert from the beach, and spaee for twenty vessels in the then open ereek, whieh carried to its bend, at a later date, ten fathons: to this I gave the name of Port Refuge.

The vicw from the hill now forcibly impressed on my 
mind the advantage of decision : if the Captain is not fit to command, he should not be sclected; the lives of all are in his kccping, - one falsc step, and no one survives to tcll the tale! The grcat evil cntailed on this service, at a period when $n$ great experience entitled the Commander to be decisive, and lie had Ice-masters to help him, was the referring to Council, or, as I now view the case, to rclicve limsclf from the responsibility of any unfortunate event which was liable to be contested by thosc under him. At that period the Expedition was composed of officers of nearly the same rank; the case is now far different, nor do I require any such protection.

The position we had latcly occupied was now closed in with heavy, hummocky, pressed-up ice, - and 110 trace of floe, such as wc left. Probably the ice to which wc were then fast, and having a very wide crack, leading possibly miles casterly, now formed part of the piled-up masses on Dundas or Margaret Islands, or, if it escaped thesc, passed up the Quecn's Cliannel! I felt grateful that the pressure lad not becn tested by the resscls under my command; for therc I do not believe that life would have been saved. Easterly, the coast was lined with larger masses of icc than we had beforc noticed, grounding in three fathoms and a half, and pressed so heavily in upon the shoal line that it interfered much with my purpose of making my escape betwcen them and the land. Viewing the coast westcrly up to Capc Majendic, we had to be thankful that we were not cast upon that umpromising iron-bound coast. Such then being our own escapc, my thoughts naturally reverted to the casc of the missing shipss; any similar casualty 
might sweep them from the faee of the deep, and leave not a trace bchind! The presenee of a eonsort conld not avail; they are generally, as it were, linked together, particularly when beset in iee, and the same fate to both, ill our ease, would eertainly have resulted.

Here then our present prospeets were at least painfully delayed, and by many were eonsidered to be entirely frustrated for this season. But although opinions were perhaps too openly expressed, I deemed it prudent to be prepared for taking the paek again, asscrting distinetly, "that the ressels should not winter there." In order to keep up the exeitement, I first made the survey of the port, and then started in my gig to determine low far I eould safely take the ship within the grounded hummocks. Day by day led on to freslı advanees, until I gained the lieights about nine miles easterly, elose under whieh Mr. Grove had landed in open water on the 15 th of August! We ean only imagine that an overruling Providenee direets us! One of two events might have oeeurred ; the first was our possible eseape into the eastern open water, at this moment elear up to Point Hogarth; the next our ummistakable demolition, had we been pressed on Cape Preservation! 'The height of the iee piled there, within whieh our boat entered freely at high water, was not under eighty feet on the inner side, where a sloping cébris, eomposed of fincly comminuted partieles of the purest white iee, fell inwards. To seaward it was piled with enormous bloeks of ice, one over the other, in perfeet eonfusion: not ordinary iee, but of the same quality as that grounded in three and a half fathoms along the eoast, varying from twenty to twenty. 
four feet in thickness! A very narrow neck of thin floc, easily to be mastered if we eould reach it, eut off our eommunication with the lanes, constantly opening and closing, but near to Port Refuge closely sealed. The inshore "lead" was not deop enough for the ship, being barred at Cape Simpkinson by a roeky ledge, on which two fathoms only could be attained.

At this Cape we shot eight hares: five the first day, and threc the second. This therefore afforded some little excitement, and the ship's eompany had permission to sluare in the amusement, killing some humdred of kittiwakes and tern, with one hare and eight ptarmigan. These cliffs are frequented by gulls, lummes, dovekies, and other birds, which build their nests in rocky ledges of the beetling eliff, in order to secure their young from the depredations of foxes and other predatory animals, and are generally, when sufficiently stocked, termed "rookerics :" one at Cape Shaekleton, in Melville Bay, and another near Upernavick, are well known to the whalers, as well as Arctic explorers.

By some unaccountable peeuliarity I make up my mind to effect an object, at a moment when no chance of its accomplishment is apparent! Not that I would attempt it against reason. Thic reverse: I rather spare labour, when I can do so conseientiously. I took my last survey of Port Refuge, killed several ducks and a ptarmigan, and overlooked the principal features of Sir Robert Inglis Bay from Mount Croker, situated at what wc had at first deemed the almost out-of-range depth of Port Refnge, but to which access was now open by water within the ire. From this height I diseovered, 
what indeed I had before suspecter from other glimpses nearer to it, that a lake and stream connection existed between this and the eastern sae of Sir Robert Inglis Bay, and that not more than one mile divided the two waters. Westerly, I noticed the ice to be casing off at Cape Majendie, and lanes forming along the eoast towards it. A vacancy is always of importance, and to us of infinite value,-as it would facilitate the opening of similar lanes to the eastward. I felt suddenly confident of release, but all the reports from the hill were unfavourable : indced the Ice Quarter-master, who had most to say, pronouneed the floe sealed for the winter. Further, the bay ice had formed so thick, that it was not possible for a boat to pass to the shore without considerable labour in breaking a channel. However, a night would intervene, bnt the cold was mole intense, and the ice firmer. I asked the Tce Quarter-master, at four A.M., what he thought of it? "No opening, Sir," was the reply. I may be obstinate, but I told the "old man" (Unthank) I intended to cut out; he quietly and very drily whispered to me, "Well, Sir", if you are determined, lose no time." 'l'hose words were cleetric,--took a load off my mind; I was up, out, and moving. Leaving orders " to prepare for sea, and clear the lead to the ontside barrier," I mounted the hill, and therc noticed that outside of our opposing barrier rather an unwieldy and awkward floe was freely washed externally, and that if this could only be mastered, by cutting and blasting, my intention to take the pack, following up the outsides of the grounded ice, might enable me to squeeze by Point Preservation. 'L'he distance from hence to Beechey Island, one hundred 
and twenty miles as the erow flies, was too far to transport erew, invalids, and effeets, if eompelled to abandon next scason. Effort must be made, and I had resolved on it. Lientenant Osborn was direeted to take a party to blast the ontward barrier. Boats were employed in beating and hauling through the bay iee, so as to diseonnect it as mueh as possible, and the ship having been warped up to the barrier floe before noon, the 'Pioneer' followed under stenm. Repeated reports were brought to me, "that the ice elosed as fast as blasted:" this I heeded not. All our available foree was now sent on the iee, and I took the eommand in person; the vessels moreover were now well wedged in, and no ehanee of retreat. Several heavy blasts were applied with great effeet, followed up by the expeditious removal of the outer disrupted iee; and by the aid of steam, both vessels began to move eheerily ahead. "Sauve qui peut" soon beeame the general motto; and eaeh man springing to his proper vessel, shortly after noon they were onee more under eanvas, and moving to the eastward. Let any man read the log of that day, and judge simply from its wording if it was intended to illustrate any sueh feat.

Before entirely taking leave of Port Refuge, I will merely remark, as to its geology, that the same dreary, dirty, grey magnesian limestone, with but few fossils, prevailed; and vegetation, exeepting in the inner valley under Mount Croker, where deer or musk-oxen had rooted up great spots of deep moss, was very rare.

On the summit of Mount Croker, whilst engaged with the theodolite, I notieed a very benutiful white ermine (Thustela erminea) in its summer dress. My aide, Mr. 
Pyn, was despatehed to shoot it; but he failed, although the animal was daring enough to sit up and spit at him within twenty yards. The bifureation of his fine bushy black tail was beautifully displayed, and probably somewhat disconcerted Mr. Pym, spoiling his aim. I believe however that it was wounded, and effeeted its eseape by the ereviees of the roek. Nearly at the same moment a ptarmigan (mistaken for a goose or deer) was noticed: on $m y$ return it was butchered, by getting suddenly on it before I pereeived it; however, in these times we kill for the eook, not for preservation.

Our eolleetion from the sea has been more abundant than I eould have imagined, an aeeount of which will appear with the Natural History. The Euryule or Asterias Medusa was found in great numbers in deep water, and on one oeeasion so bematted a swab, that extrication, witlout destroying the arms, was not possible: one complete speeimen only, to cstablish the speeies, was preserved.

After a detention of a most harassing nature for thirteen days, we were again free, and pressing forward. But before quitting this region let us examine the relative temperatures expericnced by Parry and ourselves. During the entire month of August, 1 $5: 0$, I notiee that he experieneed a minimum temperature of $22^{\circ},-$ colder than we have experieneed at all,- - the lowest, at four A.M. on the 31 st of August, corrected, being 24.5 . As he had quittcd the entranee of Laneaster Sound before the 1st of September, we eamiot follow him; but at Port Bowen, a much more suspieious position, it did not fall below $16^{\circ}$, and that not mutil the 1Sth. I eonsider that as far as the 16th of October of that year I would not have 
deemed myself sealed. His eseape again on the 1st of September into warm water preeludes firther eomparison with the probable temperature in the mouth of Wellington Channel.

September 1.-Our first effort earried us abreast of Cape Simpkinson, where, finding the paek drifting westerly, we made fast to the grounded iee, in eight fathoms, to await the return of tide. But I find that the tides in this northern bight are not to be reekoned on, and in the present ease, fortunately perhaps, they overran their mark to fifteen hours. Foreseeing the reaction, I gave orders, before I retired to rest, "to seleet a eonvenient tug floe, and make fast to the moving pack when the tide elanged easterly," whieh would infallibly advanee us. This ocenrred at 3.30 A.M., when the pressure gradually eased ; and shortly before eight A.M. we were again taken in tow by the 'Pioneer,' keeping elose along the line of grounded hummoeks, and on arriving abreast of the immense mass before alluded to off Cape Preservation, had fifteen fathoms elose alongside, the sea washing its base. 'l'hese huge masses of ice furnish most valuable guards for pilotage, seldom grounding in less than three and a half fathoms, with deep water outside. I had suspected, from notieing the vast eolleetion of pressed-up iee at this point, that they were obstrueted and retained by an outlying ledge of roeks; but the heavy masses then notieed merely adhered until the pressure was relieved, and then by their weight had been swept away. The eustomary law of the immersion of six-seventlss we found not to hold here, nor are the under surfaces level: masses more than six feet out of 
water were gromuded in two fathoms at high water! but these must have had a great admixture of snow. I had almost fancied that my vision of open water up to Point Hogartl was not to be realized, and that my efforts after all might be attended with some drawbaeks. But about noon I canght a glimpse betwcen the masses of ice, and felt that all was secure. This was indeed a triumph: talk not of horse-raees, or any games of eliance! Here was a eonsummation to repay all my harassing labours. Giving the men time for their dimer, the ehcering sound of "Hands makc sail!" brought up many an inquiring faee. But there was no mistake this time: the open dark blue sea was before us! How different were the feelings of forty-eight hours!

What the sensations were of those around, I was unable to discover; but I had the deep satisfaetion of feeling that I had, by the blessing of God, effeeted ny object, and impressed all the well-disposed men under ny eommand with the determination whieh will, I trust, under the blessing of God, enable me to do my duty, and that where I decide, no puny obstacle or difference of opinion shall deter me from the aeeomplishment of any service I may deem it necessary to cxceute. If I had failed, no disgrace or reflection eonld lie. Still the story would run, that I made the attempt,-and thus elose the mouth of the busy chatterer.

The questions now diseussed were not of failure, bnt of the hour of arrival at Beechey Island, and if we should save post by the 'North Star'! Shortly after two the tow-rope was let go, and under evcry possible stiteh of eanvas, the ship was making nearly seven knots. But 
alas! our caleulations were premature. About four P.M. indientions of ice alıead were reported, and we were reduced to the neeessity of seleeting the most comfortable berth whieh offered amongst the patehes of open water, about ten miles to the north-east of Cape Osborn. Unfortunately, the 'Pioneer' shortened sail some miles astern, and before slie reaehed the gap by which we had entered, it lad elosed, and separated her so far as not to be of further assistance until the eommunieation was opened.

During our detention herc we determined our position to be in lat. $75^{\circ} 37^{\prime} \mathrm{N}$., long. $92^{\circ} 22^{\prime} \mathrm{W}$., Cape Osborn

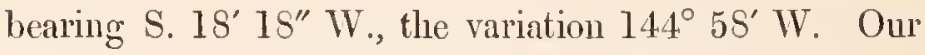
distance from the nearest land was about one and a half mile. A party eonsisting of Dr. Lyall, Mr. Pym, Mate, and Mr. Lewis, Clerk in eliarge, started with a light boat to endeavour to rcaeh the land, and walk on to Cape Osborn, on the summit of whieh we thought we eould diseover a large cairn or tent. They were unsueeessful, owing to the roughness of the ice, and the ineffieieney of their party to drag the boat over the distance which intervened between us and the shore. It was in the sequel most fortunate. 


\section{CHAPTER XIV.}

First symptom of Winter.-Alarming-Discorery.-Suspicions awakened.

- Escape from a Nip.-Recent fragment of a Ship.-Drift-wood.P'arty for Beechey 1sland.-Despatch of Tieutcuant Osborn.- Want of Stean-power.-Unsafe position. - Aid sent to Licutenant Osborn.

-Iuland Lakes.-Fishing.- $\perp$ Spar found.-Trunk of a Tree.Disturbance of the Ice.- Fragments of a Ship.

September 3.-Aт midnight there was not sufficient light to read the deck thermometer withont a eandle, and quite dark in my cabin. We are now to the northward of Eden Point in Baring Bay, and in eighteen fathoms water. A bear was noticed between Cape Osborn and the ship, but he most cautiously avoided any nearer approach, or within any distanee to warrant pursuit. As the 'Pioneer' was completely eut off, our efforts were now incessant, taking advantage of every motion of the ice which enabled us to get into the in-shore water, hoping to seeure to the grounded iec, and thus prevent being swept back.

On the morning of the 4 th I sent Lieutenant Cheyne, with a gig and one wateh, to aid the 'Pioneer,' whose services we very much needed, the open lanes rendering constant warping tedious, and I had the satisfaction of 
seeing that at least she was moving. Our progress, being free from obstruction, was more rapid, aided I imagine by a eurrent along the shore; and by six P.M. we sueceerled in wapping alongside some stupendous masses of iee or fragments of bergs, grounded in eleven fathoms, and raised above water about forty feet. Whilst engnged in warping along these, the look-out in the erow's-nest reported "something like a coal-bag and a uniform eap, lying on one of the detached in-shore floe-piees." Our glasses soon deteeted the blaek objeet to be one of Halkett's India-rubber boats! Mr. Grove, Mate, was immediately despatehed with the light boat, whieh the party hauled over a low neek, and reaehed the objeets. On his return he brought the India-rubber boat (the bellows having been mistaken for the eap), a tin ease containing the Admiralty Aretie Chart, the true-bearing book of 1853 , two tin pannikins, a hank of log-line, bits of lint, a pillbox eontaining ointment, and a pieee of adliesive plaster, -with other proofs of its having been the temporary resting-place of man!

That all the articles in question belonged to our Expedition was elear by the date of the ehart, as well as the true-bearing book for this year, within which was further found a printed prayer belonging to the 'North Star,' as well as one in manuseript, evidently in the handwriting of Commander Pullen : the ehart was also his, having on it his remarks on his late joumeys hitherward. But the Halkett's boat erented a doubt, as the 'North Star' was not supplied with one, and yet it bore the broad arrow ; it might therefore have eome from the 'Resolute' or 'Intrepid.' As soon as the ship was se- 
eured for the night, I returned with Mr. Grove to exanine afresh the spot where these things were found. The boat had evidently at first occupied a place on the floe, where the sun or the heat of the man's body had impressed all its leading marks very perceptibly on the iee. It was painted black, and therefore by the ordinary laws of nature should have been more dceply imbedded, as the lighter-eoloured artieles had sunk in deeply, and become well frozen; but the breeze had blown the boat orer the ledge, and it there lung, attaehed by its frozen lines, as a signal of distress: Nature's own act! No further clue eould be gained. The bay ice was forming so rapidly that Mr. Cheync's party were hauling the gig over the iee; bnt where we were, the boat easily cut through by the veloeity afforded by the oars. On Mr. Cheync's joining, by signal, he was instrueted to search the inner masses of iee, whilst I eontinued to follow up the line of gale of the 18th of August, to whieh date I inmediately assigned this alarming catastrophe. It is almost needless to add, that suspieion of misfortune to Commander Pullen predominated, as I eould not for a moment inagine that le "rould trust any other person with such doemments: I also felt assured that it resulted after his return to his ship. No further traees were at present diseovered.

Here was matter for most serious eonsideration, and involved advance or delay! But it was clear to my mind that if any misfortune oeeurred to a party in this immediate neighbourhood, that traees must be sought for on their retnrn to the 'North Star,' and that the nearest land would soon furnish evidenee of their resting-plaees.

VOL. I. 
For this purpose I despatched Lieutenant Cheyne and Dr. Lyall to examine the coast for traces, cairns, ctc., and to visit, if practicable, the shelf-summit of Cape Osborn, on which I had imagined that I saw a very large cairn,** now transformed in importance to a tent.

September 5.-The 'Pioneer' rejoining at 4.30 A.m., again took ns in tow, but not making sufficient progress to overtake the land party. The boat's crew, on their return, reported having seen the remains of a bivouac of last seasoll, whcre tea-leaves and preserved-mcat tins were distinctly observable. About two P.M. the party returned without finding traces of any late visitors. A loosc, distmibed cache, formed from the stones of an old Esquimaux encampment, was reported by Dr. Lyall.

The ship having gained the bay to the southward of Cape Eden, the 'Pioneer' fouled her fan with our towropc, and was placed hors de combat so long, that we warped, on and had gained a very critical point, when she came up, but too late to carry us through and rather in our way astern, as a very serious nip was on us, and we barely escaped between two such huge masses of ice, one aground in six fathoms, that our fate would very soon have becn determined. The angular tongue of a huge floc-piece-how many feet thick I cammot say-lad taken its hold just under our fore-channels. Our opposite broadside took against the grounded hummock, half-way up our rigging. Fortunately a twentypound blast broke the nip at the critical moment, and

* This supposed cairn turned out to be a very remarkable pyramid on a jutting buttress of the cliff, showing out on particular points of view, but beyond the actual Cape. 
she eased astern. Let no one sneer at blasting ice; this alone saved the 'Assistance." We were very glad now to take refuge under the lee of our big enemy, whcre most beantiful doeks were already prepared, but too insidious for any dependence. The powcr which placed them there eould as easily move them, and the collision would destroy us in a moment, cven in calm, and witllout one instant's warning! We had therefore to seleet our ground, and cut in so as to be frozen steadily, until we eould make another move. It was very tantalizing, as well as distressing. More power, more aetivity, would probably have plaeed us beyond the barrier which now elosed us in as if for crer !

Being now fast and fixed until it pleased Nature to release us, I despatehed $\mathrm{Mr}$. Grove to take thc shortest course to Cape Osborn, and examine the eairin; but I had been much deeeived by the distance, as wcll as by the nature, of the intervening ground, as well as its aeessibility. Ile returned, after an absenee of ten hours, unsuecessful, but lie determined that the objeet was a natural heap, not a cairn; no traces of travellers were noticed along lis route. 'The party reached the ship about fivc A.M. on the 6th, much fatigued, and the fog whieh prevailed tended much to increasc their diffienlties. Mr. Grove found threc piees of wood, two very old and weather-morn, but one recent, of teak, painted blaek on one side and having a new nail through its end. It had reently been cut by a fine saw, apparently for firewood ; the nail had not the Government mark.**

* This proved to be part of the 'Breadalbane,' wreeked fifty-five miles to the southward. 
It is a enrious question, bnt, trivial as it may appear, no less my duty to reeord. How does it lappen, throughout this northern line of eonncetion, and ont towards Jones's Sound, that nearly all the trilly drift-mood found by our parties might have belonged to the same tree?never reeent, and inpressed with Nature's own seal of one partieular epoeh. Let the fragments preserved answer for themselves. When are we to expeet a new and different supply? This pieee of teak will donbtless be traced, in a few days, to some definite eause of aetion; it simply assures me that the Wellington Channel is, or has been, open : at present I suspeet it to belong to the 'Mary' yaeht.

September 7.-The morning, ushered in by thiek fog, has terminated in a gloony, wintry day; the barometer is slowly falling, and with it all our ligh hopes; the breeze also is freshening from south, and the iee betraying symptoms of uneasiness. We have no bed of roses here: independent of the safety of the ressels and erews to dwell upon, mueh matter for severe thought remains. The present wind may be onr seenrity; but slould it haul westerly, even these barricrs to which we are fast would afford no protection,--perhaps destroy us; our trust only is from above; our motto, "T'rust in God, and do your duty," renders every disaster comparatively light.

Fully inpressed with the belief that a party in scarch of $11 \mathrm{~s}$ has attempted this eastern side of the chammel, and may possibly have simply lost the artieles diseovered, I direeted a depôt of eighty rations to be formed on the near terrace of this bay, surmomited by a yellow flag, 
that colour being best scen either on a dark or white ground; indeed expcrience has tiught me, that as a general beacon flag, the yellow-blue lorizontal can be distinguishad beyond all others. At noon the tempcrature was $30^{\circ}$, but with every indication of approaching winter ; and as I remained unensy about ou position, the Master was sent to mark out the shoal-line at which we should take the ground, if driven in, so as to enable us to make suitable preparation. This was effected by boring holes and sounding, leaving staves at thirce fathoms. It ap)pcars that we lad about il humdred yards to drive bcfore taking the ground.

On the 7th preparations werc made for sending a party in the "Hamilton' to Becchey Island, in order to ascertain the state of things there. As to saving the chance of letters by the 'North Star,' nuy orders, if open water cxisted, had taken effect on the 2nd, or some other' channel liad offered. I could only forward ny report of morcments up to the latest date, for sufe deposit, until some chance offered; for this service Commander Richards voluntcered as a matter of right, but I could not sparc his valuable aid at-such a critical moment, and Lieutenant Osborn was therefore allotted to this duty. My own well-tricd crew were selceted, substituting the ice-quartcrmaster of the 'Pionecr' for' my coxswain, whom I could not sparc; and my light dog-sledge, constructed to carry une and forty pounds' weight of instruments, was added, to carry light loads at difficult or tender passes; five days only of provision were allotted, and every useless weight left behind.

On the 9 th, dirty, snowy weather; barometer, $29 \cdot 45^{\circ}$; 
temperatures ranging between $7 \cdot 5^{\circ}$ and $15^{\circ}$, and the ice nipping. Made an attempt to eut towards the nearest pool of water, bnt failed; the iee was found to be fifteen to twenty feet in thiekness, bay ice six inehes, the water clearly making round Cape Osborn and to the northward. Tantalizing indeed to be mewed up; but patienee! we were nearly as bad in Port Refuge, and yet eseaped. In this position we are sheltered; but ovcrliead the gale is evidently blowing hard from nortlı-east, seud flying rapidly, and the outer iee, in aetive motion, pressing to the other shorc. Every effort was now made to eomplete my doeuments, tracings of eharts, ete., in order to forward them to Beeehey Island; and very harassing it proved, independent of eonstant ealls for other duties. At noon, barometer $29 \cdot 34^{\circ}$, temperature $12^{\circ}$, falling to $2^{\circ}$; at midnight the wind abated, teminating in ealm.

September 11.-At four this morning I was informed that the open water extended from Cape Osborn to the opposite coast. At five, Lientenant Osborn, assisted by a party from the 'Pioneer,' started, having reeeived despatches, ete., the preeeding evening. Commander Rieliards took the hands to the outer floe-edge, in the lope of blasting off the outer ice, whieh might also sliake the entire floe, and eause it to drift off with the tide. The day was beantifully fine, but this was found, under the present temperature, $15 \cdot 5^{\circ}$, witl bay ice forming and negativing every movement, quite beyond our powers: the mean depth of this immense floe-pieee being about seventecn feet, proved rather too mueh for our iee-saws, over' so great an extent. Mr. Allard, Master of the 'Pioneer,' aeeompanied Lieutenant Osborn to the floc-edge. 
launched him, and then visited Cape Osborn, from the summit of which he would have the opportunity of judging how far the open water prevailed below that position. Unfortmately, the present calm favours the formation of bay ice, which may compel the party to seek the in-shore floe. 'Tlic following, I perceive, are my remarks on this day :- "11th. Beautifully clcar, with a tcmperature of $15^{\circ}$ : and tantalizing indced is it to witness the opposite floe in rapid motion to the southward, when our position is such that little short of Nature's aid, in the form of a heavy grale, or of an off-shore set, can releasc us." Had such obstacles as these opposed us but a few weeks since, or cren now, with open water into which to float our fragments, we slould not lave despaired. But now ster'n Winter holds up his threatcning finger, and tells us in plain terms, "You have no business here with sueh puuy steam powcr." Query: what will he say to "Resolute, if he should triumphantly have 'Investigator' rcady at Melvillc Island beforc the castern barrier gives way, and but one steamer to tow both? I cannot forget the astonishment, in 1S5l, when I proposed the screw steam power in these regions. Increased power was denied me in 1552. Yet I liave becn made to feel its loss. Eventually the country may experience it by our detention this season. Moreover, no junior should in these matters tow his superior. The result in money remains to be totalled.

As to our crentual release this season I have my own impressious; they may be erroneous, but I still eling to crcry plausible reason on which hope can be based, preparatory to taking that most decisive step, "housing 
over" for winter. When that erent takes place, our men will exelaim, "Wcll, here we are for eertain."

As to any prospect of such a dilemma, I at present dissent. It is not my intention to remove anything out of the ship, but simply to sccure as much internal comfort as circumstances will permit; more, probably, if I crr not in my reasoning, than last season; but to be prepared to be moved at any moment that it may suit the caprice of Dame Nature. The grounds upon which I base my opinion are as follow. First. Notwithstanding opinion is against me, I consider this position unsafe, and that we are liable, even throughout the months of Oetober, November, and Deccmber, to be driven from henee. The American ressels were cntrapped in the pack, and eomparatively safe: they had no prospect of open water, it is true, but that is a danger, unless you are prepared with a port where shelter can be obtained. They were compclled to perform eertain gyratory movements during these months, reaching the neighbourhood of Bcechey Island about the 22nd of December!

Now all thesc same canses are visibly in operation, and it is only neeessary for "the turn of the wheel" to take a liking or involve in its chanees our frail barks, and off we travel on the tangent (if not crushed) into micl-chamnel. The sealing of the main pack to that connecting us is the act of a few lours. Who will venture then to dissolve the conncetion? I trust that it is scarccly nccessary for me to illustrate this by diagran; for the ice motion is so capricious, that direct, lateral, oblique, or rotary force will perform all we have to fear in a few hours, learing us to solve the problem in winter, 
by sounding through our fire-liole, over depths varying from six to six linudred fathoms, and making accurate charts of our motions by aid of the stars and chronometer's. T'lese are no idle whims or caprices. When that moment arrives, all I pray for is, that evcry man may be as well prepared to do his duty.

To sum up, I intend to be prepared to take, or be taken by, the iee, if it should so suit the will of Providence. Kceping in view that if such should happen before the cud of October, to endeavour to keep on this side, and if drifted as far as Becclicy Island, attempt to rcaeh Union Bay and there eut in, or possibly be saved the trouble by a nip.

Of my mode of lousing, when winter seals our posisition, I shall deal hereafter,-preparing at present the important ontlines, so far as our resources will admit.

September 12.--Late last crening, abont five, Mr. Allard returned, laving fallen in with Licntcnant Osborn, not far advanced. He had abandoned his boat, had placed the weights on my dog-sledge, destroyed it, and, by a note, suggested that a sledge and more provisions should be sent to him.

Dr. Lyall having volmtecred, - and considering him, for many good rensons, the nost effective aid as well as companion,-I again sent my own sledge, which earried the 'I Ianilton' last season; and if so laden, would then have sixteen persons to take her throngh her difficulties, with instructions "to accompany Lieutenant Osborn, if nccessary, the entire distance;" and keeping in vicw the peril incurred last scason, and the misfortune, but too apparent, of recent date, instructed linu to inform Liente- 
nant Osborn that no unccrtainty should exist, or that the boat must aeeompany lim. About eight P.M. Dr. Lyall started. 'This diminished our erew by twelve working hands.

I walked out to the floe-edge, nearly a mile, with Commander Rieliards; but it was very elear to me, that with the bay iee formed, it was uscless to attempt any further opcrations for cutting out. On my return I ascended the hill immediately above the ship, where I obtained the latitude as $75^{\circ} 32^{\prime} \mathrm{N}$., and a vcry elear view of the late spaee of open water, now skimmed over with bay ice. The heavy hummoeks, where we had pieked up the Halkett's boat, were still fast, water-washed, and free from floe! Had we fortunately held on there, we should possibly be now at Beechey Island. However, to the deerecs of fate we must submit cheerfully. Moving along the land-ridges I visited the deep ravine, where probably, at some remote pcriod, a river rolled impetuous into the sea. It liad ent its eliannels deeply, and in some instanees was bounded by abutting eliffs on either side, narrowing it to forty yards, and again expanding into five hundred; heavy rounded stoncs and radiated channcls affording the impression of a vast flow of water. It was aetive cven at this late season, and wherc wc frequently broke in, the stream was lunning beneath with a rivulet power; on the west also there was evidently a waterfall of some twclve feet. But there were very cxtensive inland lakes to warrant this eonstant escape of water, and their corrugated margins clearly indicated, although sheathed with six-inch iee, that their level was daily decrcasing. In one of these, attempts werc made 
to take fish by a small net of twenty feet span, and the bottom was seraped by the dredge, but without suecess: unfortmately, the seine ordered to be embarked in the 'Pioneer' was left behind, and thus all hopes of salmon, or large fish, frustrated. On my return I observed two of the officers bearing between them a hare they had killed, and inmediately where we then stood the traeks of several, or of the same animal, were noticed. One evidently had been pursued by a wolf, and a very smart ehase it must lave proved; but whieh might liave proved vietorious I was too far fatigued to follow up; the traees proved that the fore-paws of the wolf at each bound were never two inches belind those of the hare, and the measured leaps of several averaged six feet: cvidently in earnest!

A party which I sent to ereet marks on the neighbouring hills easterly also succeeded in killing a hare; so that we have some lopes of not being quite so badly off for game as at our last (but very seeure) wintcr-quarters. This set all the sportsmen agog, and eager for sport; and of this feeling I did not fail to take advantage, despatehing one party, as far as they pleased to go, northerly, in hopes of gaining some further information as to traces of the late boat party in that direction.

The issue of one of these exeursions, by our leading lumtsman, the Boatswain, was the diseovery of a spar, about a mile and a half inland, whieh, from the report, disturbing une about midnight, was " evidently the topgallantmast of a ship ;" the earpenter's mate, who was one of the party, being of opinion "that it was a worked spar, of about eight inches' diameter." Such a report from 
sueh authorities startled me not a little: one point however was not so elear to my imagination, - it was too far inland, and moreover in a hollow. Slecp howerer, for the remainder of the night, was destroyed.

On the 13th, after breakfast, I proceeded, taking with me the Boatswail and my boat's crew, with picks, erows, etc., to seareh for and bring in the diseovery. It was not without considerable diffieulty that it was re-diseovered; but I at onee pereeived that it was no sparr, and not plaeed there by human agency : it was the trunk and root of a tree, which had apparently grown there and flomished, but at what date who will venture to say? It is indeed one of the questions involved in the ehange of this elimate. As the men proeecled with the removal of the frozen elay surrounding the roots, which wcre eompletcly eemented, as it wcre, into the frozen mass, breaking off short like earthenware, they gradually developed the roots, as well as what appeared to be portions of leaves and other parts of the tree, which had become imbedded where they fell, and now were barcly distinguishable - at least not so muel as some impres. sions on eoal-to the easual observer. At the period that whales were thrown up and deposited on these mountains, the land grencrally convulsed, and also when a warmer elimate prevailed here, this trce possibly put forth its leaves and afforded shade from the sun: most fervently did I just now wish for its return. The stump was extraeted, and, with some of the surrounding soil, preserved for future examination. Two neighbouring mounds were also hug into, but they proved to be peat; -doubtless other stumps and vegetable matter, the only 
remaining traees of what might, at some distant period, have been a forest. All the surrounding eartl and tufts of grass indicated this spot to have been the bottom of some lake or marslı."

On my return, this evening, I land scarcely sighted the ship, when I diseovered that the 'Hamilton' and a tent had returned : at first I feared disaster, but it turned out to be the return of Dr. Lyall. Lieutenant Osborn,

* Throngh the kindness of Sir W. J. Ilooker and his son, Dr. Hooker, I am enabled to furnish the following intercsting remarks, which I think better placed here than in the Second Volume:-

"The piece of wood brought by Sir Edward Belcher from the shores of Wellington Channel belongs to a species of Pine, probably to the Pinus (Abies) alba, the most northern Conifer. This, the "White Sprrice," adrances as far north as the 65th parallel, and must be often floated down the great rivers of North America to the Polar Ocean.

"The structure of the woor of the spccinen brought home differs remarkably in its anatomical characters from that of any other Conifer with which I am acquainted. Each concentric ring of wood (or annual growth) consists of two zones of tissue; one, the onter, that towards the circumferenec, is broader, of a pale colour, and consists of ordinary tubes or fibres of wood, marked with the circular discs common to all Coniferce. These dises are usually opposite one another, when more than one row of them occur, in the dircetion of the length of the fibre, and, what is very unusual, present radiating lines from the central depression to the circumference.

"Second, the imner zone of cach annual ring of wood is narrower, of a dark colour, and formed of more slender moody fires, with thicker walls in proportion to their diameter. These tubes have few or no discs upon them, but are corered with spiral striæ, giring the appearance of each tube being formed of a tristed band.

"The above characters prevail in all parts of the wood, but are slightly moditied in different rings; thns the onter zone is broader in some than in others, the disc-bcaring fibres of the outer zone are sometimes faintly marked with spiral striæ, and the spirally-marked fibres of the inner zone sometimes bear discs.

"These appearauces suggest the aumulal recurrence of some special 
having been unable to earry out my intentions, had gone on with the sledge only.

September 14.-I had made arrangements this morning for the further eollcetion of the seraps dug up; but the iee made such ummistakable signs of general disturbanee, as to render it neeessary to elear away a safer position for the slip and tender within the grounded hummocks. The erews of botlı vessels were immediately at work, eutting doeks and clearing away the bay ice, now about nine inehes in thiekness. During this interval I was surprised by the boatswain bringing to me part of the furniture of a vessel, apparently the rumer of a sliding latel, and painted similarly to our own vessels or of yaelits; it was of teak, and I instantly connceted it with the former picee found by Mr. Grove, as part of the same ressel. The only reasonable idea whieh oeeurred to me (as it evidently did not belong to any Government ressel) was, that it might be part of 'The Mary,' which Commander Pullen had lamehed in order to visit Port Leopold, and she might have been nipped

cause that shall thus modify the first and last formed fibres of each year's deposit of wood, so that that first formed may differ in amount as well as in kind from that last formed, and the peculiar conditions of an Arctic climate appear to afford an adequate solution. The immer or first-formed zone must be regarded as imperfectly developed, bcing dcposited at a season when the functions of the plant are very intermitteutly excreised, and when a fow short hours of hot smnshine are daily succeeded by many of extreme cold. As the seasou advances, the sun's leat and light are continuous during the greater part of the twentyfour hours, and the newly-formed wood-fibres are hence more perfectly developed,-they are much larger, present no signs of strix, but are studded with dises of a more highly organized structure than are usual in the Natural Order to which this tree belongs."-J.J. D. Hоoker. 
in her attempt to reach me. An officer and party was despatched to make further scarel along the line of hummocks, but without success. About ninc P.M. the 'Assistance' was safely sceured within the hummocks, but the 'Pioneer' was yet unsafe.

END OF VOLUME I. 



\section{IIR. REEVE'S}

\section{LIS'T OF PUBLICATIONS.}

1.

Sir Edward Belcher, C.B.

The Last of the Arctic Voynges,

During the lears 1852-4, in H.M.S. Assistanee, under the command of Captain Sir I. Belcher, C.B., F.R.G.S.; with Notes on the Natural History, by Sil J. Richardsou, Professor Owen, Thomas Bell, J. W. Salter, and Lovell Reeve. With numerons coloured plates, charts, and wood-engravings.

$$
\text { Foyal svo, } 2 \text { rols., priec } 36 \text { s. }
$$

[Ready.

\section{Adam White, F.L.S.}

Popular History of Birds,

With 20 coloured plates. By ADAn WhITE, F.L.S.

$$
\because .
$$

\section{Dr. Daubeny, F.R.S.}

\section{Popular Geography of Plants;}

Or, a Botanieal Exeursion round the World. By F. M. C. Edited by Charles Daubexi, M.D., F.R.S., Professor of Botany in the University of Oxford. With 20 tinted landscapes in chromo-lithography.

$$
\text { Royal 16mo, price } 10 s .6 r l \text {. }
$$

[Ready.

\section{4.}

\section{Dr. Seemann, F.L.S.}

\section{Popular History of the Palms.}

With 20 tinted landseapes in chromo-lithography. By Dr. Bentuoun SEemany, F.I.S. 
5.

T. C. Archer.

A Series of Eight School Plant Diagrams, Illustrative of 'First Stcps to Economic Botany' by T. C. Archen, Esq. Published for the Department of Science and Art, Marlborough House.

Price 3s. 6d. coloured, 2s. plain, per Diagram.

6.

\section{T. C. Archer.}

\section{First Steps to Economic Botany;}

A Description of the Botanical and Commercial Claracters of the Chief Articles of Vegetable Origiu used for Food, Clothing, Tauning, Dyeing, Bnilding, Medicine, Perfumery, ete. For the use of Schools. By Thomas C. Arcier. With 20 plates. Published for the Department of Science and Art, Marlborough House.

Poyal $16 \mathrm{mo}$, priec 2s. 6el.

"An admirable and cheap little volume, abounding in goot illustrations of the plants that afford articles of food or applicable to purposes of manufacture. This should be on the table of every family, and its coutents familiar with all rising minds." ATLAs.

" $\Lambda$ s a cheap school book it is exceedingly well got up, and contains upwards of one hundred beautifully lithographed drawings, arranged on twenty plates; they represent varions useful plants and their products."

GUARDIAN.

\section{T. C. Archer.}

Popular Economic Botany;

Or, Deseription of the Botanical and Commercial Characters of the principal Articles of Vegetable Origin used for Food, Clothing, Tanning, Dyeing, Buildiug, Medicine, Perfumery, ete. By Thomas C. Arciner. With 20 coloured plates.

Poyal $16 \mathrm{mo}$, price $10 \mathrm{~s}$. $6 \mathrm{~d}$.

"Mr. Archer's volume, we are surprised to find, is the first popular book that has been deroted exclusively to the commercial products of the V'egetable Kinglom-of that which constitutes ninetwelfths of the whole commerce in raw joduce."

ExAMNER. 
S.

\section{Miss Catlow.}

\section{Popular Garden Botany;}

Containing a Faniliar and Technical Description of Hardy and Frame Plants, suitable for cultivation in the Garden. By Agses Catrow. With 20 coloured plates by W. Fitch.

$$
\text { Royal } 16 \mathrm{mo} \text {, price } 10 \mathrm{~s} .6 \mathrm{~d} \text {. }
$$

[Ready.

9.

\section{Thomas Moore, F.L.S.}

\section{Popular History of British Ferns}

and the Allied Plants; comprising the Club Mlosses, Pepperworts, and Horsetails. By Thomas Moore, F.L.S., Curator of the Botanic Garden, Chelsea. Second Edition. With 22 coloured plates by Fitch. Royal $16 \mathrm{mo}$, price $10 s$. $6 d$.

[Ready.

10.

\section{Miss Catlow.}

\section{Popular Field Botany;}

Containing a familiar and tcchnical Description of the Plants most common to the British Isles, adapted to the study of cither the Artificial or Natural System. By Agnes Catrow. Third Edition. In twelve chapters, cach bcing the botanical lesson for the month. With 20 coloured plates. 


\section{1}

Sir W. J. Hooker, F.L.S.

Curtis's Botanical Mayazine;

Comprising the Plants of the Royal Gardens of Kew, and of other Botanical Establishments in Great Britain, with suitahle Deseriptions. By Sir W. J. Hooker, F.L.S., Tirector of the Royal Gardens of Kew. In Numbers, each containing 6 coloured plates.

Royal svo. Published Montlly. Price 3s. Gr.

Vols. 1. to XI., price $12 \mathrm{~s}$. each.

12

Sir W. J. Hooker, F.R.S.

Joumal of Botany and Kew Miscellany;

Containing Origiual Papers by eminent Botanists, the Botanical News of the Month, Communications fom Botanical Travellers, Notices of New Books, etc. Editel by Sir W. J. НоокеR, F.R.S. With plates.

In Monthly Numbers, svo, price zs.

13.

Sir W. J. Hooker, F.R.S.

Icones Plantarum;

Or, Figures, with brief deseriptive Characters and Remarks, of new and rare Plants, selected from the Author's Herbarium. By Sir W. J. Ноокеr, F.P.S. New Series, Vol. V., with 100 plates.

Svo, price $31 s .6 d$. 
14.

\section{Notes and Notions on Created Things.}

First and Sccond Series. By the Author of 'E'pisodes of Insect Life.' With numerous wood-engravings.

12 mo, price 5 s. each Series.

"We cannot imagine a book that would take a deeper hold of the imagination." ATHeneus.

15.

Dr. Hooker, F.R.S.

The Rhododendrons of Sikkim-Himalaya;

Being an Aecout of the Rhododendrons recently diseovered in the Mountains of Eastern Himalaya. By J. D. НоокеR, II.D., F.R.S. With 30 plates ly W. Fitcli.

Imperial folion, price $\mathfrak{e} 3,1$ lis

16.

Dr. Hooker, F.R.S.

Illustrations of Sikkim-Himalayan Plants,

Chiefly selected from Drawings malc in Sikkim under the superintendence of the late J. F. Catheart, Esy., Bengal Civil Service. The Botanical Descriptions aud Analyses by J. D. Hooker, M.D., F.R.S. With 't colourch plates by Fitch, and an illuminated title-page.

Folio, price £.5. 5s. 
17.

Professor Edward Forbes, F.R.S.

Literary Papers on Scientific Subjects.

By the late Professor Eowarn Forbes, F.R.S. Selected from his

Writings in the 'Literary Gazette.' With a Portrait and Memoir.

Small Sro, price $6 s$.

"This reprint of reviews forms a charming book of miscellaneous essays. The criticism is genial, sensible, comprehensive, and compact. It is not common to find eminent scientific men graceful, easy, and piquant littérateurs; but whenever such a union of claims to public favour is manifested, it should meet with honour due. But, besides being a scientific professor, a critic, and littcrateur, the late Edward Forbes was before all things a man-genial, sympatletic, brave, and true-a thorough good fellow, as good a fellow as he was a naturalist. The reader cannot do better than possess himself of this amusing and instructive volume, if he have a liking for science without solemnity, criticism without ill-1 ature, and with knowledge of the subject; pleasant talk with a definite result, and a sense of the comic without the vulgar error of turning all things to a jest."

GLOBE.

18.

Sir W. J. Hooker, F.R.S.

The Victoria Regia.

By Sir W. J. НоокеR, F.R.S. With four coloured plates by Fitch. Elephant folio, price 218 .

19.

Dr. Badham.

The Esculent Funguses of England;

Containing an Aecount of their Classieal History, Uses, Charneters, Development, Structure, Nutritious Properties, Modes of Cooking, ete. By the Rev. Dr. BadHam. With 20 coloured plates.

Supcr-royal 8vo, price $21 s$. 


\section{Dr. Landsborough, A.L.S.}

\section{Popular History of British Seaveeds;}

Comprising their Structure, Frnetification, Specific Characters, Arrangement, and Gencral Distribntion, with Notices of some of the Fresh-water Algae. By the Rev. D. LAvdsborovgu, A.L.S. Second Edition. With 20 coloured plates by Fitch.

Royal $16 \mathrm{mo}$, price $10 \mathrm{~s} .6 \mathrm{~d}$.

"The book is as well executed as it is well timed. The descriptions are scientific as well as popular, and the plates are clear and explicit. It is a worthy sea-side com. panion-a handbook for evcry resident on the sea-shore." Econoust.

Professor Harvey, M.R.I.A.

\section{Playcologia Britannica;}

Or, History of the British Seaweeds ; containing colourcd Figures and Descriptions of all the Species of Alga inhabiting the Shores of the British Islands. By William Henry Harver, M.D., M.R.I.A., Keeper of the Herbarium of the University of Dublin, and Professor of Botany to the Dublin Society. With 360 plates.

In threc vols. royal 8vo, arranged in the order of publication . . . . . . . .

In four vols. royal svo, arranged systematically according to the Synopsis

A few Copies have been printed on lurge paper.

"The drawings are beaurifully executed by the author himself on stone, the dissec. tions carefully prepared, and the whole account of the species drawn up in such a way as cannot fail to be instructive, even to those who are well acquainted with the subject. The greater part of our more common Algæ have nevel been illustrated in a manner agreeable to the present stitc of $A \operatorname{lgology} . "$

GARDENERS' C'HRONIClE. 


\section{$\therefore:$.}

\section{Professor Harvey, M.R.I.A.}

\section{Nereis Australis;}

Or, Illustrations of the Algae of the Sontlicm Ocean. Being Figures and Descriptions of Marine Plants collected on the Shores of the Cape of Good Hope, the extra-tropical Australian Colonies, Tasmania, New Zenland, and the Antaretic Regions. By Professor HArver, M.D., M.R.I.A. Two Parts, each containing 25 coloured plates.

Imperial svo, price $\mathfrak{s} 1.1 s$.

$$
23 .
$$

\section{J. Sanders.}

\section{Treatise on the Culture of the Vine,}

As well nnder Glass as in the Open Air. By J. SAxpers. With 9 plates.

$$
\text { siv. price } 5 \text {. }
$$

"We have examined. with no common interest, the work before us ; for it will be stiange indeel if a wan who wan ast so skilfully as Mr. Sanders should be unable to mier alvice of a corresponding value. We have not been disappointed. Mr. Sanders's directions are as plain as words con moke thom, and. we will add, as judicious as his Iong experience had led us to expeet." Cisrdeners' Chronicle.

\section{4.}

Dr. Seemann, N.L.S.

\section{Botany of the Voyjage of H.MLS. Herald,}

Under the commaul of Captain Kellett, R.N., C.B., during the years 1845-51. By 1r. Bermiold Semani, F.L.S. Published under the autlority of the Lords commissioners of the Admiralty. In Parts, each with 10 jlates. 
25 .

Di. Hooker, F.R.S.

\section{Flora of New Zealand.}

by Joseph Datton Hooker, M.D., F.R.S., etc. In 2 volumes With 130 Plates.

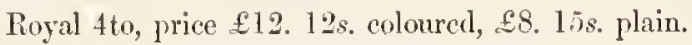

"The work is written in good plain English, with a view to the conveniency of colonists, but without on that account being rendered in the smallest degree unscientific; quite the contrary. Let us add, that the beautiful execution of the work renders it a library-book, even for those who are not interested about natural history."

Gardeners' Chronicle.

26.

\section{Dr. Hooker, F.R.S.}

\section{Flora Antarctica;}

Or, Botany of the Antarctic Voyage of H.M. Discovery Ships Erebus and Terror, in the years 1839-43, under the command of Captain Sir J. C. Ross, F.R.S. By Dr. Hooker, F.R.S. Published under the anthority of the Lords Commissioners of the Admiralty. With 200 plates.

2 rols. royal 4to, price $£ 10$. 15s. coloured, $£ 7.10 s$. plain.

"The descriptions of the plants in this work are carefully drawn up, and much interesting matter, critical, explanatory, and historical, is added in the form of notes. The drawings of the plants are admirably executed by Mr. Fitch; and we know of no productions from his pencil, or, in fact, any botanical illustrations at all, that are superior in faithful representation and botanical correctness."

ATHENAUM.

27

Dr. Hooker, F.R.S.

Chyptogamia Antarctica;

Or, Cryptogamic Botany of the Antarctic Voyage of H.M. Ships

Erebus and Terror. Issued scparatcly. With 72 plates.

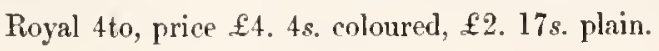




\section{A Popular History of British Mosses,}

Com!rising a General Account of their Structure, Fructification, Arrangement, and General Distribution. By R. M. STARK, Esq. With 20 colvured plates.

[ Just published.

\section{Royal $16 \mathrm{~m} n$, price $10 \mathrm{~s} .6 d$.}

"Mr. Stark has given as full and instructive an account of our wild MLsses as can well be desired. It is founded avowedly upon the long labours of Gir W illiam Hooker in the same direction, and this alone guarantees the soundness of the author's systematic views. All the genera and species of 'Mloss,' as that term is understood hy hotanists, are clearly hut succinctly described in the English language; and to aid the learner in understanding the subject, we find twenty coloured plates admirably executed hy Mr. Fitch. When we acld that the work has a good index, the reader will require no further assurance that it deserves to he strongly recommended." Gardeners' Chronicle.

" 'Popular" Britisb Mosses' is the hest book we have seen upon the subject. The plates are exquisite, and do justice to the grace and delicacy of the originals."

\section{Guardian.}

\section{9.}

\section{Miss Roberts.}

\section{Voices from the Woodlands;}

Descriptive of Forest Trees, Ferns, Mosses, and Lichens. By Mary Roвerts. With 20 coloured plates by Fitch.

\section{lioyal $16 \mathrm{mo}$, , nice $10 \mathrm{~s}$. fid.}

"The fair authoress of this pretty volume lias slown more than the usual good taste of her sex in the selection of ber mode of conveying to the young interesting instruction upon pleasing topics. She bids them join in a ramble through the sylvan wilds; and at her command the fragile lichen, the gnarled oak, the towering beech, the graceful chestnut, and the waving poplar, discuurse eloquently, and tell their respective histories and uses."

BRITANNIA.

30.

\section{Joseph Woods, F.L.S.}

\section{The Tourist's Flora;}

A Descriptive Catalogue of the Flowering Plants and Ferns of the British Islands, France, Germany, Switzerland, and Italy. By Joserн Woods, F.L.S. With a plate. 


\section{Mrs. Hussey.}

\section{Illustrations of British Mycology;}

Or, Figures and Descriptions of the Funguses of interest and novelty indigenous to Britain. By Mrs. Hussey.

Royal 4to. First Scries, 90 coloured plates, price $\mathfrak{£} 7.12 s .6 d$.; Second Series, 48 plates, price $\mathfrak{E} 4$. $2 s .6 d$.

"This is an elegant and interesting book: it would bc an ornament to the drawingroom tible; but it must not, therefore, be supposed that the value of the work is not intrinsic, for a great deal of new and valuable matter accompanıes the plates, which are not fancy sketches, but so individualized and life-like, that to mistake any species seems impossible. The accessories of each are significant of site, soil, and season of growth, so that the botanist may study with advantage what the artist may inspect with admiration."

Monning Post.

32.

\section{Sir W. J. Hooker, F.R.S.}

\section{A Century of Orchidaceous Plants.}

The Plates selected from Curtis's Botanical Magazine. The Descriptions re-written by Sir W. J. Hooker, F.R.S., Director of the Royal Gardens of Kew; with Iutroduction, and Instructions for their Culture, by Johx Charles Lyoss. 100 colnured plates.

Royal 4 to, price $£ 5.5 s$.

"In the exquisite illustrations to this splendid volume, full justice has been rendered to the oddly formed and often brilliantly coloured flowers of this curious and interesting trihe of plants." Westminster and Foreign QTarterly Reriew. 
33.

\section{Henry Sowerby.}

\section{Popular Mineralogy;}

Comprising a familiar Account of Minerals and their Uses. By HeNry Sowerbr. With 20 coloured plates.

$$
\text { Royal } 16 \mathrm{mo} \text {, price } 10 s .6 d \text {. }
$$

"Mr. Sowerby has endeavoured to throw around his subject every attraction. His work is fully and carefully illustrated with coloured plates." SPEcraton.

\section{4.}

\section{Adam White, F.L.S.}

\section{Popular History of Mammalia;}

Containing a familiar Account of their Classification and Habits. By Aday White, F.L.S., of the British Museum. With sixteen coloured plates of Quadrupeds, by B. Waterhou'se Hawkins, F.L.S.

$$
\text { Thoyal } 16 \mathrm{mo} \text {, price } 10 s .6 d \text {. }
$$

"The present increase of our stores of anecdotal matter respecting every kind of animal has been used with much tact by Mr. White, who has a terse chatty way of putting down his reflections, mingled with easy familiarity, which every one accustomed daily to zoological pursuits is sure to attain. The book is profusely illustrated."

ATLAS.

\section{5.}

Francis Walker, F.L.S., and H. T. Stainton.

\section{Insecta Britannica;}

Vols. I. and II., Diptera. By Francis WaLker, F.L.S. With 20 plates. Vol. III., Lepidoptera: Tineina. By H. T. Stainton. With 10 plates.

$$
\text { Rro, price 25s, each. }
$$


36.

\section{Miss M. E. Catlow.}

\section{Popular Britisle Entomology;}

Containing a familiar and teclnical Description of the Inseets most eommon to the British Isles. By Maria E. Catlow. Second Edition. In twelve chapters, each being the entomological lesson for the month. With 16 coloured plates.

Royal $16 \mathrm{mo}$, price $10 \mathrm{~s} .6 \mathrm{~d}$.

"Judiciously executed, with excellent figures of the commoner species, for the use of young beginners." AdDress of Presidext of the Extomological Society.

"Miss Catlow's "Popular British Entonology" contains an introrluctory chapter or two on classification, which are followed by brief generic and specific descriptions in English of above 200 of the commoner British species, together with accnrate figures of about 70 of those described; and will be quite a treasure to any one just commencing the study of this fasciuating science."

Westminster and Foreton Quartertit Review.

$3 \gamma$

John Curtis, F.L.S.

\section{Curtis's British Entomology;}

Being Illnstrations and Deseriptions of the Genera of Inseets found in Great Britain and Ireland, containing coloured figures, from nature, of the most rare and beantiful species, and, in many instanees, of the plants upon which they are found.

Commenced in 1824 and completed in 1840, in 193 numbers, forming 16 volnmes, price $£ 43.16 s$. Now offered to Subseribers, new aud in the best condition, with 770 coloured plates, at $\mathfrak{E} 21$.

Tie-issned also in Montlly Parts, price $3 s .6 d$.

Vols. I. to V. of the lie-issne now realy, price $42 s$. each.

“Vous savez qu'à l'égard d'un grand nombre d'espèces, leur détermination réclame le secours de figures. Il est donc de mon devoir de vous imeliquer les livres où vous trouverez les meilleures. Celui de M. Curtis, sur les genres d'insectes indigènes de l'Angleterre, me parait avoir atteint l"ultimatum de la perfection."-LaTrenLtE.

" V. John Curtis, naturaliate Anglais, a commencé la publication d'un fenera iconographique rles genres d'insectes et re plantes propres à la Grande Bretagne. Leurs caractères y sont représentés avec la plus grande fidólité."-Cuvier. 
30.

G. B. Sowerby, F.L.S.

\section{Popular British Conchology;}

Containing a familiar History of the Molluses and Shells inhabiting the British Isles. By G. B. Sowerby, F.L.S. With 20 coloured plates.

[ Just published.

Royal $16 \mathrm{mo}$, price $10 s .6 d$.

"Mr. G. B. Sowerby maintains the character of his father and grandfather as a naturalist, and has here produced a very instructive volume as an introduction to the study of shells. This work belongs to Mr. Reeve's illustrated series on Popular Natural History, and is a worthy companion to some of the latter volumes, of the value and interest of which we have spoken when they were published. It will he seen by the title that this work is confined to British shells. It will be found a most convenient handbook at the sea-side, as all the more common shells are not only described, but illustrated. It will serve as an admirable introduction to the great work on 'British Mollusca,' by the late Edward Forbes and Mr. Hanley."

ATHENEUM.

39.

Lovell Reeve, F.L.S.

Elements of Conchology;

Comprising the Physiological History of Shells and their Mollnseous Inhabitants; their Structure, Geographical Distribution, Habits, Characters, Affinities, Arrangement, anel Enumeration of Spccies. By Lovel Reeve, F.L.S. Parts 1 to 10, with 50 coloured plates.

Royal 8vo, price 3.6. 6ach.

"The work before us is designed to promote a more philosophical spirit of inquiry into the nature and origin of Shells." PCCLEsLastical Review.

40 .

Lovell Reeve, F.L.S.

Conchologia Systematica;

Or, Complete System of Conchology; in which the Lejades and Conchiferous Mollusca are described and classified according to their Natural Organization and Habits. By Lovelu Reeve, F.L.S. Illustrated with 300 plates of upwards of 1500 figures of Shells.

Two vols. tto, price $£ 10$ coloured, $\mathfrak{E} 6$ plain. 


\section{1. \\ Lovell Reeve, F.L.S. \\ Conchologia Iconica;}

Or. Figures and Descriptions of the Shells of Molluscous Animals. with Critical Remarks on their Synonyms, Affinities, and Circumstances of Habitation. By Lovell Reeve, F.L.S. Published Monthly in Parts, demy 4to, each containing eight plates, price $10 \mathrm{~s}$.

\section{In Monographs:}

\begin{tabular}{|c|c|c|c|c|c|c|}
\hline & $\pm^{2}$ & & $d$ & & & \\
\hline$\Lambda$ сHАTNA & 1 & 9 & 0 & Lieina. & (1) 14 & \\
\hline ACHATIXELLA ..... & 0 & S & 0 & LUTRARIA & 0 & \\
\hline AMPHIDESMA ... & 0 & 9 & 0 & MACTRA. & 1 & \\
\hline ARCA .............. & 1 & 1 & 6 & MANGELIA & 010 & \\
\hline ARTEMIS ......................... & 0 & 13 & 0 & MEsalia and Eglisia............ & 0 & \\
\hline Becciscat & 0 & 18 & 0 & 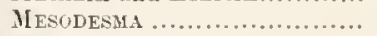 & 05 & \\
\hline 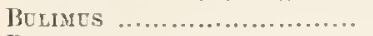 & 5 & 12 & 0 & MLtтRa ............................ & 210 & \\
\hline 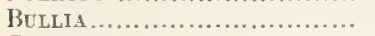 & 0 & 5 & 6 & MIONOCEROS ............................ & $0 \quad 5$ & \\
\hline 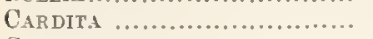 & 01 & 11 & 6 & Mrkex & 25 & \\
\hline CARDIUSI ......................... & 1 & S & 0 & IYADORA ........................ & 01 & \\
\hline 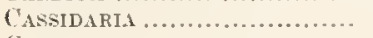 & 0 & 1 & 6 & NASSA $\ldots \ldots \ldots \ldots$ & 117 & \\
\hline ASsIS . . . . ...................... & 01 & 15 & 6 & N.ıтісы........................... & 118 & \\
\hline HAMA ....................... & 01 & 11 & 6 & 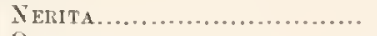 & 14 & \\
\hline HITON ........................... & 2 & 2 & 0 & Oliva $\ldots \ldots \ldots \ldots \ldots \ldots \ldots \ldots$ & 118 & \\
\hline 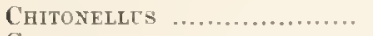 & 0 & 1 & 6 & ONISCIA $\ldots \ldots \ldots \ldots$ & 0 & \\
\hline oves ...................... & 3 & 0 & 0 & PaLedomes ....................... & 0 & \\
\hline ORBCLA ................. & 0 & 6 & 6 & 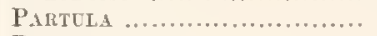 & 05 & \\
\hline 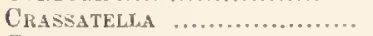 & 0 & \pm & ก & 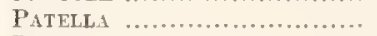 & 213 & \\
\hline 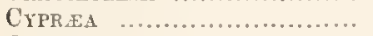 & 1 & 14 & 0 & 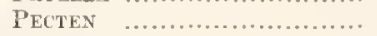 & 24 & \\
\hline 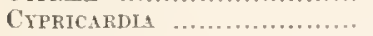 & 0 & 3 & 0 & 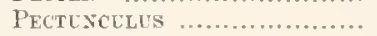 & 011 & \\
\hline DELPHINTLA & 0 & 6 & 6 & PHORES & 01 & \\
\hline 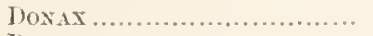 & 0 & 12 & (1) & PLELRotoma ................... & 210 & \\
\hline OLICX & 0 & 10 & 6 & Pterocera ........................ & 08 & \\
\hline 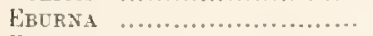 & 0 & 1 & 0 & PURPURA . . . . . . . . . . . . . . & 017 & \\
\hline 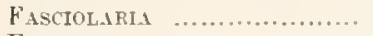 & 0 & 9 & u & 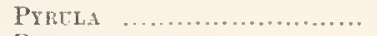 & 011 & \\
\hline 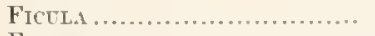 & 0 & 1 & 6 & RANELLA . . ... ........... & 010 & \\
\hline 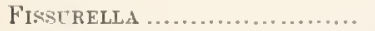 & 1 & 0 & 6 & lícinola ........................... & 0 & \\
\hline 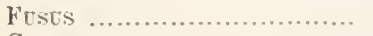 & 1 & h & 6 & RUSTELLARIA ............... & 0 & \\
\hline GLACCONOME & 0 & 1 & 6 & 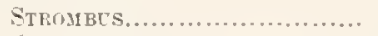 & 1 & \\
\hline HALTOTIS. & 1 & 1 & 0 & STRUTHIOLARIA .............. & 01 & \\
\hline ........ & 0 & 5 & 6 & 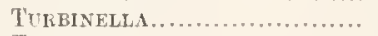 & 017 & \\
\hline HeLtx $\ldots .$. & 13 & 5 & 0 & TON n........................ & 15 & \\
\hline HEMIPECTEN ....... & 0 & 1 & 6 & (no & 017 & \\
\hline NTTES ......................... & 0 & 1 & 6 & RRITELL. . . . . . . . . . . . . . . . . . & 014 & \\
\hline 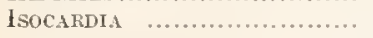 & 0 & 1 & 6 & VoLUTA & 18 & \\
\hline
\end{tabular}

"This great work is intended to embrace a complete description and illustration of the shells of molluscous animals; and so far as we have seen, it is not such as to disappoint the large expectations that have been formed respecting it. The figures of the shclls are all of full size: in the descriptions a careful analysis is given of the labours of others: and the author has apparently spared no pains to make the work a standard authority on the subject of which it treats."

ATHFN FIM. 


\section{Miss Roberts.}

\section{Popular History of the Mollusca;}

Comprising a familiar Account of their Classification, Instincts, and Habits, and of the Growth and Distinguishing Characters of their Shells. By Marr Roberts. With 18 coloured plates by Wing.

Royal $16 \mathrm{mo}$, price $10 \mathrm{~s} .6 \mathrm{~d}$.

"The authoress is alrealy favourably known to British naturalists by her 'Conchologist's Companion,' and by other works on natural history. We expected to find in it a useful and entertaining volume. We have not been disappointed. . . The work is illustrated with eighteen plates, beautifully coloured-in most instances affording a view of the structure of the animal." ATHEN EUM.

43.

P. H. Gosse.

\section{Popular British Ornithology;}

Containing a familiar and technical Description of the Birds of the British Isles. By P. H. Gosse. Second Edition. In twelve chapters, each being the ornithological lesson for the month. With 20 coloured plates.

Royal $16 \mathrm{mo}$, price $10 \mathrm{~s} .6 d$.

"To render the subject of ornithology clear, and its study attractive, has been the great aim of the author of this beautiful little volume. . . . It is embellished by upwards of seventy figures of British birds beautifully coloured." Morning Herald. 
44.

\section{Miss Catlow.}

\section{Drops of Water;}

Their marvellous and beautiful Inhabitants displayed by the Microscope. By Agnes Catcow. With 4 coloured plates.

Square 12 mo, price 7 s. 6d.

"An elegant little book, both in the getting up and its literature. . . The text is accompanied by coloured plates that exhibit the most remarkable creatures of the watery world." SPEctator.

"Of the manner in which this work is executed, we can say that, like Miss Catlow's previous productions on natural history, it displays an accurate acquaintance with the subject, and a keen delight in the contemplation of the objects to which it is devoted. As far as the living beings which inhabit "Mrops of Water" are concerned, we know of no better introluction to the nse of the microscope than the present volume."

ATHEN LUM.

1.5.

Dr. Landsborough, A.L.S.

\section{Popular History of British Zooplyytes;}

By the Ricv. D. LAvosmonocan, A.L.S., Member of the Wernerian Society of Ediuburgh. With 20 columrel plates.

lioyal $16 \mathrm{mo}$, price $10 \mathrm{~s} .6 \mathrm{~d}$.

"This work constitutes one of the popular series of scientific treatises which, from the simplicity of their style, and the artistic excellence and correctness of their numerous illustrations, has acquired a celebrity beyond that of any other series of noderu cheap works. With this manual of Zoopliytes, and that upon Seaweeds, by the same author, the sturlent can ramble along the sea-shores, and glean knowledge from every heap of tangled weed that lies in his pathway." Liverfool StANDARD. 
46.

\section{Dr. Thomson, F.L.S. \\ Western Himalaya and Tibet;}

The Narrative of a Journey through the Mlountains of Northern India during the ycars 1847 and 1848. By Thomas Thomson, M.D., Assistant-Surgeon, Bengal Army. With Tinted Lithograpls and a Map by Petermann.

$$
\text { Sro, price } 158 .
$$

"Few more valuable volumes of travels than this by Dr. Thomson have been for a long time past published. Long after the interest which its novelty will create shall have passed away, it will be a standard book of reference, on account of thic valuable facts which it contains, and of the spirit of sound observation in which it is written."

ATHEN EUM.

\section{$4 \%$}

\section{Dr. Gardner, F.L.S.}

\section{I'rarels in the Interior of Brazil,}

Prineipally through the Northern Provinces and the Gold and Dianond Districts, during the years 1836-41. By George Gardner, M.D., F.L.S. Second Edition. With Plate and Map.

$$
\text { sivo, price } 12 s .
$$

"When camping out on the mountain-top or in the wilderness; roughing it in bis long journey through the interior; observing the very singular mode of life there presented to bis notice; describing the curious characters that fell under his observation, tbe arts or substitutes for arts of the people, and the natural productions of the country, these travels are full of attraction. 'The hook, like the country it describes, is full of new matter."

SPECTATOR.

"This volume is from the pen of an ahle naturalist, whose heart is in his vccupation.

Some of the regions he visited lave selom been trodden by Luropeans-never by Englishmen: so that his o.sserations derive value from the novelty of the unatter to which they relatc."

$\triangle T H E N$ EUM. 
48.

\section{A. R. Wallace.}

\section{Trarels on the Amazon and Rio Negro,}

With an Account of the Native Tribes, and Observations on the Climate, Geology, and Natural History of the Amazon Valley. By Alfreo R. Wallace, Esq. With Remarks on the Vocabularies of Amazouian Languages, by R. G. LAtham, M.D., F.R.S. With 6 plates and mapk.

$$
\text { Joyal sro, } 18 .
$$

"Mr. Wallace has given us a most lively and interestimg picture of the glories of the magnificent river. Venezuela, Colonbia, Ecuador, Peru, Bolivia, and Brazil, six mighty States, spreading over an area far more extensive than Europe herself, contribute their aid in forming the flood up which he toiled. For twenty-eight days consecutively he breasted the stream of the Arrazon. . . He enters, with all the zest of a naturalist, into the history of the living things which $\mathrm{fly}$, run, or creep over the surface of the country. His sketches of the natives, their appearance, hahits, and disposition, are quite original."

BRITANNIA.

"In the novelty of the scenery aid mamnes; in the truthful, alheit somewhat literal, picture of what the traveller saw and felt : in the ciuet eanestness by which obstacles were surmonnted by 'Tilleyrand's farourite rule of waiting ; and in the patience with which sickness, suffering, and privations were submitted to, "Travels on the Aunzon and lio Negro" remind us of the simplicity of the old voyagers."

49.

\section{Dr. Seemann, F.L.S.}

\section{Circumnavigation of the Globe;}

Being the Narrative of the Voyage of H.M.S. Herald, under the com mand of Captin Kellett, R.N., C.B., during the years 1845-51. By Berthold Seemaxx, F.L.S., Naturalist of the Expedition. With Tinted Lithograplss and a Map by Petermanı.

2 vols. Sro, price $21 s$.

"Witl extensive knowledge in geography and its cognate sciences, Mr. Seemanu possesses a close and soher but vivid style, which expresses his ideas not only with clearness, but animation."

SPECTATOR.

"Mr. Seemann is always a lively and agreeable companion, and has the merit of directing the attention of the general reader to applied natural history rather than to questions only interesting to the student of pure science." GaRDExERs' Chrosicle. 
50 .

\section{J. Beete Jukes, F.G.S.}

\section{Popular Plysical Geology.}

By J. BeEte Jukes, F.C.S., President of the Geological Society of Dublin. With 20 Landscape Views of Geological Scenery in DoulleTinted Lithography.

lioyal 1 timo, price $10 s$. Gid.

"Mr. Jukes's 'Popular Physical Geology' is peeuliarly remarkalle for the skilful treatinent of his subject. The established facts and prineiples of geology are not only presented with freshness, but so elearly enforced and illustrated as to impress the mind of the student, while he is stimulater to olservation by the fucility with which he is shown that observation can lie made."

"The illustrations to the work are of the most aceurate as well as beautiful character, combining the skill of the artist with the knowlerlge of the geologist." OBsErvEr.

\section{1 .}

\section{H. J. Smith.}

\section{Parlis and Pleasure Grounds;}

Or, l'ractical Notes on Country Lesidences, Villas, Pnblic l'arks, and Gardens. By Chakles H. J. Sinti, Jandseape Gardener.

('rown Svo, price $6 s$.

"Mr. Sinith, who is a landscape gardener and garden al"chitect of great experience, hats worked ont his design with ability and judgment."

Globe.

"The charater of this publicntion is altogether plactical, from the opening hints npon the honse and oftices, to the closing directions about the arboretum and the pinetum."

SPECTATOR. 
52.

\section{Chandos Wren Hoskyns.}

\section{T'alpa; or, the Chronicles of a Clay Firm.}

An Agricultural Fragment. By Chandos Wrex Hoskrss. New and Cheaper Edition, with Frontispiece by George Cruikshank.

Fep. Svo, price 3s. frel.

"The writer handles this subject in such a masterly manner-his style is so piquaut, as well as forcible, so scholarly, yet so racy-his wit and his wisdon are so skilfully blended-lie has so cleverly worked out his motto. Ridentem dicere res"um, by telling the trith laughingly - that the reader finds himself irresistibly carried along, and he and the book part not company until he has made hinself master of the tale that he lias to unfold." LETCESTERSHIRE MIFRCCRT.

"This is a rare little volume. We don't know which to almire most, the author's humour or his risdom. He has set hiruself the task of illustrating, in an agreeable manner, the evils of eustom, prejndice, and feudalisu, as they exist among agriculturists. It will create iunch laughter among the merry, and convey many a lesson to the tiller of the soil. There are some very capital illustrations, tuo, enbellishing the volume." ERA.

"Cleverly written in a vein of pleasantry, the work perseveringly uproots the prejud:ce of the past, and demonstrates that scientific knowledge is an inportant element in successful tillage."

JINCOLA JERCURY.

$5: 3$.

Piscarius.

\section{The Artificial Production of Fish.}

Py Piscarios. Thiml Edition.

Price Is.

"The object of this little hook is to make known the means by which fish of all descriptions nay be multiplied in rivers to an almost mealculable extent. . . . This principle of increase Piscarius has carried out hy argument and experiment in his little treatise, which, we think, is wortlyy the attention of the legislator, the country gentleman, and the clergyman; for it shows how an immense addition may he mate to the preople's ford with scarcely any expense."

ER.1. 
54.

Arthur Adams, F.L.S.

\section{Zoology of the Voyage of H.M.S. Samarany,}

Under the command of Captain Sir Edward Belcher, C.B., F.R.A.S., during the years 1843-46. Edited by Arthur Adams, F.L.S.

The Vertebrata, with 8 plates, by Joln Edward Gray, F.R.S.; the Fishes, with 10 plates, by Sir John Richardson, F.R.S. ; the Mollusca, with 24 plates, by Arthur Adams, F.L.S., and Lovell Reeve, F.L.S.; the Crustacea, with 1.3 plates, by Arthur Adams, F.T.S., and Adam White, F.L.S.

Royal 4to, price $£ 3.10$ s. coloured.

55.

Sir John Richardson.

\section{Zoology of the Voyage of H.M.S. Herald,}

Under the command of Captain Kellett, R.N., during the years 184518.51. By Sir J. Richardsox. Edited by Professor Edward Forbes, F.R.S. Pnblished under the anthority of the Lords Commissioners of the Admiralty.

Part I. Fossil Mammals, 15 donble plates.

Royal t to, $21 s$.

Part II. Fossil Mammals, 10 plates.

rioyal to, 10s. Grt.

Part III. Reptiles and Fish, 10 plates.

Ringal 4to; 10 s. $6 d$. 
56 .

\section{Miss M. E. Catlow.}

\section{Popular Scripture Zoology;}

Containing a familiar History of the Animals mentioned in the Bible.

By Maria E. Catrow. With 16 coloured plates.

lioyal $16 \mathrm{mo}$, price $10 s .6 d$.

"It contains a short and clear account of the animals mentioned in the Bible, classed according to their geuera, and illustrated by a number of well-executed and characteristic coloured plates. It is a seasonable addition to a very nice set of books."

GUARDIAN.

"Miss Catlow's abilities as a naturalist, and her tact in popularizing any subject sle undertakes, are too well known to need reiteration on this occasion."

Notes IND QUerIES.

57

R. J. Mann.

\section{The Planetary and Stellar Universe.}

A Series of Lectures. By Robert James Maxn.

$12 \mathrm{mo}$, price $5 s$.

"A brief abstract of the discoveries of Newton, clearly explained and elegantly illustrated."

Westuinster and Foreign Quarterly Review.

58.

\section{H. Edwards, LL.D.}

\section{Illustrations of the Wisdom and Benerolence} of the Deity, as manifested in Nature. By H. Eowaros, LL.D.

$16 \mathrm{mo}$, price $2 s$. $6 d$.

"A little excursion in the track of Paley and the broad road of the Bridgewater Trea. tises. Animals, Atmosphere, Organic Matter, Light, and Electricity are the natural elements out of which the author deduces his pious lessons, leading to a First Cause in wonder, admiration, and worship."

Literary GazetTe. 


\section{PREPARING FOR PUBLICATION.}

Popular British Archacology.

By the Rev. C. Bouteli, M.A.

Flora Tremanica:

A History of the Plants of Van Diemen's Land ; being the concluding portion of the 'Floru Antaretica.' By Dr. J. D. Hooker, F.IR.S.

[Part I. now ready.

Insecta Britrmica.

Vol. IV. Diptera, Vol. III. By Francis Walier, F.L.S.

Popular Garden Botany.

Vol. II., Grecnhouse Plants. By Agnes Catlow.

Popular History of British Fossits.

By Professor Wrvilie Thomsox.

Popular IIistory of British Fishes.

By the Rev. J. Loxgmetr.

Popular History of British Lichens.

By Dr. Lat'der Lindsey.

Popular IIistory of British Crustacea.

BY ADAM White, F.L.S.

Popular Mistory of the Water Tivarium.

By G. B. Sow ERry, F.L.S. 


$$
74555
$$





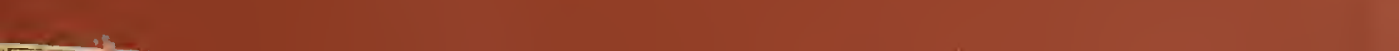



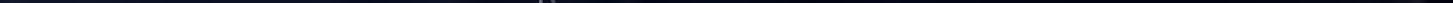